\title{
EFEITO DE MANEJO EM ALGUNS ATRIBUTOS DE UM LATOSSOLO ROXO SOB CERRADO E NAS CARACTERISTICAS PRODUTIVAS DE MILHO, SOJA, ARROZ E FEIJÃO, APÓS OITO ANOS DE PLANTIO DIRETO
}

\author{
JOÃO KLUTHCOUSKI \\ Engenheiro Agrônomo
}

Orientador: Prof. Dr. ANTÔNIO LUIZ FANCELLI

Tese apresentada à Escola Superior de Agricultura "Luiz de Queiroz", Universidade de São Paulo, para obtenção do título de Doutor em Agronomia. Área de Concentração: Fitotecnia.

Piracicaba

Estado de São Paulo - Brasil

Setembro - 1998 


\section{ERRATA}

Tese Doutorado "Efeito de manejo em alguns atributos de um Latossolo Roxo sob Cerrado e nas características produtivas de milho, soja, arroz e feijão, após oito anos de plantio direto.

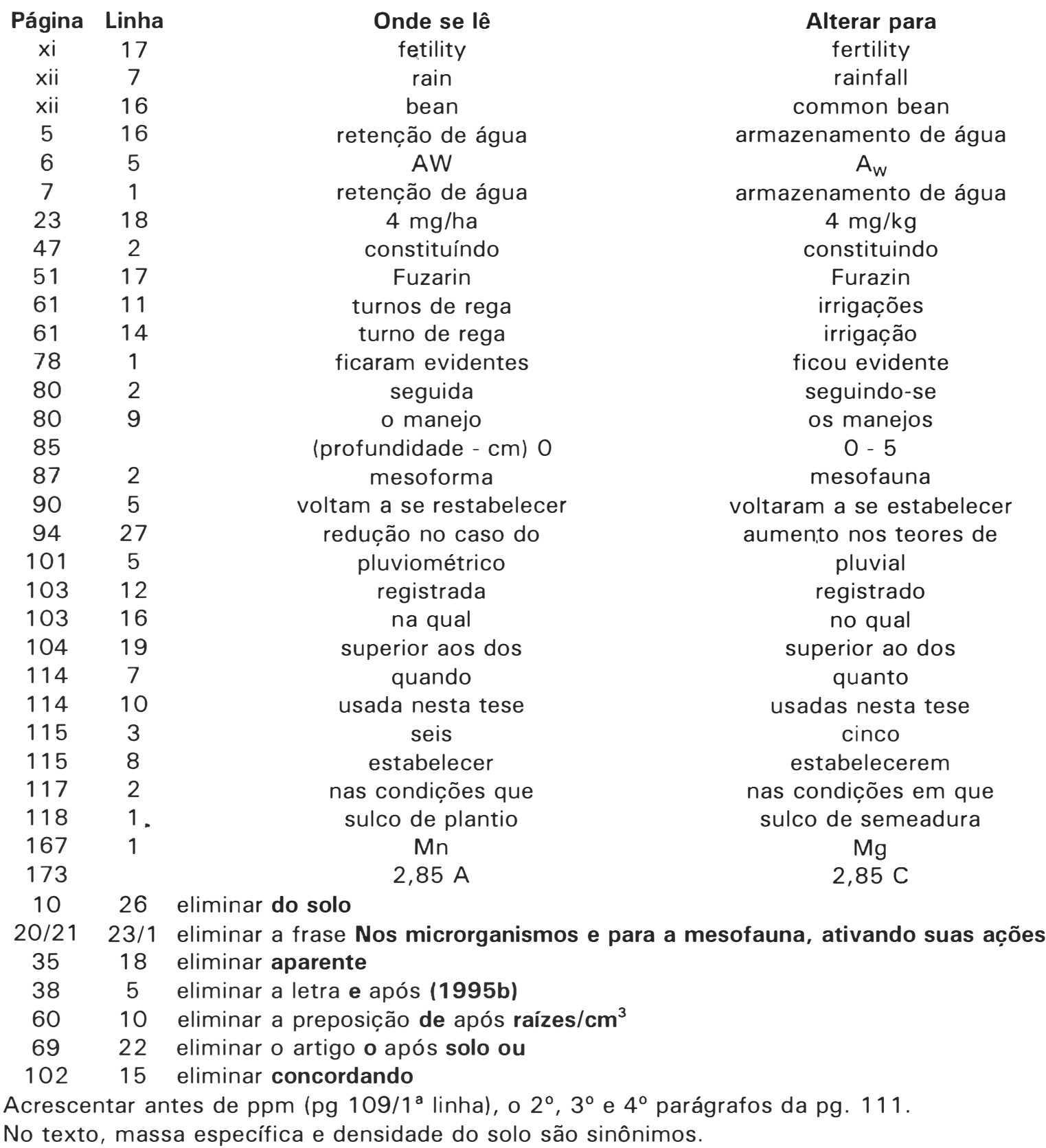




\section{Pontuação}

Acrescentar virgula após (pg/linha): foram (x/9); favoráveis (1/3); principalmente (3/9 e $3 / 20)$; sobretudo (4/1); muito embora (6/20); verifica-se $(6 / 21)$; podendo $(6 / 25)$; atualmente (9/11); tráz (11/21); consequência (11/22); havendo (13/17); solo (14/7); normalmente (17/4); simultâneamente (21/25); pelo menos (23/25); podendo (25/20); no máximo (27/5 e 6); observaram (33/17); subsuperficial (34/27); (1983) (37/8); decréscimo (38/25); feijão (47/6); normalmente (53/2); arroz (60/18); por conseguinte (64/10); consequência (68/13); em média (69/4); área (69/3); escarificação (71/6); Cu (73/22); ocorrido (73/23); provavelmente (73/24); perfil (78/2); 0,5 mm (84/21); (1997b) (87/9); R. solani (87/15); suficiência (94/2); escarificação (94/16); lógica (94/20); g/cm $\mathrm{cm}^{3}$ e (103/19); o que (104/3); verificaram que (106/18); e fértilizantes (116/2).

Acrescentar vírgula antes de (pg/linha): principalmente (3/9 e 3/20); sobretudo (4/1); atualmente (9/11); pelo menos (23/25); normalmente (53/2); por conseguinte (64/10); em média (64/4); R. solani (87/15); e principalmente (90/2).

Eliminar virgula após (pg/linha): grãos (x/11); (1983) (14/24); inicial (16/4); 1984 (18/1); 1991 (18/10); baixa (24/1); (1988) (27/15); (1988) (39/15); duplo (49/16); milho (56/3); (DMP) (58/8); impurezas (60/5); vazias (63/3); mês (69/22); $M n$ (73/18); homogênea (73/23); amostral (73/24); (1995) (84/17); aradora (94/14); et al. (99/24); g/cm $\mathrm{cm}^{3}(103 / 19)$; grãos (106/2); observou-se (106/3); 1997 (106/8); (1981) (106/13); (1989) (106/18); 1997 (106/22); (1997) (107/1); 1998 (107/5); (1997) (111/20); e 1998 (112/23). 
Dados Internacionais de Catalogação na Publicação (CIP) DIVISÃO DE BIBLIOTECA E DOCUMENTAÇÃO - Campus "Luiz de Queiroz"/USP

\section{Kluthcouski, Joว̄o}

Efeito de manejo em alguns atributos de um latossolo roxo sob cerrado e nas características produtivas de milho, soja, arroz e feijāo, após oito anos de plantio direto / Joāo Kluthcouski. - - Piracicaba, 1998.

179 p. : il.

Tese (doutorado) - Escola Superior de Agricultura Luiz de Queiroz, 1998 Bibliografia.

1. Adubaçāo 2. Arroz 3. Compactaçāo do solo 4. Enraizamento 5. Feiiāo 6. Manejo do solo 7. Milho 8. Nutriente 9. Plantio direto 10. Soja I. Titulo 
Aos meus pais

Romão (in memorian) e Anna (in memorian), porque para mim vocês foram simbolos do trabalho, da dignidade e da honestidade e também porque muito amaram esta pátria sem nunca ferir a ética de cidadãos brasileiros.

Ao José, Pedro, Lídia, Paulo e Júlio, pelo orgulho de tê-los como irmãos.

Aos meus filhos,

João Marcelo, pela dedicação aos estudos e porque a vida lhe será repleta de ensinamentos sobre a real grandeza da compreensão, participação, solidariedade e felicidade.

Carlos Michel, pela grata companhia durante os tempos infantes e porque, com a benção de Deus, você sempre saberá decidir pela harmonia.

Sérgio Murilo, pela dedicação a tudo que faz, por compreender que as maiores dificuldades são os melhores ensinamentos e ainda por saber que você não só alcançará todos os seus objetivos, como, tenho certeza, superará seus próprios limites.

João Matheus, porque você não veio ao mundo como convencional, mas como um exemplo irradiante de amor e solidariedade. Veio como um mago cativante e como um exemplo de que nós, ditos inteligentes, temos muito a aprender sobre a paz e a harmonia entre os seres. Obrigado por ter me educado sobre o simples e por ter me mostrado o lado bom da nossa existência - Paiá ama muito Gugú eu.

Eu os amo e 


\section{AGRADECIMENTOS}

Ao Prof. Dr. Antônio Luiz Fancelli, pela orientação, apoio, tempo e esforço dispensados para a realização desta tese e, principalmente pelo conhecimento e qualidade com os quais transmitiu os fundamentos da agricultura sustentável, e também pelo gesto de orientador amigo.

Ao Prof. Dr. Durval Dourado Neto, por ser um exemplo de profissional capaz, dedicado e amigo em todos os momentos.

À Embrapa, através do Centro Nacional de Pesquisa do Arroz e FeijãoCNPAF, pela oportunidade de realização deste curso e pelo suporte financeiro.

Aos Doutores Homero Aidar, Luis Fernando Stone, José Geraldo da Silva, Pedro Antonio Arraes Pereira, Orlando Peixoto de Morais e Joaquim de Carvalho Gomide, dirigentes do CNPAF, pelo apoio integral durante o período de realização deste curso.

Aos Professores Doutores Gil Miguel de Sousa Câmara, Geraldo José Aparecido Dário, Ricardo Victória Filho, Pedro Cristofoletti, Godofredo César Vitti, Decio Barbin, Silvio de Moura Cícero e Marcos Silveira Bernardes pelos ensinamentos, apoio e atenção.

Ao Dr. Ricardo de Castro Merola, proprietário da fazenda Três Irmãos pelo precioso apoio e acompanhamento na realização deste estudo e pelo exemplo que tem sido na adoc̣ão e divulgação de novas tecnologias.

À equipe de apoio do CNPAF, Floriano Rezende da Silva, José Augusto de Souza, João Ananias Miranda, Sebastião Ferreira da Silva, João Batista Monteiro e Antônio da Conceição Teixeira, por serem um exemplo de dedicação e amizade.

Aos Doutores Luis Fernando Stone, Beatriz da Silveira Pinheiro, Orlando Peixoto de Morais, Itamar Pereira de Oliveira, Ana Lucia Delalibera 
de Faria e Nand Kumar Fageria pela análise criteriosa e sugestões para esta tese.

Aos laboratoristas Vandélio Afonso de Oliveira, Adilson Francisco da Costa Vilela, Heloisa da Silva Coelho, Silvio Domingos de Rezende e Maria Divina e Silva Souza pelo relevante apoio laboratorial.

Aos digitadores Celina Alves Avelino de Moura, Daniel de Oliveira, Fabiano Severino, Ana Silvia de Oliveira e Sebastião José de Araújo pela presteza e carinho com que contribuíram para este trabalho.

Ao Dr. Francisco José Zimmermann pelo valioso apoio estatístico.

Ao Dr. Jefferson Luiz da Silva Costa pela análise crítica e apoio no tema microbiologia do solo.

Ao Prof. Dr. Tomás de Aquino Portes e Castro, da Universidade Federal de Goiás, pelas sugestões, análise crítica e amizade sincera.

À Sra. Layne Tomé pela apreciação da ortografia.

Aos bibliotecários Jeová José Brandão e Elise Schlag pelo profissionalismo e auxílio amigo.

A todos os pesquisadores e funcionários do CNPAF, em especial aos Doutores Pedro Marques da Silveira, Carlos Rava Agustin Seijas, Luiz Carlos Balbino, Michael D.T. Thung, Claudio U. Mangabosco, Paulo H.N. Rangel, Josias C. de Faria, Maria José Del Peloso, Massaru Yokoyama, Lidia P. Yokoyama, Evane Ferreira, Tarcisio Cobucci, José Geraldo Di Stefano, Leo Darck da Costa, Carlos Magri Ferreira, Corival Cândido da Silva e Dino Magalhães Soares, pelos constantes estímulos.

Aos técnicos e servidores da fazenda Três irmãos, Eliseu Marson Filho, Antônio Aparecido Portella, Egno Teobaldo, Joana Dália de Lima e Eliandra C.B. Oliveira pelas valorosas contribuições nos experimentos.

À estagiária Andréa Alves de Siqueira pela conferência das tabelas. 
Ao Sr. Edson Cardoso, técnico da empresa Ikeda e Filhos, pela preciosa cooperação no manejo do solo para os experimentos.

Aos servidores da ESALQ/USP, Margarida F. Freitas, Edson Moraes, Ilze H.C.G. Neves, Osmair Neves, Antônio Arruda, Adriana A.T.Gimenes, Celestino Alves Ferreira, Jair Vitório Arthur e Maria Aparecida Teixeira Soledade pelo apoio e colaboração.

Aos companheiros de curso, em nome de Clovis P. Peixoto, Edson Teramoto, Dioger Teruel, Cristina Maria Ribeiro, Luiz Antônio Ferraro, Oscar José Smiderle, Vicente de Paula Martello, Carlos Moura Cícero, Omar Vieira Vilella e João Luiz Gadioli, pela amizade e constante permuta de valiosas idéias.

Aos doutores Almiro Blumenschein e Lyle E. Nelson por terem sido preciosas fontes de experiência, nas quais muito me inspiro.

Às empresas Monsanto do Brasil, Iharabras S.A. e Ikeda e Filhos, respectivamente nas pessoas dos doutores Márcio Scaléa, Sergio Yoshiaki Maruiti e José Takahashi, pelo precioso apoio financeiro ou logístico.

A todos que, direta ou indiretamente, colaboraram para a realização do curso. 


\section{SUMÁRIO}

Página

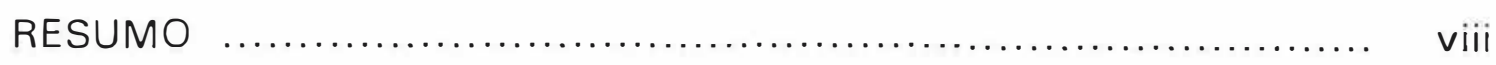

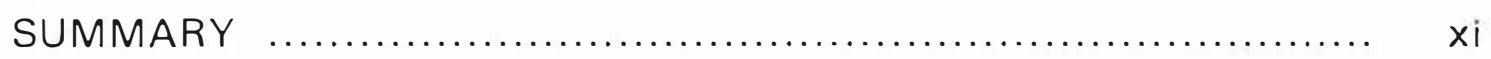

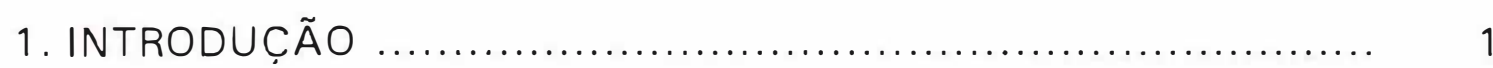

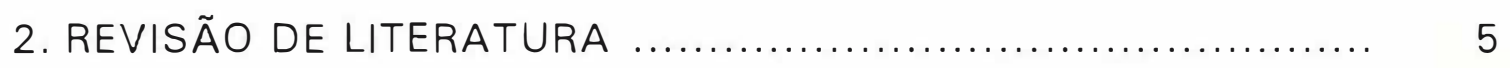

2.1. O cerrado: solo, clima e exploração agropecuária .......... 5

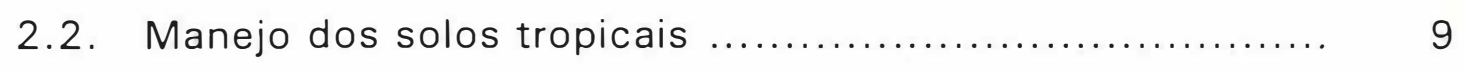

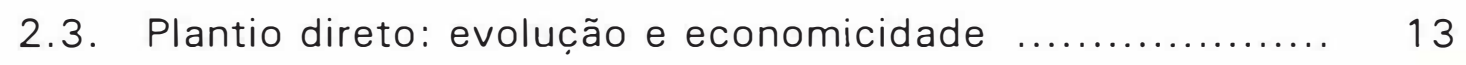

2.4. Cobertura morta e cobertura do solo no plantio direto .... 15

2.5. Manejo do solo e algumas características físicas ......... 16

2.6. Alguns aspectos biológicos do solo $\ldots \ldots \ldots \ldots \ldots \ldots \ldots \ldots \ldots . . \ldots$

2.7. Comportamento dos nutrientes no solo em função do manejo e resposta das culturas à adubação $\ldots . . . \ldots \ldots \ldots . . . . .23$

2.8. Suficiência de nutrientes nas plantas e exportação pelas

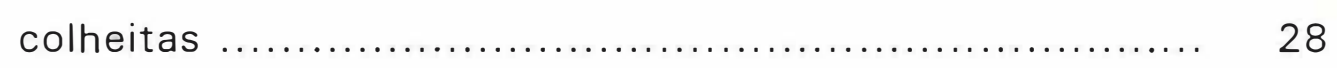

2.9. Manejo do solo e desenvolvimento radicular das plantas.. 29

2.10. Manejo do solo e rendimento das culturas ................ 36

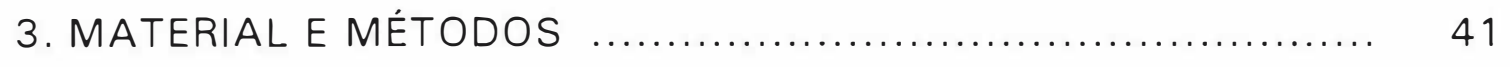

3.1. Caracterização da região e da área experimental ........... 41

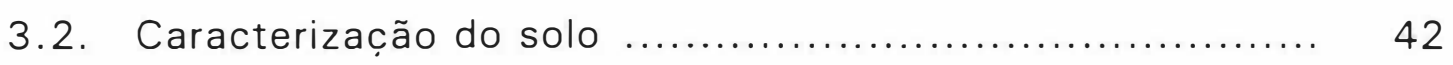

3.3. Tratamentos experimentais .......................... 46

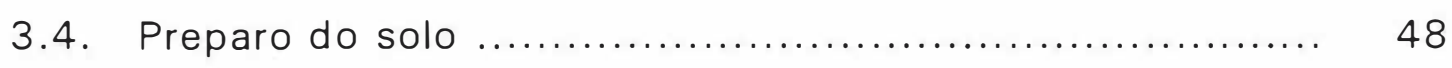

3.4.1. Aração profunda com arado de aivecas (AP) ..... 48

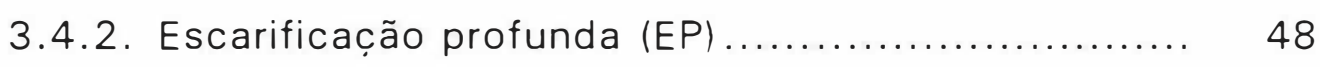

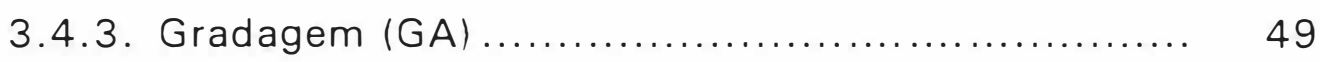


Página

3.5. Adubação e semeadura $\ldots \ldots \ldots \ldots \ldots \ldots \ldots \ldots \ldots \ldots \ldots \ldots \ldots \ldots \ldots \ldots \ldots . \ldots \ldots$

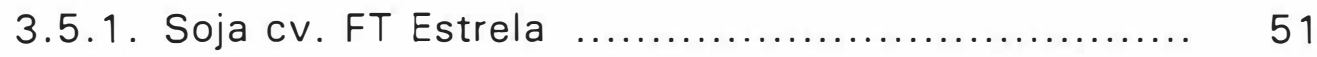

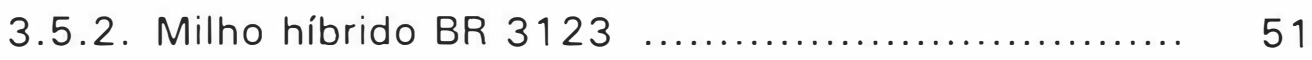

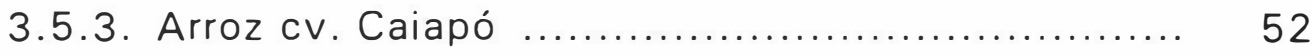

3.5.4. Feijão cv. Jalo Precoce ......................... 52

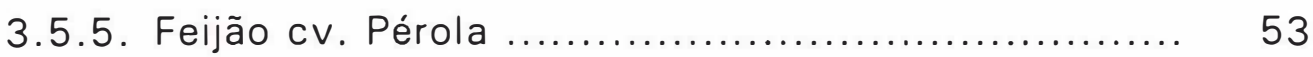

3.6. Avaliação da população inicial de plantas .................. 53

3.7. Amostragens ....................................... 54

3.7.1. Análise química do solo ....................... 54

3.7.2. Análise física do solo .......................... 54

3.7.3. Análise microbiológica do solo ................... 55

3.7.4. Densidade radicular ........................... 55

3.7.5. Análise foliar ................................. 55

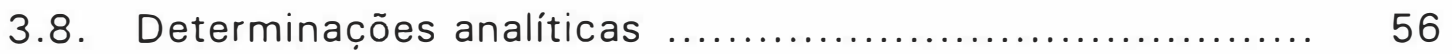

3.8.1. Análise química do solo ....................... 56

3.8.2. Análise física do solo ........................... 57

3.8.3. Análise microbiológica do solo ................... 58

3.8.4. Análise foliar ................................. 59

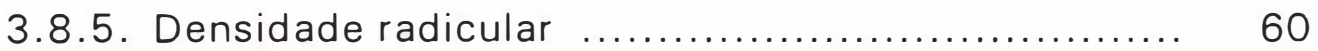

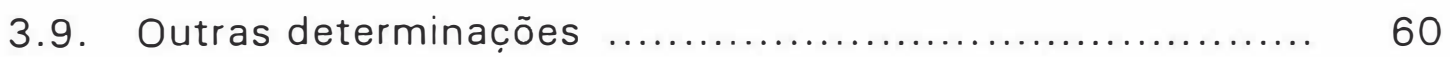

3.10. Manejo da irrigação na cultura do feijão .................. 61

3.11. Colheita e avaliação dos componentes do rendimento ... 61

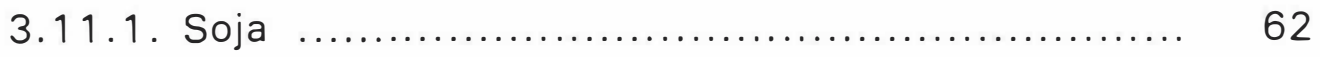

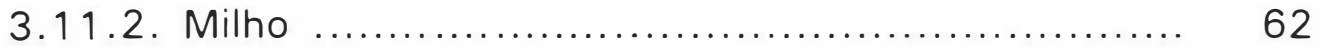

3.11.3. Arroz de terras altas ........................ 62

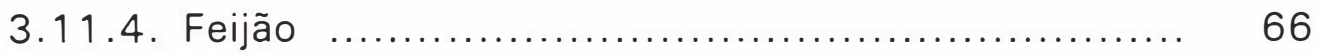

3.12. Procedimentos estatísticos ............................ 63 


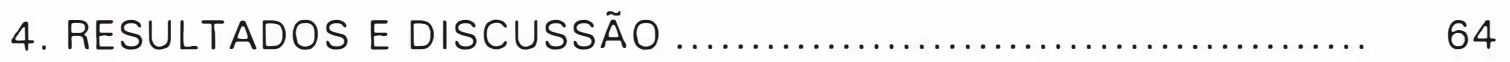

4.1. Condições climáticas durante o período de condução dos experimentos

4.2. Propriedades químicas e físicas do solo, após oito anos sob plantio direto

4.3. Cobertura do solo com resíduos vegetais

4.4. Comportamento da fertilidade do solo nos diferentes manejos após a colheita das culturas

4.5. Comportamento de algumas propriedades físicas do solo sob os diferentes manejos

4.6. Manejo do solo e alguns aspectos microbiológicos

4.7. Concentração de nutrientes nas folhas das culturas em função do manejo do solo

4.8. Manejo do solo e enraizamento das culturas

4.9. Manejo do solo e rendimento das culturas

4.10. Conversão de unidades

4.11. Considerações finais

5. CONCLUSÕES

6. REFERÊNCIAS BIBLIOGRÁFICAS

8. Fotos: Vista parcial dos experimentos. 


\title{
EFEITO DE MANEJO EM ALGUNS ATRIBUTOS DE UM LATOSSOLO ROXO SOB CERRADO E NAS CARACTERÍSTICAS PRODUTIVAS DE MILHO, SOJA, ARROZ E FEIJÃO, APÓS OITO ANOS DE PLANTIO DIRETO
}

\author{
Autor: João Kluthcouski \\ Orientador: Prof. Dr. Antônio Luiz Fancelli
}

\section{RESUMO}

O sistema de plantio direto tem obtido expressiva adoção por agricultores do cerrado brasileiro e vem sendo uma das melhores opções de sistema conservacionista. No entanto, seu uso continuado em regiões tropicais com freqüente insuficiência de cobertura do solo, aliado às sucessivas adubações superficiais, pode resultar em alterações nos parâmetros físicos e químicos do solo, tais como compactação e acúmulo excessivo de nutrientes na superfície, com conseqüente inibição no desenvolvimento radicular das plantas e na expressão do potencial produtivo das culturas.

Este estudo teve como principal objetivo avaliar a necessidade de descompactação do solo e/ou homogeneização da fertilidade no perfil mais explorado pelas raizes. Utilizou-se uma área cultivada por oito anos no sistema de plantio direto e com cerca de três cultivos por ano agrícola, sendo com irrigação por aspersão no período de inverno. Avaliou-se o efeito de quatro manejos do solo: plantio direto; grade aradora; escarificação 
profunda e aração profunda com arado de aivecas, com três níveis de adubação $P$ e K: testemunha; recomendação oficial para a região e equivalente às quantidades exportadas pelas colheitas. Os experimentos com as culturas do milho, soja, feijão e arroz de terras altas foram conduzidos em um Latossolo Roxo eutrófico, de alta fertilidade, no município de Santa Helena-GO, e implantados no esquema de faixas e delineamento de blocos completos casualizados, com quatro repetições. As variáveis avaliadas foram a porosidade, a densidade e os agregados do solo, a distribuição dos nutrientes no perfil, o enraizamento das culturas, o acúmulo foliar de nutrientes, o comportamento de alguns fungos patogênicos do solo, a produtividade e seus componentes e alguns aspectos fisiológicos das culturas. O ano agrícola apresentou duas variações climáticas: excesso de chuvas nos estádios iniciais de desenvolvimento das culturas e escassez nos estádios finais.

A análise dos principais resultados mostrou que, após oito anos sob plantio direto, houve elevação na massa específica do solo no perfil 5-20 cm, com conseqüente redução na macroporosidade, bem como o acúmulo superficial de alguns nutrientes, principalmente o Mg, P, K, Zn e Mn.

Tanto a aração como a escarificação elevaram o percentual de macroporos no perfil, reduzindo a massa específica do solo temporariamente. No caso da aração, ocorreu a homogeneização de alguns nutrientes no perfil trabalhado, resultando em alterações significativas na distribuição de raízes das plantas de milho e feijão e não significativas para o arroz e soja, cuja maior concentração, independente do manejo do solo e da cultura, situou-se nos $20 \mathrm{~cm}$ superficiais do perfil do solo.

A alta variabilidade observada na concentração e distribuição dos nutrientes no perfil do solo sugere necessidade de alterações nos métodos de amostragem para o sistema de plantio direto. Também, independente do 
manejo do solo e da adubação, a concentração foliar de nutrientes, de modo geral, não variou, permanecendo, exceto para o arroz, na faixa adequada para as culturas. Esta observação sugere a necessidade de reestudo dos niveis de adubação em áreas sob plantio direto e com alta fertilidade do solo.

As populações de Rhizoctonia solani e Fusarium solani foram relativamente altas no plantio direto, podendo ter contribuído para a redução na população final de plantas das leguminosas. Na aração, estas populações foram temporariamente, significativamente menores, registrando-se também redução na atividade microbiológica do solo e na população bacteriana total. O rendimento de grãos, variou conforme a espécie cultivada. Não houve resposta da soja aos diferentes manejos do solo nem aos níveis de adubação. A aração com aivecas, por sua vez, resultou nos maiores rendimentos de milho, arroz e feijão, sendo intermediários os efeitos provocados pela escarificação.

Exceto para o feijão, nestas culturas também não se verificou efeito significativo da adubação. As leguminosas apresentaram maior adaptabilidade às modificações do solo, impostas pelo uso continuado do plantio direto, enquanto o arroz mostrou-se o mais sensível. Ainda assim e, exceto para o arroz, o sistema de plantio direto mostrou-se altamente vantajoso. Não foi possível, no entanto, para as culturas tradicionais e nas condições em que os experimentos foram conduzidos, decidir sobre a necessidade de descompactação cíclica do solo através da mobilização por aração ou escarificação. 


\section{EFFECT OF MANAGEMENT ON SOME PROPERTIES OF A SAVANNAH OXISOL AND ON THE PRODUCTIVE CHARACTERISTICS OF CORN, SOYBEAN, UPLAND RICE AND COMMON BEAN, AFTER EIGHT YEARS OF CONTINUOUS NO-TILLAGE}

Author: João Kluthcouski

Adviser: Prof. Dr. Antônio Luiz Fancelli

\section{SUMMARY}

In the Brazilian savannah region, no-tillage cropping system has been widely adopted by farmers and represents one of the best environment conservacionist practices. Continuous utilization of this system under tropical conditions, however, with insufficient mulching and successive superficial fertilization, alters soil chemical and physical properties, resulting in compaction and excessive accumulation of nutrients on the surface layer which may impose problems to root growth and crop yield. The main objective of this study was to evaluate the need for soil subsurface decompaction and/or to homogenize fetility on soil profile most explored by plant root system. The area utilized in the experiments was maintained under no-tillage for eight consecutive years and it was cropped near three times each year, using sprinkler irrigation during the winter season. The treatments comprised four soil management methods (no-tillage; heavy harrowing; deep chiseling; and deep moldboard plowing) combined to three levels of $P$ and $K$ fertilization (no fertilizer application; recommended fertilization; reposition of nutrients removed by grains). The trials, using corn, soybean, upland rice and common bean, were carried out in an Oxisol 
with high fertility in Santa Helena, southwest region of Goiás State. The experiments were conducted on a complete block design, using strip plots and four replications. Variables evaluated were: porosity; bulk density and aggregates; nutrient distribution and root development in the soil profile; nutrient accumulation in the leaves; behavior of some pathogenic fungi in the soil; yield and yield components; and some plant physiological aspects. During the cropping season two variations on rain distribuition were observed: excess water at plant early growth stages and water deficiency at grain filling.

After the eight year period, it was observed an increase in bulk density at $5-20 \mathrm{~cm}$ soil depth with consequent reduction in macroporosity as well as on superficial nutrient accumulation, especially $P, K, Z n$, and $\mathrm{Mn}$ at $0-10 \mathrm{~cm}$ layer. Plowing, as well as chiseling, temporarily raised soil macropore percentage and decreased bulk density. For moldboard plowing it was observed nutrient homogenization in the turned over profile. These changes resulted in significant modifications on bean and corn root distribution, which concentrated at $20 \mathrm{~cm}$ soil depth, despite the management method utilized. The high level of variability observed on nutrient concentration and distribution indicates the need to modify the soil sampling method when no-tillage system is utilized. In general, leaf nutrient concentration did not vary with soil management or fertilization practices and remained in adequate levels for all crops studied with the exception of rice. This fact suggests that fertilizer recommendations for no-tillage cropping systems associated to high fertility soils should be reviewed. Populations of Rhizoctonia solani and Fusarium solani were relatively high under no-tillage and may have affected final plant stand, mainly in the legume species. Moldboard plowing temporarily reduced these populations but also reduced soil biological activity and total bacteria population. Grain 
yield, on the other hand, varied according to the crop. Soil management or fertility did not affect soybean yield while moldboard plowing significantly increased corn, rice and common bean yields. The bean crop also showed positive effects of $P$ and $K$ applications. Legume crops appeared to be more adapted to soil changes caused by continuous no-tillage while rice was more sensitive. Even thought no-tillage appears to be very advantageous, except for upland rice, it was not possible to take a decision whether decompaction, by plowing or chiseling, is necessary. 


\section{INTRODUC̣ÃO}

O cerrado brasileiro ocupa uma área superior a 200 milhões de hectares e apresenta alto potencial para a produção agropecuária. Graças a alguns atributos climáticos favoráveis é possível o uso intensivo do solo durante todo o ano, na maioria das sub-regiões, desde que se proceda a irrigação durante o período de inverno. Os solos desta região, no entanto, apresentam limitações naturais, de ordem química e, dependendo do manejo, também de natureza física e biológica.

A dominância de sistemas convencionais de manejo nestes solos, baseados no intensivo revolvimento, modifica a sua estrutura, alterando seus parâmetros físicos. O uso intensivo dos arados e grades de disco fraciona os agregados do solo. Por sua vez, a ação do clima quente e úmido, durante a maior parte do ano, acelera a decomposição da matéria orgânica. Estes fatores, aliados à inadequação da seqüência de culturas, têm resultado na redução da capacidade produtiva de grande parte dos solos tropicais ao longo do tempo. Os principais indicadores desta falta de sustentabilidade são a compactação, a erosão hídrica e eólica, a redução na atividade biológica do solo e o aumento dos fatores bióticos nocivos às culturas.

Estas distorções tornam obrigatório o uso cada vez mais freqüente e crescente de fertilizantes minerais e defensivos, aumentando sobremaneira 
os gastos energéticos. Devido a algumas características mineralógicas indesejáveis, os solos dominantes no cerrado, Latossolos e Areia Quartzozas, são altamente dependentes da matéria orgânica para a manutenção e/ou ampliação de sua capacidade produtiva. Deste processo, destacam-se a elevação da capacidade de troca de cátions (CTC), agregação das partículas, infiltração e armazenamento de água, manutenção da densidade e porosidade em níveis adequados, dentre outros.

Neste contexto, tanto no cerrado, como também em níveis mundiais, a atividade agrícola vem sofrendo profundas alterações nas práticas que envolvem os sistemas de produção. Tais alterações não são meramente decorrentes da evolução tecnológica, mas também de pressões ambientalistas, concorrência de mercado resultante da globalização da economia, redução na relação benefício/custo, necessidade da redução dos gastos energéticos, manutenção da capacidade produtiva do meio e extinção de fontes de recursos fáceis e baratos.

Nas regiões tropicais, devido às adversidades climáticas, as maneiras viáveis de se elevar a capacidade produtiva dos solos, além do seu manejo correto, da fertilização adequada e balanceada e da apropriação nas sucessões ou rotações de culturas, parecem ser a utilização de sistemas agropastoris e a semeadura direta, mantendo-se os resíduos vegetais na superfície do solo. Neste contexto, houve uma rápida evolução tecnológica no cerrado que permitiu a solução parcial ou total dos problemas relacionados à implantação do sistema de plantio direto. Destacam-se a formação de cobertura morta, correção das propriedades químicas e físicas do perfil do solo, controle de plantas daninhas, rotação/sucessão de culturas e a mecanização do plantio. 
Apesar de ainda existirem algumas dúvidas sobre estes temas, a adoção deste sistema pelos agricultores no cerrado tem sido substancial, principalmente nos últimos quatro anos. Os principais propulsores desta adoção são a redução na erosão, manutenção e aumento da fertilidade química e biológica do solo, facilidade e oportunidade de plantio, economia de combustível e maquinário agrícola e a redução na necessidade de mãode-obra.

Entretanto, sob as condições climáticas reinantes no cerrado, tem sido difícil a formação e principalmente a manutenção de volume de palhada em quantidade suficiente para proteger plenamente a superfície do solo. Isto, aliado à intensa movimentação de máquinas e implementos, pode favorecer o surgimento de problemas de segunda geração, ou aqueles decorrentes do uso continuado do sistema de plantio direto. Os principais são a intensificação de problemas relacionados a fungos do solo; salinização devido à constante deposição dos fertilizantes minerais na superfície; efeito depressivo da fertilidade superficial sobre o desenvolvimento radicular das plantas; efeitos nocivos de defensivos utilizados indiscriminadamente; seletividade e resistência de espécies de plantas daninhas aos principais herbicidas; necessidade de rearranjo espacial das plantas para as novas condições físicas, químicas e biológicas do solo e principalmente o readensamento/compactação da superfície e subsuperfície do solo.

A concentração superficial dos nutrientes, bem como a redução na macroporosidade, podem interferir no desenvolvimento radicular das plantas cultivadas, principalmente em profundidade e assim, comprometer a produtividade das culturas, sobretudo nos sistemas de exploração que dependem exclusivamente de chuvas. Por estas razões, é possível que a perenização do sistema de plantio direto dependa da interação cíclica de 
sistemas convencionais apropriados de manejo do solo, visando sobretudo a uniformização das propriedades físicas e químicas do perfil do solo.

O presente estudo teve como objetivo principal verificar se o uso continuado do sistema de plantio direto, nas condições de cerrado, altera algumas propriedades físicas, químicas e biológicas do solo, tornandoas limitantes ao bom desenvolvimento e reprodução das culturas do milho, soja, arroz de terras altas e feijão.

“Em ciência, explicações são sempre provisórias, mesmo que muito eficientes por algum tempo". 


\section{REVISÃO DE LITERATURA}

\subsection{O cerrado: solo, clima e exploração agropecuária}

O cerrado brasileiro, estendendo-se principalmente pela região Centro-Oeste e atingindo ainda parte das regiões Norte, Nordeste e Sudeste, ocupa uma área superior a 200 milhões de hectares, sendo dois terços aptos para a exploração agropecuária, com possibilidade de irrigação para cerca de 10 milhões de hectares (Goedert et al., 1980). Os solos dominantes são os Latossolos (56\%), Areias Quartzosas (20\%) e Laterita Hidromórfica (10\%) (Sanchez et al., 1974 citado por Goedert, 1980). Como conseqüência da alta intemperização, tais solos perderam por lixiviação, grande parte dos seus cátions. Os solos são geralmente ácidos, deficientes em $\mathrm{Ca}, \mathrm{Mg}, \mathrm{P}, \mathrm{Zn}$, com alta saturação de alumínio e baixa CTC, e ainda moderadamente deficientes em K e alguns micronutrientes (Lopes, 1983). A argila predominante é a caulinita, $1: 1$, não expansiva e de baixa atividade. Outras peculiaridades destes solos são alta taxa de infiltração, baixa capacidade de retenção de água e relevo suave ondulado, com pendentes, em geral, inferiores a $4 \%$, favorecendo a agricultura mecanizada (Carmo, 1997).

Existem diferenças consideráveis de clima na região do cerrado brasileiro, principalmente com relação à temperatura, devidas à grande 
extensão territorial e variação de altitude. Existem explorações agrícolas em todas as sub-regiões, pois a temperatura e a radiação solar, durante praticamente o ano inteiro, são favoráveis a esta atividade.

O clima predominante, pela classificação de Köppen, é do tipo AW, tropical e chuvoso (EMBRAPA, 1993). A temperatura média anual é de cerca de $22^{\circ} \mathrm{C}$, com média das mínimas em torno de $16^{\circ} \mathrm{C}$ e das máximas de $27^{\circ} \mathrm{C}$, dificilmente ocorrendo geadas na parte sul da região (Goedert, 1980). Ainda, segundo este autor, a radiação solar varia em torno de $450 \mathrm{cal} / \mathrm{cm}^{2} / \mathrm{dia}$, sendo suficiente para a maioria dos cultivos. O regime de chuvas é constituido por duas estações bem distintas e características. 0 período chuvoso vai de setembro/outubro até abril/maio, com precipitação total variando entre 1000 e 1700 mm/ano. Há, porém, regiões sob influência amazônica com mais de 2500 mm/ano (Seguy et al., 1989), onde, durante o período chuvoso de quase todos os anos, ocorre pelo menos uma chuva com mais de 100 mm/dia (Sandanielo et al., 1992; Silva et al., 1994). De um modo geral, no cerrado, as chuvas são de curta duração e grande intensidade. São chuvas de grande energia e com intensidade acima da capacidade de infiltração de água no solo, potencializando os efeitos da erosão hídrica (Goedert, 1980).

Muito embora durante o período chuvoso, a média das precipitações seja considerada boa, verifica-se sistematicamente, a ocorrência de freqüentes períodos secos ou "veranicos", que variam, em média, de sete até mais de vinte dias. Estes veranicos, que geralmente ocorrem nos meses de janeiro e fevereiro, com muita freqüência têm ocasionado significativa diminuição de produtividade das culturas, podendo em alguns casos, ser superior a 70\% (Carmo, 1997). O efeito dos veranicos é agravado pela elevada aemanda evaporativa da atmosfera, baixa 
capacidade de retenção de água da maioria dos solos e limitado desenvolvimento radicular das culturas (Azevedo et al., 1983).

A dimensão das propriedades rurais no cerrado difere da encontrada em outras regiões brasileiras, já que, a exemplo do Brasil Central, mais de $62 \%$ da área são representados por propriedades com área superior a 1000 ha, enquanto menos de 0,5\% é ocupado por propriedade entre 0,1 e 100 hectares (Teixeira et al., 1986 citado por Seguy et al., 1989).

Em consequência dos aspectos favoráveis à prática da agricultura e pecuária, o cerrado tem apresentado um desenvolvimento agrícola acelerado nos últimos anos, aumentando significativamente sua participação na produção nacional de alimentos e matérias primas, respondendo atualmente por cerca de $27 \%$ da produção de grãos e $42 \%$ do rebanho bovino brasileiro (Ker et al., 1992). A ocupação da região-iniciouse na década de 60 e em 1991 culminou com mais de 42 milhões 'de hectares com pastagem cultivada e 75 milhões de hectares de pastagem nativa. A área cultivada com lavouras temporárias é de 13,5 milhões de hectares, ou $6,7 \%$ da área do bioma (EMBRAPA, 1995). As culturas do arroz, milho, feijão e soja, em 1993, eram cultivadas em cerca de 9,5 milhões de hectares, representando, exceto para o feijão, cerca de $30 \%$ da produção nacional. Os rendimentos médios obtidos, entretanto, são bastante baixos e não diferem da média brasileira, se comparados com os rendimentos obtidos por bons produtores na região (Tabela 1).

Apesar da região dos cerrados reunir um conjunto de fatores que favorecem as atividades de produção de alimentos, fibras e energia, os sistemas agrícolas praticados são ainda de baixa eficiência, devido, principalmente, ao inadequado manejo do solo e da água, além do insuficiente nível de planejamento e gerenciamento do processo produtivo. 


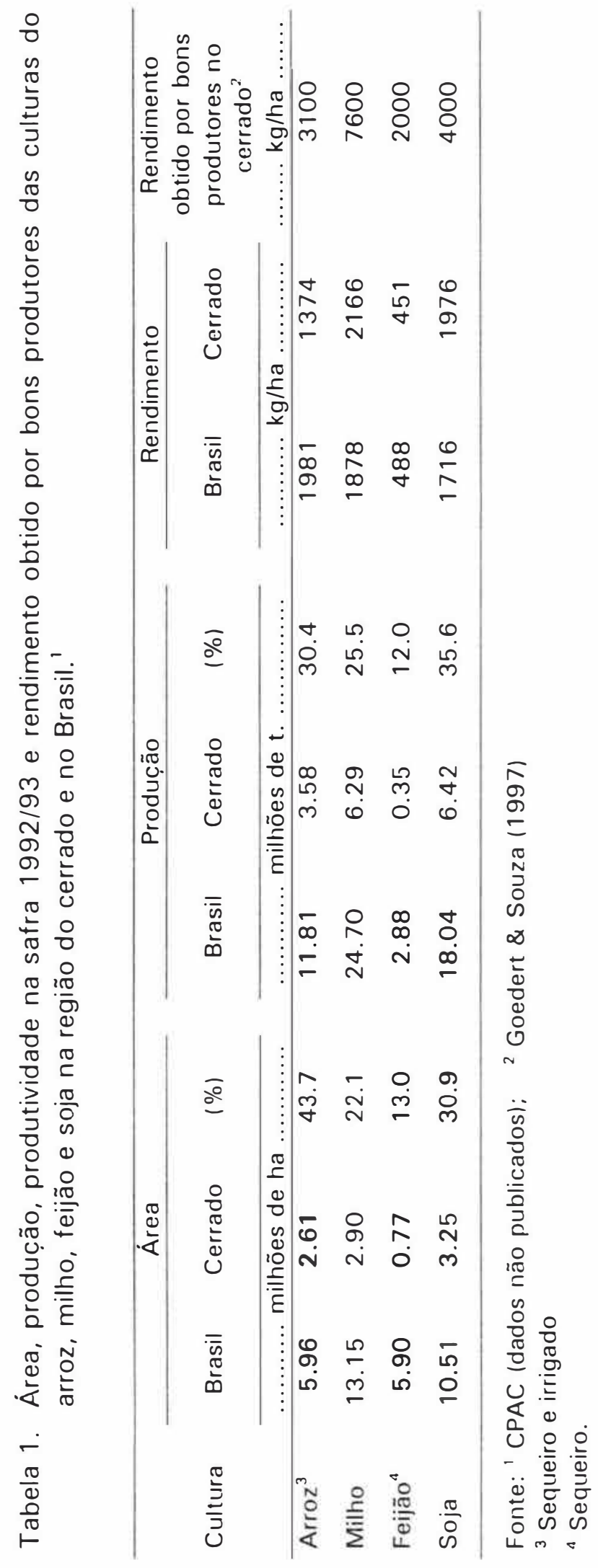


Até bem recentemente, o manejo do solo com grade aradora e niveladora/destorroadora era o principal método utilizado para o preparo do solo, associado à monocultura da soja. Mais recentemente, a partir da década de 80 , parte da área cultivada passou a ser preparada, em rodízio, com escarificadores e arados de disco e aiveca. O plantio direto passou a ser adotado expressivamente a partir do ano agrícola 1993/94, representando hoje cerca de 1,4 milhões de hectares. Também recentemente, iniciou-se o cultivo da "safrinha", preferencialmente com milho e soja, cultivados após a colheita das culturas de verão.

A partir do final da década de 70, iniciaram-se programas de incentivo à irrigação por aspersão. Estima-se que atualmente sejam irrigados cerca de 400 mil hectares no cerrado, três quartos destes com a cultura de feijão, no período de inverno (maio/outubro) ${ }^{1}$. As lavouras sob irrigação são geralmente bem tecnificadas, sendo os rendimentos, principalmente o do feijoeiro, expressivamente superiores, comparados aos das épocas tradicionais de cultivo.

\subsection{Manejo dos solos tropicais}

A prática da agricultura, de um modo geral, tem sido uma atividade predatória em termos de conservação do solo. As terras agrícolas vêm sofrendo um processo acelerado de degradação de sua capacidade produtiva, tanto pelo inadequado e mau uso do solo, devido à mecanização intensa e desordenada, como pelos sistemas agrícolas embasados na monocultura ou sucessões contínuas de culturas (Mondardo, 1984). Nas

\footnotetext{
' Comunicado pessoal. Luis F. Stone. EMBRAPA-CNPAF, 1998.
} 
regiões tropicais e subtropicais, a degradação do solo é ainda mais intensa. Nestas, a mineralização da matéria orgânica chega a ser cerca de 5 vezes mais rápida do que aquela observada em regiões temperadas (Sanchez \& Logan, 1992), o que, via de regra, sobrepõe-se às possibilidades de reposição nos sistemas convencionais de manejo dos solos e das culturas (Derpsch, 1997a).

Os solos do cerrado, notadamente os Latossolos e as Areias Quartzozas, são de modo geral, de textura argilosa, bem estruturados, com alta estabilidade de agregados, principalmente micro agregados, quando não antropizados (Goedert, 1980). Ainda segundo este autor, são solos altamente intemperizados, com CTC altamente dependente da matéria orgânica e composição mineralógica diferente das regiões temperadas. São solos profundos, bem drenados, porém com baixa capacidade de armazenamento de água, comportando-se como solos arenosos (Lopes, 1983). Estas considerações levam a concluir que a água retida no solo é suficiente para manter as culturas em franco desenvolvimento pelo período máximo de 8 dias (Carmo, 1997).

Devido a estas características, sistemas de produção fundamentados no mínimo revolvimento do solo e na manutenção de níveis adequados de matéria orgânica assumem caráter relevante (Fancelli \& Favarin, 1989a). A mobilização da camada arável, proporcionada pelos sucessivos preparos do solo, modifica sua estrutura, alterando a grandeza e a relação de seus parâmetros físicos.

A ação dos implementos agrícolas, principalmente do arado e grades de disco na mobilização do solo, muitas vezes em condições inadequadas de umidade em seu perfil do solo, fraciona e desarranja os agregados do solo e acelera a oxidação da matéria orgânica, tornando os- 
agregados menores e menos estáveis (Denardin \& Kochhann, 1993). Características como muita chuva no verão e período seco no inverno são indesejáveis. O excesso de chuvas provoca erosão e a ausência de palha na superfície facilita a erosão eólica e os efeitos negativos da radiação solar (Gassen \& Gassen, 1996).

A degradação dos solos, com todas as suas implicações e nefastas conseqüências, tem resultado no desafio de viabilizar sistemas de produção que possibilitem maior eficiência energética e conservação ambiental, bem como na criação de novos paradigmas tecnológicos baseados na sustentabilidade. No novo conceito de sistema agrícola produtivo, a fertilidade do solo assume uma abrangência maior do que a habitual, expressada apenas nos parâmetros de acidez, disponibilidade de nutrientes e teor de matéria orgânica. Os parâmetros físicos, armazenamento e conservação de água, armazenamento e difusão do calor e permeabilidade ao ar e à água, e as raízes passam a ter relevância na avaliação da fertilidade do solo (Denardin \& Kochhann, 1993). Neste contexto, o emprego efetivo do sistema de plantio direto, "em função de suas prerrogativas básicas, mostra-se muito mais importante e eficiente para as regiões tropicais e subtropicais exploradas com agricultura" (Fancelli \& Favarin, 1989a).

Em termos gerais, a intensa mobilização dos solos tropicais traz como conseqüência a sua desagregação superficial, sujeita à formação de uma fina crosta, resultante da dispersão das partículas do solo, e outra camada subsuperficial compactada, resultante tanto da pressão exercida pelos implementos agrícolas como dos pneus (Castro et al., 1987). O processo de erosão, resultante destas alterações físicas, representa o fato mais negativo para a sustentabilidade econômica e física da atividade agrícola, e também, o de maior agressividade ao meio ambiente (Figura 1). 


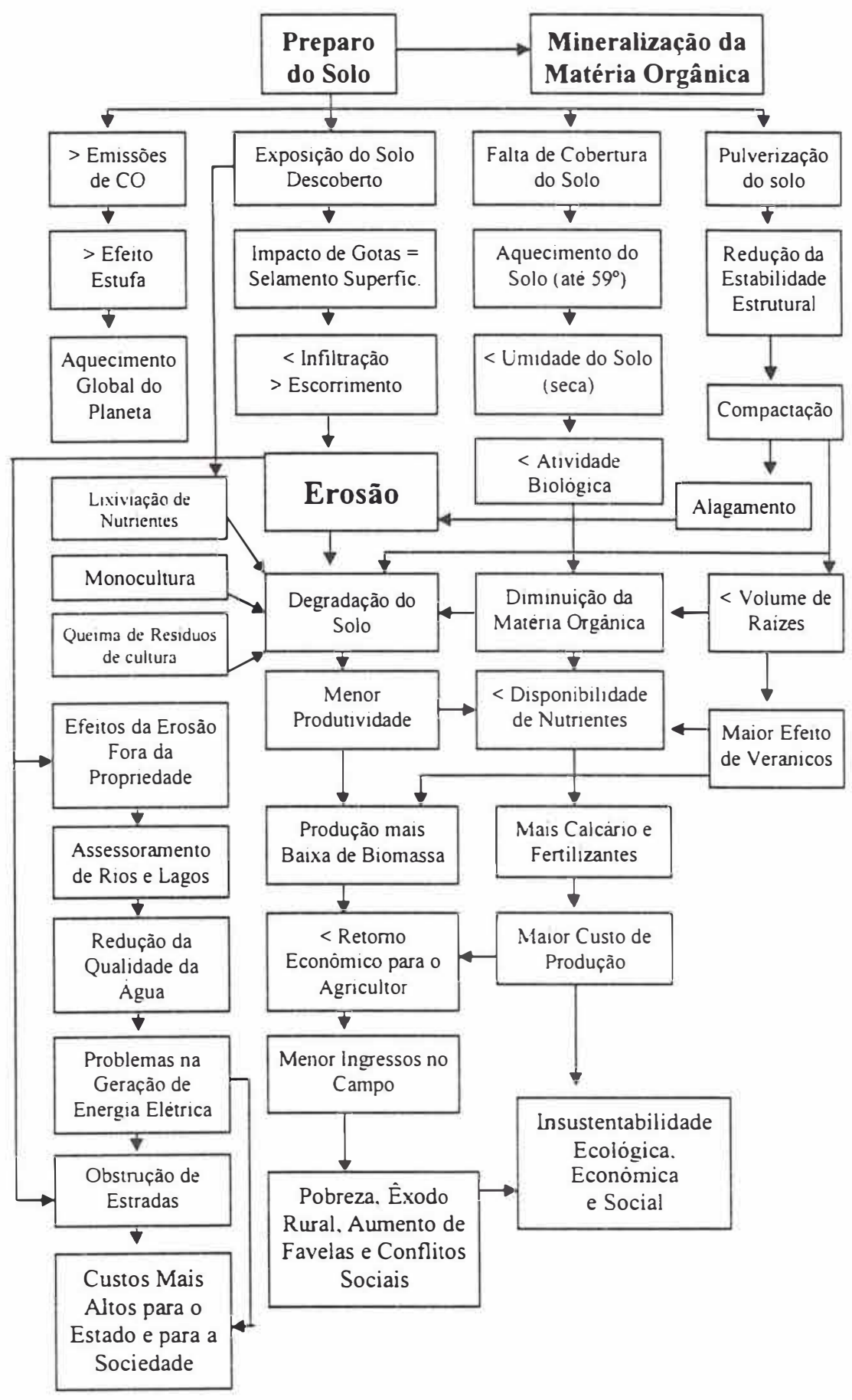

Figura 1. Conseqüências do preparo inadequado do solo sobre a degradação e perda da produtividade (Derpsch, 1997b). 
Nas condições tropicais, as culturas não produzem satisfatoriamente em solos adensados e compactados por estes não oferecerem condições exigidas para a absorção de água e nutrientes em presença de temperatura elevada (Primavesi, 1990).

\subsection{Plantio direto: evolução e economicidade}

Devido às inúmeras vantagens comparativas, a evolução na adoção do sistema de plantio direto por agricultores de todo o planeta tem sido bastante representativa. Estima-se que em todo o mundo sejam cultivados mais de 40 milhões de hectares com este sistema, sendo os Estados Unidos a área representativa, com 15 milhões de hectares (Hebblethwaite, 1997). Segundo Derpsch (1997b), os países que compõem - Mercosul cultivam cerca de 10 milhões de hectares no sistema de plantio direto.

No Brasil, o plantio direto começou a ser implementado em 1972, em Londrina-PR (Derpsch, 1972 citado por Derpsch, 1984). Segundo Balbino et al. (1996), a área com plantio direto no Brasil em 1978/79 era de 200 mil hectares, não havendo até este período, nenhuma experiência no cerrado, a qual iniciou-se na safra 1981/82, com menos de 500 hectares. Dez anos mais tarde, o Brasil contava com 1.250 mil hectares e o cerrado com cerca de 200 mil hectares. Na safra 1995/96 o Brasil já dispunha de 4,5 milhões de hectares e o cerrado com 1,4 milhões com o sistema de plantio direto. 
Segundo Muzilli (1981a), as razões para a adoc̣ão deste sistema, são, em ordem decrescente de prioridade: controle da erosão; ganho de tempo para o plantio; economia de combustível; melhor estabelecimento da cultura; maior retenção de água no solo; economia de mão-de-obra e economia em máquinas e implementos.

A economicidade do plantio direto, bem como dos demais sistemas de manejo do solo deve levar em conta, sobretudo, a relação benefício/custo, enfatizando-se a importância de considerar os rendimentos das culturas. De forma quase generalizada, a literatura faz menção à economicidade dos diversos sistemas apenas considerando o uso de máquinas ou o consumo de combustível. Landers (1995a) salienta que apesar da redução na força trativa em cerca de $44 \%$ no plantio direto, ocorre um ligeiro aumento no custo de produção da soja e do milho. Porém, o consumo de combustível, os investimentos em maquinário e a força trativa em HP/ha no plantio direto, em relação ao sistema convencional, são reduzidos em $74 \%, 54 \%$ e $49 \%$, respectivamente.

Balbino (1997) relatou que para se preparar 1 ha no plantio direto são gastos cerca de 40 minutos, enquanto no convencional são necessárias entre 6 e 7 horas de máquinas mais implementos. Seguy \& Bouzinac (1993), em estudos conduzidos no Médio-Norte do Mato Grosso, concluíram serem necessárias 4,3 horas para o preparo do solo com arado de aivecas. Em relação a este implemento, foram observadas reduções de $16 \%, 28 \%$ e até $63 \%$ para os preparos com grade aradora, escarificação profunda e plantio direto, respectivamente. Silveira et al. (1983), relataram que o consumo de combustível no sistema de plantio direto foi entre 2,4 e 3,2 vezes inferior aos sistemas de subsolagem, grade aradora e arado de disco. 
Gentil (1995) concluiu que se toda a área utilizada para a produção de grãos no Brasil fosse conduzida no sistema de plantio direto, a necessidade de tratores seria 58\% menor e haveria redução no consumo de combustivel e peças da ordem de $74 \%$ e $63 \%$, respectivamente. Ainda de acordo com este autor, os investimentos em mecanização para o plantio direto são $47 \%$ inferiores àqueles necessários nos sistemas convencionais.

\subsection{Cobertura morta e cobertura do solo no plantio direto}

A formação e manutenção da cobertura morta nos trópicos, com destaque para o cerrado, foram alguns dos principais obstáculos encontrados para o estabelecimento do plantio direto. Altas temperaturas associadas a adequada umidade promovem a rápida decomposição dos resíduos vegetais incorporados ao solo (Sanchez \& Logan, 1992) e, presumivelmente, também dos mantidos na superfície do terreno. A experiência tem mostrado que neste bioma, o cultivo do milheto para formação da cobertura morta, principalmente na agricultura de sequeiro, foi o que permitiu o grande impulso na adoção do plantio direto. Seu cultivo é geralmente feito no final ou na entrada do período chuvoso.

A cobertura morta resultante dos restos culturais e/ou plantas daninhas geralmente são insuficientes para a plena cobertura do solo, podendo comprometer a eficiência do plantio direto. Saraiva \& Torres (1997) relataram que os restos culturais resultantes da colheita da soja não são suficientes para a cobertura total do solo, considerando ainda a rápida decomposição deste resíduo. Por outro lado, restos culturais de gramíneas como o milho, trigo e aveia são capazes de cobrir toda a superfície do 
terreno. Quando mantidos na superfície, Seguy et al. (1992b) relataram que no Estado do Mato Grosso, no período de 90 dias após a primeira chuva, as palhadas de milho, arroz e soja foram reduzidas em $63 \%$, $65 \%$ e $86 \%$ respectivamente, de seu peso inicial, e, nesta mesma ordem, promoveram aos 90 dias, cobertura de solo de $30 \%$, 38\% e $7 \%$.

Em regiões com clima mais ameno, como no Paraná, as palhadas de milho e aveia são decompostas mais lentamente. A palha de milho é reduzida para $51 \%$ do seu peso seco em 150 dias e a de aveia preta em 29\% em 179 dias (Wisniewski \& Holtz, 1997). Lopes et al. (1987) e Saraiva \& Torres (1993) encontraram que 1, 2 e 4 t/ha de matéria seca de cobertura vegetal cobrem cerca de $20 \%, 40 \%$ e $60-70 \%$ da superfície do solo, respectivamente. Acima de 7 t/ha a quase totalidade da superfície do terreno fica protegida.

São necessários ainda mais estudos sobre este tema no cerrado, já que a perenização do sistema de plantio direto é dependente da boa proteção da superfície do solo, sem a qual muitas das vantagens do sistema podem deixar de existir em toda sua plenitude. Vale ressaltar que na agricultura irrigada do cerrado praticamente não se cultivam espécies exclusivas para formação de cobertura morta, e na de sequeiro, esta é muitas vezes baseada nos restos culturais provenientes dos cultivos de safrinha, principalmente de sorgo e milho.

\subsection{Manejo do solo e algumas características físicas}

A compactação do solo traz como conseqüências, mudanças bruscas nas relações solo-ar-água, principalmente nos processos dinâmicos, 
tais como: movimentação da água, ar e nutrientes; crescimento radicular das plantas e na difusibilidade térmica ao longo do perfil (Canalli \& Roloff, 1997; Pauletto et al., 1997). As características físicas do solo são interdependentes, com isto a modificação de uma delas, normalmente leva à modificação de todas as outras (Vieira, 1985). Por outro lado, a compactação do solo é um conceito complexo e uma propriedade de difícil descrição e mensuração. Está intimamente relacionada com as propriedades físicas, químicas e biológicas do solo, que, reconhecidamente, são importantes no desenvolvimento das plantas. O uso indiscriminado de implementos que revolvem o solo superficialmente, caso das grade pesadas, causa, sistematicamente, a compactação da camada subsuperficial do solo (Seguy et al., 1984).

Da mesma forma, a utilização continuada do plantio direto pode resultar em aumento da massa específica do solo em alguma (Torres et al., 1995b), ou em todas as profundidades, reduzindo, principalmente, a porosidade (Hill, 1990). Mesmo nos sistemas de manejo onde não se faz a movimentação do solo, caso do plantio direto, ocorre compactação com conseqüente redução nos valores de macroporosidade e aumento da massa específica do solo e microporosidade, pelo trânsito de máquinas nas operações de pulverização, plantio e colheita (Vieira, 1981; Vieira \& Muzilli, 1984; Corrêa, 1985; Castro, 1989). Wagger \& Denton (1989) destacam que a massa específica do solo no sistema de plantio direto é sempre maior na posição onde passam as rodas do maquinário agrícola, reduzindo a porosidade em cerca de $21 \%$ e, com o tempo, tende a aumentar também nas posic̣ões não trafegadas.

Aumento na massa específica do solo e microporosidade e redução na macroporosidade e porosidade total no plantio direto foram 
também observados por Vieira (1985). Vieira \& Muzilli (1984), observaram que os valores de densidade de um Latossolo Vermelho-Escuro, sob diferentes sistemas de manejo, foram significativamente maiores a $10 \mathrm{~cm}$ de profundidade no sistema de plantio direto, inexistindo diferenças nas camadas inferiores a $20 \mathrm{~cm}$. A porosidade total e macroporosidade também foram mais baixas no plantio direto em relação ao manejo convencional.

Corrêa (1985) verificou no plantio direto, em relação ao manejo convencional e enxada rotativa, maior adensamento e menores valores de macroporosidade e porosidade total na camada superficial, 0-10 cm. Derpsch et al. (1991), estudaram o efeito de diferentes manejos em Latossolo Roxo e verificaram que a massa específica do solo foi maior, no caso do plantio direto, na camada $0-20 \mathrm{~cm}$, enquanto que no preparo convencional, maiores densidades do solo estavam localizadas no perfil 20$30 \mathrm{~cm}$ de profundidade.

Moreira et al. (1995) estudaram diferentes manejos de solo em área irrigada por pivô central, num Latossolo Vermelho-Amarelo, verificando que a massa específica do solo também foi superior no plantio direto na camada 0-10 cm, comparativamente à grade aradora e ao arado de aivecas. Neste estudo, os autores verificaram também a redução da porosidade total no sistema de plantio direto, consequência da redução da macroporosidade.

Alguns estudos têm demonstrado não haver diferenças significativas na massa específica do solo entre os sistemas convencional e direto (Fernandes et al., 1983; Albuquerque et al., 1995).

Segundo Fernandes et al. (1983) e Reeves (1995), a massa específica do solo no sistema de plantio direto pode vir a diminuir com o passar dos anos, em parte, pelo aumento do conteúdo da matéria orgânica, favorecendo a melhoria da estrutura do solo. Por outro lado, os sistemas de 
manejo com maior mobilização do solo, tais como escarificação e preparo convencional com arado de discos, apresentam menores valores de massa específica do solo, maior macroporosidade e porosidade total em relação ao plantio direto (Oliveira et al., 1990; Ros et al., 1997).

Reeves (1995) relatou que práticas de manejo do solo influenciam as condições físicas, principalmente pelo efeito da matéria orgânica, cujo aumento, característica do plantio direto, influencia tanto as propriedades físicas como químicas e biológicas do solo. No processo de decomposição dos resíduos orgânicos, os microrganismos excretam substâncias que agregam as partículas do solo, resultando em menor densidade e compactação. No plantio direto, a relativa manutenção das propriedades físicas do solo é feita, tanto pela atividade biológica como pelos canais das raízes. Balbino (1997) mencionou que o maior adensamento das camadas subsuperficiais do solo mantido sob plantio direto é, muitas vezes, compensado pela continuidade dos poros resultantes da atividade biológica e da decomposição das raízes.

Outro ponto relevante é que a compactação do solo pode afetar a absorção de nutrientes através da modificação no crescimento radicular das plantas e na disponibilidade de nutrientes. Phillips \& Kickham (1962) observaram que a presença de camada compactada pode reduzir em até $25 \%$ a absorção de N, P e K pelas plantas de milho. Borges et al. (1988) concluíram que a compactação do solo reduziu o acúmulo de $\mathrm{P}, \mathrm{K}, \mathrm{Ca}$ e $\mathrm{Mg}$ na parte aérea de plantas de soja. Para os três primeiros nutrientes, o acúmulo foi máximo até a massa específica do solo da ordem de $1.0 \mathrm{~g} / \mathrm{cm}^{3}$.

Algumas leguminosas como o feijão-de-porco e feijão bravo também mostraram redução no acúmulo de $\mathrm{Ca}, \mathrm{K}$ e $\mathrm{P}$ em solo compactado (Alvarenga et al., 1995). Para a cultura do feijão, Primavesi et al. (1985) 
concluíram que a compactação reduziu a extração de $\mathrm{Ca}, \mathrm{P}$ e $\mathrm{N}$ em um Latossolo Roxo e de K num Podzólico, havendo, contudo, aumentos na concentração foliar de $\mathrm{Mg}, \mathrm{Ca}$ e $\mathrm{N}$.

Outro aspecto importante relacionado ao manejo do solo é a estabilidade dos agregados.

O uso intensivo dos Latossolos de cerrado, com práticas de manejo inadequadas, têm causado a desagregação estrutural do solo, evidenciada pela diminuição do conteúdo da matéria orgânica e redução do tamanho dos agregados (Vieira \& Muzilli, 1984; Derpsch et al., 1991; Campos et al., 1995). No sistema de plantio direto, a cobertura vegetal e os resíduos orgânicos protegem os agregados da superfície do solo contra a desagregação devida ao impacto das chuvas. Além disto, os sub-produtos derivados da decomposição da matéria orgânica funcionam como agentes de formação e estabilização dos agregados (Harris et al., 1966). Assim, Vieira \& Muzilli (1984), Carpenedo \& Mielniczuk (1990), Derpsch et al. (1991), Resck et al. (1995) e Campos et al. (1995) verificaram que, no

plantio direto, ocorreu o maior percentual de agregados maiores, bem como com maior estabilidade em água, em relação aos manejos que revolvem o solo.

\subsection{Alguns aspectos biológicos do solo}

A manutenção da palhada na superfície do terreno no sistema de plantio direto, dentre os muitos benefícios, é fonte de energia para os microrganismos e para a mesofauna do solo, ativando suas ações. Nas 
microrganismos e para a mesofauna do solo, ativando suas ações. Nas condições tropicais a atividade biológica é ainda mais intensa, com enorme diversidade de espécies de organismos. Segundo Gassen \& Gassen (1996), estima-se que a mesofauna movimenta até $20 \%$ do solo em ambientes naturais, enquanto as raízes são responsáveis por cerca de $80 \%$ da movimentação biológica do solo. No processo de abertura das galerias pela fauna, ocorre, geralmente, a deposição de resíduos orgânicos nas câmaras, que, após decompostas e mineralizadas, melhoram as propriedades do solo. Neste contexto, o plantio direto com manutenção da cobertura sobre a superfície do solo traz benefícios incontestáveis.

Ainda que o microclima úmido, com menor amplitude de variação de temperatura na camada protegida pela palhada, favoreça o desenvolvimento de fungos, bactérias, insetos predadores e parasitóides e decompositores de resíduos orgânicos (Gassen \& Gassen, 1996), uma das desvantagens da cobertura morta constitui-se na possibilidade de sobrevivência de patógenos das plantas cultivadas.

Doenças da parte aérea, cuja fonte primária de inóculo consiste nos restos culturais, aumentam sua incidência no plantio direto (Costa, 1997d). Ainda segundo este autor, os agentes causais de doenças do solo, oportunistas por natureza, são favorecidos, em primeira instância, em termos de aumento de inóculo, com o aumento do carbono do solo. Segundo Costa (1997c), se o plantio direto for iniciado numa área com alta incidência de doenças causadas por fungos do solo, através do aumento da matéria orgânica, ocorre o favorecimento da atividade microbiológica total do solo. Simultaneamente são beneficiados os patógenos e outros habitantes naturais do solo. Assim, nos primeiros anos de plantio direto, poderá haver favorecimento às doenças, tal como Rhizoctonia solani e, 
principalmente sob palhada de milho, de Fusarium solani. Ainda segundo este autor, os escleródios de Sclerotinia sclerotiorum podem ser facilmente colonizados por antagonistas do solo, originários ou favorecidos pela matéria orgânica. A cobertura morta pode servir também de barreira à germinação de apotécios, sendo que neste caso, o plantio direto desfavorece a ocorrência de doenças.

A eliminação dos restos culturais através da incorporação profunda com aração tem sido recomendada como uma das medidas de controle de Sclerotinia sclerotiorum, Thanatephorus cucumeris, Macrophomina phaseolina, Rhizoctonia solani e Fusarium solani na cultura do feijão (Cardoso et al., 1996; Costa 1997a; Costa \& Silveira 1997), Septoria glycines, Cercospora kikuchii, Diaphorte phaseolorum, na cultura da soja (EMBRAPA, 1996), e Helminthosporium turcicum, $H$. maydis, $H$. carbonum, Diplodio maydis e Fusarium moniliforme, na cultura do milho (EMBRAPA, 1997b). É evidente que tais recomendações foram originadas em ambientes onde se praticava a agricultura convencional, possivelmente com enormes desequilíbrios biológicos. 0 restabelecimento destes equilíbrios no sistema de plantio direto, aliado à massificação do uso de defensivos agrícolas, particularmente nos cultivos irrigados, pode conter a agressividade de alguns patógenos das plantas. Contudo, ainda são incipientes os estudos e o entendimento da atividade microbiológica, nociva ou não às plantas cultivadas, no sistema de plantio direto, em especial em regiões tropicais e sistemas intensivos de uso da terra. 


\subsection{Comportamento dos nutrientes no solo em função do manejo e resposta das culturas à adubação}

O plantio direto, em relação à ciclagem biológica, tende à máxima conservação de nutrientes em um agroecossistema. O mínimo revolvimento do solo e a manutenção da palhada reduzem as perdas de nutrientes (Wisniewski \& Holtz, 1997). Contudo, o plantio direto não recupera propriedades químicas de solos, que nos trópicos são naturalmente deficientes ou degradadas por mau manejo. Solos lixiviados, pobres e ácidos, como os do cerrado, necessitam de correção antes do estabelecimento do plantio direto (Shaxson, 1995). Por não ser recuperador das limitações do solo, é necessária, antes da implantação do sistema, a correção das propriedades físicas e químicas no perfil (Derpsch, 1984; Landers, 1995a; Balbino et al., 1996).

Balbino et al. (1996) observam que para o plantio direto se desenvolver sem problemas de fertilidade do solo, é necessário que o perfil mais intensamente explorado pelas raízes contenha mais de $2 \%$ de matéria orgânica; $\mathrm{pH}$ (água) 5,$5 ; 2 \mathrm{cmol}^{\mathrm{c}} / \mathrm{kg}$ de $\mathrm{Ca} ; 0.8 \mathrm{cmol}^{\mathrm{c}} / \mathrm{kg}$ de $\mathrm{Mg} ; 20 \mathrm{mg} / \mathrm{kg}$ de $P ; 50 \mathrm{mg} / \mathrm{kg}$ de $\mathrm{K} ; 1 \mathrm{mg} / \mathrm{kg}$ de $\mathrm{B}$ e Cu; $5 \mathrm{mg} / \mathrm{kg}$ de $\mathrm{Mn} ; 4 \mathrm{mg} / \mathrm{ha}$ de $\mathrm{Zn} \mathrm{e}$ $0,2 \mathrm{mg} / \mathrm{kg}$ de Mo. Nas regiões tropicais, contudo, é difícil atingir tais níveis para todos os nutrientes em pouco tempo e a custos compatíveis com o retorno das colheitas, sendo necessário acumulá-los no perfil ao longo do tempo, através de excedentes na adubação de manutenção.

Mullins (1995) recomenda que para solos ácidos e inférteis, típicos do cerrado, deve se proceder tanto a calagem como a correção potássica e fosfatada em maior profundidade até pelo menos a zona de maior atividade radicular. Balbino (1997) recomenda, inclusive, que solos 
com fertilidade natural baixa, devem ser cultivados por 2 ou mais anos no sistema convencional, incorporando assim os corretivos e alguns nutrientes no perfil. Esta prática é de fundamental importância para os nutrientes imóveis no solo e no floema das plantas, caso do Ca. Já que o uso intensivo da área, seja para produção de grãos ou cobertura morta, é uma das prerrogativas do plantio direto, e as freqüentes adubações são feitas na camada superficial, é evidente que, em conseqüência, haja um acúmulo dos nutrientes na profundidade de adubação, principalmente aqueles menos móveis ou imóveis.

Sá (1993) avaliou a distribuição de nutrientes no perfil do solo mantido sob plantio direto durante 4 a 16 anos, verificando que em todos os casos o teor de $P$ abaixo de $20 \mathrm{~cm}$ de profundidade era menor que 3 $\mathrm{mg} / \mathrm{kg}$, sendo similar aos valores encontrados em solos sob vegetação nativa. A prática contínua do plantio direto por 4, 9 e 16 anos, resultou no acúmulo de cerca de 29, 79 e $129 \mathrm{mg} / \mathrm{kg}$ de $\mathrm{P}$, respectivamente, na camada 0-2,5 cm. De maneira similar, o $\mathrm{K}$ concentrou-se na camada 0-10 $\mathrm{cm}$, atingindo valores de até $4.5 \mathrm{cmol}^{\mathrm{c}} / \mathrm{kg}$. Resultados semelhantes foram relatados por Muzilli (1983, 1984); Mullins (1995); Pauletti et al. (1995); Franzluebbers \& Hons (1996). Também foi verificado o acúmulo superficial, principalmente até a profundidade de $10 \mathrm{~cm}$, de Ca e Mg (Muzilli, 1983; Pauletti et al., 1995), e Zn e Mn (Franzluebbers \& Hons, 1996). Segundo estes últimos autores, sob plantio direto ocorre menor concentração de Fe e $\mathrm{Cu}$ nos $5 \mathrm{~cm}$ superficiais do solo. Ainda segundo a maioria destes autores, no manejo convencional do solo ocorre a diluição destes nutrientes no perfil.

A maior acidez superficial no sistema de plantio direto é ponto de controvérsias na literatura. Enquanto Dick (1983) relatou que o $\mathrm{pH}$ do solo é ligeiramente inferior nas camadas superficiais, outros autores não observaram a mesma relação (Guedes, 1978; Muzilli, 1983; Ismail et al., 
1994; Pauletti et al., 1995). Também é evidente, no plantio direto, a maior concentração de matéria orgânica na superfície (Ismail et al., 1994; Pauletti et al., 1995). Em relação aos demais métodos de manejo do solo, a escarificação tende a acumular os nutrientes no solo de forma similar ao plantio direto, e as grades e arados tendem a uniformizar a distribuição até a profundidade trabalhada.

Enquanto que para Muzilli (1984), no manejo convencional do solo, o maior contato do adubo com as partículas do solo explica a menor disponibilidade de nutrientes para as culturas, para Mallarino (1997), o acúmulo superficial de nutrientes pode resultar em baixa absorção de $P$ e $K$, e, conseqüentemente, baixos rendimentos de colheita, especialmente quando a camada superficial do solo estiver seca. Na prática da agricultura dependente das chuvas, particularmente nos trópicos, com freqüente ocorrência de veranicos, parece ser necessária uma melhor qualidade das propriedades do solo, em maior profundidade, em relação às regiões temperadas, objetivando obter melhor desenvolvimento radicular das plantas e, conseqüentemente, melhor uso da água.

Barber (1985) mencionou que quando o fertilizante fosfatado foi misturado em apenas uma pequena porção de solo, ocorreu grande proliferação de raízes na porção fertilizada em relação às demais, podendo neste caso, ter sido reduzida a absorção do nutriente. Guimarães \& Castro (1981, 1982) e Chaib et al. (1984) verificaram melhor desenvolvimento radicular do feijoeiro no que se refere à profundidade, quando se efetuou a adubação em maior profundidade em relação à convencional. Aumento no rendimento de grãos devido a incorporação mais profunda do fertilizante tem sido registrado na cultura do feijão (Kluthcouski et al., 1982; Thung et al., 1982) e milho (Barber, 1985; Alonço \& Ferreira, 1992). Schenk \& 
Barber (1980) e Silderbush \& Barber (1984) relatam que a maior parte do fósforo e potássio é extraída da camada $0-20 \mathrm{~cm}$ de profundidade. Mallarino (1997) salientou que a adubação potássica mais profunda foi particularmente importante em anos que ocorreu deficiência hídrica. Gonzales-Erico et al. (1979) e Alonço \& Ferreira (1992) obtiveram maıres produtividades de milho com a incorporação profunda do calcário. Sá (1995) também registrou efeitos positivos da calagem profunda nas culturas da soja e do milho, principalmente quando a incorporação do corretivo foi realizada com arado de aivecas, até a profundidade de $35 \mathrm{~cm}$.

A resposta das culturas à adubação fosfatada e potássica depende, acima de tudo, do nível de correção prévia destes nutrientes no solo. Assim, em áreas que foram cultivadas adequadamente por médio e longo periodo de tempo, registram-se, na maioria dos casos, maior concentração de nutrientes no solo e, conseqüentemente, resposta a níveis menores de adubação. Para a cultura do milho, sob plantio direto, Bordoli \& Mallarino (1998) observaram respostas à adubação fosfatada quando o $P$ no solo encontrava-se abaixo de $10 \mathrm{mg} / \mathrm{kg}$, no perfil de $0-7,5 \mathrm{~cm}$, não sendo observada resposta à adubação potássica. Em outro estudo, Mallarino (1997) observou que quando o solo continha mais de $16 \mathrm{mg} / \mathrm{kg}$ de $P$ e entre 91 e $130 \mathrm{mg} / \mathrm{kg}$ de $\mathrm{K}$, houve tendência ao aumento no rendimento do milho com a aplicação de, no máximo, 30 e $35 \mathrm{~kg}$ de $\mathrm{P}_{2} \mathrm{O}_{5}$ e $\mathrm{K}_{2} \mathrm{O}$, respectivamente.

Resultados semelhantes foram obtidos por Pöttker (1997), o qual não verificou resposta do milho à adubação fosfatada quando o $P$ no solo era superior a $13.6 \mathrm{mg} / \mathrm{kg}$ e o solo continha $43 \%$ de argila. Em solo mais argiloso (63\%), este autor verificou resposta significativa de soja a adubação fosfatada quando o $P$ no solo estava em torno de $4,3 \mathrm{mg} / \mathrm{kg}$. 
Ainda para o milho, Sá (1997), em três anos consecutivos de plantio direto, observou resposta da cultura apenas no primeiro ano, para a dosagem de 30 $\mathrm{kg} / \mathrm{ha}$ de $\mathrm{P}_{2} \mathrm{O}_{5}$. Em solos com média e baixa disponibilidade de $P$, as respostas à adubação fosfatada ocorreram até a dosagem de $60 \mathrm{~kg} / \mathrm{ha}$ de $\mathrm{P}_{2} \mathrm{O}_{5}$, enquanto que para a soja as respostas ocorreram para dosagens de no máximo $30 \mathrm{~kg} / \mathrm{ha}$ de $\mathrm{P}_{2} \mathrm{O}_{5}$. Kochhann \& Denardin (1997) não observaram efeito significativo da adubação fosfatada sobre o rendimento da soja em solo que apresentava 13 a 33,10 a 16 , e 10 a $13 \mathrm{mg} / \mathrm{kg}$ de $P$ nas camadas 0-5, 5-10 e 10-20 cm de profundidade, respectivamente. Raij et al. (1981) também não encontraram respostas da cultura do milho à adubação fosfatada e potássica quando o solo apresentava altos teores destes nutrientes. Oliveira \& Cassol (1995) obtiveram maiores produtividades da soja, 3,6 t/ha de grãos, em solo que continha 1,$83 ; 0,74 ; 49 ; 3,04$ e 0,24 $\mathrm{mg} / \mathrm{kg}$ de $\mathrm{Zn}, \mathrm{Cu}, \mathrm{Fe}, \mathrm{Mn}$ e $\mathrm{B}$, respectivamente.

Fageria et al. (1988), avaliaram 25 cultivares de arroz em solos com diferentes condições de $P$, os quais continham 1,5 e $5,0 \mathrm{mg} / \mathrm{kg}$ de $P$, e observaram, para a maioria deles, que houve pouca diferença no rendimento de grãos entre as duas situações. Estes autores relataram ainda que 0 arroz de terras altas responde menos à adubação potássica que o irrigado. Em outro estudo, Fageria et al. (1995), avaliando 19 cultivares de arroz de terras altas de ciclo médio e 10 de ciclo curto, em solo com 2,2 e $61 \mathrm{mg} / \mathrm{kg}$ de $\mathrm{P}$ e K, verificaram que os cultivares precoces responderam à aplicação de até $60 \mathrm{~kg} / \mathrm{ha}$ de $\mathrm{P}_{2} \mathrm{O}_{5}$, enquanto os de ciclo médio, em geral, além de não responderem, sofreram, em alguns casos, ligeiro decréscimo de rendimento no nível mais alto de $\mathrm{P}_{2} \mathrm{O}_{5}, 60 \mathrm{~kg} / \mathrm{ha}$. Estes autores concluíram que existem diferenças significativas no comportamento de genótipos de arroz, na produção de grãos, para um determinado nível de fertilidade do solo. 


\subsection{Suficiência de nutrientes nas plantas e exportação pelas colheitas}

De acordo com Oliveira et al. (1996), a colheita de um hectare de feijão, com aproximadamente 250 mil plantas, retira do solo $102 \mathrm{~kg} \mathrm{de}$ $\mathrm{N}, 9 \mathrm{~kg}$ de P, $93 \mathrm{~kg}$ de K, $54 \mathrm{~kg}$ de $\mathrm{Ca}, 18 \mathrm{~kg}$ de $\mathrm{Mg}$ e $25 \mathrm{~kg}$ de S. Cada tonelada de grãos exporta cerca de $35 \mathrm{~kg}, 4 \mathrm{~kg}, 15 \mathrm{~kg}, 3 \mathrm{~kg}, 3 \mathrm{~kg}$ e $6 \mathrm{~kg}$ desses mesmos nutrientes, na mesma ordem. Em relação ao $P$ e $K$, objeto do presente estudo, os registros de exportação variam bastante na literatura, principalmente devido a alta diversidade observada nos rendimentos. Em geral, as exportações destes nutrientes em uma tonelada de grãos variam em cerca de 2,2 a 4,0 kg de P e 14 a $22 \mathrm{~kg}$ de K (Gallo \& Miyasaka, 1961; Haag et al., 1967; Cobra Neto et al., 1971).

Para a cultura do milho, a extração de nutrientes também é variável, dependendo principalmente do rendimento obtido. Para rendimentos entre 5,8 e 7,9 t/ha, são extraídos do solo, em um hectare, entre 100 e $167 \mathrm{~kg}$ de N, 19 e $33 \mathrm{~kg}$ de $\mathrm{P}, 95$ e $113 \mathrm{~kg}$ de $\mathrm{K}, 17$ e $27 \mathrm{~kg}$ de $\mathrm{Ca}$ e 17 e $25 \mathrm{~kg}$ de $\mathrm{Mg}$. As exportações por tonelada de grãos, nesta mesma ordem, variam de 17,2 e $21,2 \mathrm{~g}, 3,3$ e $4,2 \mathrm{~kg}, 14,4$ e 16,3 kg, 2,9 e $3,4 \mathrm{~kg}$ e 2,9 e $3,2 \mathrm{~kg}$ (Coelho \& França, 1995). Especificamente para P e $K$, são observadas na literatura exportações variando entre 3,1 e 4,7 kg de $P$ e 3,3 e 13,4 kg de $K$ por tonelada de grãos (Barber \& Olson, 1968; Malavoita et al., 1974; Hiroce et al., 1989; Büll, 1993).

Para a produção de uma tonelada de grãos e uma tonelada de matéria seca, a soja extrai do ambiente cerca de $83 \mathrm{~kg}$ de $\mathrm{N}, 6,7 \mathrm{~kg}$ de $P$, $31.5 \mathrm{~kg}$ de $\mathrm{K}, 12,2 \mathrm{~kg}$ de $\mathrm{Ca}$ e $6,7 \mathrm{~kg}$ de $\mathrm{Mg}$, sendo exportados, por tonelada de grãos, $51 \mathrm{~kg}$ de $\mathrm{N}, 4,37 \mathrm{~kg}$ de $P, 16,6 \mathrm{~kg}$ de $\mathrm{K}, 3 \mathrm{~kg}$ de Ca e 
$2,0 \mathrm{~kg}$ de $\mathrm{Mg}$ (EMBRAPA, 1996). Para o P e K, algumas literaturas mostram exportações, por tonelada de grãos, variáveis entre 2,8 e $4,6 \mathrm{~kg}$ de $P$ e 11,3 e 19,3 kg de K (Tanaka et al., 1993; Lazarini et al., 1995).

Para o arroz de terras altas, com produção entre 4.8 e 6.6 ton de grãos e matéria seca da parte aérea, respectivamente, são extraídos do solo cerca de 159,4 $\mathrm{kg}$ de $\mathrm{N}, 13,3 \mathrm{~kg}$ de P, $189 \mathrm{~kg}$ de $\mathrm{K}, 29,9 \mathrm{~kg}$ de Ca e $24,1 \mathrm{~kg}$ de $\mathrm{Mg}$ (Fageria et al., 1997). As exportações de $\mathrm{P}$ e $\mathrm{K}$ por tonelada de grãos de arroz variam entre 1,7 e 3,5 kg de $P$ e 2,3 e 3,3 kg de $K$ (Malavolta, 1967; Ohno \& Marur, 1977).

Os níveis adequados dos macro e micronutrientes nas folhas de soja, milho, feijão e arroz de terras altas são apresentados na Tabela 2.

\subsection{Manejo do solo e desenvolvimento radicular das plantas}

As alterações nas propriedades do solo, devidas ao manejo, afetam profundamente o desenvolvimento radicular das plantas. As raízes, contudo, são menos conhecidas, menos estudadas, menos entendidas e menos apreciadas dentre as partes da planta pelo fato de não poderem ser vistas, e ainda pelas dificuldades para o seu estudo (Hughes et al., 1992). As raízes absorvem e translocam água e nutrientes, sintetizam carboidratos e suportam a planta. De acordo com Miller (1986), estas funções são afetadas por estresses aos quais as raízes podem estar sujeitas, tais como: falta ou excesso de água; deficiência de $\mathrm{O}_{2}$; deficiência ou desequilíbrio de nutrientes; temperaturas adversas; impedimento físico; presença de elementos tóxicos e ataque de insetos e doenças. Na agricultura de 


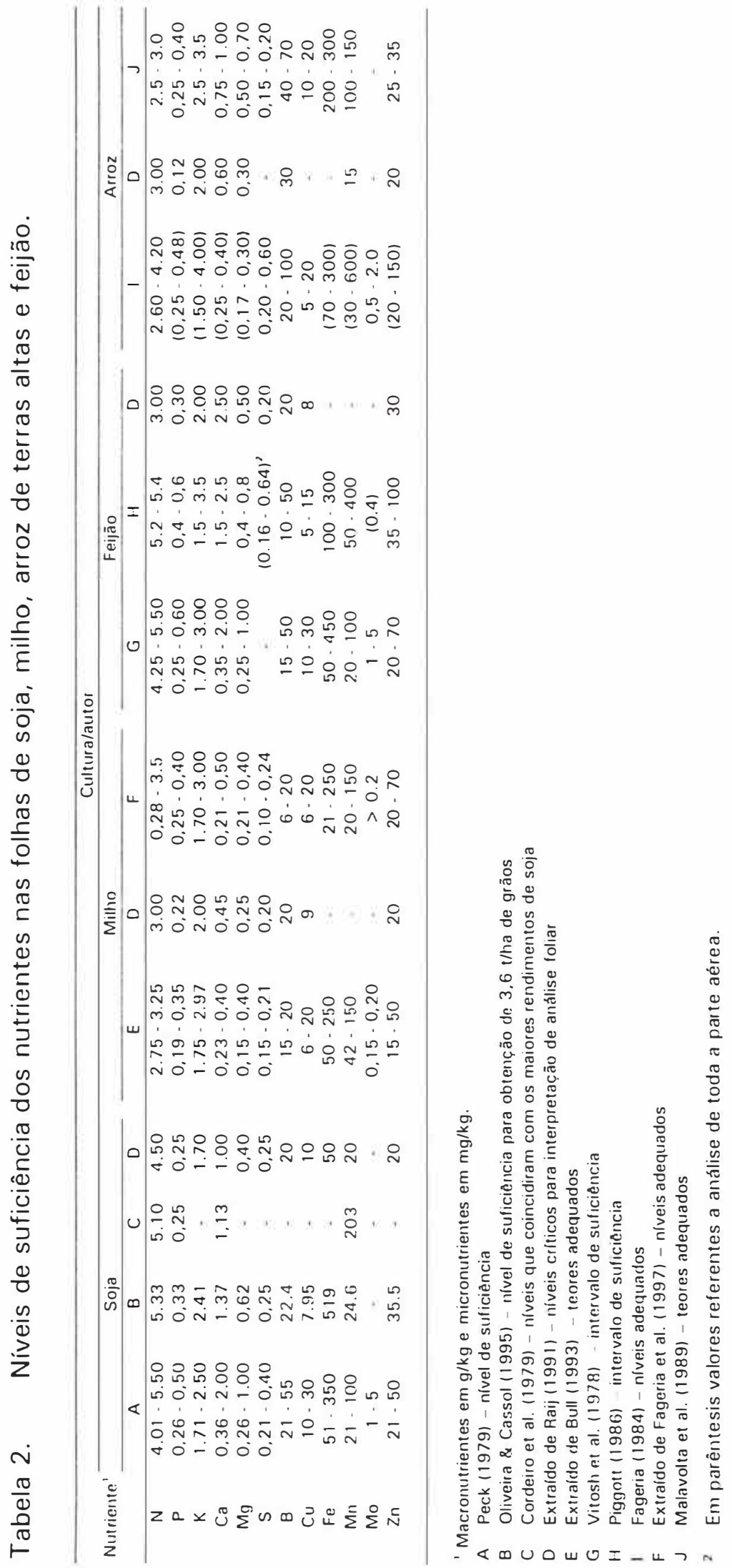


sequeiro, principalmente em regiões sujeitas a curtos períodos de estresse hídrico, é desejável o desenvolvimento profundo das raízes. Já para a agricultura irrigada e intensamente fertilizada, o sistema radicular profundo pode ser indesejável, devido à demanda extra de fotoassimilados.

Aumentos nos níveis de adubação, principalmente localizada, têm resultado na redução do desenvolvimento de raízes de soja (Roder et al., 1989), do arroz de terras altas irrigado suplementarmente por aspersão (Stone \& Pereira, 1994a), do milho (Nanagara et al., 1976) e do feijão (Stone \& Pereira, 1994b).

Submeter as plantas ao estresse hídrico após a emergência tem sido bastante contraditório, já que os resultados obtidos com esta prática têm sido inconsistentes (Robertson et al., 1980; Newell \& Wilhelm, 1987; Guimarães et al., 1996).

O excesso de umidade no solo, por outro lado, tem sido prejudicial ao crescimento das raízes em profundidade, nas plantas de soja (Stanley et al., 1980), feijão (Azevedo et al., 1993), milho (Mackay \& Barber, 1985), e arroz de terras altas (Seguy \& Bouzinac, 1993). Ainda assim, o impedimento causado por camadas de solo compactadas tem sido o principal fator que influencia o alongamento e proliferação das raízes (Tu \& Tan, 1991). Sob compactação, a massa específica do solo aumenta e a porosidade diminui, principalmente em relação aos macroporos. As raízes não conseguem reduzir seu diâmetro para penetrar nos microporos menores que as suas extremidades (Wiersum, 1957 citado por Marchner, 1986). Neste caso, as raízes têm que deslocar as partículas de solo, sendo que a força necessária rapidamente se esgota e o alongamento das raízes é restringido (Marchner, 1986). 
Da mesma forma que os diferentes manejos afetam as propriedades do solo, via de regra, também afetam o desenvolvimento radicular das culturas. Primavesi (1990) relata que massa específica do solo entre 1,2 e $1,4 \mathrm{~g} / \mathrm{cm}^{3}$ já pode constituir uma barreira para o crescimento radicular das plantas, sendo crítico na densidade de $1,6 \mathrm{~g} / \mathrm{cm}^{3}$. Kasper et al. (1978) observaram que o máximo grau de crescimento das raízes de soja, independente do manejo ou das propriedades físicas do solo, ocorreu durante o florescimento e diminuiu na fase inicial de enchimento dos grãos. Da mesma forma, a maior concentração de raízes ocorreu na superfície, entre 0 a $15 \mathrm{~cm}$ de profundidade (Kasper, 1985). Redução no desenvolvimento radicular da soja devido à compactação é mencionada por Benez et al. (1986), Pedo et al. (1986), Borges et al. (1988), Moraes et al. (1995) è Torres et al. (1995a).

Moraes et al. (1991) observaram reduções no desenvolvimento radicular da soja a partir de densidades do solo superiores a $1,26 \mathrm{~g} / \mathrm{cm}^{3}$ em Terra Roxa Estruturada e $1,17 \mathrm{~g} / \mathrm{cm}^{3}$ em Latossolo Roxo. As reduções da massa radicular foram superiores a $50 \%$ na Terra Roxa Estruturada, para massa específica do solo de $1,30 \mathrm{~g} / \mathrm{cm}^{3}$ e de cerca de $60 \%$ no Latossolo Roxo, com densidade de $1,23 \mathrm{~g} / \mathrm{cm}^{3}$. Em condições de laboratório, Borges et al. (1988) verificaram que a partir da densidade de $1,25 \mathrm{~g} / \mathrm{cm}^{3}$ em Latossolo Vermelho Escuro, não mais se observou crescimento de raízes de soja. Moraes et al. (1995) verificaram reduções na matéria seca de raízes de soja, em Latossolo Roxo, de $29 \%$ e $41 \%$, quando se elevou a massa específica do solo de 0,9 para 1,23 e 1,30 $\mathrm{g} / \mathrm{cm}^{3}$, respectivamente.

No sistema de plantio direto, o adensamento das camadas superficiais e subsuperficiais é, muitas vezes, compensado pela 
continuidade dos poros resultantes da atividade biológica e da decomposição das raízes (Gassen \& Gassen, 1996; Balbino, 1997). Neste sentido, Vieira (1981) observou que, após seis anos de plantio direto contínuo, as condições físicas do solo não ofereceram restrição ao crescimento radicular da soja. Em outro trabalho, Vieira (1985) menciona, inclusive, que o sistema radicular da soja é melhor distribuído no perfil do solo no sistema de plantio direto do que no manejo convencional com grade aradora ou arado de disco. Veigas \& Oliveira (1976) salientaram também que o sistema de plantio direto propicia um melhor desenvolvimento radicular da soja nas fases de crescimento vegetativo e florescimento e que, em condições de campo, os diversos modos de preparo do solo não influenciam a profundidade da raiz principal, nem o comportamento das raízes laterais. Entretanto, Cardoso (1993) mostrou que no cerrado, as raízes da soja se desenvolvem melhor em profundidade quando o solo é preparado com arado de aivecas, em relação ao arado de disco ou plantio direto.

Torres \& Saraiva (1997) observaram em plantio direto, que o desenvolvimento das raízes foi melhor quando o solo, Latossolo Roxo, foi previamente descompactado com escarificação, apresentando densidade de $1,20 \mathrm{~g} / \mathrm{cm}^{3}$. No solo compactado, com densidade de $1,35 \mathrm{~g} / \mathrm{cm}^{3}$, houve restrição ao crescimento radicular nos cinco cultivares testados. A compactação afetou negativamente a produtividade de todos os cultivares avaliados. Jaster et al. (1993) relataram que, no plantio direto, as raízes da soja se desenvolvem mais intensamente na camada superficial $(0-5 \mathrm{~cm})$, entretanto, na aração se verificou boa distribuição das raízes até a profundidade de $30 \mathrm{~cm}$. Superioridade no desenvolvimento radicular na cultura da soja em solo descompactado com escarificação profunda foi descrita por Maia \& Eltz (1992); Torres et al. (1995a); Torres \& Saraiva 
(1995a). As grades aradoras, por outro lado, resultam na pior distribuição radicular, sendo bastante superficial (Maia \& Eltz, 1992; Torres \& Saraiva, 1995a). Correlação positiva entre desenvolvimento radicular e rendimento de soja foram observados por Torres et al. (1995a); Torres \& Saraiva (1995a), Torres \& Saraiva (1997).

Para a cultura do feijão tem sido relatado que, em condic̣ões ideais de solo, as raízes podem atingir 1,5 $\mathrm{m}$ de profundidade (Robertson et al., 1978). Em termos práticos, no entanto, devido provavelmente ao tipo de solo e à presença de um ou mais tipos de impedimento de ordem física ou química, a literatura mostra que as raízes desta leguminosa se desenvolvem comumente até $50-60 \mathrm{~cm}$ de profundidade (Inforzato, 1963; Rovira, 1975; Oliveira \& Silva, 1990; Pires et al., 1991; Stone \& Pereira, 1994b). No caso do feijão irrigado por aspersão, a concentração das raízes na superfície parece ser ainda maior (Oliveira \& Silva, 1990; Pires et al., 1991; Teixeira et al., 1992; Stone \& Pereira, 1994b). Este fato é, provavelmente, devido ao manejo da irrigação apenas na camada superficial, 0-30 cm, tratando-se de irrigação por pivô central.

Rovira (1975) concluiu que a faixa de solo com dominância de absorção de nutrientes pelo feijoeiro é localizada entre 10 e $20 \mathrm{~cm}$ de profundidade. Estudos sobre a resistência à seca com esta cultura mostram que as raízes mais profundas do feijoeiro foram positivamente correlacionadas com a produção de grãos e crescimento das plantas (Sponchiado et al., 1989), e alguns genótipos, apesar de enraizarem mais intensamente na superfície do solo, podem ter o sistema radicular explorando até $100 \mathrm{~cm}$ de profundidade (Guimarães et al., 1996).

Stone \& Silveira (1996) mostraram que a compactação subsuperficial devida ao preparo do solo com grade, induz à concentração 
superficial das raízes do feijoeiro, até $10 \mathrm{~cm}$. Na aração com aivecas, observou-se boa distribuição de raízes até $40 \mathrm{~cm}$ de profundidade e no plantio direto, a maior parte das raízes concentrou-se nos primeiros $20 \mathrm{~cm}$ de profundidade.

De maneira similar às demais culturas, mais de $70 \%$ das raízes do arroz de terras altas concentram-se nos primeiros $20 \mathrm{~cm}$ de profundidade (Stone \& Pereira, 1994a; Stone \& Moreira, 1998). Guimarães \& Moreira (1997) concluíram que, na profundidade até $40 \mathrm{~cm}$, a densidade radicular do arroz diminui com o aumento da compactação a partir da massa específica do solo em torno de $1,2 \mathrm{~g} / \mathrm{cm}^{3}$. Guimarães (1997) concluiu que, comparativamente ao plantio direto, a aração promoveu maior desenvolvimento das raízes em profundidade. No sistema de plantio direto, observou-se, também, redução no desenvolvimento da parte aérea do arroz.

Stone \& Moreira (1998) observaram melhor distribuição das raízes do arroz no preparo do solo realizado com arado de aivecas em relação à grade aradora, e similar ao plantio direto. Grohmann \& Queiroz Neto (1966) observaram que houve impedimento físico ao desenvolvimento das raízes do arroz quando a massa especifica aparente do solo atingiu valores superiores a $1,42 \mathrm{~g} / \mathrm{cm}^{3}$ no Latossolo Roxo e 1,38 no Podzólico Vermelho Amarelo. Bouzinac et al. (1987) relataram que no solo preparado com grade aradora, $85 \%$ das raízes do arroz se concentraram nos primeiros $10 \mathrm{~cm}$. Com a aração invertida (grade aradora seguido da aração), além do acréscimo no volume total de raízes, $49 \%$ delas ficaram distribuídas no perfil $10-60 \mathrm{~cm}$ de profundidade.

Na cultura do milho, a maior concentração de raízes ocorre nos $20 \mathrm{~cm}$ superficiais (Mengel \& Barber, 1974; Durieux et al., 1994), e a profundidade efetiva de exploração depende do tipo de solo (Resende et al., 
1990). Anderson (1987) concluiu que o desenvolvimento mais intenso das raízes do milho ocorre até a $8^{a}$ semana após o plantio. Jansen \& Weert (1977); Pedo et al. (1986) e Hughes et al. (1992) observaram que em solo compactado ocorre restrição ao desenvolvimento radicular do milho, quase sempre refletindo na produção de grãos.

Gill et al. (1996) relataram que as raízes do milho se desenvolvem melhor em solo descompactado com escarificação em relação a grade aradora. Comparando o preparo convencional com arado de disco, escarificação e plantio direto, Newell \& Wilhelm (1987) verificaram maior concentração de raízes do milho no sistema de plantio direto e escarificação no perfil 0-15 cm. Melhor distribuição radicular do milho em profundidade devido à subsolagem também foi verificada por Manfron et al. (1991).

Correlação positiva entre melhor desenvolvimento radicular e rendimento de grãos de milho foi registrada por Choudhury et al. (1991) e Gill et al. (1996).

\subsection{Manejo do solo e rendimento das culturas}

O rendimento de grãos na maioria das culturas sob diferentes manejos do solo depende, dentre outros, das condições climáticas do ano agrícola, da qualidade do manejo, do nível de fertilidade do solo e do estado sanitário da cultura. Por estas razões, tem sido bastante variável na literatura, o comportamento das culturas sob diferentes manejos do solo. É preciso destacar, contudo, que nos anos em que ocorre deficiência hídrica, perdas de rendimentos quase sempre são registradas. A soja, por exemplo, que pode ser tomada como referência por suportar pequenas variações na 
distribuição das chuvas, teve redução no rendimento na região Sul do Brasil, nas safras $1977 / 78$ e 1978/79, da ordem de $32 \%$ ao ano, devido à ocorrência de veranicos. Deixou-se de colher 7,2 milhões de tonelada de grãos, equivalente a US\$1,3 bilhão (Farias et al., 1993). É razoável concluir que neste período, sistemas alternativos de manejo do solo, como a escarificação e a aração profunda e também o plantio direto, eram ainda muito pouco empregados na exploração da cultura de soja.

Espinosa (1983) avaliando 12 genótipos de soja, concluiu que, com enraizamento superficial, onde $70 \%$ a $80 \%$ das raízes encontravam-se no perfil $0-20 \mathrm{~cm}$ de profundidade, ocorreu redução média no rendimento de grãos da ordem de 50\%, quando os genótipos foram submetidos a um período de deficiência hídrica superior a 30 dias. Segundo Carmo (1997), no cerrado, as perdas de rendimentos causadas pela deficiência hídrica correspondem, em média, a uma safra a cada 5 anos. Nesta região ocorrem perdas anuais de $26 \%, 17 \%, 23 \%$ e $38 \%$ nos rendimentos de soja, milho, feijão e arroz, respectivamente, uma vez comparados aos rendimentos destas culturas com irrigação suplementar. Estas reduções podem ser reflexos da compactação, da baixa capacidade de armazenamento de água no solo devido aos baixos teores de matéria orgânica, da correção inadequada do perfil do solo ou ainda do fraco enraizamento das culturas. É possivel então considerar que o efeito da compactação e do enraizamento superficial sobre o rendimento de grãos é bastante dependente da pluviosidade do ano agrícola.

De acordo com a literatura, a soja é, dentre as principais culturas, uma das que melhor se adaptam ao sistema de plantio direto e, de um modo geral, os resultados de literatura indicam que os rendimentos desta cultura, considerando o efeito médio de várias safras, geralmente se 
eqüivalem nos diferentes sistemas de manejo do solo, com pequena vantagem para o plantio direto (Muzilli, 1981a; Landers, 1995a).

Superioridade do plantio direto no rendimento de grãos de soja é mencionada por Ramos \& Dedecek (1979), Sidiras et al. (1983) e Torres \& Saraiva (1995b), e em regiões de clima tropical e subtropical. Resultados semelhantes para os diversos manejos, envolvendo plantio direto e um ou mais sistemas de revolvimento/descompactação do solo, foram obtidos por Guedes et al. (1978), Oliveira et al. (1988a,b), Oliveira et al. (1989), Balbino \& Oliveira (1992) e Kochhann \& Denardin (1997).

$\mathrm{Na}$ maioria dos estudos onde foram utilizados o preparo com escarificador e grade aradora, ficou evidente que a escarificação quase sempre ocupou lugar intermediário no rendimento da soja e a grade, via de regra, resultou nos mais baixos rendimentos (Torres et al., 1988; Oliveira et al., 1989, Balbino \& Oliveira et al., 1992; Seguy et al., 1992a,b; Torres \& Saraiva, 1995a,b). Alguns autores também relatam a superioridade do arado de aiveca e de discos no rendimento da soja em relação ao plantio direto, quase sempre referindo-se ao efeito nocivo da compactação do solo (Oliveira et al., 1988a,b; Oliveira et al., 1989; Oliveira \& Silva, 1990; Lattanzi, 1992; Balbino \& Oliveira, 1992).

De maneira similar à soja, os resultados obtidos com a cultura do milho nos diferentes manejos do solo são bastante diferenciados. Steinhardt (1983) destacou a importância da descompactação do solo para esta cultura. Em anos mais secos, o efeito da compactação reduziu o rendimento de grãos em até $50 \%$ e, na média de cinco anos, este decréscimo devido ao mesmo fator, foi de cerca de $25 \%$.

Maiores rendimentos de milho no sistema de plantio direto, em relação a um ou mais sistemas de revolvimento do solo, foram relatados por 
Ismail et al. (1994); Machado (199_) e Hernani (1997), enquanto que resultados que mostraram semelhança entre os sistemas de manejo do solo foram descritos por Bayer et al. (1988), Oliveira et al. (1988b), Seguy et al. (1993), Torres et al. (1995b), Uhde et al. (1996) e Kochhann \& Denardin (1997), e inferioridade do plantio direto em relação a maioria dos demais sistemas, por Fancelli \& Favarin (1989b), Oliveira et al. (1989) e Balbino et al. (1994). Alguns estudos mostraram que o uso das grades aradoras tem resultado nos piores rendimentos de grãos (Seguy et al. 1993; Balbino et al. 1994). A escarificação tem demonstrado superioridade em relação aos demais sistemas, de acordo com estudos conduzidos por Edwards et al. (1988), ou resultado intermediário entre os sistemas, conforme Oliveira et al. (1989).

Poucas pesquisas envolvendo variados manejos do solo foram realizadas com a cultura do feijão. Em regime de sequeiro, Mullins et al. (1988), concluíram que não há diferença no rendimento desta cultura entre os sistemas convencional e de plantio direto. Landers (1995a) mencionou que, em nível de produtor, na região de Barreiras - BA, maiores produtividades tendem a ser obtidas no plantio direto em relação ao sistema convencional. Siqueira et al. (1993) mencionaram que o revolvimento do solo através da aração, independente da cobertura vegetal, sempre proporcionou melhores rendimentos ao feijoeiro.

Em outros estudos, Merten (1994) e Silva et al. (1996) destacaram ligeira superioridade do plantio direto no rendimento de grãos do feijoeiro em relação aos manejos com grade, aração, ou escarificação. No Brasil Central, Stone \& Silveira (1996); Silveira \& Silva (1996) e Urchei (1996) verificaram maiores rendimentos do feijoeiro irrigado por aspersão no sistema de plantio direto. Stone \& Silveira (1996) e Silva et al. (1996) 
concluíram que os menores rendimentos do feijoeiro foram obtidos no manejo do solo com grade aradora, enquanto Silveira et al. (1994) não verificaram diferenças entre aração superficial e profunda.

O arroz de terras altas parece ser, dentre a maioria das principais culturas, o menos adaptado ao sistema de plantio direto, embora as razões desta observação ainda careçam de informações mais precisas. Segundo Seguy et al. (1989), o arroz é, dentre todos os cultivos, o mais sensivel à qualidade do perfil do solo, quaisquer que sejam as condições climáticas. Isto, provavelmente, indica maior sensibilidade desta cultura à compactação/adensamento do solo, com conseqüente redução de macroporosidade. Neste sentido, Stone \& Moreira (1996) concluíram que na ausência de compactação, o preparo superficial do solo resultou no melhor. rendimento de grãos. Em solos com presença de compactação, Seguy \& Bouzinac (1992) obtiveram os menores rendimentos no sistema de plantio direto, rendimentos intermediários para o preparo com grade aradora e os melhores com aração profunda. Menores rendimentos do arroz no plantio direto foram também encontrados por Stone et al. (1980). Para esta cultura, estes autores recomendaram a aração ou a escarificação profunda como mais apropriadas. 


\section{MATERIAL E MÉTODOS}

\subsection{Caracterização da região e da área experimental}

O estudo foi conduzido na fazenda Três Irmãos, no município de Santa Helena, região Sudoeste do Estado de Goiás, a 17048'49" de

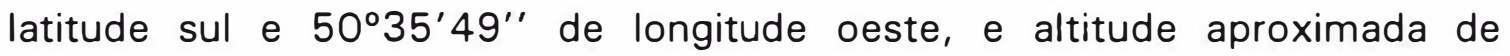
$615 \mathrm{~m}$.

O período chuvoso nesta microrregião, assim como nas demais subregiões do cerrado, concentra-se entre setembro/outubro até abril/maio, com precipitação média anual em torno de 1643 mm (Assad, 1995). Deste total, cerca de $1401 \mathrm{~mm}$ ocorrem entre outubro e março.

A propriedade escolhida vem sendo explorada com agricultura durante as quatro últimas décadas, sendo as duas últimas em sistema intensivo, com irrigação por aspersão. A exploração agrícola, baseada em alta tecnologia, destina-se, basicamente, à produção de sementes de feijão, sorgo e milho. A soja é utilizada como componente na rotação de culturas. No período seco e mais frio do ano, que vai de maio a setembro, a pecuária também é explorada na forma de confinamento, quando parte da alimentação animal é derivada de resíduos da agricultura. A partir de 1988 
iniciou-se a implantação do sistema de plantio direto, sendo hoje toda a propriedade, cerca de 700 ha, explorada com este sistema.

A gleba 3-A, onde o presente estudo foi conduzido, vem sendo explorada no sistema de plantio direto desde 1988. Na tabela 3 constam as culturas que compuseram a sucessão/rotação de culturas a partir de 1991. A irrigação nesta gleba é feita pelo sistema de autopropelido.

Tabela 3. Seqüência de culturas na gleba 3-A no período 1991/96, na fazenda Três Irmãos. Santa Helena, GO.

\begin{tabular}{llll}
\hline Ano Agrícola & \multicolumn{3}{c}{ Safra } \\
\cline { 2 - 4 } & Verão & Outono & Inverno (irrigado) \\
\hline $1990 / 91$ & Soja & Milho & Feijão \\
$1991 / 92$ & Soja & Sorgo granifero & Feijão \\
$1992 / 93$ & Milho & Crotalaria & Feijão \\
$1993 / 94$ & Milho & - & Feijão \\
$1994 / 95$ & Milho & Sorgo forrageiro & Feijão \\
$1995 / 96$ & Soja & Milho & Sorgo granifero \\
$1996 / 97$ & Experimentos & Sorgo forrageiro & Experimento \\
& (soja, milho, arroz) & & (feijāo)
\end{tabular}

\subsection{Caracterização do solo}

O solo de gleba 3-A é classificado como Latossolo Roxo eutrófico, com textura franco-argilo arenosa no perfil $0-20 \mathrm{~cm}$ e argiloso de 20 a $40 \mathrm{~cm}$ de profundidade. A análise textural mostrou, no perfil $0-20 \mathrm{~cm}$ 
de profundidade, $330 \mathrm{~g} / \mathrm{kg}$ de argila, $250 \mathrm{~g} / \mathrm{kg}$ de silte e $420 \mathrm{~g} / \mathrm{kg}$ de areia. No perfil 20-40 cm foram encontrados $470 \mathrm{~g} / \mathrm{kg}$ de argila, $190 \mathrm{~g} / \mathrm{kg}$ de silte e $340 \mathrm{~g} / \mathrm{kg}$ de areia.

As características químicas mostram tratar-se de solo com alta fertilidade, com homogeneidade de $\mathrm{pH}$ no perfil e relativa concentração de alguns nutrientes na superfície, decorrente das sucessivas adubações superficiais (Tabela 4).

A análise física revelou a presença de uma camada subsuperficial com relativo adensamento/compactação, entre 5 e $20 \mathrm{~cm}$ de profundidade, com conseqüente redução da macroporosidade (Tabela 5), revelando também boa distribuição de agregados (Tabela 6), principalmente na superfície, decorrente do alto teor de matéria orgânica.

A cobertura do solo com resíduos vegetais, por ocasião da implantação dos experimentos de soja, milho e arroz de terras altas, foi de aproximadamente $60 \%$, com cerca de 3,7 t/ha de matéria seca resultante de restos culturais e plantas daninhas. Para o experimento de feijão, conduzido em sucessão ao arroz, a cobertura do solo foi superior a $90 \%$, registrando-se a presença de 6,7 t/ha de matéria seca. A presença de pouca cobertura nos cultivos de verão decorreu da ceifa do sorgo forrageiro, cultura anterior, bem como do manejo utilizado na fazenda, onde não são cultivadas espécies específicas para formação de cobertura, sendo esta baseada nos restos culturais e plantas daninhas. 


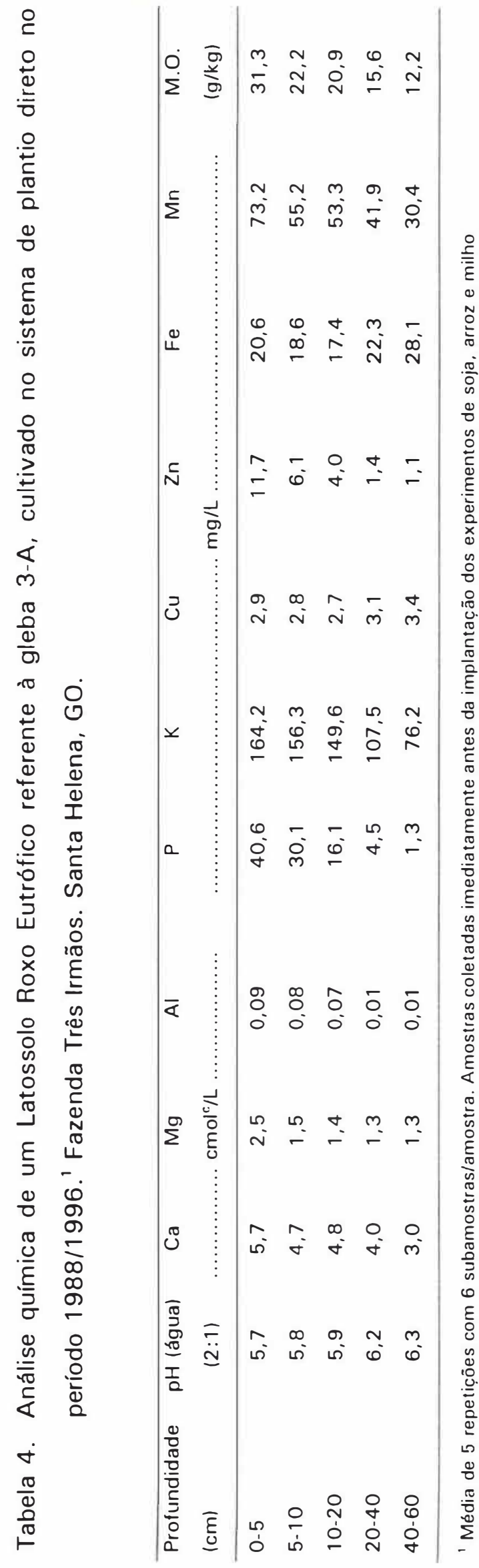


Tabela 5. Porosidade e densidade no perfil do solo referente à gleba 3-A, mantido sob plantio direto no período 1988-96. Fazenda Três Irmãos. Santa Helena, GO.'

\begin{tabular}{|c|c|c|c|c|}
\hline Tratamentos & $\begin{array}{c}\text { Microporosidade } \\
(\%)\end{array}$ & $\begin{array}{c}\text { Macroporosidade } \\
(\%) \\
\end{array}$ & $\begin{array}{c}\text { Porosidade Total } \\
\qquad \%)\end{array}$ & $\begin{array}{c}\text { Massa especifica } \\
\text { do solo } \\
\left(\mathrm{g} / \mathrm{cm}^{3}\right)\end{array}$ \\
\hline \multicolumn{5}{|c|}{ Experimento/Cultura } \\
\hline Arroz & $44,1 \mathrm{a}$ & $10,1 \mathrm{a}$ & 54,3 a & $1,17 \mathrm{~b}$ \\
\hline Soja & 47,0 a & 9,5 a & 54,5 a & $1,23 \mathrm{ab}$ \\
\hline Milho & 47,9 a & 9,2 a & $57,1 \mathrm{a}$ & $1,23 \mathrm{a}$ \\
\hline DMS & 5,10 & 3,00 & 4,16 & 0,05 \\
\hline CV $(\%)$ & 16,0 & 45,42 & 10,94 & 6,61 \\
\hline \multicolumn{5}{|c|}{ Profundidade $(\mathrm{cm})$} \\
\hline $0-5$ & $46,8 \mathrm{a}$ & $9,3 \mathrm{~b}$ & $56,2 a b$ & $1,19 \mathrm{~b}$ \\
\hline 5-10 & 47,5 a & $7,2 \mathrm{~b}$ & $54,8 \mathrm{bc}$ & $1,27 \mathrm{a}$ \\
\hline $10-20$ & $47,7 \mathrm{a}$ & $6,7 \mathrm{~b}$ & 53,3 a & $1,27 \mathrm{a}$ \\
\hline $20-40$ & 46,2 a & $9,7 \mathrm{~b}$ & 54,9 bc & $1,19 \mathrm{~b}$ \\
\hline $40-60$ & $43,6 \mathrm{~b}$ & 15,1 a & 57,7 a & $1,13 \mathrm{c}$ \\
\hline DMS & 2,03 & 3,08 & 2,10 & 0,06 \\
\hline CV $(\%)$ & 8,34 & 35,56 & 5,29 & 6,87 \\
\hline
\end{tabular}

${ }^{1}$ Média de 4 repetições e 2 amostras por repetição. Amostras coletadas imediatamente antes da implantação dos experimentos de soja, arroz e milho.

Médias seguidas da mesma letra, nas colunas, não diferem ao nivel de $P=0,05$ pelo teste de Tukey.

Tabela 6. Distribuição percentual dos agregados, do diâmetro médio ponderado (DMP) e da densidade de partículas (DP) no perfil do solo, referente à gleba 3-A, mantido sob plantio direto no período 1988/1996. Fazenda Três Irmãos. Santa Helena, GO.'

\begin{tabular}{lcccccccc}
\hline $\begin{array}{l}\text { Profundidade } \\
(\mathrm{cm})\end{array}$ & $2 \mathrm{~mm}$ & $1 \mathrm{~mm}$ & $0,5 \mathrm{~mm}$ & $0,25 \mathrm{~mm}$ & $0,1 \mathrm{~mm}$ & $<0,1 \mathrm{~mm}$ & $\begin{array}{c}\text { DMP } \\
(\mathrm{mm})\end{array}$ & $\begin{array}{c}\text { DP } \\
\left(\mathrm{g} / \mathrm{cm}^{3}\right)\end{array}$ \\
\cline { 2 - 6 } $0-5$ & 56,6 & 10,9 & 13,7 & 10,0 & 4,3 & 4,3 & 3,1 & 2,6 \\
$5-10$ & 29,9 & 14,7 & 23,7 & 17,7 & 6,6 & 6,6 & 1,9 & 2,7 \\
$10-20$ & 39,0 & 16,6 & 21,3 & 13,9 & 5,0 & 4,1 & 2,4 & 2,6 \\
$20-40$ & 56,0 & 11,6 & 13,6 & 10,6 & 6,1 & 2,5 & 3,1 & 2,6 \\
$40-60$ & 66,1 & 7,8 & 9,9 & 6,6 & 6,7 & 2,8 & 3,5 & 2,7 \\
\hline
\end{tabular}

1 Média de quatro repetiçōes e três subamostras por repetiçāo. Amostras coletadas imediatamente antes da implantação dos experimentos de soja, arroz e milho. 


\subsection{Tratamentos experimentais}

Foram conduzidos quatro experimentos em faixas, no delineamento de blocos completos casualizados, com quatro repetições (Tabela 7) (Gomes, 1970).

Tabela 7. Causas da variância do experimento em faixas no delineamento de blocos completos casualizados.

\begin{tabular}{lc}
\hline Causas da Variação & $\mathrm{GL}$ \\
\hline Manejo do solo (M) & 3 \\
Blocos & 3 \\
Resíduo (a) & 9 \\
\hline Adubação (A) & 2 \\
Residuo (b) & 6 \\
\hline Interação (M x A) & 6 \\
Resíduo (c) & 18 \\
\hline Total & 47 \\
\hline
\end{tabular}

As culturas da soja, milho, arroz de terras altas e feijão foram submetidas, separadamente, a quatro manejos do solo: plantio direto (PD); escarificação profunda (EP); grade aradora (GA) e aração profunda (AP), e a três níveis de adubação, com variação conjunta de fósforo e potássio: adubação baseada na recomendação oficial para o Estado de Goiás (To); correspondente às quantidades de fósforo e potássio exportados pelas colheitas esperadas (Eg) e sem aplicação de fósforo e potássio (T). Todas as culturas, em todos os tratamentos, receberam adubação de micronutrientes e, exceto para a soja, adubação nitrogenada no plantio e em cobertura (Tabela 8). 
Tabela 8. Níveis de adubação utilizados para as culturas.

\begin{tabular}{|c|c|c|c|c|c|c|}
\hline \multicolumn{2}{|c|}{$\begin{array}{l}\text { Cultura' } \\
\text { (rendimento esperado) }^{6}\end{array}$} & $\begin{array}{c}\mathrm{N}^{2} \\
\text { (base) }\end{array}$ & $\begin{array}{c}\mathrm{N}^{3} \\
\text { (cobertura) }\end{array}$ & $\mathrm{P}_{2} \mathrm{O}_{5}{ }^{4}$ & $\mathrm{~K}_{2} \mathrm{O}^{5}$ & FTE BR-12 \\
\hline $\begin{array}{l}\text { Milho } \\
\text { (9 t/ha) }\end{array}$ & $\begin{array}{l}\text { T } \\
\text { To } \\
\text { Eg }\end{array}$ & $\begin{array}{l}30 \\
30 \\
30\end{array}$ & $\begin{array}{l}30+90 \\
30+90 \\
30+90\end{array}$ & $\begin{array}{r}0 \\
60 \\
83\end{array}$ & $\begin{array}{r}0 \\
40 \\
55\end{array}$ & $\begin{array}{l}30 \\
30 \\
30\end{array}$ \\
\hline $\begin{array}{l}\text { Arroz } \\
(4 \mathrm{t} / \mathrm{ha})\end{array}$ & $\begin{array}{l}\text { T } \\
\text { To } \\
\text { Eg }\end{array}$ & $\begin{array}{l}30 \\
30 \\
30\end{array}$ & $\begin{array}{l}30 \\
30 \\
30\end{array}$ & $\begin{array}{r}0 \\
30 \\
37\end{array}$ & $\begin{array}{r}0 \\
30 \\
48\end{array}$ & $\begin{array}{l}30 \\
30 \\
30\end{array}$ \\
\hline $\begin{array}{l}\text { Soja } \\
\text { (3t/ha) }\end{array}$ & $\begin{array}{l}\text { T } \\
\text { To } \\
\text { Eg }\end{array}$ & $\begin{array}{l}0 \\
0 \\
0\end{array}$ & $\begin{array}{l}0 \\
0 \\
0\end{array}$ & $\begin{array}{r}0 \\
60 \\
35\end{array}$ & $\begin{array}{r}0 \\
40 \\
65\end{array}$ & $\begin{array}{l}30 \\
30 \\
30\end{array}$ \\
\hline $\begin{array}{l}\text { Feijão } \\
(2,5 \text { t/ha })\end{array}$ & $\begin{array}{l}\text { T } \\
\text { To } \\
\text { Eg }\end{array}$ & $\begin{array}{l}30 \\
30 \\
30\end{array}$ & $\begin{array}{l}70 \\
70 \\
70\end{array}$ & $\begin{array}{r}0 \\
60 \\
23\end{array}$ & $\begin{array}{r}0 \\
30 \\
45\end{array}$ & $\begin{array}{l}30 \\
30 \\
30\end{array}$ \\
\hline \multicolumn{7}{|c|}{ 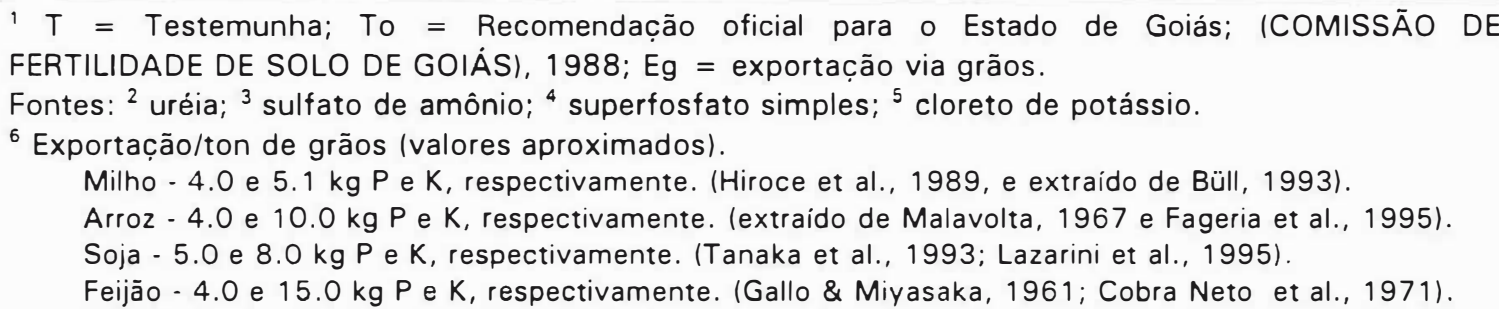 } \\
\hline
\end{tabular}

Para cada cultura instalou-se um experimento em faixas, com as quatro práticas de manejo do solo constituíndo o primeiro grupo de tratamentos (A) e os três níveis de adubação, o segundo grupo de tratamentos $(B)$.

Os experimentos com soja, milho e arroz foram conduzidos no período de verão do ano agrícola 1996/97, em regime de sequeiro e o de feijão em sucessão ao arroz, no período de inverno de 1997, com irrigação por aspersão, pelo sistema de autopropelido.

No período de inverno de 1997 foi conduzido, paralelamente ao experimento de feijão, estudo de alguns parâmetros microbiológicos do solo, em área adjacente, cujos tratamentos foram a aração profunda (AP) e o 
plantio direto (PD). Neste ensaio utilizou-se apenas a adubação nitrogenada em cobertura.

\subsection{Preparo do solo}

O preparo do solo para os diferentes manejos foi realizado com os seguintes implementos:

\subsubsection{Aração profunda com arado de aivecas (AP)}

Arado de duas conchas estriadas, revestidas em polietileno, marca Ikeda, modelo MR-2R, montado, com largura de corte de $40 \mathrm{~cm}$ por concha, tracionado com trator de $80 \mathrm{HP}$. A profundidade média de trabalho foi de $30 \mathrm{~cm}$. Antes da aração, os resíduos das faixas correspondentes aos tratamentos AP foram incorporados com grade aradora;

\subsubsection{Escarificação profunda (EP)}

Escarificador com quatro hastes helicoidais, marca Ikeda, modelo DP-4M, montado, com quatro discos de corte e rolo nivelador com nove lâminas fresadas, e largura de trabalho de $220 \mathrm{~cm}$. 0 implemento foi 
tracionado por trator de $118 \mathrm{HP}, 4 \times 4$, atingindo a profundidade média de 35 $\mathrm{cm} ; \mathrm{e}$

\subsubsection{Gradagem (GA)}

Grade aradora com 20 discos lisos com diâmetro de 66 cm, marca SuperTatu, modelo CR 1820. O implemento foi tracionado por trator de $80 \mathrm{HP}$ e a profundidade média de trabalho foi de $14 \mathrm{~cm}$.

Em nenhum tratamento efetuou-se a operação de nivelamento/ destorroamento mecânico do solo.

As datas referentes à execução desta e das demais atividades nos experimentos encontram-se inseridas na Tabela 9.

\subsection{Adubação e Semeadura}

Estas operações foram realizadas de forma mecânica e simultaneamente, utilizando-se semeadora marca Semeato, modelo PAR 2800, com oito linhas para soja e arroz, sete para feijão e quatro para milho. A plantadora era provida de discos de corte e o sistema de "botinhas" para sulcagem e distribuição de adubos e disco duplo, desencontrado para sulcagem e distribuição das sementes.

O mecanismo dosador de sementes da plantadora era em forma de disco perfurado horizontal, específico para cada tipo de semente. 
Tabela 9. Datas de realização das principais práticas culturais, amostragens e avaliações nos experimentos com as culturas da soja (S), Milho (M), Arroz (A) e Feijão (F). Fazenda Três Irmãos. Santa Helena. GO.

\begin{tabular}{|c|c|c|c|}
\hline Evento & Cultura & Data & Observaçāo \\
\hline Coleta de solo para análise física e química & $\mathrm{S}, \mathrm{M}, \mathrm{A}$ & $08 / 09 / 96$ & $\cdot$ \\
\hline \multirow[t]{2}{*}{ Preparo do solo } & $\mathrm{S}, \mathrm{M}, \mathrm{A}$ & $09 / 09 / 96$ & $\cdot$ \\
\hline & $F^{1}$ & $21 / 07 / 97$ & - \\
\hline \multirow[t]{3}{*}{ Dessecação das plantas daninhas } & $\mathrm{S}, \mathrm{A}$ & $30 / 09 / 96$ & Round up (2 I/ha) \\
\hline & $\mathrm{M}$ & $26 / 10 / 96$ & Round up (2 l/ha) \\
\hline & $\mathrm{F}$ & $12 / 06 / 97$ & Round up (2 I/ha) \\
\hline \multirow[t]{4}{*}{ Adubaçāo e semeadura } & $\mathrm{S}, \mathrm{A}$ & $08 / 10 / 96$ & - \\
\hline & $\mathrm{M}$ & $31 / 10 / 96$ & - \\
\hline & $\mathrm{F}$ & $17 / 06 / 97$ & $\cdot$ \\
\hline & $F^{\prime}$ & $26 / 07 / 97$ & 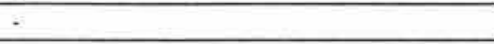 \\
\hline \multirow[t]{5}{*}{ Controle de plantas daninhas } & $\mathrm{S}$ & $30 / 10 / 96$ & $\begin{array}{l}\text { Flex }(0,5 \mathrm{l} / \mathrm{ha})+\text { Fuzilade }(0,7 \mathrm{l} / \mathrm{ha}) \\
(1 / 2 \text { dose })\end{array}$ \\
\hline & A & $\begin{array}{l}07 / 11 / 96 \mathrm{e} \\
31 / 11 / 96\end{array}$ & Manual \\
\hline & $M$ & $03 / 12 / 96$ & Sanson $(1,25 \mathrm{I} / \mathrm{ha})$ \\
\hline & & $26 / 12 / 96$ & Gramoxone (2 l/ha jato dirigido) \\
\hline & $\mathrm{F}$ & $02 / 07 / 97$ & Flex + Fuzilade (1/2 dose) \\
\hline \multirow[t]{3}{*}{ Contagem de população inicial } & $\mathrm{S}, \mathrm{A}$ & $17 / 10 / 96$ & - \\
\hline & $\mathrm{M}$ & $21 / 11 / 96$ & Realização do desbaste \\
\hline & $\mathrm{F}$ & $28 / 06 / 97$ & - \\
\hline \multirow[t]{4}{*}{ Cobertura nitrogenada } & A & $21 / 11 / 96$ & - \\
\hline & $\mathrm{M}$ & $21 / 11 / 96$ & $1^{\mathrm{a}}$ cobertura \\
\hline & & $17 / 12 / 96$ & $2^{a}$ cobertura \\
\hline & $\mathrm{F}$ & $08 / 07 / 97$ & \\
\hline \multirow[t]{4}{*}{ Amostragem de raiz e foliar } & $\mathrm{S}$ & $12 / 12 / 96$ & - \\
\hline & A & $14 / 01 / 97$ & - \\
\hline & M & $06 / 01 / 97$ & - \\
\hline & $\mathrm{F}$ & $13 / 08 / 97$ & - \\
\hline \multirow[t]{5}{*}{ Controle fitossanitário } & $\mathrm{S}$ & $14 / 12 / 96$ & Dissulfan (1,5 I/ha) percevejos \\
\hline & & $06 / 01 / 97$ & Dissulfan $(0,5 \mathrm{l} / \mathrm{ha})$ percevejos \\
\hline & A & $14 / 01 / 97$ & Azodrin $(0,5 \mathrm{l} / \mathrm{ha})$ Mocis latipes \\
\hline & $\mathrm{F}$ & $31 / 07 / 97$ & Azodrin $(0.5 \mathrm{l} / \mathrm{ha})$ lagarta das vagens \\
\hline & & $10 / 08 / 97$ & Tedion $80(2,0 \mathrm{l} / \mathrm{ha})$ ácaro rajado \\
\hline Área foliar & A & $30 / 01 / 97$ & 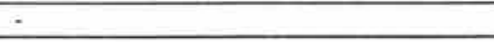 \\
\hline Altura das plantas & $\mathrm{S}, \mathrm{A}$ & $30 / 01 / 97$ & - \\
\hline Altura de inserçāo de espiga & $\mathrm{M}$ & $30 / 01 / 97$ & - \\
\hline Contagem de perfilhos & A & $30 / 01 / 97$ & - \\
\hline \multirow[t]{5}{*}{ Colheita e trilha } & A & $12 / 02 / 97$ & - \\
\hline & $\mathrm{S}$ & $13 / 02 / 97$ & - \\
\hline & $\mathrm{M}$ & $20 / 02 / 97$ & $\cdot$ \\
\hline & $\mathrm{F}$ & $08 / 09 / 97$ & - \\
\hline & $F^{1}$ & $23 / 10 / 97$ & - \\
\hline \multirow[t]{2}{*}{ Coleta de solo para análise física } & $A^{2}$ & $14 / 02 / 97$ & $\cdot$ \\
\hline & $F^{2}$ & $07 / 09 / 97$ & - \\
\hline \multirow[t]{3}{*}{ Coleta de solo para análise química ${ }^{2}$} & A, S & $14 / 02 / 97$ & + \\
\hline & $\mathrm{M}$ & $20 / 02 / 97$ & - \\
\hline & $\mathrm{F}$ & $09 / 09 / 97$ & $\cdot$ \\
\hline \multirow[t]{2}{*}{ Coleta de solo para análise microbiológica ${ }^{2}$} & $\mathrm{~F}$ & $09 / 09 / 97$ & $\cdot$ \\
\hline & $F^{\prime}$ & $23 / 10 / 97$ & - \\
\hline
\end{tabular}

\footnotetext{
'Ensaio paralelo para avaliação microbiológica do solo
}

${ }^{2}$ Após a colheita das culturas. 
As regulagens das adubações foram feitas pelo ajuste da alavanca reguladora e as da semente, pela mudança dos discos e alteração nas catracas motora e movida. Os sulcadores de adubo e semente foram regulados com pressão intermediária para possibilitar o enterrio em profundidade homogênea, nos diferentes manejos do solo.

\subsubsection{Soja cv. FT Estrela}

As sementes foram tratadas com $80 \mathrm{~g}$ de Rhodiauran e $200 \mathrm{~g}$ de inoculante para $40 \mathrm{~kg}$ de semente. O espaçamento utilizado foi de $45 \mathrm{~cm}$ entre linhas e densidade de $22-24$ sementes $/ \mathrm{m}$. A área da parcela foi de 36 $\mathrm{m}^{2}(7,2 \times 5,0 \mathrm{~m})$ ou 16 fileiras de $5 \mathrm{~m}$ e a área útil de $21.6 \mathrm{~m}^{2}$ ou 12 fileiras de $4 \mathrm{~m}$.

Este cultivar pertence ao grupo semitardio, ciclo de 123 dias, da emergência à maturação, susceptivel apenas à mancha café. É recomendado para o Estado de Goiás, na população de 300-350 mil plantas/ha.

\subsubsection{Milho híbrido BR 3123}

As sementes foram tratadas com 2,0 I de Fuzarin $/ 100 \mathrm{~kg}$ de sementes. Utilizou-se o espaçamento de $90 \mathrm{~cm}$ e densidade de 7-8 sementes/m. A área da parcela foi de $36 \mathrm{~m}^{2}(7,2 \times 5,0 \mathrm{~m})$ ou oito fileiras de $5 \mathrm{~m}$ e a útil de $18 \mathrm{~m}^{2}$ ou cinco fileiras de $4 \mathrm{~m}$. 
O cultivar é um híbrido triplo, ciclo de 63 dias para o florescimento, altura média de 2,20 m, ciclo até a maturação de 130 dias, altura média de inserção das espigas de $1,25 \mathrm{~m}$, grãos semi-duros e resistente ao acamamento. População recomendada de 55-62 mil plantas/ha.

\subsubsection{Arroz cv. Caiapó}

As sementes foram tratadas com 2,0 I de Furadan $/ 100 \mathrm{~kg}$ de sementes. Utilizou-se o espaçamento de $45 \mathrm{~cm}$ entre fileiras e densidade de 80-90 sementes $/ \mathrm{m}$. A área da parcela foi de $36 \mathrm{~m}^{2}(7,2 \times 5,0 \mathrm{~m})$ ou 16 fileiras de $5 \mathrm{~m}$ e a área útil de $21,6 \mathrm{~m}^{2}$ ou 12 fileiras de $4 \mathrm{~m}$.

O arroz Caiapó tem ciclo de 135-140 dias da emergência à colheita, moderada resistência à brusone nas panículas, altura média de 90 $\mathrm{cm}$, bom perfilhamento, porém susceptível ao acamamento.

\subsubsection{Feijão cv. Jalo Precoce}

As sementes foram tratadas com $200 \mathrm{~g}$ de Rhodiauran, $100 \mathrm{~g}$ de Benlate e 1,5 I de Furazin/100 kg de semente. O espaçamento utilizado foi de $45 \mathrm{~cm}$ entre fileiras e densidade de $12-14$ sementes $/ \mathrm{m}$. A área da parcela foi de $15.75 \mathrm{~m}^{2}(3,15 \times 5,0 \mathrm{~m})$ ou sete linhas de $5 \mathrm{~m}$ e a útil de 9,9 $\mathrm{m}^{2}$. 
Este cultivar é de ciclo precoce, floresce, em média, aos 27 dias após a emergência e a maturação de campo ocorre normalmente aos 72 dias após a emergência. Possui hábito de crescimento indeterminado (Tipo II), porte semi-ereto, grãos amarelos, pesando, em média, 35,5 g/100 sementes.

\subsubsection{Feijão cv. Pérola}

Este cultivar foi semeado na área destinada aos estudos microbiológicos do solo, no espaçamento de 0,45 m e na densidade de 12 14 sementes $/ \mathrm{m}$. Neste ensaio observou-se apenas o comportamento da atividade biológica do solo e o efeito do manejo sobre alguns fungos patogênicos do solo.

\subsection{Avaliação da população inicial de plantas}

A avaliação da população inicial de plantas de arroz e de soja foi realizada quatro dias após a plena emergência das plântulas, em oito subamostras de $1 \mathrm{~m} / \mathrm{manejo}$ do solo. Para o milho a avaliação foi efetuada 16 dias após a emergência, também em oito subamostras de $1 \mathrm{~m}$, realizando-se, simultaneamente, o desbaste do excedente a seis plantas $/ \mathrm{m}$. No caso do feijoeiro, a contagem foi realizada cinco dias após a emergência das plântulas. 
Durante as fases de desenvolvimento vegetativo e reprodutivo foram registrados todos os eventos fenológicos das culturas (Apêndices 1, $2,3$ e 4$)$.

\subsection{Amostragens}

\subsubsection{Análise química do solo}

As amostragens de solo para fins de análise de fertilidade foram coletadas com trado tipo rosca sem fim, nas profundidades de 0-5, 510, 10-20, 20-40 e 40-60 cm. As amostras destinadas à análise inicial foram compostas por seis subamostras. Após a colheita das culturas, repetiram-se as amostragens, sendo estas realizadas no tratamento testemunha para adubação (T) em todos os manejos, e foram compostas de três subamostras/parcela. Foram coletados cerca de $3 \mathrm{~kg}$ de solo por amostra.

\subsubsection{Análise física do solo}

As amostras destinadas a avaliação da densidade e porosidade foram coletadas em trincheiras, nas mesmas profundidades da análise química, utilizando-se anéis volumétricos, com capacidade para $98,17 \mathrm{~cm}^{3}$. Para determinação dos agregados, as amostras foram compostas de torrões. Para cada profundidade, na trincheira, efetuaram-se três amostragens. 


\subsubsection{Análise microbiológica do solo}

As amostras foram coletadas no perfil $0-10 \mathrm{~cm}$ de profundidade, exceto para avaliação do mofo branco, onde coletaram-se apenas $0.5 \mathrm{~cm}$ superficiais, nas parcelas testemunha para adubação $(T)$, após a colheita do experimento com soja. Cada amostra foi composta por três subamostras por parcela. $O$ mesmo procedimento foi utilizado no ensaio paralelo, após a colheita do feijão Pérola.

\subsubsection{Densidade radicular}

As amostragens foram realizadas no período de pleno florescimento das culturas, utilizando-se trado tipo haste, com $7,5 \mathrm{~cm}$ de diâmetro e $20 \mathrm{~cm}$ de comprimento. As amostras foram coletadas nas parcelas cuja adubação foi equivalente à exportação pela colheita (Eg), nas profundidades de 0-10, 10-20, 20-40, 40-60, 60-80 e 80-100 cm, sendo compostas de três subamostras por parcela. Cada subamostra correspondeu a $500 \mathrm{~cm}^{3}$ de solo, para cada dez centímetros de profundidade.

\subsubsection{Análise foliar}

As amostras foram coletadas na fase de pleno florescimento das plantas, em todos os tratamentos e repetições, sendo amostradas, para 
cada cultura, as duas folhas completamente desenvolvidas mais próximas do ápice das plantas. As amostras foram compostas de 40 trifólios para a soja e feijão, 10 folhas para o milho, e 80 para o arroz. As amostras foram imediatamente secas em estufa por cerca de 48 horas, a $72^{\circ} \mathrm{C}$, sendo posteriormente moídas e enviadas ao laboratório.

\subsection{Determinações analíticas}

\subsubsection{Análise química do solo}

Os nutrientes e $\mathrm{opH}$ (em água) foram determinados conforme metodologia, descritas no manual de métodos da EMBRAPA (1997a). O fósforo e o potássio foram extraídos pelo extrator Mehlich 1. O P foi determinado por colorimetria e o K por fotometria de chama. O cálcio, magnésio e alumínio foram extraídos em $\mathrm{KCl} 1 \mathrm{~N}$. O Ca e $\mathrm{Mg}$ foram determinados por titulação com EDTA $0.01 \mathrm{~N}$ e o Al com NaOH $0.01 \mathrm{~N}$.

O manganês, cobre, ferro e zinco foram determinados na mesma solução de $P$, por absorção atômica.

A matéria orgânica foi determinada pelo método proposto por Walkley \& Black (1934).

O boro foi extraído com água quente e determinado pelo método colorimétrico com azometina-H (Bataglia \& Raij, 1990). 


\subsubsection{Análise física do solo}

Os parâmetros físicos do solo foram também determinados segundo a metodologia proposta no manual de métodos da EMBRAPA (1997a).

A massa específica do solo foi determinada pelo método do anel volumétrico. As amostras foram secas em estufa por 24 a 48 horas e pesadas, e a densidade foi calculada pela razão entre a massa da amostra seca e o volume do anel.

A microporosidade foi determinada pelo método da mesa de tensão a $60 \mathrm{~cm}$ de altura, em amostras indeformadas, e correspondeu ao volume de água retido na tensão de $6 \mathrm{kPa}$.

A porosidade total foi calculada pelo índice de saturação (IS), o qual foi obtido pela expressão:

$$
I S=100\left(\frac{P S_{S}-P S}{P S}\right), \text { onde: }
$$

PSs é a massa da amostra saturada, e PS é a massa da amostra seca.

A porosidade total corresponde ao índice de saturação.

A macroporosidade foi determinada pela diferença entre a porosidade total e a microporosidade.

A estabilidade dos agregados em água foi determinada pelo método descrito pela EMBRAPA (1997a) modificado, onde uma amostra de $100 \mathrm{~g}$ de solo é utilizada para correção da umidade, determinando-se o fator de correção (FC). 


$$
F C=\frac{100+W}{100} \text {, onde: }
$$

W corresponde à correção de umidade. A massa da amostra (MS) foi calculada pela fórmula:

$$
\mathrm{MS}=\frac{100}{\mathrm{FC}} .
$$

A percentagem de agregados $(\mathrm{Ag})$ pela expressão:

$$
\mathrm{Ag}(\%)=\frac{400(\mathrm{PS} a-\text { Tara da Lata) }}{\mathrm{MS}}, \text { onde: }
$$

PSa = massa das amostras secas referente a cada peneira.

O diâmetro médio ponderado (DMP), foi calculado pela fórmula:

$$
D M P=D P \times \% A g, \text { onde: }
$$

DP corresponde ao diâmetro da peneira.

\subsubsection{Análise microbiológica do solo}

A metodologia utilizada para avaliação de alguns parâmetros microbiológicos no solo foi baseada em Tuite (1969).

O número de propágulos de microorganismos no solo foi determinado pelo método de diluição em série. 
Os meios de cultura seletivos Rosa de Bengala, AN lagar + nutriente), Nash \& Snyder, e agar simples foram utilizados para determinar, respectivamente, a população fúngica total, população bacteriana total, fungos das espécies Fusarium solani Esp. Phaseoli e Rhizoctonia solani. Para a determinação da atividade microbiológica total do solo utilizou-se método de dehidrogenase de fluoresceina diacetato descrito por Costa (1995). Para determinação da população de Sclerotinia scleorotiorum, as amostras coletadas, de $0-5 \mathrm{~cm}$, foram submetidas ao método de peneiramento descrito por Costa (1997a).

\subsubsection{Análise foliar}

Os nutrientes nas folhas, exceto o $\mathrm{B}$ e o $\mathrm{N}$, foram determinados pela metodologia descrita por Morais \& Rabelo (1986). As amostras foram digeridas em solução nitro-perclórica, e o P foi determinado por colorimetria e os demais, por absorção atômica.

Para o N, as amostras foram digeridas em ácido sulfúrico e mistura catalisadora e determinado por um digestor Tecator 1016/1004 unidades de destilação. O B foi determinado pelo método descrito por Correa et al. (1985). 


\subsubsection{Densidade radicular}

As amostras com solo e raízes foram dispersas em baldes com água. Pelo processo de suspensão/decantação repetitiva, separou-se todas as raízes da amostra de solo. Em seguida, as raízes foram recuperadas do sobrenadante em peneira de $0,25 \mathrm{~mm}$ e as impurezas, eliminadas com auxílio de pinça. Após este processo, as raízes foram avaliadas quantitativamente pelo método de Newman (1966), com o objetivo de determinar seu comprimento na amostra de solo. Dividiu-se o comprimento radicular, em $\mathrm{cm}$, pelo volume de três subamostras, em $\mathrm{cm}^{3}$, e encontrou-se a densidade linear radicular em $\mathrm{cm}$ lineares de raízes $/ \mathrm{cm}^{3}$ de de solo, conforme Proffitt et al. (1985) e Taylor (1986).

\subsection{Outras determinações}

A área foliar do arroz foi medida em três perfilhos por parcela, usando a metodologia do comprimento e largura (EMBRAPA/CNPAF, 1977). O número de panículas foi avaliado em $1 \mathrm{~m}$ por tratamento, na fase de maturação da cultura do arroz. A altura das plantas, também em amostras de $1 \mathrm{~m}$, foi medida desde a superfície do solo até a extremidade da panícula, no caso do arroz e até a inserção do legume mais próximo do ápice da planta, no caso da soja. A avaliação da produção de matéria seca corresponde a amostra de um metro de fileira de arroz de toda a parte aérea, excetuando os grãos, e toda parte aérea, excetuando as espigas, em dez plantas/parcela, no caso do milho. As amostras foram secas em estufa a $72^{\circ} \mathrm{C}$ durante cerca de 72 horas. 
A altura de inserção das espigas de milho foi avaliada em dez plantas/parcela. A incidência de Roselinea sp. na soja foi avaliada mediante a contagem, na parcela útil, de todas as plantas com sintomas. As avaliações referentes ao número, espécies e produção de matéria seca das plantas daninhas foram realizadas mediante a coleta de seis amostras de 1 $\mathrm{m}^{2}$ por manejo do solo, enquanto a cobertura morta do solo foi avaliada em oito repetições de $1 \mathrm{~m}^{2}$.

\subsection{Manejo da irrigação na cultura do feijão}

No dia anterior a implantação do experimento ocorreu a última chuva do ano agrícola 1996/97, totalizando $37,2 \mathrm{~mm}$. A partir da emergência do feijoeiro foram realizados 14 turnos de rega pelo sistema de aspersão por autopropelido. O turno médio de rega foi de cinco dias e, ao todo, foram aplicados cerca de $253 \mathrm{~mm}$ de água, correspondendo a uma lâmina bruta aproximada de $18 \mathrm{~mm}$ por turno de rega. A irrigação foi interrompida por ocasiāo da maturidade fisiológica da cultura.

\subsection{Colheita e avaliação dos componentes do rendimento}

As operações de ceifa ou arranquio, trilha e limpeza dos grãos foram realizadas manualmente para todas as culturas. A medição de umidade e a pesagem foram realizadas em seqüência e o peso final foi corrigido para $13 \%$ de umidade. 


\subsubsection{Soja}

A população final de plantas foi obtida mediante a contagem de todas as plantas da parcela útil. Os números de vagem por planta e sementes por vagem foram obtidos em amostras de dez plantas por parcela, coletadas aleatoriamente. A massa de 100 grãos foi determinada em três amostras por parcela, com umidade corrigida para $13 \%$.

\subsubsection{Milho}

A população final de plantas também foi obtida mediante a contagem de todas as plantas na parcela útil. Os números de fileiras por espiga e de grãos por fileira foram obtidos em amostras de dez espigas/parcela, e a massa de 100 grãos foi resultante de três amostras por parcela.

\subsubsection{Arroz de terras altas}

Os números de espiguetas cheias e vazias por panícula e o comprimento das panículas foram obtidos em amostras de dez panículas por parcela. A massa de 100 grãos foi determinada em três amostras por parcela. A esterilidade das espiguetas foi obtida mediante a transformação das estéreis em percentual do total. 


\subsubsection{Feijão}

A população final de plantas foi obtida pela contagem de todas as plantas na parcela útil. Os números de vagens cheias e vazias, e de sementes por vagem foram determinados em dez plantas por parcela, e a massa de 100 grãos em duas amostras por parcela.

\subsection{Procedimentos estatísticos}

As variáveis produção e seus componentes, altura das plantas, concentração foliar de nutrientes, altura de inserção de espigas de milho, incidência de Roselinea sp na soja, produção de matéria seca, área foliar e perfilhos foram avaliadas em todos os tratamentos e analisadas conforme $o$ esquema de experimento em faixas no delineamento de blocos completos casualizados.

As variáveis referentes aos parâmetros físicos e químicos do solo e desenvolvimento radicular das plantas foram avaliadas em apenas um nível de adubação e foram analisadas segundo o esquema experimental no delineamento de blocos ao acaso e parcelas subdivididas, considerando-se as diferentes profundidades como subparcelas.

As variáveis referentes a plantas daninhas, população inicial de plantas e avaliações microbiológicas do solo foram analisadas conforme o esquema experimental no delineamento de blocos ao acaso. 


\section{RESULTADOS E DISCUSSÃO}

\subsection{Condições climáticas durante o período de condução dos experimentos.}

Alguns atributos climáticos registrados durante o período de condução dos experimentos são apresentados na tabela 10 .

A distribuição de chuvas durante o período de outubro/96 e março/97, apresentou variação em relação à média dos anos anteriores. No mês de novembro ocorreu excesso de chuvas, podendo ter tido influência negativa no crescimento radicular das culturas de verão, bem como na incidência de radiação solar e por conseguinte na fixação de $\mathrm{CO}_{2}$ pelas plantas. Neste período, os eventos fenológicos das culturas registravam os seguintes estádios: soja- expansão do terceiro trifólio até a formação do primeiro legume; milho- emergência à expansão da $6^{\text {a }}$ folha; arroz- início do perfilhamento até o início do alongamento do colmo (Apêndices 1,2 e 3).

Outro destaque foi, também em relação à média de anos anteriores, a escassez de chuvas em fevereiro e março, tendo ocorrido neste intervalo, dois períodos de veranico em fevereiro e dois em março. Estes, porém, não afetaram as culturas, por estas estarem nos estádios finais do período reprodutivo. A temperatura e a umidade do ar parecem não ter causado qualquer distúrbio na cultura da soja. 


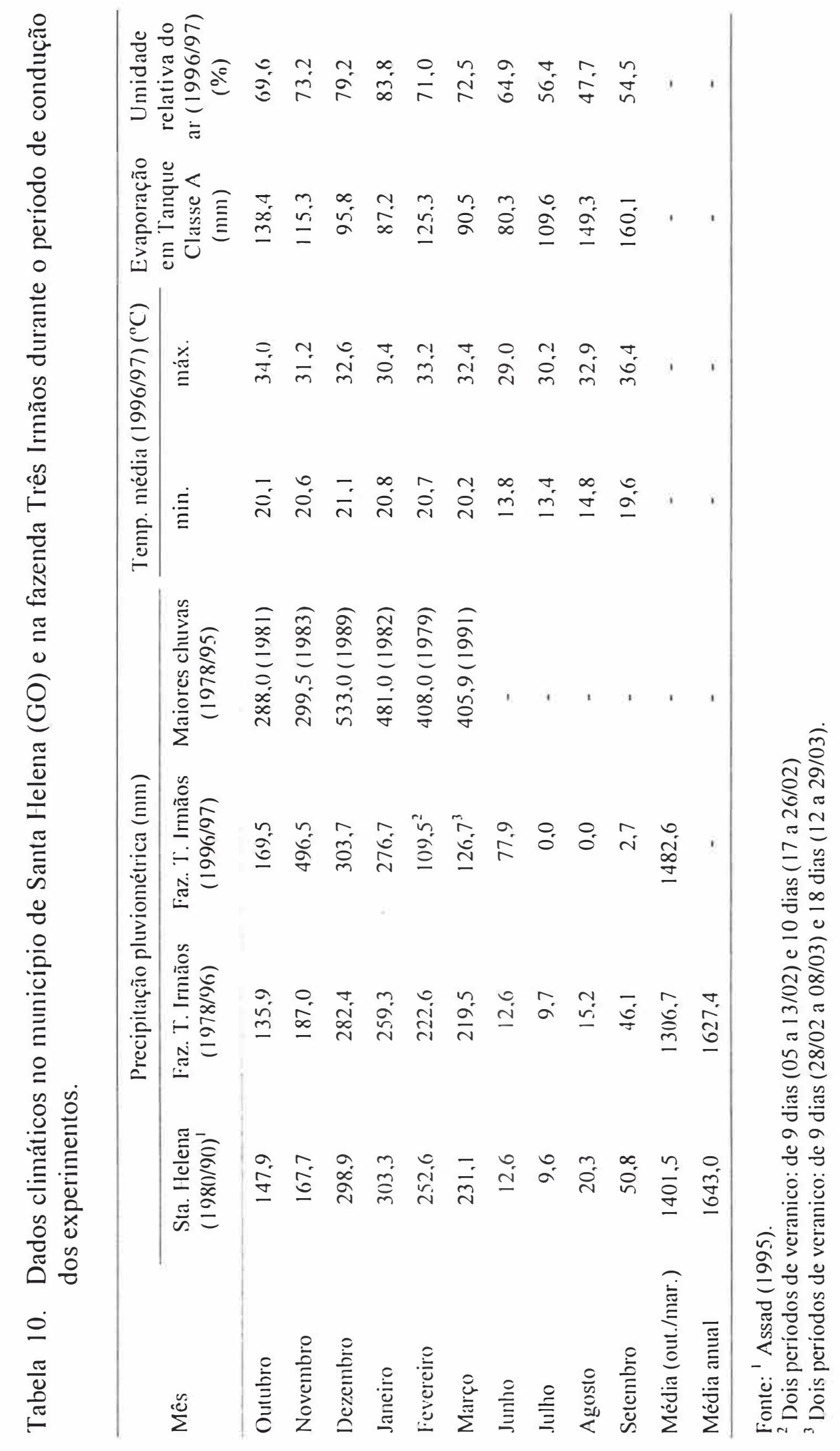


O efeito de altas temperaturas, principalmente durante o dia, no entanto, parece ter afetado negativamente as culturas do milho e do arroz, já que o ciclo do milho foi reduzido em cerca de 22 dias e o arroz apresentou rendimento muito abaixo do esperado. $O$ intenso ataque na cultura de milho de Phaeosphaeria maydis, doença fúngica foliar geralmente associada a altas precipitações e temperatura noturna mais amena, pode também ter interferido no ciclo e, conseqüentemente, no rendimento da cultura.

No período de inverno, a ausência total de chuvas nos meses de julho e agosto e temperatura mínima amena, podem ter favorecido a cultura do feijão sob irrigação, bem como resultado na menor incidência de doenças, principalmente foliares, o que realmente foi observado durante o desenvolvimento da cultura.

\subsection{Propriedades químicas e físicas do solo, após oito anos sob plantio direto}

A análise de solo revelou acidez média a moderada em todos os perfis estudados, cujo $\mathrm{pH}$ situou-se na faixa que possibilita a maior disponibilidade de nutriente para as plantas, de acordo com o comportamento dos nutrientes e a reação do solo discutida por Lopes (1989). Observou-se também ausência de alumínio em níveis tóxicos em todo o perfil e altos níveis de macro e micronutrientes, de acordo com a COMISSÃO DE FERTILIDADE DE SOLO DE GOIÁS (1988) e Cox (1987), e adequados para que as culturas, sob plantio direto, se desenvolvam sem 
problemas de fertilidade, de acordo com os níveis necessários e descritos por Balbino et al. (1996).

Em razão da Gleba 3-A ter sido cultivada no sistema de plantio direto durante o período 1988/96, com predominância de três cultivos por ano agrícola, com adubação de manutenção superficial e localizada, exceto para a soja, houve a concentração superficial de nutrientes, em especial o $P$, $\mathrm{K}, \mathrm{Mg}, \mathrm{Zn}, \mathrm{Mn}$ e $\mathrm{Cu}$, bem como da matéria orgânica (Tabela 4). Esta tendência é verificada em praticamente toda a literatura sobre o tema, destacando-se as pesquisas realizadas por Guedes et al. (1978), Muzilli (1983), Muzilli (1984), Sá (1993); Mullins (1995) e Franzluebbers \& Hons (1996).

$\mathrm{O} \mathrm{pH}$ mostrou-se ligeiramente inferior na superfície, zona de maior concentração de matéria orgânica e atividade biológica, sendo que igual tendência também foi observada por Dick (1983) e Franzluebbers \& Hons (1996) dentre outros. Entretanto, tendências contrárias foram observadas por Guedes et al. (1978) e Pauletti et al. (1995), possivelmente devido a origem do solo e/ou sucessivas calagens superficiais. A gleba 3-A não recebeu corretivos de acidez durante o período em que esteve sob plantio direto.

Em relação a algumas propriedades físicas, verificou-se a dominância de microporos em todo o perfil estudado e redução nos macroporos na superfície, em relação às camadas do solo abaixo de $20 \mathrm{~cm}$. A massa específica do solo revelou a presença de camada ligeiramente adensada/compactada na profundidade entre 5 e $20 \mathrm{~cm}$ (Tabela 5), estando de acordo com os estudos realizados por Vieira (1985), Torres \& Saraiva (1995a) e Ros et al. (1997). 
Os agregados do solo maiores que $2 \mathrm{~mm}$ foram mais representativos nos primeiros $5 \mathrm{~cm}$ de profundidade, em função do alto teor de matéria orgânica na superfície, tendo sido reduzidos sensivelmente no perfil 5-20 cm de profundidade. Os agregados de menor diâmetro apresentaram tendência inversa (Tabela 6).

\subsection{Cobertura do solo com resíduos vegetais}

A matéria seca de resíduos vegetais na superfície do solo por ocasião da implantação dos experimentos de soja, arroz e milho foi, em média, de 3,7 t/ha, permitindo a cobertura de aproximadamente $60 \%$ da superfície do terreno, coerente com as conclusões de Saraiva \& Torres (1993). Tanto o volume de palhada como o índice de cobertura do solo foram relativamente baixos, e segundo Gassen \& Gassen (1996), traz como conseqüência ineficiência na conservação de água, na redução da amplitude térmica do solo e na supressão de plantas daninhas, com reflexos negativos ainda sobre a atividade microbiológica e manutenção das propriedades físicas do solo. No caso particular da gleba 3-A, a não utilização de plantas específicas de cobertura e a ceifa do sorgo para fins de silagem que antecedeu a implantação dos experimentos, respondem por esta característica. Outro agravante é o clima na região, com predominância de altas temperaturas associadas a altas umidades do solo e ar durante a maior parte do ano, fazendo com que os resíduos vegetais sejam rapidamente consumidos pelos organismos do solo. De acordo com Seguy et al. (1992a), dependendo da origem dos resíduos, apenas entre 7 e 38\% 
permanecem na superfície do solo aos 90 dias após o início do período chuvoso, sendo a palhada de gramíneas a que apresenta maior longevidade.

A cobertura morta presente na área por ocasião da implantação do experimento com a cultura do feijão, foi em média de $7,6 \mathrm{t} / \mathrm{ha}$, protegendo praticamente toda a superfície do solo. Este nível deve-se a resíduos com maior relação $C / N$, resultantes da palhada de arroz colhido cerca de quatro meses antes.

Mesmo com a freqüente utilização de herbicidas de manejo e pós-emergentes na exploração agrícola da propriedade observou-se, nas condições da área experimental, abundância de plantas daninhas, tanto em população como em espécies, sendo as mais comuns, no sistema de plantio direto, o campim-colchão (Digitaria horizontalis), erva-de-santa-luzia (Euphorbia brasiliensis), caruru (Amaranthus hibridus) e a trapoeraba (Commelina benghalensis) (Figura 2 e Apêndice 5). O revolvimento do solo, principalmente com arado de aivecas foi eficiente para a redução, pelo menos temporária, da maior parte das espécies, estando de acordo com resultados obtidos por Seguy et al. (1984).

É importante salientar que esta relação deve-se principalmente a localização superficial do banco de sementes no solo, em função do período que a área vem sendo mantida sob plantio direto. Dados contidos na Tabela 11 mostram a importância das plantas daninhas como fonte de cobertura morta, as quais em cerca de um mês, após o preparo do solo ou o início das chuvas, produziram até cerca de 2,4 t/ha de matéria seca, sendo este resultado reflexo, tanto da alta fertilidade do solo, como da abundância de sementes no solo. 


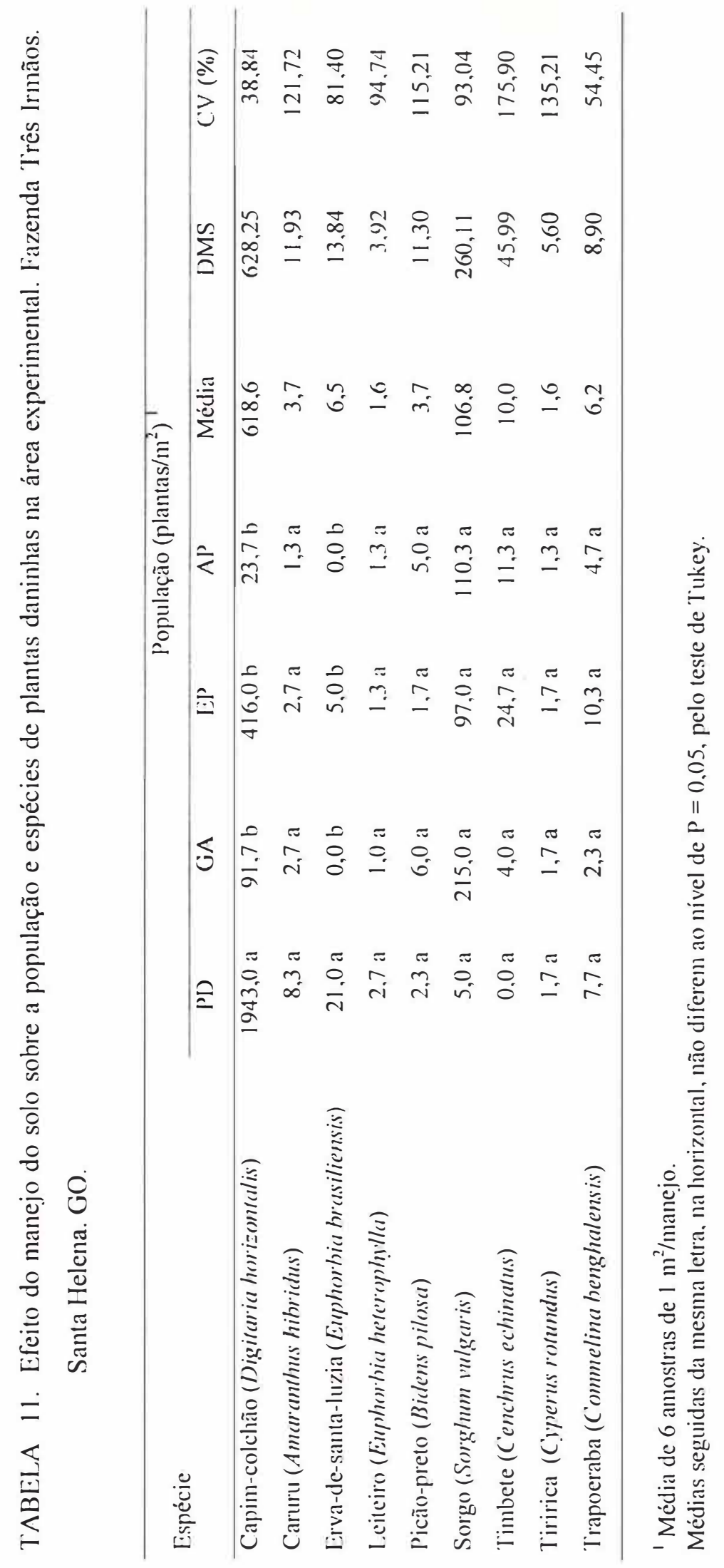




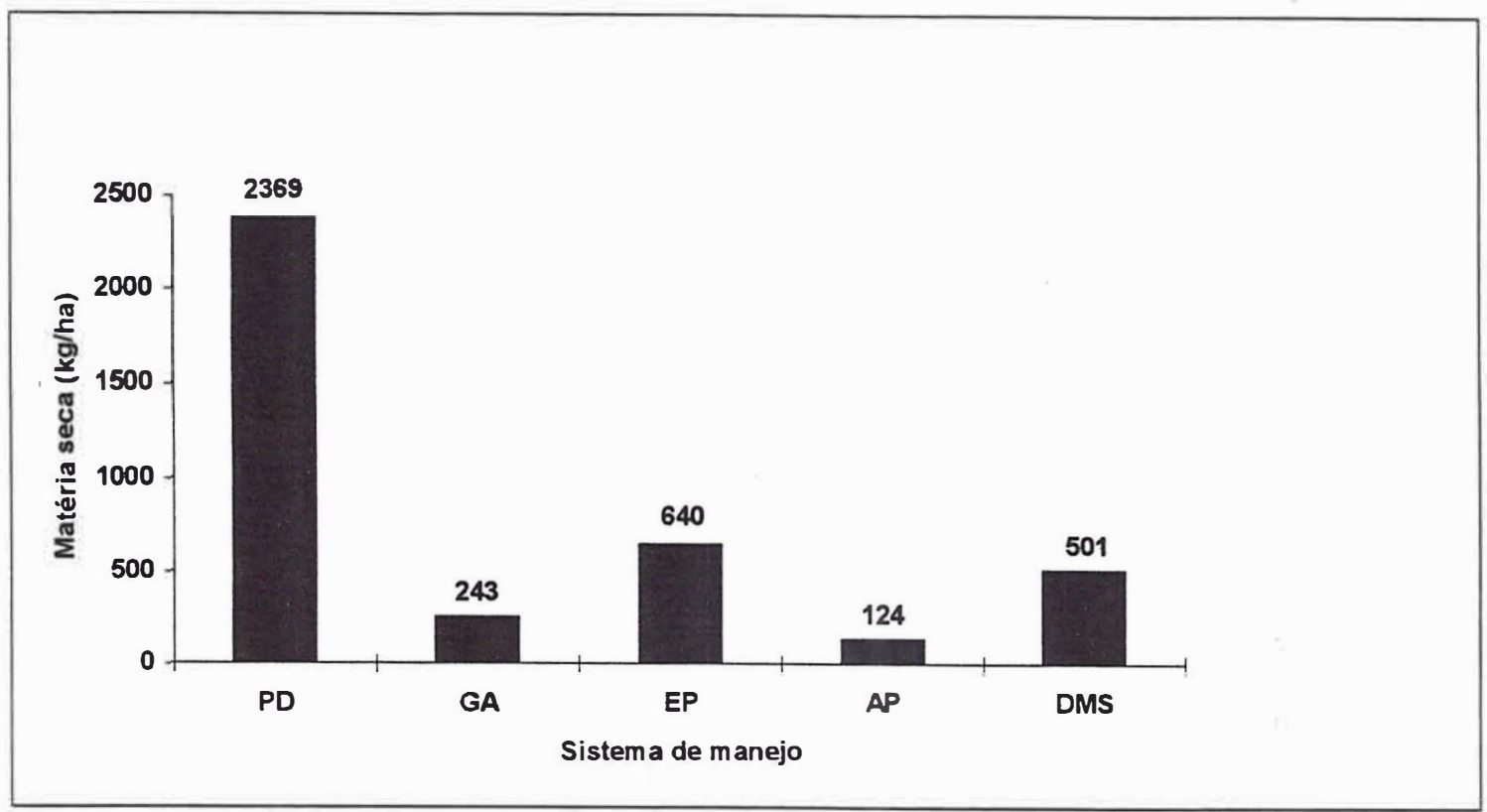

Figura 2. Efeito do manejo do solo sobre a produção da matéria seca das plantas daninhas, cerca de 1 mês após o início das chuvas e do preparo do solo, na gleba 3-A. Fazenda Três Irmãos. Santa Helena. GO.

\subsection{Comportamento da fertilidade do solo nos diferentes manejos após a colheita das culturas}

Os resultados referentes ao comportamento dos nutrientes no perfil do solo foram obtidos após a colheita das culturas.

Nos sistemas de manejo mantidos sob plantio direto e no preparo com escarificação registrou-se a mesma tendência observada antes da implantação dos experimentos. O P, Mg, Zn e Mn e a matéria orgânica mantiveram-se acumulados superficialmente, principalmente no perfil 0-10 $\mathrm{cm}$ de profundidade, enquanto $\circ \mathrm{K}$ e $\circ \mathrm{Ca}$ acumularam-se até $20 \mathrm{~cm}$ de profundidade (Figura 3), tendências também verificadas por Muzilli (1983) e Sá (1993). O revolvimento do solo com arado de aivecas resultou numa 

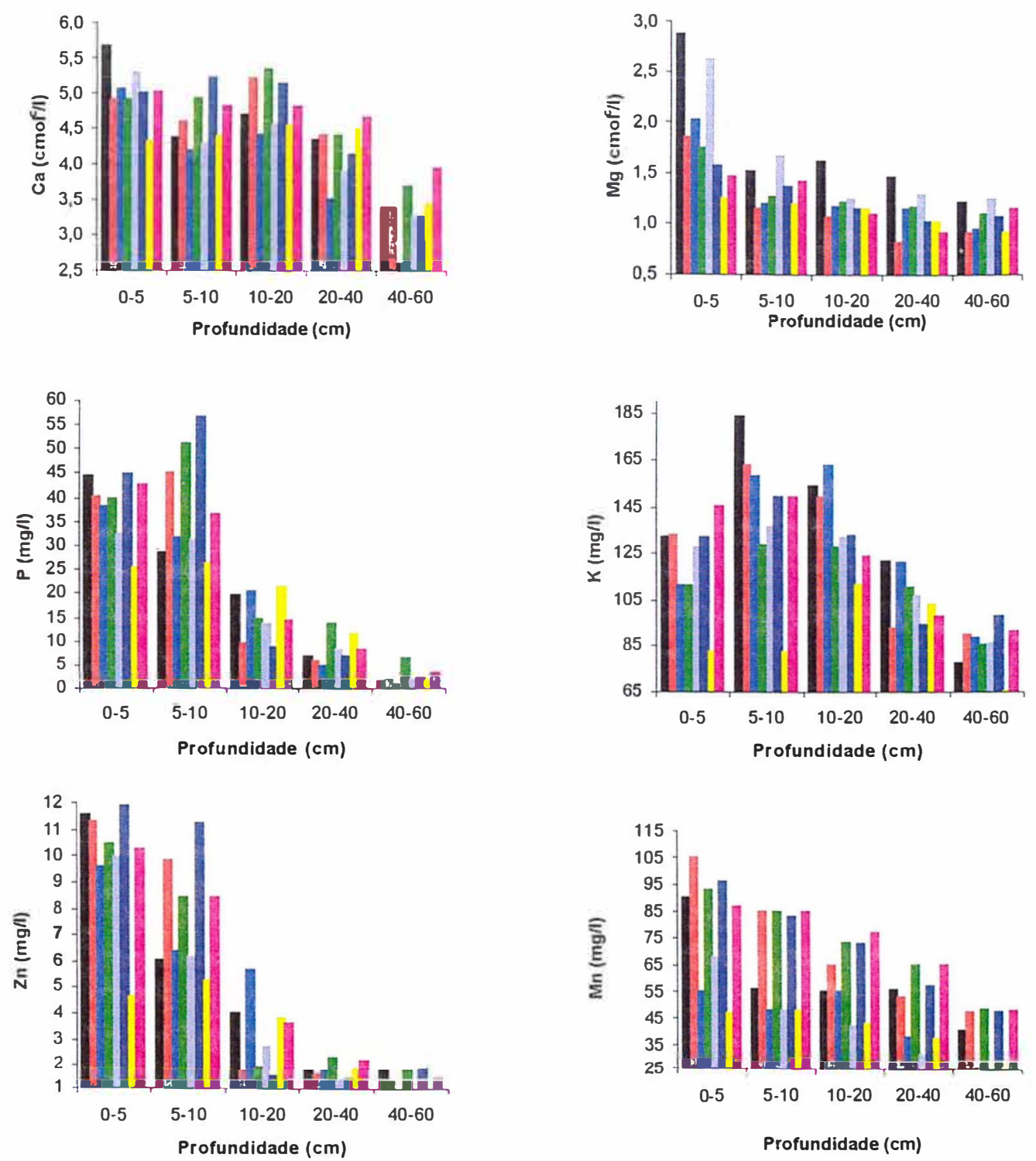

- $\mathrm{PD} 14 / 02 / 97$

GA 14/02/97

EP $14 / 02 / 97$ AP $14 / 02 / 97$

PD $09 / 09 / 97$

GA 09/09/97

EP 09/09/97

AP $09 / 09 / 97$

Figura 3. Efeito dos sistemas de plantio direto (PD), grade aradora (GA), escarificação (EP) e aração (AP) sobre a distribuição do $P, K, C a$, $\mathrm{Mg}, \mathrm{Zn}$ e Mn no perfil do solo após a colheita do arroz (14/02/97) e feijão em sucessão (09/09/97). 
melhor distribuição destes nutrientes no perfil do solo, pelo menos até 20 $\mathrm{cm}$ de profundidade para o $\mathrm{P}, \mathrm{Ca}, \mathrm{Mg}$ e $\mathrm{Zn}$ e até $40 \mathrm{~cm}$ para o $\mathrm{K}$ (Figura 3). Tratando-se de solo eutrófico, a acidez observada no perfil foi de média a moderada, inclusive com ligeiro acréscimo do $\mathrm{pH}$ em profundidade. A distribuição de Fe e Cu no perfil $0-60 \mathrm{~cm}$ foi homogênea, independente do manejo aplicado. Tendências semelhantes foram registradas por Muzilli (1984) e Kochhann \& Denardin (1997).

Após a colheita do milho (Tabela 12), em média para a profundidade, não houve efeito significativo do manejo do solo sobre os teores de $\mathrm{Ca}, \mathrm{Mg}, \mathrm{Al}, \mathrm{P}, \mathrm{K}, \mathrm{Zn}, \mathrm{Fe}$ e $\mathrm{Mn}$, bem como sobre o $\mathrm{pH}$. O maior teor de $\mathrm{Cu}$ no preparo com escarificação foi devido, provavelmente, à variabilidade espacial. A aração com aivecas elevou o teor médio de matéria orgânica, presumivelmente devido à intensificação na decomposic̣ão dos resíduos vegetais incorporados no perfil.

Também em média para manejos, a distribuição dos nutrientes, do $\mathrm{pH}$ e da matéria orgânica no perfil do solo foi estatisticamente significativa. Observou-se decréscimo, em profundidade, dos teores de $\mathrm{Ca}$, $\mathrm{Mg}, \mathrm{Al}, \mathrm{P}, \mathrm{K}, \mathrm{Zn}$ e $\mathrm{Mn}$, e da matéria orgânica, e elevação do $\mathrm{pH}$ e teores de $\mathrm{Cu}$ e $\mathrm{Fe}$, principalmente nos perfís mais profundos.

Houve efeito significativo da interação entre manejo e profundidade para o $\mathrm{Ca}, \mathrm{Cu}$ e $\mathrm{Mn}$. No preparo do solo com aivecas, a distribuição de Ca e $\mathrm{Mn}$ no perfil foi relativamente homogênea. Já para o $\mathrm{Cu}$ a distribuição relativamente mais homogênea, pode ter ocorrido mais provavelmente por inadequação amostral, que pela diluição do acumulado superficialmente. Os dados referentes à interação do manejo dentro de profundidade foram inconsistentes (Apêndices 6, 7 e 8). 


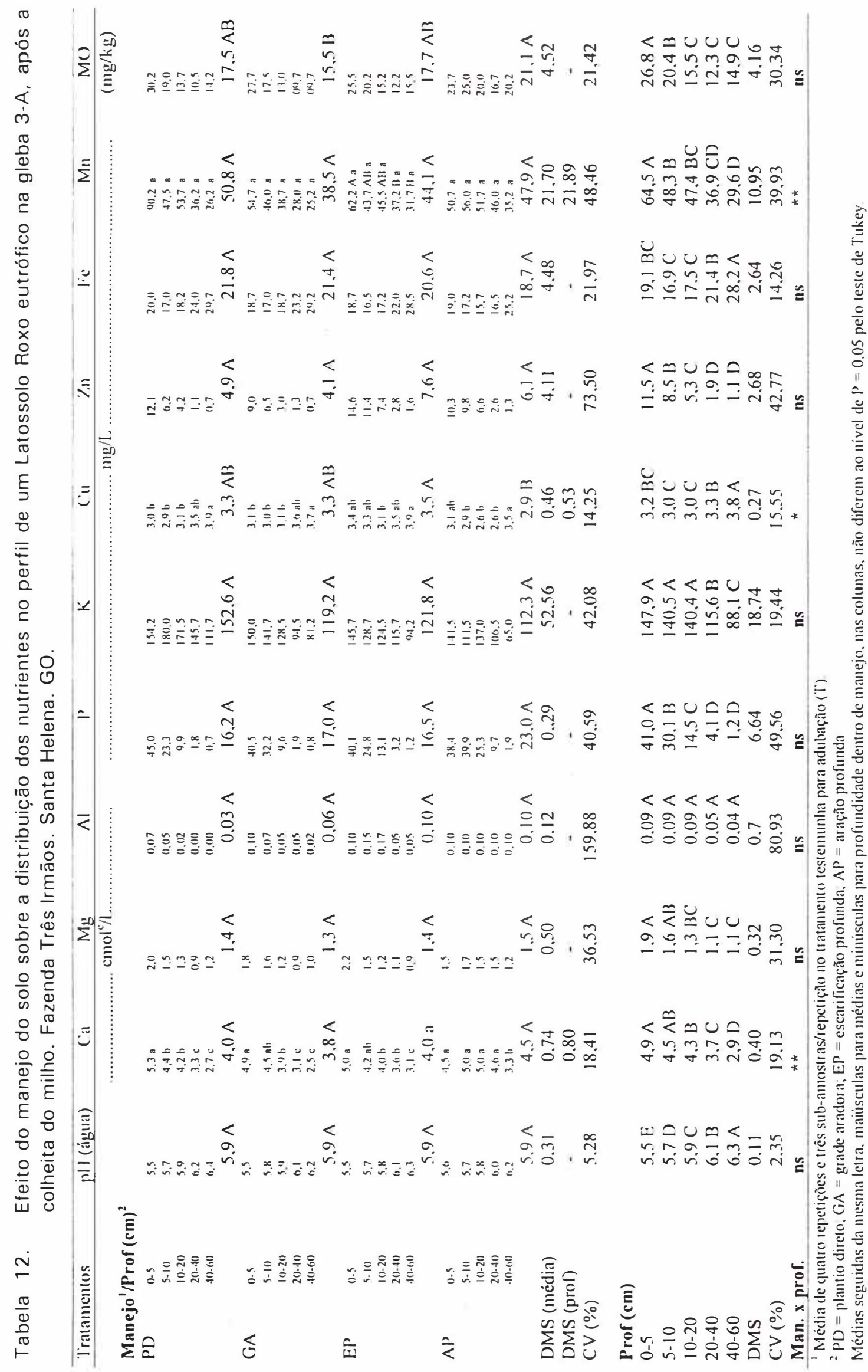


Após a colheita da soja (Tabela 13), não se verificou efeito do manejo do solo sobre o teor, em média para profundidade, de $\mathrm{Mg}, \mathrm{Al}, \mathrm{P}, \mathrm{K}$, $\mathrm{Zn}, \mathrm{Fe}, \mathrm{Mn}$ e matéria orgânica, nem no $\mathrm{pH}$. O teor de Ca foi reduzido no manejo do solo com aivecas, tendo este manejo, juntamente com a escarificação, aumentado o teor de Cu.

Em profundidade, o teor médio dos nutrientes, bem como da matéria orgânica e do $\mathrm{pH}$, foram diferenciados estatisticamente, observando-se as mesmas tendências verificadas nas análises realizadas após a colheita do milho. Houve efeito interativo entre manejo e profundidade para o $\mathrm{Mg}, \mathrm{K}$ e $\mathrm{Zn}$. O Mg e $\mathrm{Zn}$ foram melhor distribuídos no perfil do solo, o mesmo sendo verificado para o $\mathrm{K}$. Porém, verifica-se também a inconsistência dos dados, devido, provavelmente, à metodologia de amostragem, entre os manejos do solo com aiveca e o plantio direto. As interações referentes à profundidade dentro de manejo foram também inconsistentes (Apêndices 9, 10 e 11).

Após a colheita do arroz (Tabela 14), a análise do solo revelou efeito significativo do manejo sobre os teores médios de $\mathrm{Mg}, \mathrm{K}, \mathrm{Zn}$ e $\mathrm{Mn}$, havendo redução dos três primeiros no preparo do solo com aivecas. Para o $\mathrm{Mn}$, o maior teor médio foi verificado no plantio direto. Em relação à distribuição dos nutrientes, da matéria orgânica e do pH no perfil, considerando médias de manejo, observou-se comportamento semelhante às análises após o milho e a soja.

Houve interação significativa entre manejo e profundidade para $\mathrm{Mg}, \mathrm{P}, \mathrm{K}, \mathrm{Zn}, \mathrm{Mn}$ e matéria orgânica, verificando-se a melhor distribuição desses nutrientes no perfil no manejo com arado de aivecas. As interações entre manejos e profundidade são mostradas nos Apêndices 12, 13, 14, 15 , 16 e 17, onde verificou-se relativa inconsistência nos dados. Entretanto, 


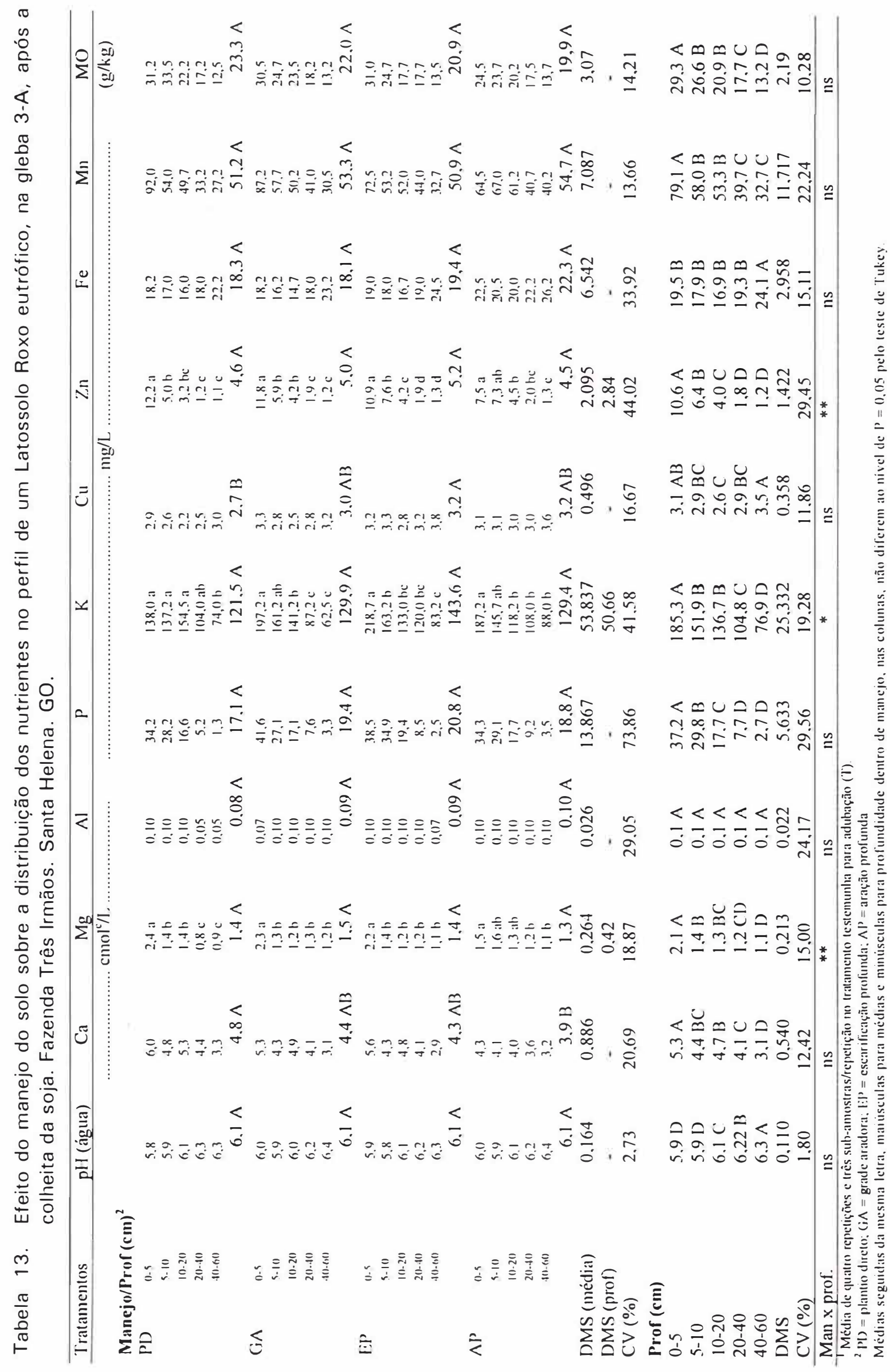




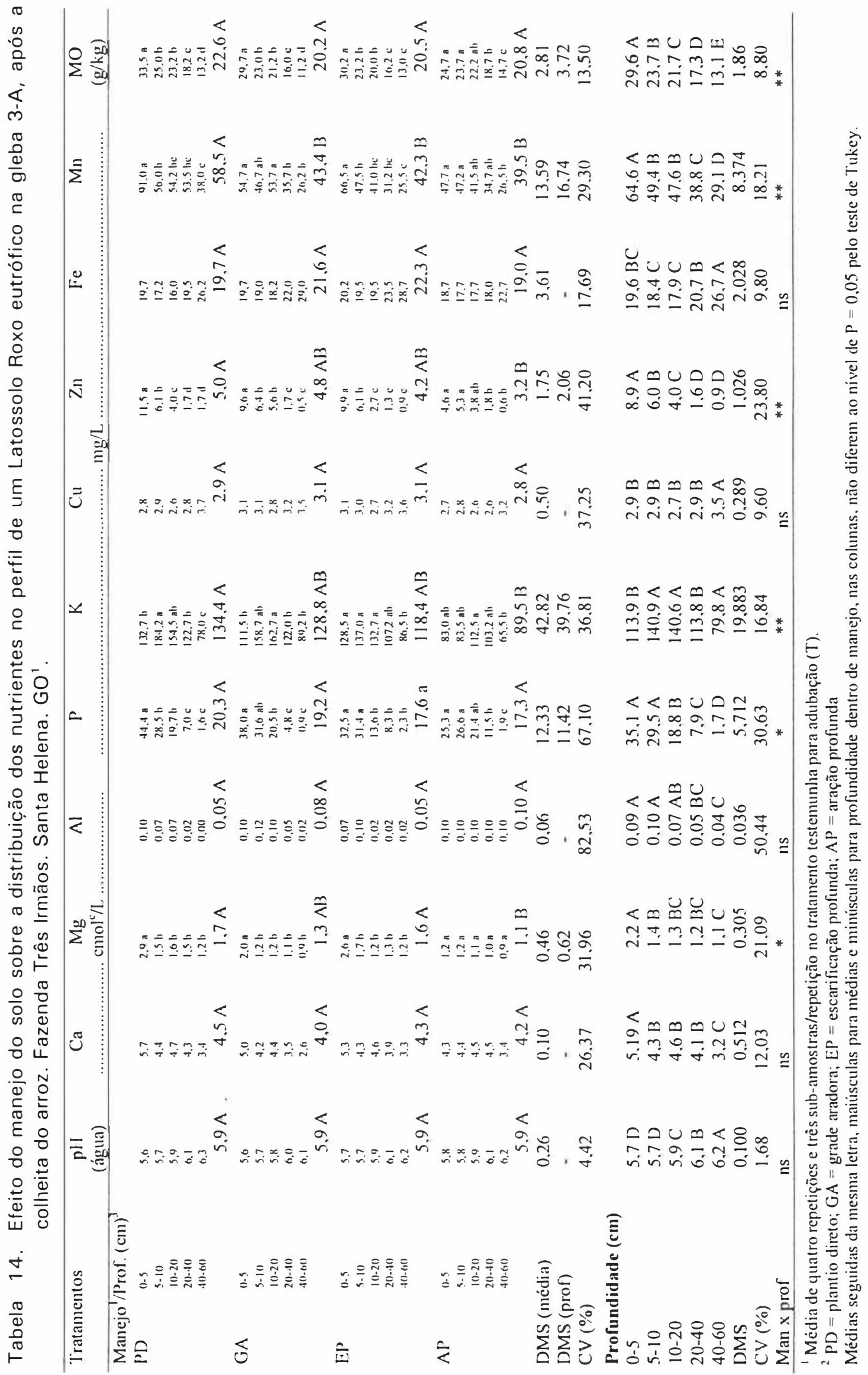


ficaram evidentes a concentração superficial do $\mathrm{Mg}, \mathrm{P}, \mathrm{K}, \mathrm{Zn}, \mathrm{Mn}$ e da matéria orgânica, principalmente no plantio direto, e parcial diluição no perfil devido a aração, tendo sido os valores obtidos, intermediários para a grade aradora e a escarificação.

Após a colheita do feijão, em sucessão ao arroz (Tabela 15), não se verificou efeito do manejo sobre nenhum dos componentes da fertilidade química do solo.

Em profundidade, prevaleceram as tendências observadas para as culturas do milho, soja e arroz. Também não se registrou efeito da interação entre manejo e profundidade na distribuição dos nutrientes.

Na maioria dos casos, as análises estatísticas revelaram alto coeficiente de variação, tanto nos teores como na distribuição dos nutrientes no perfil do solo, devendo-se esta variação, acima de tudo, à metodologia utilizada para a amostragem do solo, com número insuficiente de subamostras. Tal verificação indica que são necessárias alterações na metodologia de amostragem de solo para o sistema de plantio direto, bem como após o manejo do solo mantido com este sistema por longo período e que, simultâneamente, apresente média a alta fertilidade.

\subsection{Comportamento de algumas propriedades físicas do solo sob os diferentes manejos}

Alguns atributos físicos do solo foram avaliados após a colheita do arroz e do feijão em sucessão, no tratamento Eg para adubação. 


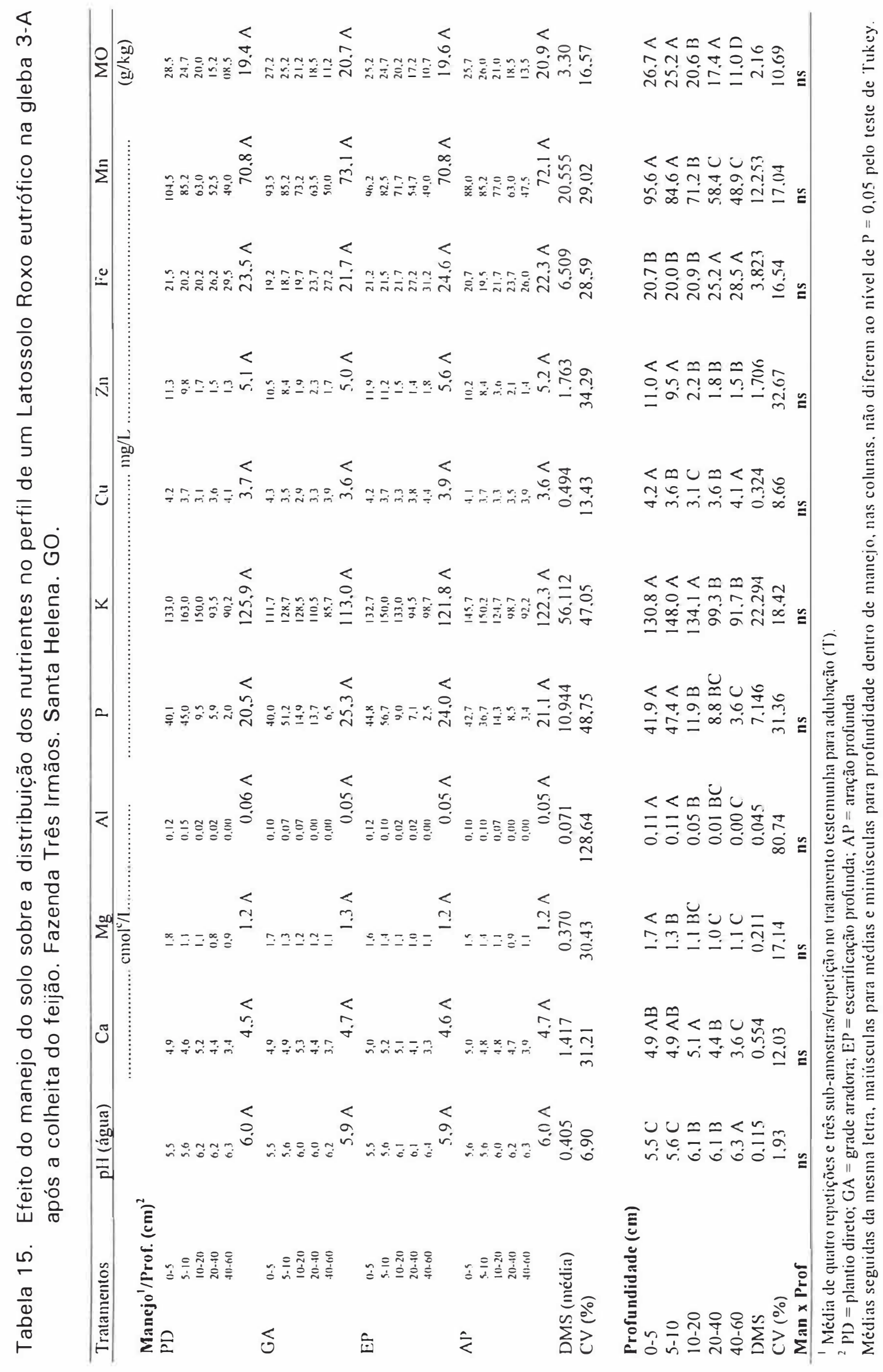


Após a colheita do arroz, cerca de 5 meses após o preparo, a aivecagem seguida da escarificação proporcionou os menores valores de massa específica do solo (Tabela 16 e Figura 4) e maiores de macroporosidade, até aproximadamente $40 \mathrm{~cm}$ de profundidade. No preparo com aiveca, também verificou-se um aumento relativo na microporosidade e porosidade total, juntamente com a escarificação. No plantio direto e preparo com grade aradora, registrou-se relativo adensamento/compactação nos perfís entre 5 e $40 \mathrm{~cm}$ de profundidade.

Em relação à profundidade, em média para o manejo, apenas a massa específica do solo no perfil $40-60 \mathrm{~cm}$, não mobilizado pelos implementos, foi significativamente superior aos perfís superficiais. O comportamento destes parâmetros no perfil do solo preparado com grade aradora foi bastante semelhante ao verificado no plantio direto.

Após a colheita do feijão, cerca de 12 meses após o preparo, também não se verificou efeito do manejo sobre a média de nenhum destes parâmetros físicos, havendo, no entanto, efeito significativo para macroporosidade, porosidade total e massa específica do solo em profundidade (Figura 4 e Tabela 17). Nos manejos com revolvimento do solo, a macroporosidade e a porosidade total foram superiores apenas nos perfís superficiais, até $10 \mathrm{~cm}$ de profundidade. A massa específica do solo aumentou nos perfís anteriormente descompactados e a porosidade foi reduzida a valores semelhantes aos registrados no plantio direto, denotando curta duração dos benefícios decorrentes da descompactação do solo com aivecas ou escarificação.

A ausência de efeito do manejo do solo, em média para profundidade, sobre a macro e microporosidade, porosidade total e massa especifica do solo, também foi observada nas pesquisas desenvolvidas por 


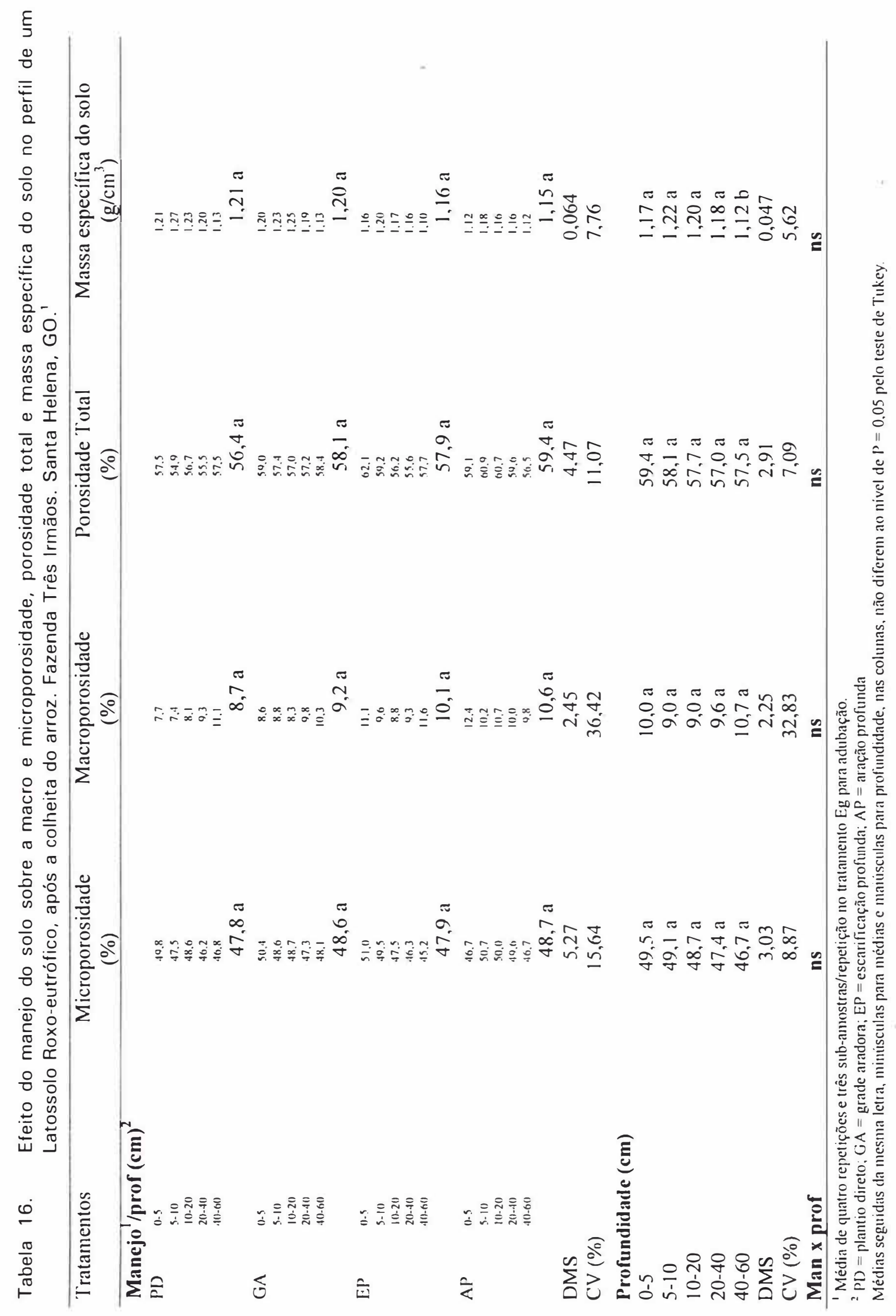




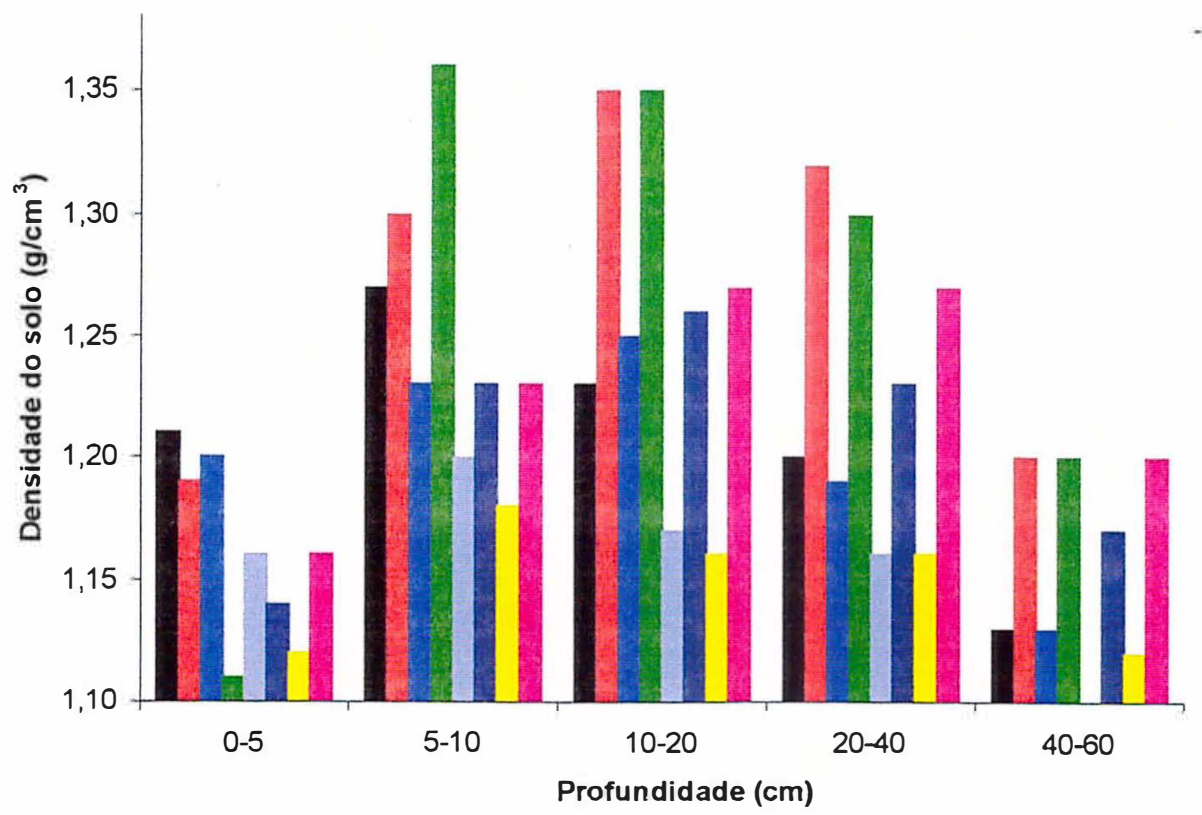

$\begin{array}{llll}\square \text { PD 14/02/97 } & \text { GA 14/02/97 } & \text { EP 14/02/97 } & \text { AP 14/02/97 } \\ \text { PD 09/09/97 } & \square \text { GA 09/09/97 } & \text { EP 09/09/97 } & \text { AP 09/09/97 }\end{array}$

Figura 4. Efeito dos sistemas de plantio direto (PD), grade aradora (GA), escarificação (EP) e aração (AP) sobre a massa específica no perfil do solo após a colheita do arroz (14/02/97) e do feijão em sucessão (09/09/97). Fazenda Três Irmãos. Santa Helena. GO. 


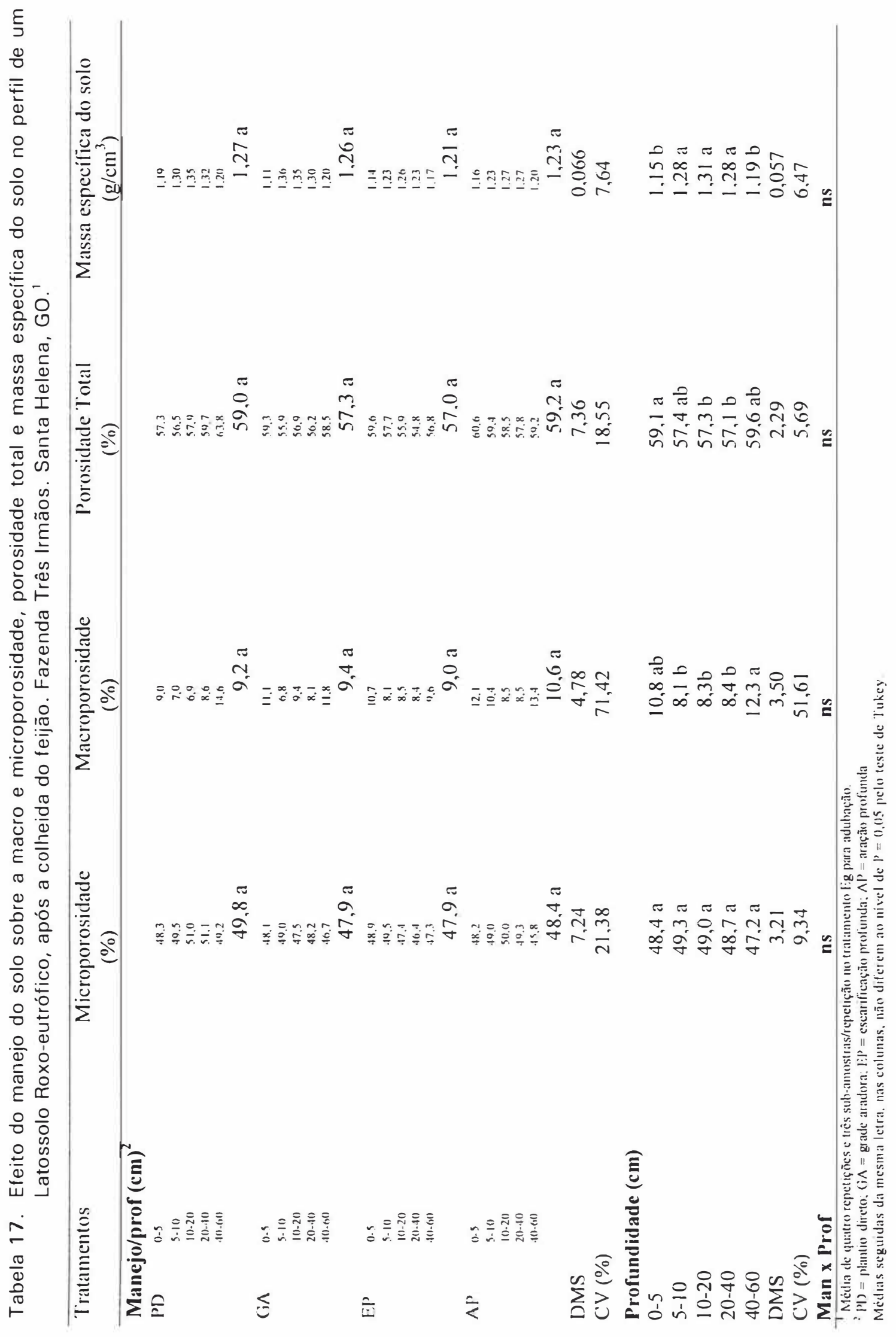


Fernandes et al. (1983), Albuquerque et al. (1995) e Urchei (1996). Vários autores, no entanto, têm mostrado que o solo mantido sob plantio direto, geralmente apresenta maiores valores de massa específica do solo e macroporosidade nas camadas superficiais do perfil. Esta situação corresponde também à diminuição nos valores de macroporosidade e porosidade total, muito provavelmente devido ao rearranjamento das partículas do solo e a movimentação de máquinas e implementos agrícolas (Vieira \& Muzilli, 1984; Moreira et al., 1995).

A estabilidade dos agregados também foi avaliada no tratamento Eg para adubação, apenas após a colheita do arroz, ou seja, cinco meses após o preparo. Não foi observada diferença entre manejos na média de distribuição dos agregados. Já em profundidade, houve registro (Tabela 18). O preparo com grade aradora e o plantio direto apresentaram, em média para manejo, maior percentual de agregados com diâmetro igual ou superior a $2 \mathrm{~mm}$, no perfil $0-5 \mathrm{~cm}$, enquanto o preparo com aiveca apresentou maiores valores no perfil $5-20 \mathrm{~cm}$ de profundidade. Muzilli (1984) e Campos et al. (1995), também verificaram percentual mais alto de agregados maiores estáveis em água no sistema de plantio direto. Para os agregados entre $1 \mathrm{~mm}$ e $0,5 \mathrm{~mm}$, o plantio direto e a escarificação apresentaram os maiores percentuais entre 5 e $20 \mathrm{~cm}$ de profundidade, e para agregados menores que $0,5 \mathrm{~mm}$ não houve diferença na distribuição média, nas diferentes profundidades em função dos manejos. Segundo Harris et al. (1966), a cobertura morta e seus resíduos protegem os agregados da superfície do solo contra a desagregação causada pelo impacto das chuvas. 


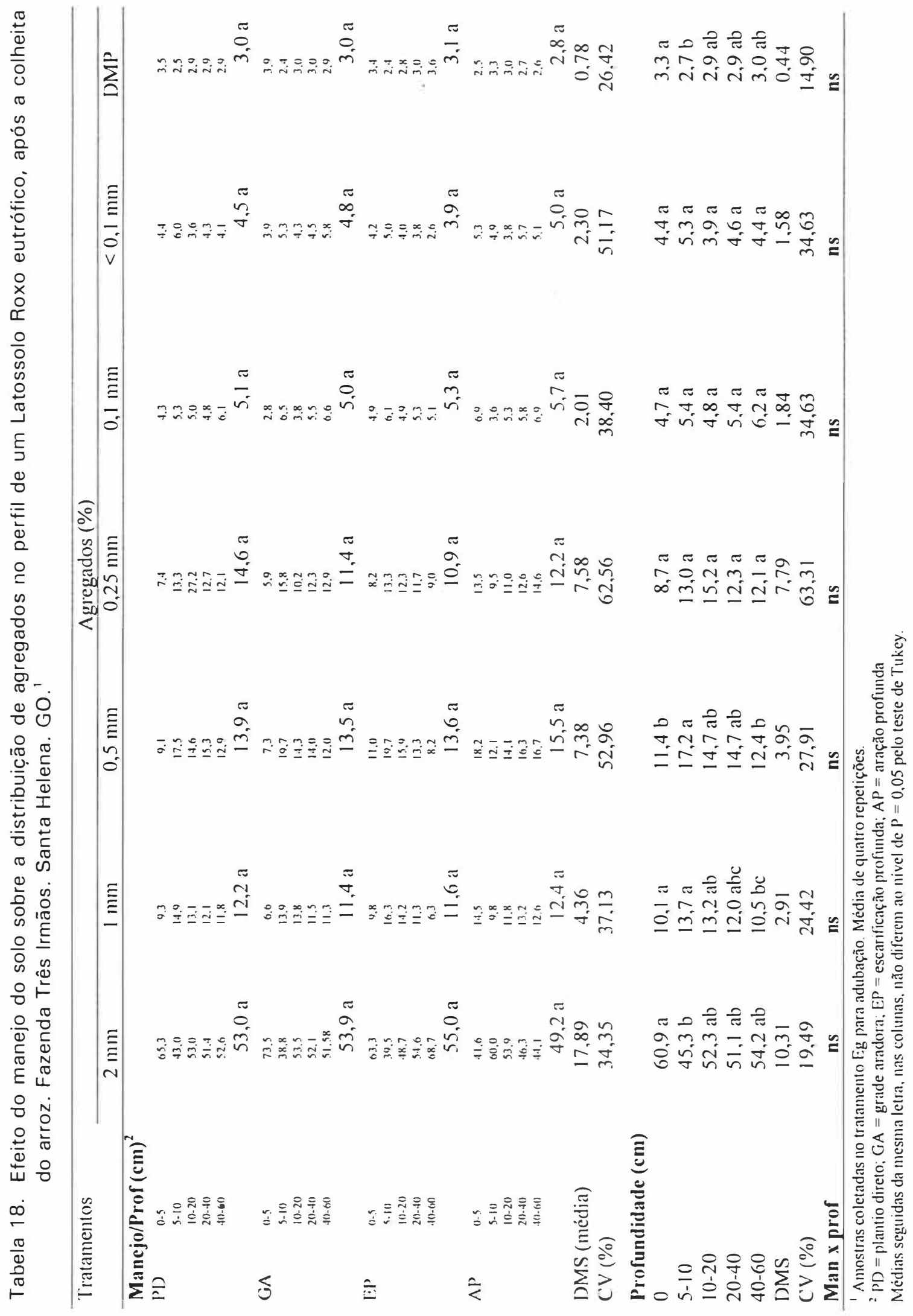


O contínuo aporte de matéria orgânica por secreções radiculares, nas renovações do sistema radicular e da parte aérea, e ainda os resíduos das colheitas, estimulam a atividade biológica do solo. Os produtos finais desta interação, em diferentes etapas da decomposição, funcionam como agentes de formação e estabilização dos agregados.

O diâmetro médio ponderado (DMP) dos agregados também não foi afetado pelo manejo, tendo sido, contudo, alterado em profundidade, onde maiores valores foram encontrados na superfície nos sistemas de plantio direto, grade aradora e escarificação. Na aivecagem, os maiores valores situaram-se no perfil $5-20 \mathrm{~cm}$ de profundidade. De qualquer maneira, os valores de DMP no perfil sob os diferentes manejos são inconsistentes. Muzilli (1984) e Urchei (1996) encontraram maiores valores de DMP no plantio direto, principalmente nos primeiros $10 \mathrm{~cm}$, em relação ao manejo convencional do solo.

Segundo Kiehl (1979), não foram estabelecidos números absolutos para interpretar, através dos resultados de análise de agregação, quando o solo pode ser considerado de boas ou más propriedades físicas, aceitando-se, de modo geral, como sendo de baixa estabilidade, os solos com DMP abaixo de 0,5 mm. Neste contexto, os resultados obtidos encontram-se na faixa admissível, sendo contudo, inferiores aos obtidos por Muzilli (1984) e semelhantes aos de Urchei (1996), ambos determinados em Latossolo. 


\subsection{Manejo do solo e alguns aspectos microbiológicos}

O papel dos microrganismos e da mesoforma no melhoramento das propriedades do solo e as vantagens da cobertura morta e da matéria orgânica sobre suas populações e atividade são inquestionáveis. As tabelas 19 e 20 mostram, quase sempre, larga diferença da atividade microbiológica e populações totais de fungos e bactérias no sistema de plantio direto em relação aos manejos que revolvem o solo. Dados mostrando tendência semelhante foram também encontrados por Costa \& Silveira (1997) e Berni et al. (1997). Segundo Costa (1997b) altas populações de fungos e bactérias tendem ao equilíbrio, reduzindo a possibilidade de proliferação demasiada de microrganismos patogênicos. Ainda assim, observa-se que as populações de Fusarium solani Esp. Phaseoli e Rhizoctonia solani, cerca de 80 dias após o manejo, foram significativamente superiores no plantio direto, em níveis capazes de causar redução na população final de plantas devido a $R$. solani ou prejudicando o desenvolvimento das plantas, devido à F. solani, segundo pesquisas desenvolvidas por Costa \& Costa (1997) e Berni et al. (1997). O revolvimento do solo com arado de aiveca reduziu o número de propágulos destes microrganismos em cerca de $50 \%$, passando a existir menor probabilidade de causarem danos significativos às plantas. A aração, com conseqüente enterrio dos restos culturais, tem sido recomendada como uma das técnicas de redução destas e outras enfermidades por Cardoso et al. (1996), EMBRAPA (1996), Sartorato et al. (1996); EMBRAPA (1997b); Costa (1997a).

Na cultura da soja, a infestação de Roselinea sp. foi bastante superior nos manejos com conservação da palhada na superfície, ou superficialmente incorporada através da grade aradora. 


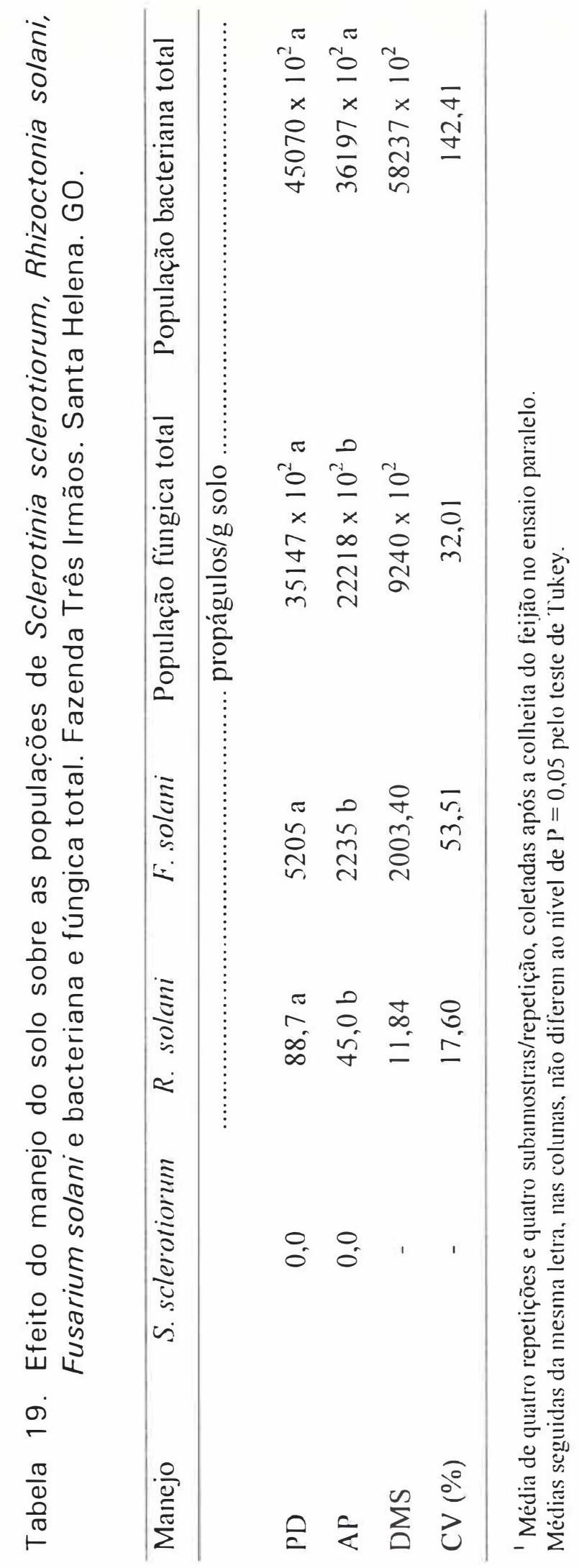




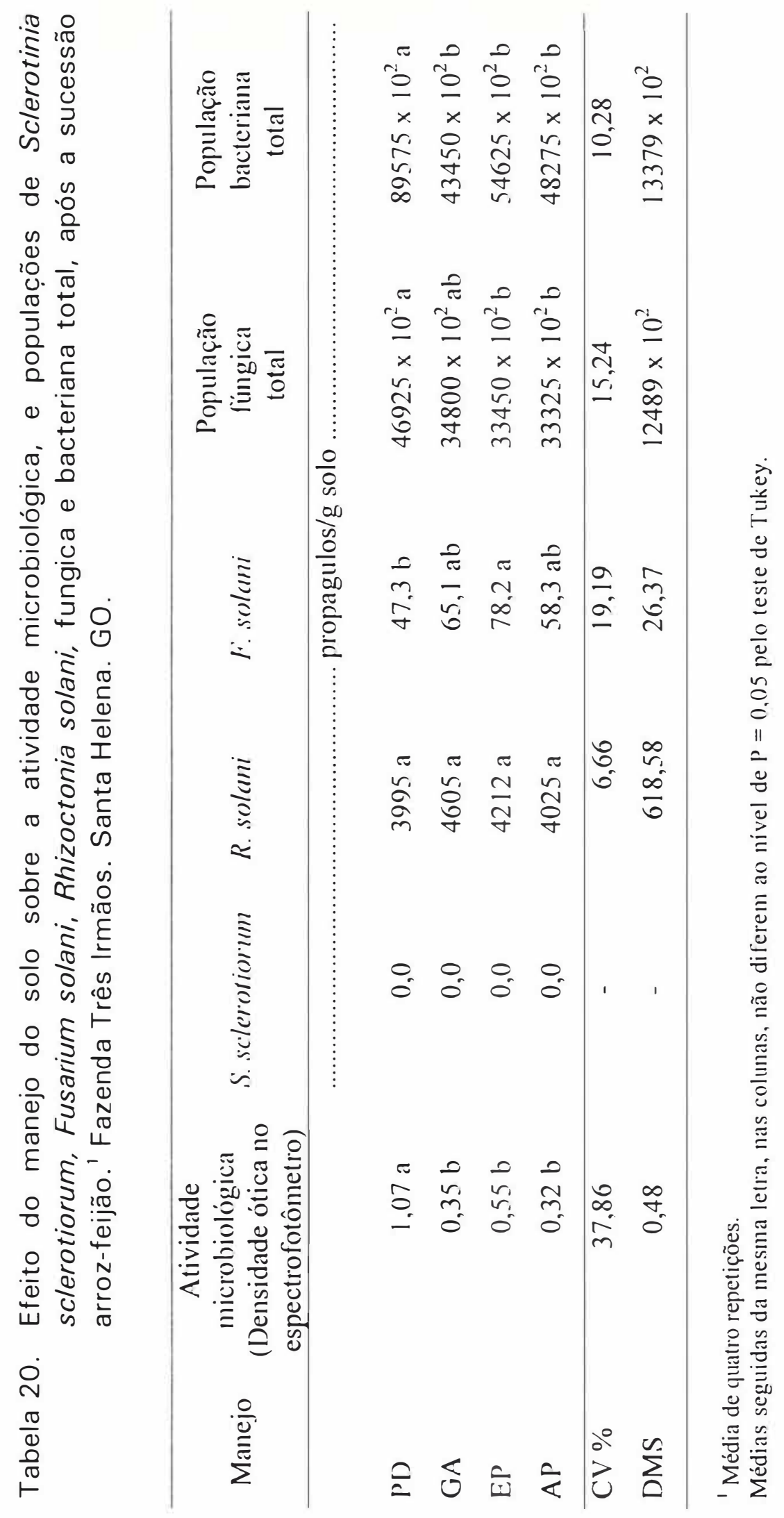


O lado negativo da inversão do solo, entretanto, é o de reduzir também a atividade microbiológica do solo e principalmente, a população bacteriana por longo período de tempo, como mostra a tabela 20 , cerca de um ano após o preparo. Neste período, as populações dos fungos patogênicos também voltam a se restabelecer, inclusive em níveis superiores ao plantio direto em todos os manejos que revolveram o solo.

Nas condições dos experimentos, o aspecto mais negativo da manutenção da palhada na superfície, com conseqüente aumento no teor de matéria orgânica, foi a manutenção de altas concentrações de fungos patogênicos, tal qual a Rhizoctonia solani, ocasionando acentuada redução na população final de plantas, principalmente das leguminosas mais susceptíveis a este patógeno (Tabela 21). Redução na população final de plantas no sistema de plantio direto também foi observada por Stone \& Moreira (1995). O feijoeiro sofreu as maiores reduções, chegando a $42 \%$ na escarificação e $36 \%$ no plantio direto e preparo com grade aradora. A menor redução, observada no manejo com aiveca, pode ser atribuída à sua rápida proliferação na camada superficial do solo.

Na cultura de soja, as reduções na população final chegaram a atingir $27 \%$ nos sistemas de plantio direto e grade aradora. Na cultura do milho, as reduções foram bem menores, sendo bastante semelhantes para os diferentes manejos. Na cultura do arroz, não se avaliou o número de perfilhos por planta por ocasião do florescimento, porém o número final deste foi bastante pequeno, em média de 1,54/planta, se for considerada a possibilidade de sobrevivência de todas as plantas emergidas. Este resultado indica redução do número de plantas entre a emergência e a colheita. 


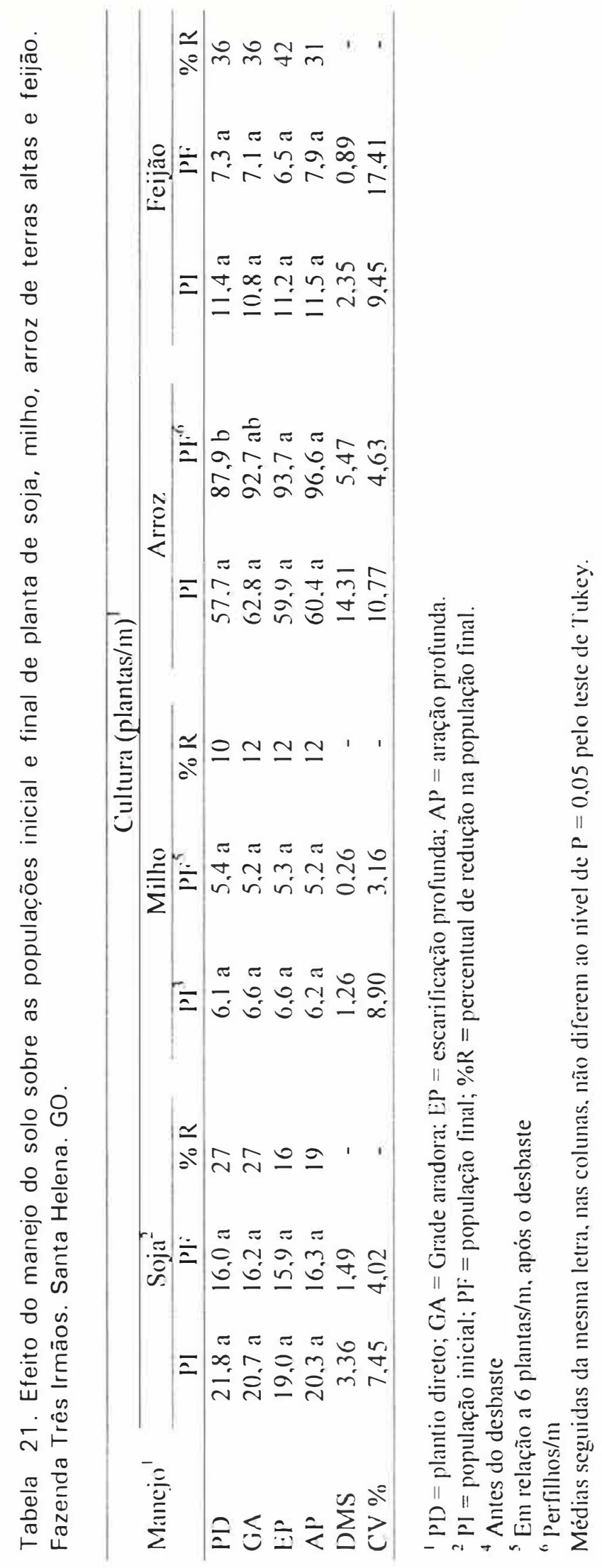




\subsection{Concentração de nutrientes nas folhas das culturas em função do manejo do solo}

Os níveis da maioria dos macro e micronutrientes acumulados nas folhas do milho estão dentro da faixa de suficiência, se comparados aos valores extraídos de Raij (1991) e Büll (1993), exceto para o B, cuja concentração foliar situou-se pouco abaixo do intervalo adequado (Tabela 22). O manejo do solo afetou significativamente o acúmulo foliar do $\mathrm{P}, \mathrm{Mg}$, $\mathrm{Zn}, \mathrm{Cu}, \mathrm{Fe}$ e B. De modo geral, as plantas concentraram maiores níveis de nutrientes nas folhas no sistema de plantio direto, desconsiderando as diferenças observadas no acúmulo de matéria seca.

O revolvimento do solo com arado de aivecas ou grade aradora resultou em menores concentrações de $\mathrm{P}, \mathrm{Zn}, \mathrm{Cu}$ e $\mathrm{B}$, elevando, no entanto, a concentração de $\mathrm{Mn}$ e Fe. No manejo com aivecas, entretanto, registrou-se a maior concentração de matéria seca. Os valores referentes aos manejos com grade aradora e escarificação mantiveram-se, quase sempre, em níveis intermediários, exceto para o $\mathrm{N}$ e Fe, cuja concentração foi ligeiramente superior. Não foi observado efeito significativo da adubação sobre a concentração foliar dos nutrientes.

A interação entre manejo do solo e adubação foi significativa apenas para o $B$, sendo que a menor concentração foi observada na ausência de adubação fosfatada e potássica, sendo menor, também, no manejo do solo com arado de aivecas (Apêndice 18). 


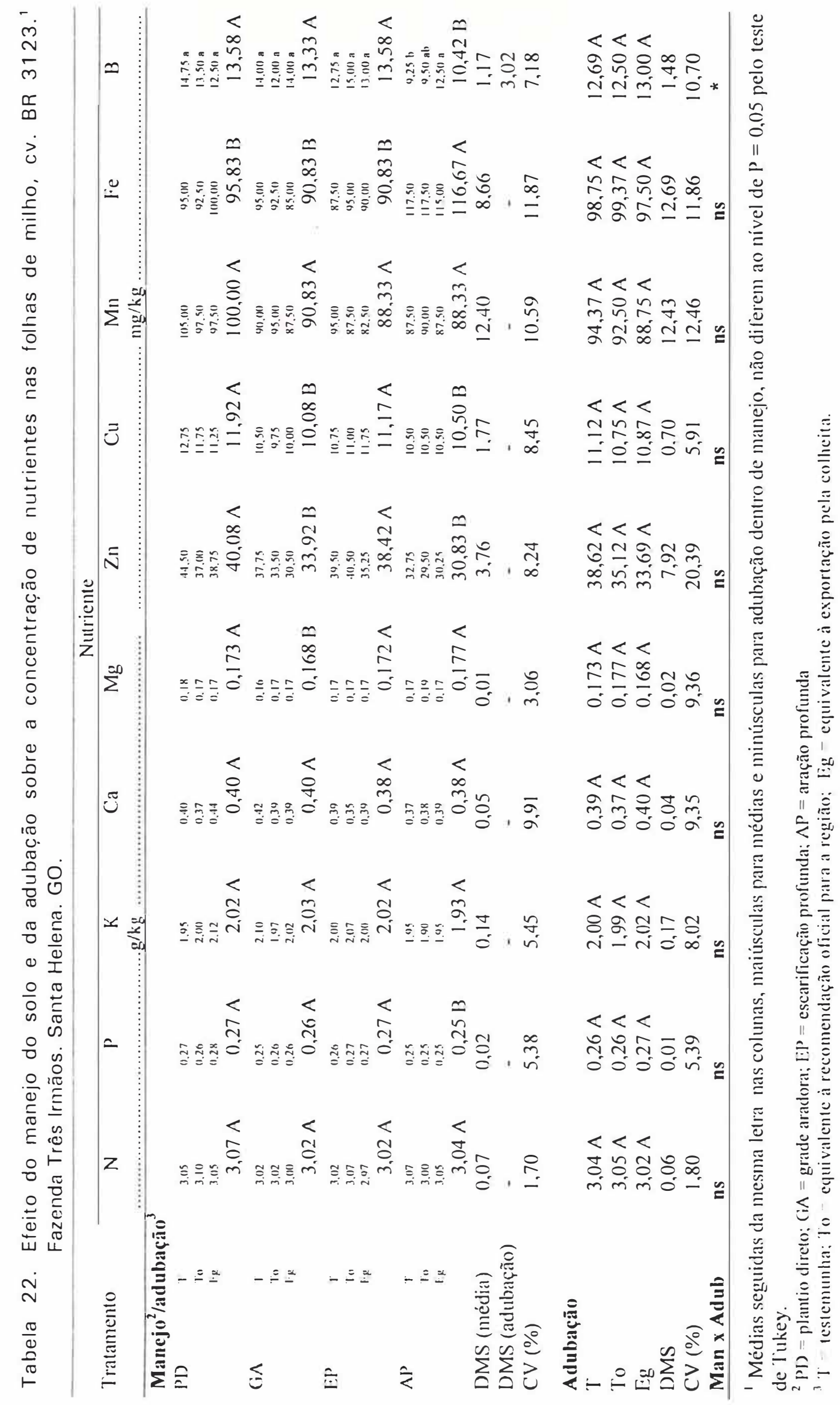


Nas folhas de soja, apenas a concentração de $\mathrm{P}$ e $\mathrm{Cu}$ ficaram ligeiramente abaixo do intervalo de suficiência de acordo com intervalos de suficiência foliar propostas por Peck (1979), extraído de Raij (1991) e Oliveira \& Cassol (1995) (Tabela 23). As concentrações foliares de N, P, Mg, Zn, Mn e Fe não foram afetadas pelo manejo do solo, enquanto o preparo com grade aradora reduziu o teor de $\mathrm{K}$, Cu e $\mathrm{B}$, e o plantio direto, de $\mathrm{Ca}$.

De forma similar ao milho, os níveis de adubação não afetaram o teor médio de nutrientes nas folhas de soja, exceto para o $\mathrm{Mn}$, cuja concentração foi reduzida com o aumento da adubação potássica.

A interação entre manejo e adubação foi significativa para o $\mathrm{Cu}$ e B (Apêndices 19 e 20). O teor foliar de Cu foi inferior quando em presença do maior nível de adubação potássica, especialmente no solo preparado com aração profunda, e do maior nivel de adubação fosfatada na escarificação. O preparo do solo com grade aradora, resultou na menor concentração foliar deste micronutriente. $O$ teor de $B$ foi superior no manejo do solo com escarificação exceto no nível mais alto de adubação potássica.

$\mathrm{Na}$ cultura do arroz, exceto para o $\mathrm{Cu}$ e $\mathrm{Mn}$, a concentração foliar dos demais macro e micronutrientes ficou abaixo do intervalo de suficiência proposto por Malavolta et al. (1989), não havendo uma explicação lógica já que trata-se de solo com alta disponibilidade dos nutrientes. O manejo do solo com arado de aivecas elevou significativamente o teor foliar de $\mathrm{N}, \mathrm{Ca}, \mathrm{Zn}, \mathrm{Mn}$ e $\mathrm{B}$, e também resultou no maior acúmulo de matéria seca. Já com relação ao $P$, o maior teor ocorreu no plantio direto. Não houve interferência do manejo do solo sobre a concentração foliar média de $\mathrm{K}, \mathrm{Mg}, \mathrm{Cu}$ e $\mathrm{Fe}$. Os níveis de adubação fosfatada e potássica não influenciaram no teor foliar de $\mathrm{N}, \mathrm{Ca}, \mathrm{Mg}, \mathrm{Cu}, \mathrm{Mn}$, Fe e B, ocorrendo, contudo, redução no caso do $P, K$ e $Z n$ (Tabela 24). 


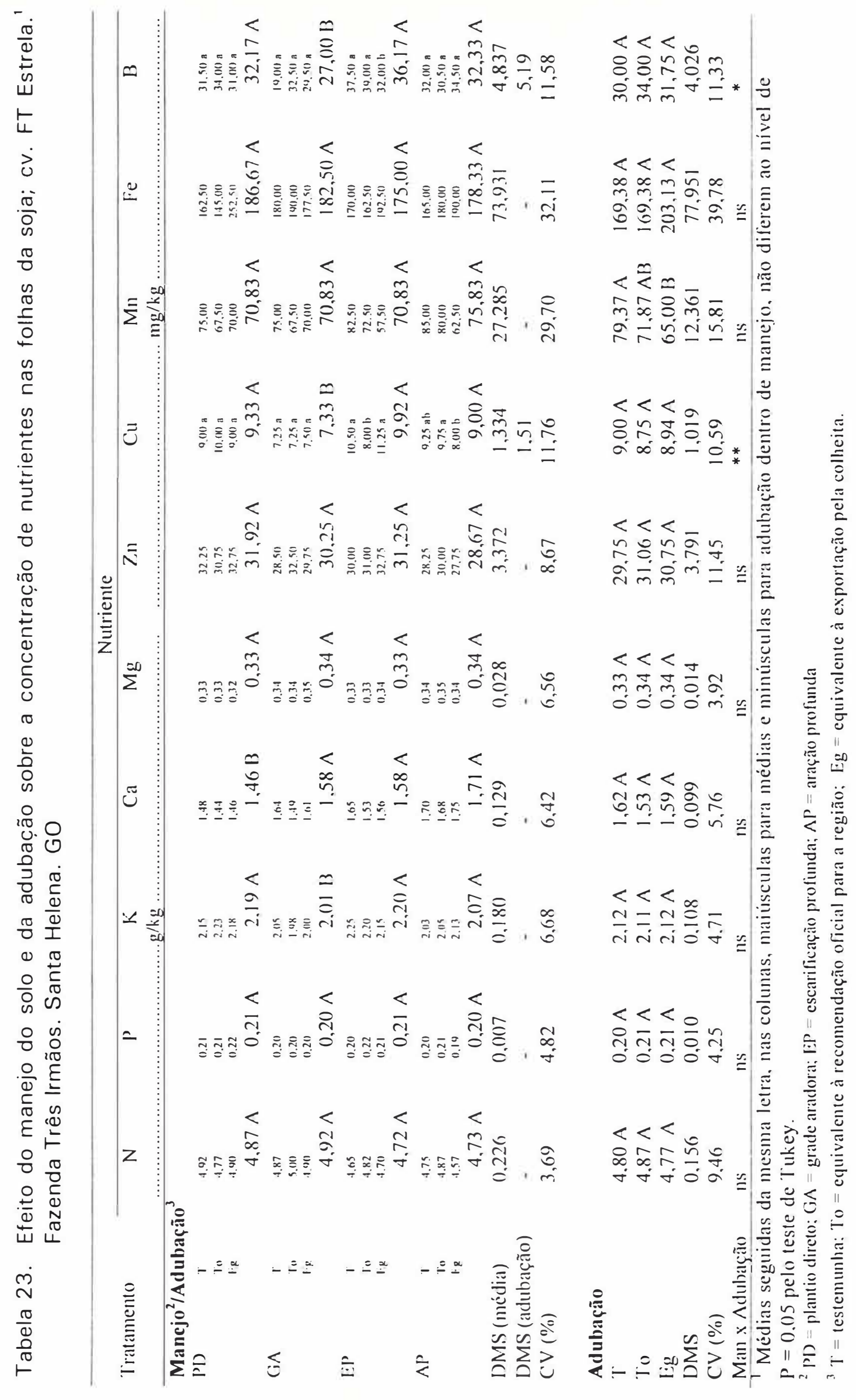




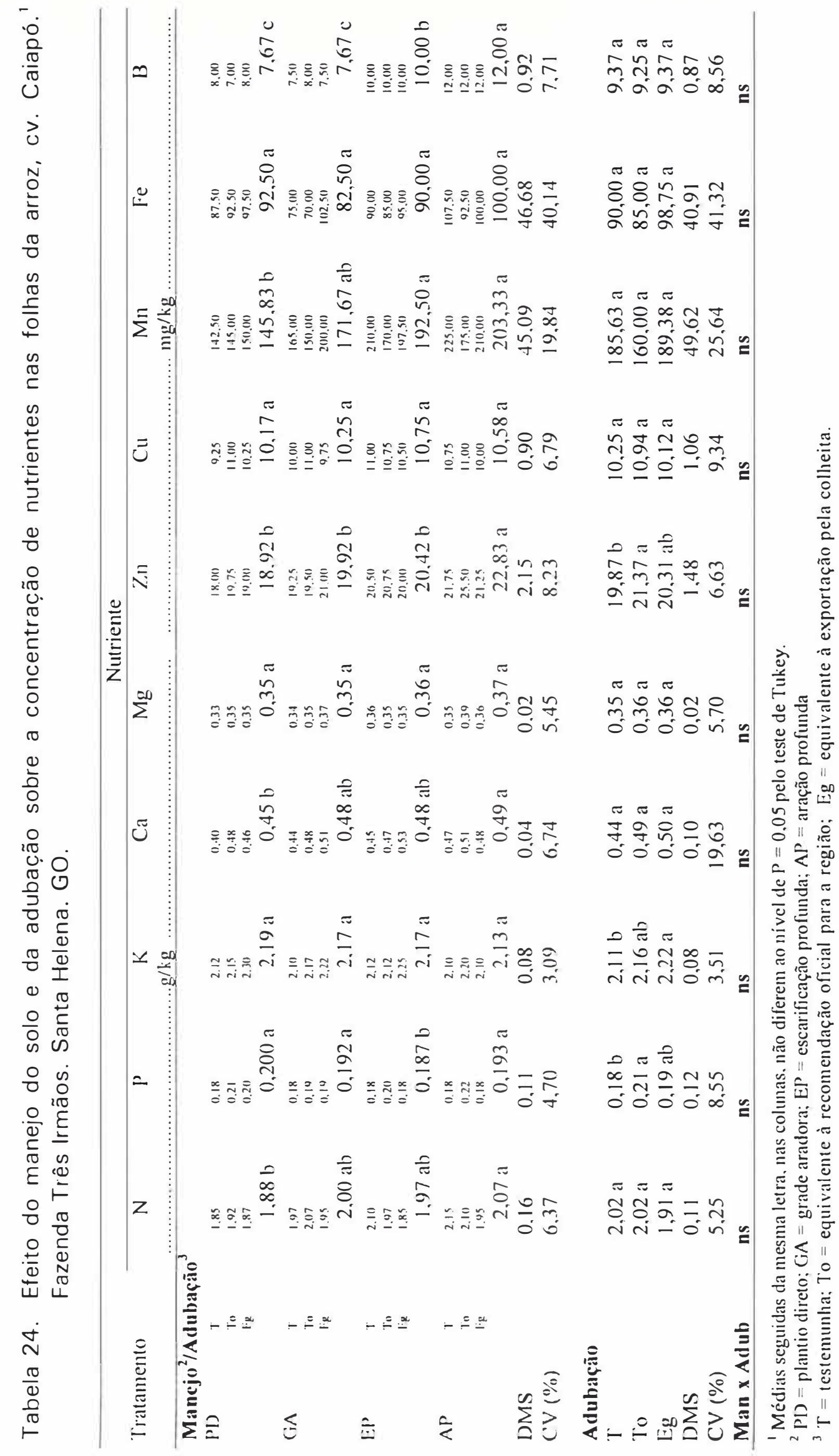


Para o feijoeiro, a concentração de macro e micronutrientes nas folhas está dentro da faixa de suficiência descrita por Vitosh et al. (1978) e Piggott (1986). O manejo do solo afetou, em média para os níveis de adubação, o teor de $\mathrm{P}, \mathrm{K}, \mathrm{Mg}, \mathrm{Zn}, \mathrm{Cu}, \mathrm{Mn}, \mathrm{Fe}$ e B. $\mathrm{Na}$ aração com aivecas e escarificação registraram-se reduções na concentração de $\mathrm{P}, \mathrm{K}, \mathrm{Mg}, \mathrm{Zn}, \mathrm{Cu}$, $\mathrm{Mn}$ e $\mathrm{Fe}$, e aumento para o $\mathrm{B}$, em relação à grade aradora e ao plantio direto (Tabela 25). Os níveis de adubação não influenciaram, em média para manejo, a concentração foliar dos nutrientes avaliados, exceto o $\mathrm{Cu}$, cujo teor foliar elevou-se no caso de níveis mais altos de adubação fosfatada e potássica.

O maior acúmulo de $\mathrm{N}$, em geral, ocorreu na escarificação e plantio direto, independente do nível de adubação fosfatada e potássica (Apêndice 21).

De modo geral, os resultados referentes à concentração de nutrientes nas folhas das culturas, mostram que, independente da variabilidade encontrada na distribuição dos nutrientes no solo, especialmente para $\mathrm{P}$ e $\mathrm{K}$, ainda que dentro da faixa adequada, a planta extrai do solo e acumula apenas as quantidades suficientes para o seu adequado metabolismo.

Exceto para o arroz de terras altas, a concentração foliar de nutrientes estava dentro da faixa de suficiência. Este comportamento indica que o excesso de nutrientes no solo, acima do nível ótimo interpretado nas tabelas convencionais, nem sempre redunda em maior extração e produtividade das culturas, sugerindo a necessidade de revisão e mais estudos sobre as recomendações de adubação para casos de solo e sistemas de manejo similares ao do estudo em questão. 


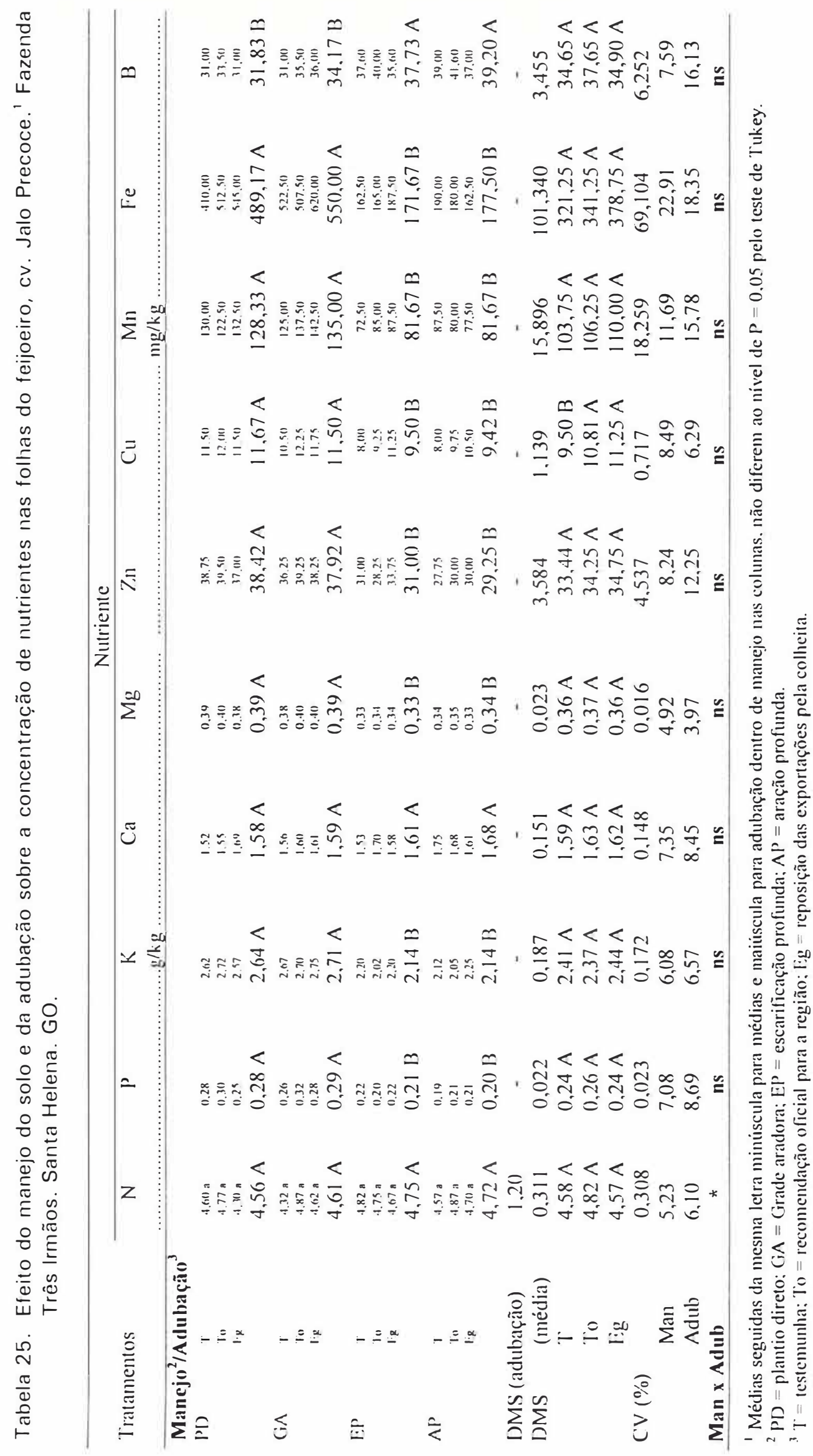




\subsection{Manejo do solo e enraizamento das culturas}

O desenvolvimento radicular das culturas da soja, milho, arroz e feijão foi avaliado no estádio de plena floração, no tratamento testemunha para adubação potássica e fosfatada (Figura 5).

Os diferentes manejos de solo afetaram significativamente 0 volume radicular médio do milho no perfil do solo. A escarificação do solo resultou tanto em maior volume radicular, no perfil $0-100 \mathrm{~cm}$ de profundidade, como em melhor distribuição até os $20 \mathrm{~cm}$ de profundidade (Apêndices 22, 23 e 24), enquanto a grade aradora e o plantio direto apresentaram os piores desempenhos no desenvolvimento radicular do milho. O plantio direto apresentou ligeira tendência ao maior acúmulo superficial das raízes. Abaixo de $20 \mathrm{~cm}$, o desenvolvimento radicular foi muito semelhante em todos os manejos. Tendências parecidas foram relatadas por Manfron et al. (1991) e Choudhury et al. (1991).

Independente do manejo do solo, mais de $66 \%$ das raízes acumularam-se nos primeiros $10 \mathrm{~cm}$ de profundidade e mais de $89 \%$ nos primeiros $20 \mathrm{~cm}$, estando este resultado em concordância com os que foram obtidos por Durieux et al. (1994). A massa seca das raízes revelou a mesma tendência, já que mais de $69 \%$ das raízes concentraram-se nos primeiros 20 $\mathrm{cm}$ de profundidade, independente do manejo, sendo que o preparo com grade resultou em raízes mais fibrosas na superfície e o preparo com aivecas em menos fibrosas (Apêndice 23). Na profundidade entre $60 \mathrm{~cm}$ e $100 \mathrm{~cm}$, encontrou-se menos de $4 \%$ das raízes, concordando com os resultados obtidos por Resende et al., (1990). 

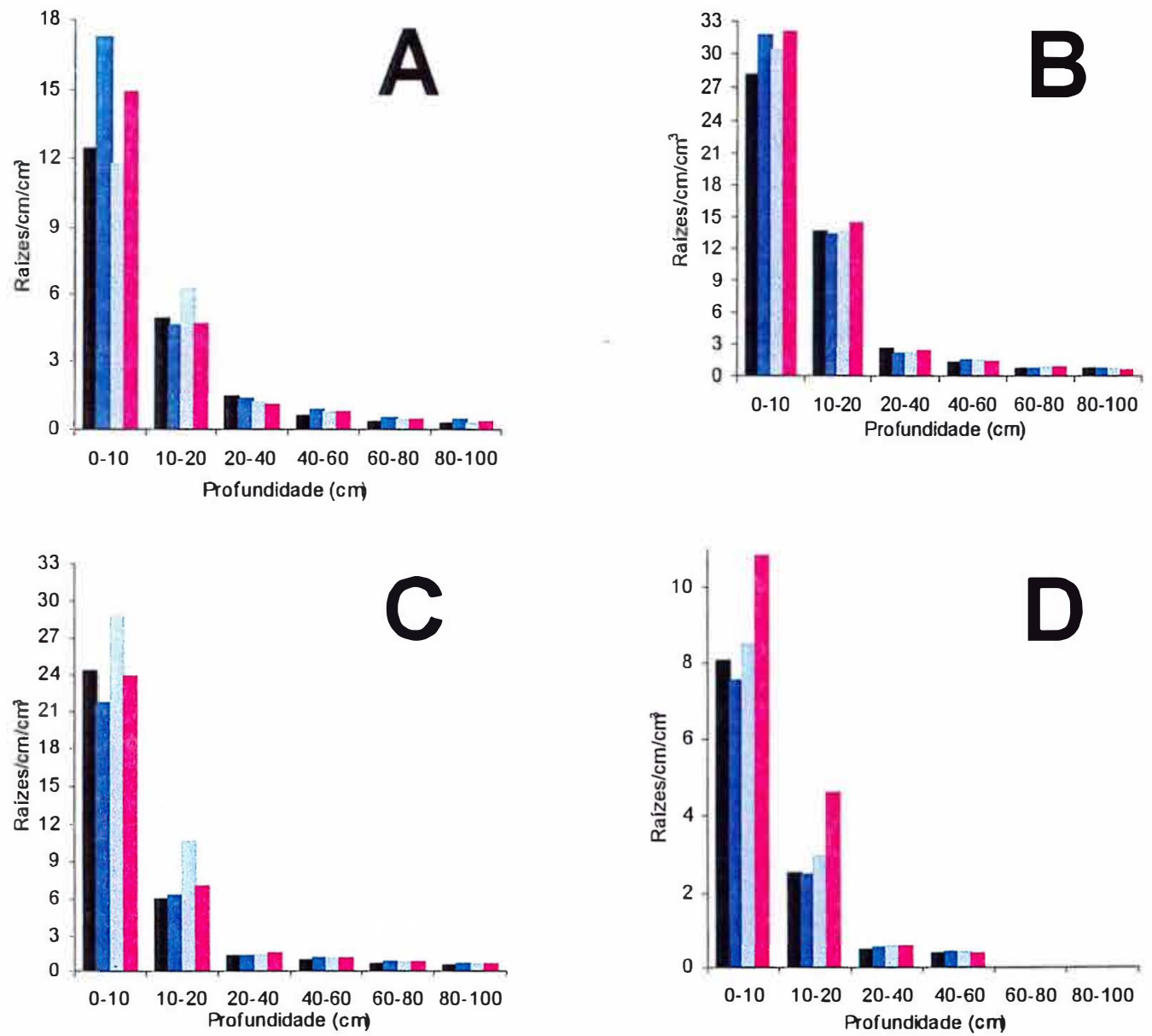

Plantio Direto - PD Grade Aradora - GA

Escarificação Profunda - EP

Aração Profunda - AP

Figura 5. Efeito do manejo sobre a distribuição das raízes das culturas da soja (A), arroz (B), milho (C) e feijão (D) no perfil do solo. Fazenda Três Irmãos. Santa Helena. GO. 
Ainda que o impedimento físico seja considerado o principal fator para o alongamento e a proliferação das raízes (Hughes et al., 1992), a concentração superficial observada no presente estudo pode também ser devida ao excesso de umidade no solo, causado pelo excedente pluviométrico ocorrido nos primeiros estádios de desenvolvimento do milho. Mackay \& Barber (1985) relataram redução no sistema radicular do milho da ordem de $16 \%$ quando o potencial matricial da água no solo passou de $33 \mathrm{kPa}$ para $-7,5 \mathrm{kPa}$. Newell \& Wilhelm (1987) também verificaram melhor enraizamento desta cultura, em profundidade, em solo com menor teor de umidade, sendo contudo, suficiente para o bom desenvolvimento da planta

Na cultura da soja não se observou diferença significativa do manejo do solo sobre o desenvolvimento radicular, havendo, em média, maior volume no manejo do solo com grade aradora, porém com elevada concentração nos primeiros $10 \mathrm{~cm}$ de profundidade (Apêndices 22 e 25). Estes resultados contrastam com os obtidos por Veiga \& Oliveira (1976) e Pedo et al. (1986).

Independente do manejo do solo, mais de $57 \%$ das raízes acumularam-se no perfil $0-10 \mathrm{~cm}$ de profundidade e mais de $87 \%$ nos primeiros $20 \mathrm{~cm}$, contrastando também com as conclusões de Maia \& Eltz (1992) e Cardoso (1993). Tendência ao maior acúmulo no perfil $10-20 \mathrm{~cm}$ foi verificada no manejo com escarificação e, abaixo de $60 \mathrm{~cm}$ registrou-se menos de $4 \%$ das raízes, independente do sistema de manejo do solo.

O excesso hídrico durante parte do desenvolvimento vegetativo pode, também, para esta cultura, ter estimulado o desenvolvimento superficial das raízes. Stanley et al. (1980) relataram que a imposição de saturação de água no solo antes da floração, paralisou o crescimento das raízes da soja. Em contraste, considerando que a densidade inicial do solo 
era de cerca de $1,3 \mathrm{~g} / \mathrm{cm}^{3}$, Moraes et al. (1995) relataram que o crescimento das raízes desta leguminosa ficou praticamente impedido a partir da densidade de 1,30 e 1,23 g/ $\mathrm{cm}^{3}$ em Terra Roxa Estruturada e Latossolo Roxo, respectivamente, compativel também com os resultados obtidos por Torres \& Saraiva (1997). Alguns resultados da literatura mostram que no sistema de plantio direto ocorre a maior concentração de raízes na superfície do solo (Cardoso, 1993; Jaster et al., 1993; Torres \& Saraiva, 1995a,b; Torres et al., 1995a;) e melhor distribuição no perfil quando o solo é revolvido com aração ou escarificação (Veiga \& Oliveira, 1976; Maia \& Eltz, 1992; Cardoso, 1993; Jaster et al., 1993; Torres \& Saraiva, 1995a; Torres et al., 1995a).

Para o feijoeiro, a concentração superficial das raízes também prevaleceu, registrando-se mais de $66 \%$ nos primeiros $10 \mathrm{~cm}$ de profundidade e $89 \%$ no perfil $0-20 \mathrm{~cm}$ (Apêndices 22 e 26), o que coincide concordando com os resultados discutidos por Inforzato (1963); Oliveira \& Silva (1990); Pires et al. (1991); Teixeira et al. (1992); Stone \& Pereira (1994b) e Stone \& Silveira (1996).

A matéria seca das raízes revelou a mesma tendência (Apêndice 23). Para o feijoeiro, entretanto, observou-se efeito do manejo do solo sobre o volume médio de raízes. O preparo do solo com aração resultou no maior volume de raízes, seguido da escarificação, plantio direto e grade aradora, corroborando os resultados obtidos por Stone \& Silveira (1996).

A melhor distribuição de raízes desta leguminosa no perfil do solo foi verificada no manejo com aivecas, seguido da escarificação, demonstrando ter havido impedimento físico no perfil. Tu \& Tan (1991) concluíram que o impedimento físico é o principal fator que determina 0 alongamento e proliferação das raízes do feijoeiro. No presente estudo, o 
menor volume radicular foi observado no preparo do solo com grade aradora e a maior concentração superficial, no plantio direto. Abaixo de $40 \mathrm{~cm}$ de profundidade registrou-se menos de $4 \%$ do volume radicular, estando de acordo com Rovira (1975), que observou que a profundidade máxima atingida pelo feijoeiro foi de $50 \mathrm{~cm}$, tendo como zona dinâmica de absorção os primeiros $10 \mathrm{~cm}$ de profundidade.

Para o arroz de terras altas não houve diferença significativa no volume médio de raízes nos diferentes manejos (Apêndices 22 e 23). Entretanto, tendência a maiores volumes e melhor distribuição no perfil foi observada nos manejos do solo com aração e escarificação, em relação a grade aradora ou o plantio direto. Melhor desenvolvimento radicular do arroz em solos descompactados foi também registrada por Bouzinac et al. (1987), Kluthcouski et al. (1991) e Guimarães (1997).

Stone \& Moreira (1998), no entanto, observaram considerável distribuição de raízes do arroz no sistema de plantio direto, superior ao preparo com grade aradora, na qual a maior concentração ocorreu nos primeiros $10 \mathrm{~cm}$ de profundidade. Guimarães \& Moreira (1997) registraram redução no desenvolvimento radicular do arroz a partir da densidade de 1,2 $\mathrm{g} / \mathrm{cm}^{3}$, e em condições controladas, Grohmann \& Queiroz Neto (1966) fizeram idêntica observação quando o solo apresentava densidade de 1,42 $\mathrm{g} / \mathrm{cm}^{3}$ em Latossolo Roxo e 1,38 $\mathrm{g} / \mathrm{cm}^{3}$ em Podzolico Vermelho Amarelo.

Neste estudo, mais de $60 \%$ e $89 \%$ das raízes do arroz ficaram distribuídos nos primeiros $10 \mathrm{~cm}$ e $20 \mathrm{~cm}$ de profundidade, respectivamente, estando em consonância com as observações feitas por Stone \& Pereira (1994a) e Stone \& Moreira (1998). Abaixo de $60 \mathrm{~cm}$, verificou-se apenas cerca de $3 \%$ do volume radicular, independente do manejo do solo. 


\subsection{Manejo do solo e rendimento das culturas}

O rendimento médio do milho foi relativamente baixo em função das condições climáticas do ano agrícola, o que possivelmente, prejudicou a manifestação da cultura aos tratamentos aplicados. Tanto o excesso de chuvas, com conseqüente redução na luminosidade, como o intenso ataque de Phaeosphaeria maydis, a partir do pendoamento, podem ter afetado negativamente a cultura. Ainda assim, coube observar que 0 rendimento de grãos foi significativamente superior na aração em relação aos demais manejos (Tabela 26).

Tal comportamento sugere que a cultura apresentou relativa sensibilidade à compactação do solo ou um possível efeito negativo decorrente da cobertura morta. Tendências semelhantes foram registradas também por Steinhardt (1983), Oliveira et al. (1988b); Fancelli \& Favarin (1989a); Oliveira et al. (1989); Balbino et al. (1994) e Machado (199_).

Os componentes da produção que mais contribuíram à determinação da produção foram o número de fileiras por espiga e o número de grãos por fileira. O número médio de fileiras por espiga no manejo com aração não diferiu do que foi registrado no manejo com escarificação, mas foi superior aos dos manejos com grade aradora e plantio direto. Já o plantio direto, isoladamente, apresentou o menor número de grãos por fileira. A produção de matéria seca foi superior nos manejos que descompactaram o solo, enquanto a altura média de inserção das espigas foi superior apenas no manejo com arado de aivecas. 


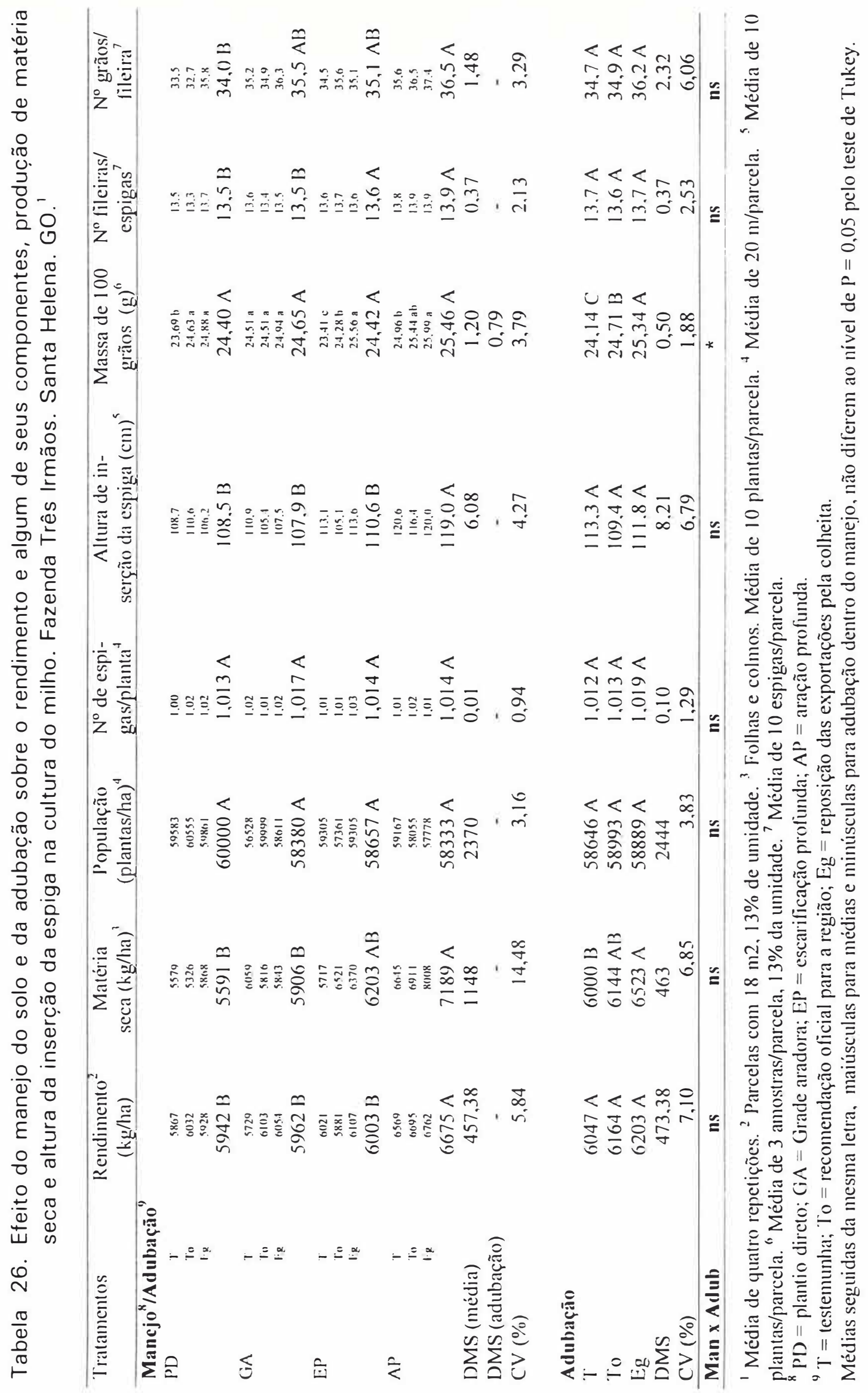


Os níveis de adubação potássica e fosfatada afetaram significativamente a produção de matéria seca. A massa de 100 grãos, aumentou com a elevação da adubação. Observou-se, também, efeito significativo da interação entre manejo e adubação na massa de 100 grãos, a qual aumentou com a elevação da adubação, sendo inferior apenas na escarificação sem complemento de adubação fosfatada e potássica (Apêndice 27).

Pottker (1997), não verificou resposta do milho, em solo com $43 \%$ de argila e sob plantio direto, à adubação fosfatada quando o teor de $P$ excedeu a $13,6 \mathrm{mg} / \mathrm{dm}^{3}$, concluindo ser possível realizar vários cultivos sem adição deste nutriente. Em outro solo, com maior teor de argila (63\%) e P em torno de $4,3 \mathrm{mg} / \mathrm{dm}^{3}$, houve resposta apenas ao incremento da matéria seca. Raij et al. (1981), concluíram não haver resposta do milho à adubação fosfatada em solos cujo teor deste nutriente encontra-se igual ou acima de 14 ppm. Em geral, a cultura respondeu à adubação fosfatada em solos com teor de $P$ inferior a $16 \mathrm{ppm}$. Para o K, estes autores verificaram relação positiva desta cultura apenas quando o solo apresentou menos de 0,10 meq/100 g de K. Muzilli et al. (1989), também verificaram que no Estado do Paraná, a cultura do milho respondeu à adubação fosfatada quando o teor de $P$ no solo foi inferior a 16 ppm, acima do qual o $P$ é classificado como muito alto.

Mallarino (1997), verificou que no cultivo do milho, em 26 condições distintas de solo, houve resposta à adubação fosfatada em apenas seis locais, onde o $P$ no solo foi classificado como deficiente ou muito deficiente.

Nestes estudos, os rendimentos máximos da cultura foram obtidos com a adição de $30 \mathrm{~kg} / \mathrm{ha}$ de $\mathrm{P}_{2} \mathrm{O}_{5}$, ainda que o $\mathrm{P}$ no solo fosse 
classificado como muito deficiente. Da mesma forma, Sá (1997), não observou resposta desta cultura a doses superiores a $30 \mathrm{~kg} / \mathrm{ha}$ de $\mathrm{P}_{2} \mathrm{O}_{5}$, em solo com teor de $\mathrm{P}$ da ordem de $10 \mathrm{ppm}$, no perfil $0-10 \mathrm{~cm}$. Este autor concluiu que o $\mathrm{P}$ é o nutriente que permite maior economia no plantio direto. Bordoli \& Mallarino (1998), só verificaram resposta do milho à adubação fosfatada em solos com menos de $17 \mathrm{ppm}$ de $P$, extraido pelo método Bray I.

A escarificação resultou em ligeiro acréscimo no rendimento de grãos em relação à grade aradora e ao plantio direto, tendo sido reportada como o melhor método de manejo do solo para a cultura por Edwards et al. (1988), Gill et al. (1996) e Uhde et al. (1996). Já a grade aradora foi citada como o pior dos métodos por Oliveira et al. (1989) e Balbino et al. (1994). Alguns autores, no entanto, encontraram no plantio direto o melhor rendimento do milho, a exemplo de Hernani (1997).

A massa de 100 grãos foi significativamente afetada pela interação entre manejo e adubação (Apêndice 27). Maiores valores corresponderam aos maiores níveis de adubação fosfatada e potássica e, apesar da aração com aivecas ter resultado na maior massa de 100 grãos, houve efeito significativo apenas na ausência de adubação.

A soja tem sido, dentre as principais culturas, a mais adaptada ao cerrado brasileiro e demonstrou ser a espécie mais adaptada também ao sistema de plantio direto, independente das possíveis restrições de adensamento do solo ou concentração superficial de nutrientes. Não houve efeito dos diferentes manejos de solo sobre o rendimento de grãos, número de vagem por planta e massa de 100 grãos (Tabela 27). 


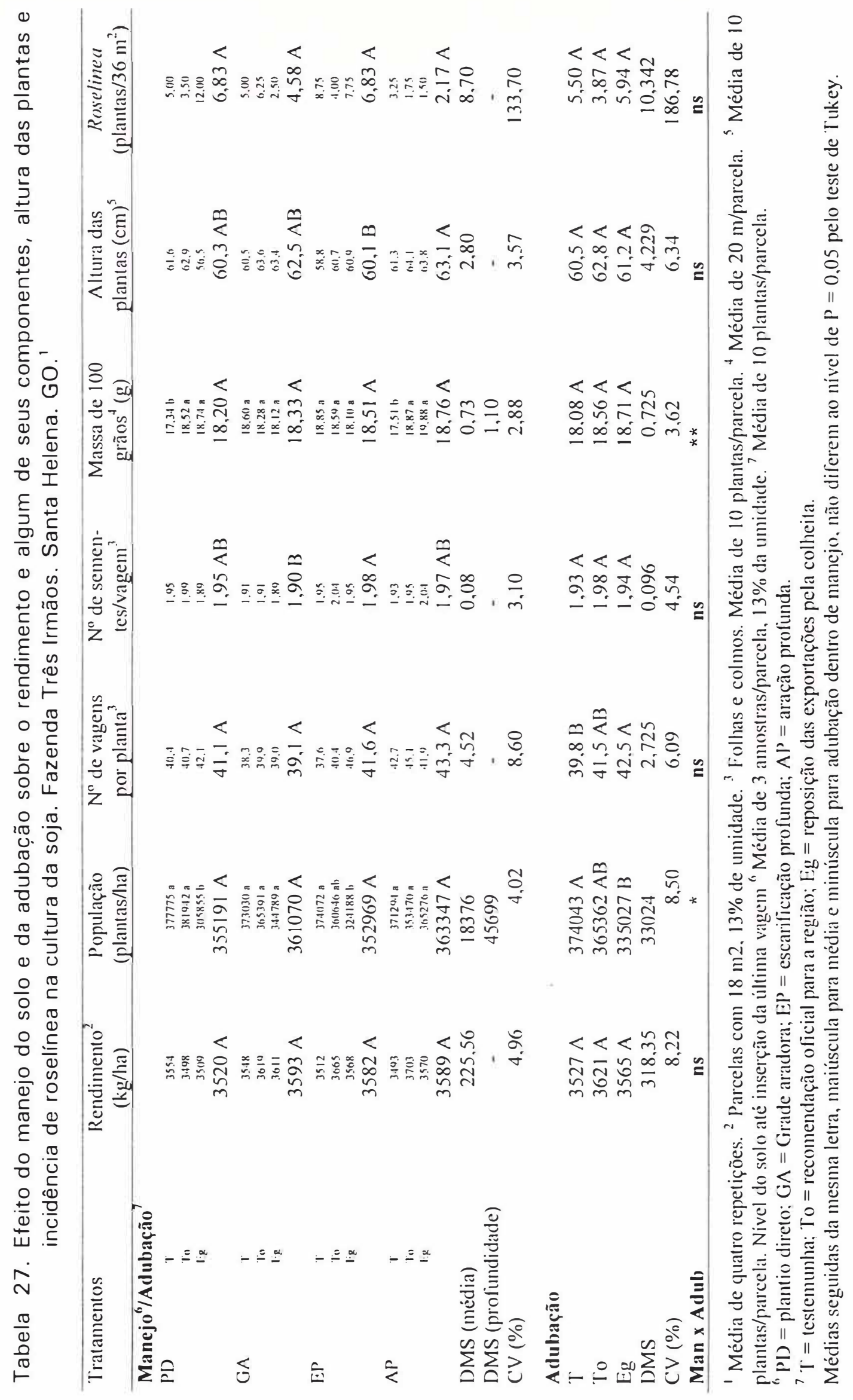


ppm. A partir de 13,6 ppm, nenhuma resposta foi verificada. Mallarino (1997), em 26 locais avaliados, observou resposta da soja à adubação fosfatada em quatro, nos quais o $\mathrm{P}$ no solo foi classificado como muito baixo, entre 0 e 8 ppm, permitindo a este autor recomendar que, em solos com alto teor de $P$, deve-se aplicar somente o equivalente à exportação pela colheita. Neste mesmo estudo, este autor verificou resposta da soja à adubação potássica em três dos 15 locais avaliados, assim mesmo na dosagem máxima de $35 \mathrm{~kg} /$ ha de $\mathrm{K}_{2} \mathrm{O}$.

Os dados referentes à interação entre manejo e adubação sobre a massa de 100 grãos, apesar da relativa inconsistência, indicam redução deste na ausência de adubação, bem como nos altos níveis de adubação potássica (Apêndice 29).

Para o feijoeiro, observou-se efeito significativo do manejo do solo com a aração sobre todos os demais manejos, nos valores médios de rendimento de grãos (Tabela 28), estando em consonância com os resultados obtidos por Mullins \& Straw (1988). Este resultado difere, no entanto, dos alcançados por Silveira \& Silva (1996), Urchei (1996) e Stone \& Silveira (1996), os quais observaram ligeira superioridade do plantio direto sobre o manejo convencional do solo no rendimento de grãos desta leguminosa, principalmente sob irrigação, no período de inverno.

Nenhum dos componentes da produção, entretanto, foi afetado pelo manejo do solo, sendo a diferença no rendimento de grãos melhor explicada pela variação na população final de plantas, que não foi afetada significativamente pelo manejo. O rendimento de grãos foi também superior no nível mais alto de adubação potássica, sendo reflexo do maior número de vagens por planta. Em média para os manejos, e igualmente à cultura da soja, o aumento na adubação potássica resultou em acentuado decréscimo na população final de plantas, reflexo da salinização. É possível que este 


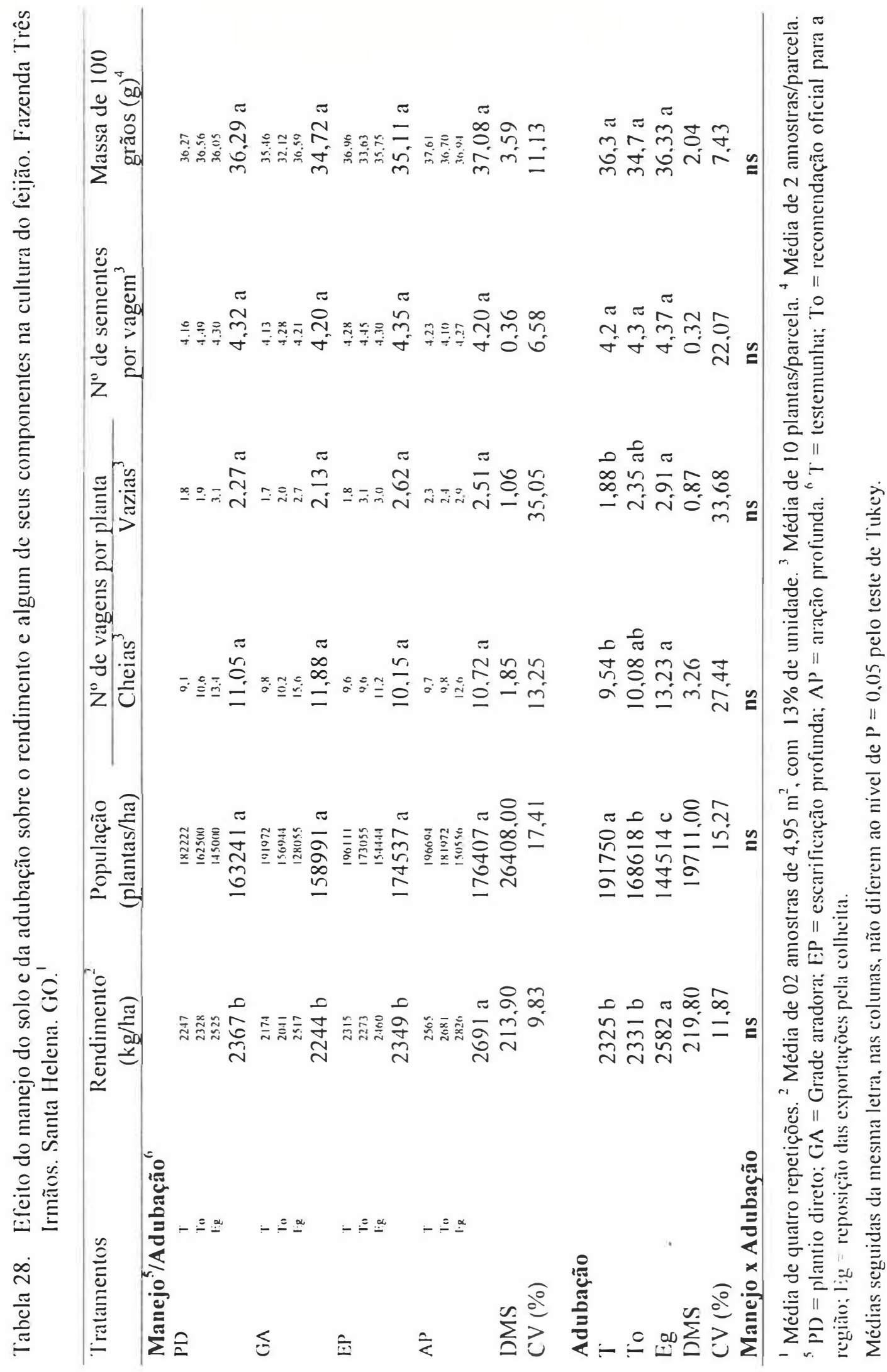


resultado seja a razão do efeito significativo no rendimento de grãos, ainda que a análise de covariância não tenha comprovado ao nível de $P=0,05$ pelo teste de Tukey.

O único componente da produção afetado pelo manejo do solo foi o número de sementes por vagem, que se apresentou inferior apenas no manejo com grade aradora. A maior parte dos trabalhos desenvolvidos com esta cultura mostra tendência semelhante, inclusive com pequena vantagem do plantio direto no rendimento de grãos (Ramos \& Dedecek, 1979; Sidiras et al., 1983; Torres et al., 1988; Oliveira et al., 1989 e Balbino \& Oliveira, 1992). A altura das plantas foi reduzida no manejo com escarificação, sem que isso tenha implicado em conseqüência para o rendimento de grãos.

Os níveis de adubação, da mesma forma, não afetaram o rendimento de grãos e a maioria dos seus componentes e ainda a altura das plantas, aumentando apenas o número de vagens por planta. O aumento da adubação potássica, no entanto, provocou redução na população final das plantas, provavelmente pelo efeito salino do fertilizante. Esta observação foi mais expressiva no plantio direto e escarificação, possivelmente devido à menor mobilidade do nutriente no solo, resultante do maior adensamento do solo próximo à posição do adubo e da semente (Apêndice 28).

Kochhann \& Denardin (1997), não verificaram resposta da cultura da soja à dose superior a $20 \mathrm{~kg} / \mathrm{ha}$ de $\mathrm{P}_{2} \mathrm{O}_{5}$ no sistema de plantio direto, enquanto Pottker (1997), também no sistema de plantio direto, observou resposta desta cultura à adubação fosfatada apenas quando o $P$ no solo foi igual ou inferior a 4,3 .

Dentre as quatro culturas avaliadas, o arroz de terras altas mostrou-se o menos adaptado às condições de solo sob plantio direto. 0 rendimento de grãos e seus componentes, exceto a massa de 100 grãos, 
foram afetados negativamente pelas propriedades do solo inerentes ao plantio direto (Tabela 29). A vantagem atribuída ao revolvimento do solo, com qualquer implemento, em relação ao plantio direto, foi de até $46 \%$ no rendimento de grãos. Estes dados assemelham-se aos registrados por Stone et al. (1980) e Seguy \& Bouzinac (1992).

Já que o rendimento de grãos foi superior nos solos movimentados, principalmente nos manejos que romperam a camada adensada (aração e escarificação), o arroz demonstra ser altamente sensível às condições de porosidade do solo, confirmando as observações de Seguy et al. (1989) de que esta gramínea é bastante sensível à condição de baixa macroporosidade no solo, independente das condições hídricas do ano agrícola. No plantio direto observou-se também maior esterilidade das espiguetas, podendo ser reflexo da má alimentação hídrica ou mineral, em função, provavelmente, de distúrbios no enraizamento ou na absorção de nutrientes devidos à compactação. A altura das plantas e a área foliar e ainda a produção de matéria seca foram também inferiores no sistema de plantio direto.

Os níveis de adubação, no entanto, não afetaram nenhum dos parâmetros avaliados, havendo apenas tendência a maiores rendimentos nos níveis mais altos de adubação potássica e fosfatada. O arroz de terras altas, no cerrado, tem mostrado elevada adaptação aos solos de baixa fertilidade e ácidos de acordo com Kluthcouski et al. (1991, 1995).

Fageria et al. (1988), avaliaram 25 cultivares de arroz em solos com teor de $P$ de 1,5 e $5,0 \mathrm{mg} / \mathrm{kg}$ e observaram, para a maioria delas, que houve pouca diferença no rendimento de grãos entre as duas situações. Estes autores relataram ainda que o arroz de terras altas tem respondido menos à adubação potássica que o irrigado. Em outro estudo, Fageria etl al. 


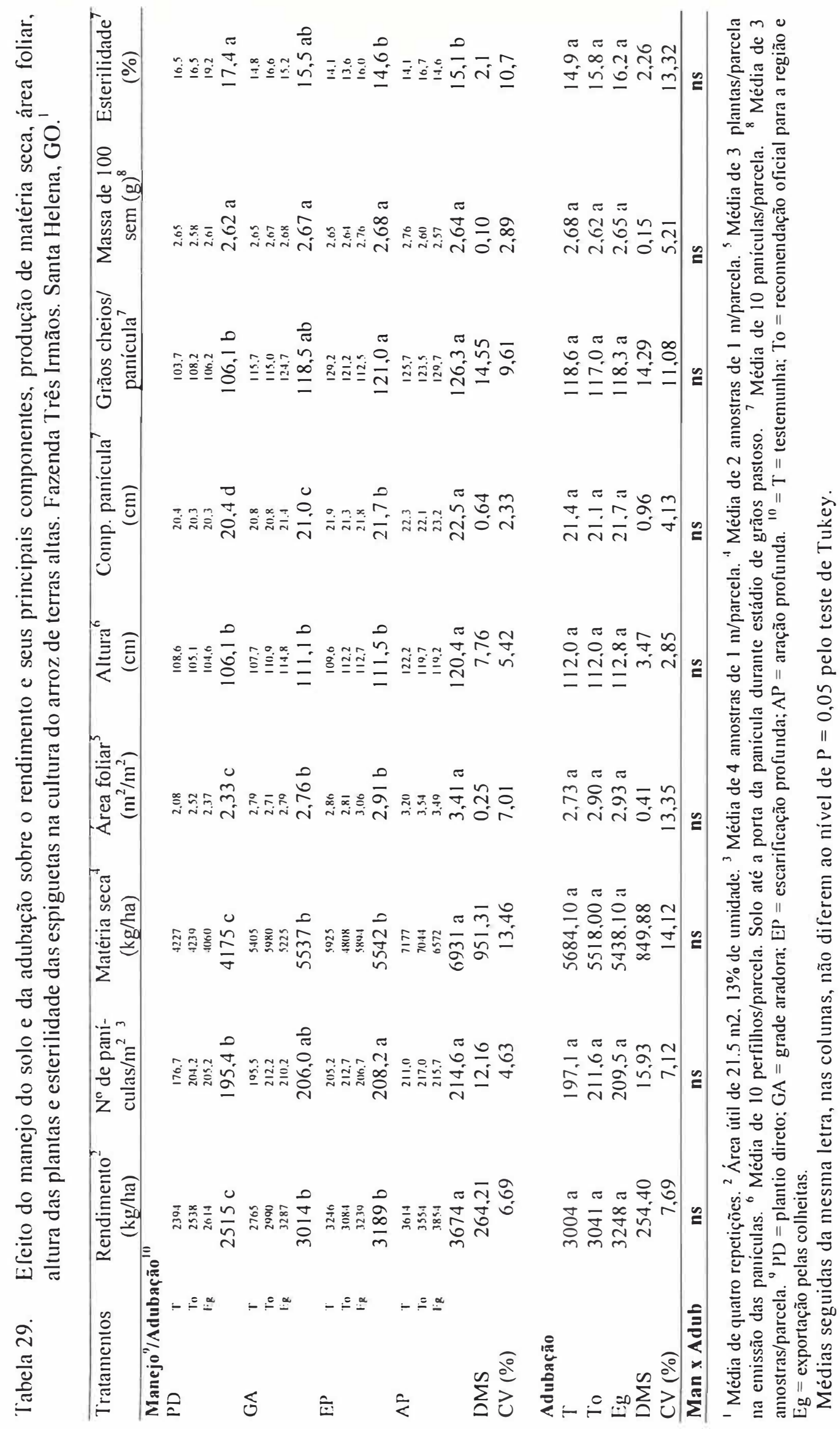


(1995), avaliando 19 cultivares de arroz de terras altas de ciclo médio e 10 de ciclo curto, em solo com 2,2 e $61 \mathrm{mg} / \mathrm{kg}$ de $\mathrm{P}$ e $\mathrm{K}$, respectivamente, verificaram que os cultivares precoces responderam à aplicação de até 60 $\mathrm{kg} / \mathrm{ha}$ de $\mathrm{P}_{2} \mathrm{O}_{5}$, enquanto os de ciclo médio, em geral, além de não responderem, sofreram, em alguns casos, ligeiro decréscimo de rendimento no nível mais alto de $\mathrm{P}_{2} \mathrm{O}_{5}, 60 \mathrm{~kg} / \mathrm{ha}$. Estes autores concluíram que existem diferenças significativas entre genótipos de arroz quando a resposta a um determinado nível de $\mathrm{P}$ no solo.

\subsection{Conversão de unidades}

As unidades usada nesta tese podem ser convertidas em outras, tendo em conta as relações que se seguem.

\begin{tabular}{cccc}
\hline $\begin{array}{c}\text { Para converter a } \\
\text { coluna 1 para coluna } \\
\text { 2, multiplicar por }\end{array}$ & Coluna & Coluna 2 & $\begin{array}{c}\text { Para converter a } \\
\text { coluna 2 em coluna } \\
\text { 1, multiplicar por }\end{array}$ \\
\hline 1 & $\mathrm{cmol}^{\mathrm{c}} \mathrm{kg}^{-1}$ & $\mathrm{meq} 100 \mathrm{~g}^{-1}$ & 1 \\
0.1 & $\mathrm{~g} \mathrm{~kg}^{-1}$ & $\%$ & 10 \\
0.1 & ${\mathrm{~g} / \mathrm{dm}^{-3}}^{-1}$ & $\%$ & 10 \\
0.1 & $\mathrm{~g} \mathrm{~L}^{-1}$ & $\%$ & 10 \\
1 & $\mathrm{mg} \mathrm{kg}^{-1}$ & $\mathrm{ppm}$ & 1 \\
1 & $\mathrm{mg} \mathrm{dm}^{-3}$ & $\mathrm{ppm}$ & 1 \\
1 & $\mathrm{mg} \mathrm{L}^{-1}$ & $\mathrm{ppm}$ & 1 \\
10 & $\mathrm{~S} \mathrm{~m}^{-1}$ & mmho cm & 0.1 \\
2.29 & $\mathrm{P}$ & $\mathrm{P} \mathrm{O}_{5}$ & 0,437 \\
1.20 & $\mathrm{~K}$ & $\mathrm{~K}{ }_{2} \mathrm{O}$ & 0,830 \\
9.90 & $\mathrm{MPa}$ & Atm & 0.101 \\
10 & $\mathrm{MPa}$ & bar & 0.1 \\
$\left(9 / 5^{\circ} \mathrm{C}\right)+32$ & ${ }^{\circ} \mathrm{C}$ & ${ }^{\circ} \mathrm{F}$ & $5 / 9\left({ }^{\circ} \mathrm{F}-32\right)$ \\
2.42 & $\mathrm{Ha}$ & Alqueire (paulista) & 0.413 \\
4.84 & $\mathrm{Ha}$ & Alqueire (goiano) & 0.206 \\
2.47 & $\mathrm{Ha}$ & Acre & 0.405 \\
\hline
\end{tabular}




\subsection{Considerações finais}

Com este estudo foi possivel aferir algumas conclusões, como mostra o item seis. Contudo, muitas das observações registradas, apesar de exponenciais, ainda carecem de maiores e melhores explicações, sugerindo a necessidade de mais pesquisas. Nesta relação destaca-se:

4.11.1. A amostragem do solo, tanto para análise física como química, em áreas com sucessivos cultivos no sistema de plantio direto, necessita ser reestudada no sentido de se estabelecer critérios de subamostras e técnica de amostragem adequados para o sistema;

4.11.2. Mesmo com o uso intensivo da área, obtendo-se até três colheitas por ano agrícola, a produção de resíduos culturais para cobertura morta, observada nos experimentos e nas áreas de produção da propriedade, não tem sido suficiente para a proteção adequada da superfície do solo, sugerindo a necessidade de cultivos cíclicos de espécies exclusivas para cobertura do solo;

4.11.3. A despeito dos benefícios da microbiologia em todas as propriedades do solo, e considerando a potencialização de suas populações e atividade no sistema de plantio direto, principalmente em regiões tropicais, existe a necessidade premente de estudos sobre o seu comportamento, visto a possibilidade de redução acentuada, tanto na população final, como no potencial produtivo das plantas cultivadas devida a fungos patogênicos. 
4.11.4. Tanto a quantidade e balanceamento dos nutrientes, como os métodos de aplicação de alguns fertilizantes têm que ser revistos no sistema de plantio direto, principalmente quando se atingem níveis altos de nutrientes no solo, ou mesmo quando a movimentação destes é dificultada em razão de adensamento/redução da macroporosidade, ou ainda, devido à retenção pela matéria orgânica. Estudo paralelo conduzido a partir de julho de 1997, mostra que a salinização provocada por alguns fertilizantes, no caso N-P-K, pode reduzir o rendimento do feijoeiro. Em c sntrapartida, a adubação mais profunda pode elevar o rendimento da cultura (Apêndice 30);

4.11.5. Considerando que a maior parte dos estudos sobre o a ranjo espacial das plantas foi realizada em solos não corrigidos adequadamente, utilizando o sistema convencional de manejo do solo, existe a necessidade de reestudo deste particular no sistema de plantio direto, conjugado à alta fertilidade do solo. Em outro estudo conduzido paralelamente, observou-se que, ao contrário do que se esperava, as plantas de feijão não compensaram o maior espaço devido à redução na população (.Apêndice 31). Com outras culturas com ciclo geralmente maior, caso da soja e do milho, o inverso pode ocorrer; e

4.11.6. As grandes amplitudes, registradas na literatura, entre valores que determinam como adequadas as concentrações foliares de alguns nutrientes, não possibilitam interpretação segura sobre o estado riutricional das plantas. 


\section{CONCLUSÕES}

Nas condições que o estudo foi conduzido, considerando principalmente as variações na pluviosidade e altos teores de nutrientes no solo, os resultados obtidos permitem as seguintes conclusões:

5.1. Desconsiderando o sistema de manejo empregado antes da implantação do sistema de plantio direto, o cultivo da área durante o período de oito anos neste sistema, resultou em ligeiro adensamento da camada subsuperficial do solo com conseqüente redução da macroporosidade e porosidade total, provocando restrições significativas no aprofundamento radicular das culturas do milho e do feijão, e não significativa para a soja e o arroz;

5.2. O acúmulo superficial de nutrientes em áreas com sucessivos cultivos sob plantio direto não teve efeito significativo sobre 0 comportamento das culturas, havendo homogeneização no perfil, daqueles que mais se concentraram na superfície, devido ao revolvimento do solo através da aração. 
5.3. Nas adubações de manutenção, no sulco de plantio, a concentração excessiva de fertilizantes muito salinos, tal como o cloreto de potássio, prejudica a população final de plantas, principalmente de leguminosas, indicando a necessidade de alteração no método de fertilização;

5.4. O revolvimento do solo reduz apenas temporariamente a população de fungos patogênicos do solo, alterando grandemente a atividade microbiológica;

5.5. Considerando que as culturas não concentraram teores supérfluos de nutrientes nas folhas, as variações encontradas na distribuição dos nutrientes no solo não foram refletidas na concentração foliar dos mesmos.

5.6. A quase generalizada ausência de resposta das culturas à adubação indica que, a partir de certa concentração de nutrientes no solo, há necessidade de mudança nas quantidades de nutrientes e serem aplicadas para manutenção da fertilidade do solo e obtenção de altos rendimentos;

5.7. As culturas da soja e do feijão apresentaram melhor adaptabilidade ao sistema de plantio direto do que o milho e, principalmente, do que o arroz de terras altas; 
5.8. A pouca adaptação do arroz de terras altas ao sistema de plantio direto é, basicamente, devida ao adensamento do solo e redução na macroporosidade;

5.9. Desde que haja constante monitoramento de problemas de segunda geração tais como a salinização, formação e manutenção da cobertura morta, proliferação excessiva de microrganismos patogênicos, adensamento excessivo, dentre outros, o sistema de plantio direto, em regiões tropicais, aparece como sistema altamente vantajoso, para as culturas da soja e do feijão e intermediário para o milho e arroz de terras altas;

5.10. Os resultados obtidos não permitem concluir, principalmente devido ao excesso hídrico, sobre a necessidade de revolvimento cíclico do solo, exceto para a cultura do arroz de terras altas, podendo esta ser preferencial no sistema de rotação, caso o revolvimento do solo, por alguma razão, seja indispensável. 


\section{REFERÊNCIAS BIBLIOGRÁFICAS}

ALbuqueroue, J.A.; ReINERT, D.J.; FIORON, J.E. et al. Rotação de culturas e sistemas de manejo do solo ao final de sete anos. Revista Brasileira de Ciência do Solo, Campinas, v.19, n.1, p.115-119, 1995.

ALONÇO, A. dos S.; FERREIRA, O.O. Incorporação profunda de fertilizantes e calcário: sua influência na produção de milho (Zea mays L.) sob stress hídrico e sobre algumas propriedades físicas e químicas de um solo cerrado. In: CONGRESSO BRASILEIRO DE ENGENHARIA AGRíCOLA, 20., 1991, Londrina, PR. Anais. Londrina: SBEA, 1992. p.1206-1225.

ALVARENGA, R.C.; COSTA, L.M. da.; MOURA FILHO, V. et al. Crescimento e absorção de nutrientes por leguminosas em resposta à compactação do solo. In: CONCRESSO BRASILEIRO DE CIÊNCIA DO SOLO, 25., 1995, Vic̣osa, MG. Resumos expandidos. Viçosa : SBCS, 1995. p.1951-1952.

ANDERSON, E.L. Corn root growth and distribution as influenced by tillage and nitrogen fertilization. Agronomy Journal, Madison, v.79, n.3, p.544$549,1987$. 
ASSAD, E.D. Análise do risco climático do plantio à colheita. In: LANDERS, J.N. (Ed.). Fascículo de experiências de plantio direto no cerrado. Goiânia : APDC, 1995. p.169-183.

AZEVEDO, C.S.S.; ANTUNES, I.F.; SANTOS FILHO, B.G. Peso da matéria seca da parte aérea e do sistema radicular mais as raízes adventícias na caracterização de dois cultivares de feijão submetidas a excesso de umidade no solo: In: REUNIÃO NACIONAL DE PESQUISA DE FEIJÃO, 4., 1993, Londrina, PR. Resumos. Londrina : IAPAR, 1993. p.17.

AZEVEDO, J.A. de.; SILVA, E.M. de; RESENDE, M. Aspectos sobre o manejo da irrigação por aspersão para o cerrado. Planaltina : EMBRAPACPAC, 1983. 53p. (EMBRAPA-CPAC. Circular Técnica, 16).

BALBINO, L.C. MOREIRA, J.A.A.; SILVA, J.G. da et al. Plantio direto. In: ARAUJO, R.S.; RAVA, C.A.; STONE, L.F.; ZIMMERMANN, M.J. de O. (Coord.). Cultura do feijoeiro comum no Brasil. Piracicaba : POTAFOS, 1996. p.301-352.

BALBINO, L.C. Sistema plantio direto. In: REUNIÃO NACIONAL DE PESQUISA DE FEIJÃO, 5., 1996, Goiânia, GO. Anais. Goiânia : EMBRAPA-CNPAF, 1997. v.2. p.219-228. (EMBRAPA-CNPAF. Documentos, 70). 
BALBINO, L.C.; OLIVEIRA, E.F. do. Efeito de sistemas de preparo do solo no rendimento de grãos de trigo, soja e milho. In: CONGRESSO BRASILEIRO DE ENGENHARIA AGRÍCOLA, 20., 1991, Londrina, PR. Anais. Londrina : SBEA, 1992. p.1354-1360.

BALBINO, L.C.; OLIVEIRA, E.F.; RALISCH, R. et al. Desenvolvimento do milho (Zea mays L.) submetido a três sistemas de manejo em um Latossolo Roxo eutrófico. In: CONGRESSO NACIONAL DE MILHO E SORGO, 20., 1994, Goiânia, GO. Resumos. Goiânia : ABMS, 1994. p.221.

BARBER, S.A. Fertilizer rate and placement effects on nutrient uptake by soybeans. In: WORD SOYBEAN RESEARCH CONFERENCE, 3., 1984, Ames. Proceedings. Boulder: Westview, 1985. p.1007-1115.

BARBER, S.A.; OLSON, R.A. Fertilizer use on corn. In: NELSON, L.B. Changing patterns in fertilizer use. Madison: SSSA, 1968. p.163-188.

BATAGLIA, O.C.; RAIJ. B. Van. Eficiência de extratores na determinação de boro em solos. Revista Brasileira de Ciência do Solo, Campinas, v.14, n.1, p.21-31, 1990.

BAYER, C.; MIELNICZUK, J.; PAVINATO, A. Sistemas de manejo do solo e seus efeitos sobre o rendimento do milho. Ciência Rural, Santa Maria, v.18, n.1, p.23-28, 1988. 
BENEZ, S.H.; GAMERO, C.A.; FURLANI JR., J.A. Efeitos da compactação do solo no desenvolvimento do sistema radicular da soja (Glycine max L. Merril). In: CONGRESSO BRASILEIRO DE ENGENHARIA AGRÍCOLA, 15., 1986, São Paulo, SP. Anais. São Paulo: SBEA, 1986. p.310.

BERNI, R.F.; MOREIRA, J.A.A.; RIOS, G.P. et al. Influência dos níveis de água de irrigação e preparo de solo nas podridões radiculares do feijoeiro. Fitopatologia Brasileira, Brasília, v.22 (suplemento) p.250, 1997.

BORDOLI, J.M.; MALLARINO, A.P. Deep and shallow banding of phosphorus and potassium as alternating to broadcast fertilization for no-till corn. Agronomy Journal, Madison, v.90, n.1, p.27-33, 1998.

BORGES, E.N.; NOVAIS, R.F. de; REGAZZI, A.J. et al. Resposta de variedades de soja à compactação de camadas do solo. Revista Ceres, Viçosa, v. 35, n. 202, p.553-568, 1988.

BOUZINAC, S.R.R.; SEGUY, L.; KLUTHCOUSKI, J. Efeito de métodos de preparo do solo sobre o enraizamento do arroz de sequeiro. In: REUNIÃO NACIONAL DE PESQUISA DO ARROZ, 3., 1987, Goiânia, GO. Resumos. Goiânia : EMBRAPA-CNPAF, 1987. p.120. (EMBRAPA-CNPAF. Documentos, 19).

BÜLL, L.T. Nutrição mineral do milho. In: BÜLL, L.T.; CANTARELLA, H. (Ed.). Cultura do milho: fatores que afetam a produtividade. Piracicaba : POTAFOS, 1993. p.63-145. 
CAMPOS, B.C. de.; REINERT, D.J.; NICOLODI, R. et al. Estabilidade estrutural de um Latossolo Vermelho escuro distrófico após sete anos de rotação de culturas e sistemas de manejo do solo. Revista Brasileira de Ciência do Solo, Campinas, v.19, n.1, p.121-126, 1995.

CANALLI, L.B.; ROLOFF, G. Influência do preparo e da correção do solo na condição hídrica de um Latossolo Vermelho escuro sob plantio direto. Revista Brasileira de Ciência do Solo, Campinas, v.21, n.1, p.99-104, 1997.

CARDOSO, A.N. Manejo e conservação do solo na cultura da soja. In: SIMPÓSIO SOBRE A CULTURA DA SOJA NO CERRADO, 1992, Uberaba, MG. Cultura da soja nos cerrados: anais. Piracicaba : POTAFOS, 1993. p.71-104.

CARDOSO, J.E.; RAVA, C.A.; SARTORATO, A. Doenças causadas por fungos do solo. In: ARAUJO, R.S.; RAVA, C.A.; STONE, L.F.; ZIMMERMANN, M.J. de O. (Coord.). Cultura do feijoeiro comum no Brasil. Piracicaba : POTAFOS, 1996. p.701-722.

CARMO, D.A.S. Algumas considerações sobre agricultura irrigada na região dos cerrados. In: SIMPOSIO SOBRE O CERRADO, 7., 1989, Brasília, DF. Estratégias de utilização: anais. 2.ed. Planaltina : EMBRAPA-CPAC, 1997. p.87-97. 
CARPENEDO, V.; MIELNICZUK, J. Estado de agregação e qualidade de agregados de Latossolos roxos, submetidos a diferentes sistemas de manejo. Revista Brasileira de Ciência do Solo, Campinas, v.14, n.1, p.99-105, 1990.

CASTRO, O.M. de. Compactação do solo em plantio direto. In: FANCELLI, A.L. (Coord.). Plantio direto no Estado de São Paulo. Assis : FEALQ/ESALQ, 1989. p.129-139.

CASTRO, O.M. de; VIEIRA, S.R.; MARIA, I.C. Sistemas de preparo do solo e disponibilidade de água. In: SIMPÓSIO SOBRE O MANEJO DE ÁGUA NA AGRICULTURA, 1987, Campinas, SP. Anais. Campinas: Fundação Cargill, 1987. p.27-51.

CHAIB, S.L.; BULISANI, E.A.; CASTRO, L.H.S.M. Crescimento e produção do feijoeiro em resposta à profundidade da aplicação do adubo fosfatado. Pesquisa Agropecuária Brasileira, Brasília, v.19, n.7, p.817$822,1984$.

CHOUdhuRY, E.N.; MELLO, C.A. de O.; MORGado, L.B. Preparo do solo e adubação residual na cultura do milho em áreas irrigadas. Petrolina : EMBRAPA-CPATSA, 1991. 21p. (EMBRAPA-CPATSA. Boletim de Pesquisa, 40). 
COBRA NETO, A.; ACCORSI, W.R.; MALAVOLTA, E. Estudos sobre a nutrição mineral do feijoeiro (Phaseolus vulgaris L.; var. roxinho). Anais da Escola Superior de Agricultura Luiz de Queiroz, Piracicaba, v.28, p.257-274, 1971.

COELHO, A.M.; FRANC̣A, G.E. de. Seja doutor do seu milho: nutrição e adubação. Piracicaba : POTAFOS, 1995. 8p. (Arquivo do Agrônomo, 2).

COMISSÃO DE FERTILIDADE DE SOLOS DE GOIÁS. Recomendações de corretivos e fertilizantes para Goiás: $5^{\text {a }}$ aproximação. Goiânia : UFG/EMGOPA, 1988. $101 \mathrm{p}$.

CORDEIRO, D.S.; BORKERT, C.M.; SFREDO, G.J. et al. Efeito de diversos níveis de fósforo de diferentes fontes fosfatadas na concentração de macro e micronutrientes na parte aérea de plantas de soja. In: SEMINÁRIO NACIONAL DE PESOUISA DA SOJA, 1., 1978, Londrina, PR. Anais. Londrina : EMBRAPA-CNPSo, 1979. p.275-281.

CORREA, A.E.; MIYAZAKA, M.; PAVAN, M.A. Método de não digestão para a extração de boro em folhas de plantas. Pesquisa Agropecuária Brasileira, Brasília, v.20, n.10, p.1213-1222, 1985.

CORRÊA, J.C. Efeito de métodos de cultivo em algumas propriedades físicas de um Latossolo amarelo muito argiloso no Estado do Amazonas. Pesquisa Agropecuária Brasileira, Brasília, v.20, p.1317-1322, 1985. 
COSTA, G.R.; COSTA, J.L. da S. Densidade mínima de inóculo de Fusarium solani f. sp. phaseoli para causar podridão radicular seca no feijoeiro. Fitopatologia Brasileira, Brasília, v.22 (suplemento), p.258, 1997.

COSTA, J.A.; MARCHEZAN, E. Características dos estádios de desenvolvimento da soja. Campinas: Fundação Cargill, 1982. 30p.

COSTA, J.L. da S. Inducing suppressiveness to Phytophthora root rot of avocado by using bioenchanced mulches. Riverside : University of California, 1995. 151p. Dissertação (Doutor em Fitopatologia) Universidade da California, Riverside, 1995.

COSTA, J.L. da S. Soil inoculum density limiting the effectiveness of chemicals on the control of white mold on dry beans. In: INTERNATIONAL CONFERENCE ON RESISTENSE 97 - AN INTEGRATED APROACH TO COMBATING RESISTANCE, 1997, Harpenden, U.K. Programs \& papers. Hertz: IACR, 1997a. não paginado.

COSTA, J.L. da S. Situação do mofo branco no feijão de inverno. In: REUNIÃO NACIONAL DE PESQUISA DE FEIJÃO, 5., 1996, Goiânia, Anais. Goiânia : EMBRAPA-CNPAF, 1997b. v.2, p.251-253. (EMBRAPACNPAF. Documentos, 69). 
COSTA, J.L. da C. "Doenças do feijoeiro-comum causadas por fungos de solo: epidemiologia e manejo" e "situação do mofo-branco no feijão de inverno": relatório dos grupos de trabalho. In: REUNIÃO NACIONAL DE PESQUISA DE FEIJÃO. 5., 1996, Goiânia, GO. Anais. Goiânia : EMBRAPA-CNPAF, 1997c. v.2. p.255-263. (EMBRAPA-CNPAF. Documentos, 69).

COSTA, J.L. da S. Conhecendo a microbiologia do seu solo antes de entrar no plantio direto. Direto no Cerrado, Goiânia, v.2, n.6, p.4-5, 1997d.

COSTA, J.L. da S.; SILVEIRA, P.M. da. Influência dos métodos de preparo do solo e rotação de culturas na ocorrência de podridões radiculares do feijoeiro. Fitopatologia Brasileira, Brasília, 22 (suplemento), p.258, 1997.

COSTA, G.R. \& COSTA., J.L. da S. Densidade mínima de inóculo de Fusarium solani. fsp. phaseoli para causar podridão radicular no feijoeiro. Fitopatologia Brasileira, Brasília, 22 (suplemento) p.258, 1997.

COX, F.R. Micronutrient soil tests: correlation and calibration. In: BROWN, J.R. (Ed.). Soil testing: sampling, correlation, calibration and interpretation. Madison: SSSA, 1987. p.97-117.

DENARDIN, J.E.; KOCHHANN, R. A. Requisitos para a implantação e manutenção do sistema plantio direto. In: EMBRAPA. Centro Nacional de Pesquisa de Trigo (Passo Fundo, RS). Plantio direto no Brasil. Passo Fundo: Aldeia Norte, 1993. p.19-27. 
DERPSCH，R. Agricultura sustentável. In: SATURNINO, H.M.; LANDERS, J.N. (Ed.). O meio ambiente e o plantio direto. Brasília : EMBRAPA-SPI, 1997b. p.29-48.

DERPSCH, R. Histórico, requisitos, importância e outras considerações sobre o plantio direto no Brasil. In: TORRADO, P.V.; ALOISI, R.P. (Coord.). Plantio direto no Brasil. Campinas : Fundação Cargill, 1984. p. 1-12.

DERPSCH， R. Importância de la siembra directa para obtener la sustentabilidad de la produccion agricola. In: CONGRESSO NACIONAL DE AAPRESID, 5., 1997, Mar del Plata. Conferências. [S.I. : s.n.], 1997a. p.153-176.

DERPSCH，R.; ROTH， C.H.; SIDIRAS, N. et al. Controle da erosão no Paraná, Brasil: sistemas de cobertura do solo, plantio direto e preparo conservacionista do solo. Eschborn : GTZ, 1991. 272p.

DICK, N.A. Organic carbon, nitrogen, and phosphorus concentrations and $\mathrm{pH}$ in soil profiles as affected by tillage intensity. Soil Science Society of America Journal, Madison, v.47, n.1, p.102-107, 1983.

DURIEUX, R.P.; KAMPRATH, E.J.; JACKSON, W.A. et al. Root distribution of corn: the effect of nitrogen fertilization. Agronomy Journal, Madison, v.86, p.958-962, 1994. 
EDWARDS, J.H.; THURLOW, D.L.; EASON, J.T. Influence of tillage and crop rotation on yield of corn, soybeans and wheat. Agronomy Journal, Madison, v.80, p.76-80, 1988.

EMBRAPA. Centro Nacional de Pesquisa de Arroz e Feijão (Goiânia, GO). Programa de recuperação de pastagens degradadas no cerrado brasileiro: sistema agropastoril auto-sustentável. Goiânia : EMBRAPACNPAF/EMBRAPA-CNPGC, 1995. 26p. (EMBRAPA-CNPAF. Documentos, 59).

EMBRAPA. Centro Nacional de Pesquisa de Solos (Rio de Janeiro, RJ). Manual de métodos de análise de solo. 2.ed. rev. atual. Rio de Janeiro, 1997a. 212p. (EMBRAPA-CNPS. Documentos, 1).

EMBRAPA. Centro de Pesquisas Agropecuárias do Oeste (Dourados, MS). Milho: informações técnicas. Dourados, 1997b. 222p. (EMBRAPACPAO. Circular Técnica, 5).

EMBRAPA. Centro Nacional de Pesquisa da Soja (Londrina, PR). Recomendações técnicas para a cultura da soja na região central do Brasil: 1996/97. Londrina, 1996. 164p. (EMBRAPA-CNPSo. Documentos, 96).

EMBRAPA. Serviço de Produção de Informação (Brasília, DF). Recomendações técnicas para a cultura da soja: região Centro-Oeste. Brasília, 1993. p.9-20. 
EMBRAPA. Centro Nacional de Pesquisa de Arroz e Feijão (Goiânia, GO). Manual de métodos de pesquisa em arroz: primeira aproximação. Goiânia, 1977. 106p.

ESPINOSA, W. Resposta de 12 cultivares de soja ao déficit hídrico num solo LE de cerrado do Distrito Federal. Parte I. Rendimentos, área foliar e desenvolvimento radicular. In: CONGRESSO BRASILEIRO DE ENGENHARIA AgRícolA, 11., 1981, Brasília, DF. Anais. Brasília : Editerra, 1983. p.803-821.

FAGERIA, N.K.; SANTANA, E.P.; MORAIS, O.P. de. Resposta de genótipos de arroz de sequeiro favorecido à fertilidade do solo. Pesquisa Agropecuária Brasileira, Brasília, v.30, n.9. p.1155-1161, 1995.

FAGERIA, N.K. Adubação e nutrição mineral da cultura do arroz. Rio de Janeiro: Campus / Goiânia : EMBRAPA-CNPAF, 1984. 341 p.

FAGERIA, N.K.; BALIGAR, V.C.; JONES, C.A. Growth and mineral nutrition of field crops. 2. ed. New York: Marcel Dekker, 1997. 624p.

FAGERIA, N.K.; MORAIS, O.P.; BALIGAR, V.C. et al. Response of rice cultivars to phosphorus supply on an oxisol. Fertilizer Research, Derdrecht, v.16, p.195-206, 1988. 
FANCELLI, A.L.; FAVARIN, J.L. Realidade e perspectivas para o sistema de plantio direto no Estado de São Paulo. FANCELLI, A.L. (Coord.). Plantio direto no Estado de São Paulo. Assis : FEALQ/ESALQ, 1989a. p.1534.

FANCELLI, A.L. Plantas alimentícias: guia para aula, estudos e discussão. Piracicaba: ESALQ, 1986. 131p.

FANCELLI, A.L.; FAVARIN, J.L. Desempenho da cultura do milho em plantio direto e convencional. In: FANCELLI, A.L. (Coord). Plantio direto no Estado de São Paulo. Assis : FEALQ/ESALQ, 1989b. p.174-175.

FARIAS, J.R.B.; NEUMAIER, N.; NEPOMUCENO, A.L. Impactos de seca na produção de soja. In: REUNIÃO NACIONAL DE PESQUISA DA SOJA NA REGIÃO CENTRAL DO BRASIL, 14., 1992, Campo Grande, MS. Atas. Londrina : EMBRAPA-CNPSO/EMPAER-MS, 1993. p.22. (EMBRAPACNPSo. Documentos, 56).

FERNANDES, B.; GALLOWAY, H.M.; BRONSON, R.D. Efeito de três sistemas de preparo do solo na densidade aparente na porosidade total e na distribuição dos poros em dois solos (Typic Argiaquoll e Typic Hapludalf). Revista Brasileira de Ciência do Solo, Campinas, v.7, n.3, p.329-333, 1983.

FERNANDEZ, F. de C.; GUPTS, P.; LÓPEZ, M. Etapas de desarrollo de la planta del frijol común (Phaseolus vulgaris L.). Cali : CIAT, 1986. 34p. 
FERNANDEZ, F.; ARREGOCES, O. Guia de estúdio: crescimiento y etapas de desarollo de la planta de arroz. Cali : CIAT, 1980. 28p.

FRANZLUEBBERS, S.; HONS, F.M. Soil - profile distribution of primary and secondary plant available nutrients under conventional and no tillage. Soil \& Tillage Research, Amsterdam, v. 39, p.229-239, 1996.

GALLO, R.; MIYASAKA, S. Composição química do feijoeiro e absorção de elementos nutritivos do florescimento à maturação. Bragantia, Campinas, v.20, n.40, p.867-874, 1961.

GASSEN, D.N.; GASSEN, F.R. Plantio direto: o caminho do futuro. Passo Fundo: Aldeia Sul, 1996. 207p.

GENTIL, L.V. Aspectos econômicos do plantio direto. In: SEMINÁRIO INTERNACIONAL DO SISTEMA DE PLANTIO DIRETO, 1., 1995, Passo Fundo, RS. Resumos. Passo Fundo: EMBRAPA-CNPT, 1995. p.9-12.

GILL, K.S.; GAJRI, P.R.; CHOUDHARY, J. et al. Tillage, mulch and irrigation effects on corn (Zea mays L.) in relation to evaporative demand. Soil \& Tillage Research, Amsterdam, v.39, p.213-227, 1996.

GOEDERT, W.J. Uso e manejo dos recursos naturais do cerrado: solo e clima. In: SIMPÓSIO SOBRE O CERRADO, 5., 1979, Brasília, DF. Cerrado: uso e manejo. Brasília : Editerra, 1980. p.475-498. 
GOEDERT, W.J.; SOUZA, P.I. de M de. Culturas anuais: situação atual e perspectivas. In: SIMPOSIO SOBRE O CERRADO, 7., 1989, Brasília, DF. Estratégias de ultilização: anais. 2.ed. Planaltina : EMBRAPA-CPAC, 1997. p.138-157.

GOEDERT, W.J.; LOBATO, E.; WAGNER, E. Potencial agrícola da região dos cerrados brasileiros. Pesquisa Agropecuária Brasileira, Brasília, v.15, p.1$17,1980$.

GOMES, F.P. Curso de estatística experimental. 4.ed. Piracicaba : ESALQ, 1970. 430p.

GONZALES-ÉRICO, E.; KAMPRATH, E.J.; NADERMAN, G.C. et al. Effects of depth of lime incorporation on the growth of corn on an oxisoil of Central Brazil. Soil Science Society of America Journal, Madison, v.43, p. $1155-1158,1979$.

GROHMANN, F.; QUEIROZ NETO, J.P. de. Efeito da compactação artificial de dois solos limo-argilosos sobre a penetração das raízes de arroz. Bragantia, Campinas, v.25, n.38, p.421-431, 1966.

GUEDES, L.V.M.; WILES, T.L.; VEDDATO, R.D. Sistema de manejo do solo de longo prazo com comparações entre plantio direto, preparo mínimo e plantio convencional. In: SEMINÁRIO NACIONAL DE PESQUISA DA SOJA, 1., 1978, Londrina, PR. Anais. Londrina : EMBRAPA-CNPSO, 1978. v.1. p.59-65. 
GUIMARÃES, C.M.; CASTRO, T. de A.P. Sistema radicular do feijoeiro e profundidade de aplicação do adubo. Goiânia : EMBRAPA-CNPAF, 1981. 3p. (EMBRAPA-CNPAF. Pesquisa em Andamento, 31).

GUIMARÃES, C.M.; CASTRO, T. de A.P. Sistema radicular do feijoeiro condicionado aos efeitos da profundidade de aplicação e tipo de adubo fosfatado. In: REUNIÃO NACIONAL DE PESOUISA DE FEIJÃO, 1., 1982, Goiânia, GO. Anais. Goiânia : EMBRAPA-CNPAF, 1982. p.138141. (EMBRAPA-CNPAF. Documentos, 1).

GUIMARÃES, C.M. Desenvolvimento radicular e da parte aérea do arroz de terras altas (Oryza sativa L.) em sistemas de plantio direto e convencional. In: CONGRESSO BRASILEIRO DE FISIOLOGIA VEGETAL, 6., 1997, Belém, PA. Resumos. Belém: SBFV, 1997. p.400.

GUIMARÃES, C.M.; BRUNINI, O.; STONE, L.F. Adaptação do feijoeiro (Phaseolus vulgaris L.) à seca. 1. Densidade e eficiência radicular. Pesquisa Agropecuária Brasileira, Brasília, v.31, n.6, p.393-399, 1996.

GUIMARÃES, C.M.; MOREIRA, J.A.A. Influência da compactação do solo sobre o desenvolvimento da parte aérea e radicular do rroz de terras altas (Oryza sativa L.) In: CONGRESSO BRASILEIRO D FISIOLOGIA VEGETAL, 6., 1997, Belém, PA. Resumos. Belém: SBFV, 997. p.401.

HAAG, H.P.; MALAVOLTA, E.; GARGANTINI, H. et al. Absorção de nutrientes pela cultura do feijoeiro. Bragantia, Campinas, v.26, n.30, p.381-391, 1967. 
HARRIS, R.F.; CHESTERS, G.; ALLEN, O.N. Dynamics of soil agregation. Advances in Agronomy, New York, v.18, p.107-169, 1966.

HEBBLETHWAITE, J. F. The contribuition of no-till to sustainable and environmentally beneficial crop prodution: a global perspective. In: CONGRESSO NACIONAL DE AAPRESID, 5., 1997, Mar del Plata. Conferências. [S.I. : s.n.], 1997. p.79-90.

HERNANI, L.C. Manejo e conservação de recursos naturais da região Oeste do Brasil. In: EMBRAPA. Centro de Pesquisa Agropecuária do Oeste (Dourados, MS). Milho: informações técnicas. Dourados, 1997. p.3967. (EMBRAPA-CPAO. Circular Técnica, 5).

HILL, R.L. Long-term conventional and no-tillage effects on selected soil physical properties. Soil Science Society of America Journal, Madison, v.54, n.1, p.161-166, 1990.

HIROCE, R.; FURLANI, A.M.C.; LIMA, M. Extração de nutrientes na colheita por populações e híbridos de milho. Campinas: IAC, 1989. 24p. (IAC. Boletim Científico, 17).

HUGHES, K.A.; HORNE, D.J.; ROSS, C.W. et al. A 10-year maize/oats rotation under three tillage systems: 2. plant population, root distribution and forage yields. Soil \& Tillage Research, Amsterdam, v.22, p.145157, 1992. 
INFORZATO, R. Sistema radicular do feijoeiro em dois tipos de solo do Estado de São Paulo. Bragantia, Campinas, v.22. n.2, p.477-482, 1963.

ISMAIL, I.; BLEVINS, R.L.; FRYE, W.W. Long-term no-tillage effects on soil properties and continuous corn yields. Soil Science Society of America Journal, Madison, v.58, n.1, p.193-198, 1994.

JANSEN, B.H.; WEERT, R. Van Der. The influence of fertilizer, soil organic matter and soil compaction on maize yields on the Surinam zanderej soils. Plant and Soil, The Hague, v.46, n.2, p.445-459, 1977.

JASTER, F.; ELTZ, F.F.L.; FERNANDES, F.F. et al. Rendimento de grãos de diferentes sistemas de preparo e manejo do solo. Londrina : EMBRAPACNPSO, 1993. 37p. (EMBRAPA-CNPSO. Documentos, 61).

KASPER, T.C. Growth and development of soybean root system. In: WORLD SOYBEANS RESEARCH CONFERENCE, 3., 1984, Ames. Proceedings. Boulder: Westview, 1985. p.841-847.

KASPER, T.C.; STANLEY, C.D.; TAYLOR, H.M. Soybean root growth during the reproductives stages of development. Agronomy Journal, Madison, v.70, p.1105-1107, 1978.

KER, J.C.; PEREIRA, N.R.; CARVALHO JUNIOR, W. de et al. Cerrado: Solos, aptidão e potencialidade agrícola. In: SIMPÓSIO SOBRE MANEJO E CONSERVAC̣Ão DO SOlO NO CERRADO, 1., 1990, Goiânia, Go. Anais. Campinas: Fundação Cargill, 1992. p.1-31. 
KIEHL, E.J. Manual de edafologia: reiações solo-planta. São Paulo : Ceres, 1979. 264p.

KLUTHCOUSKI, J.; AIDAR, H.; TEIXEIRA, M.G. et al. Profundidade de incorporação de adubos para o feijão (Phaseolus vulgaris L.). In: REUNIÃO NACIONAL DE PESQUISA DE FEIJÃO, 1., 1982, Goiânia, GO. Anais. Goiânia : EMBRAPA-CNPAF, 1982. p.142-143. (EMBRAPACNPAF. Documentos, 11 .

KLUTHCOUSKI, J.; PINHEIRO, B.S.; YOKOYAMA, L.P. O arroz nos sistemas de cultivo do cerrado. In: CONFERÊNCIA INTERNACIONAL DE ARROZ PARA A AMÉRICA LATINA E O CARIBE, 9., 1994, Goiânia, GO. Arroz na América Latina: perspectivas para o incremento da produção e do potencial produtivo. Goiânia : EMBRAPA-CNPAF, 1995. v.1. p.95-115. (EMBRAPA-CNPAF. Documentos, 60).

KLUTHCOUSKI, J.; SEGUY, L.; BOUZINAC, S. et al. O arroz nos sistemas agrícolas do cerrado. In: REUNIÃO NACIONAL DE PESQUISA DE ARROZ, 3., 1987, Goiânia, GO. Anais. Goiânia : EMBRAPA-CNPAF, 1991. p.282-330. (EMBRAPA-CNPAF. Documentos, 25).

KOCHHANN, R.A.; DENARDIN, J.E. Comportamento das culturas de trigo, soja e milho à adubação fosfatada no sistema de plantio direto e preparo convencional. In: SEMINÁRIO INTERNACIONAL DO SISTEMA DE PLANTIO DIRETO, 2., 1997, Passo Fundo, RS. Anais. Passo Fundo : EMBRAPA-CNPT, 1997. p.243-246. 
LANDERS, J.N. Fascículo de experiências de plantio direto no cerrado. Goiânia : APDC, 1995a. 261p.

LANDERS, J.N. Gerenciamento em plantio direto. In: LANDERS, J.N. (Ed.). Fascículos de experiências de plantio direto no cerrado. Goiânia : APDC, 1995b. p.47-52.

LATTANZI, A.R. Manejo de suelos para el cultivo de soja. In: PUIGNAU, J.P. (Ed.). Producción de soja. Montevideo : IICA, 1992. p.25-29. (PROCISUR. Diálogo, 34).

LAZARINI, E.; BELLINGIERI, A.A.; ATHAYDE, M.L.F. Extração e exportação de nutrientes por genótipos de soja, semeados em diferentes épocas. In: CONGRESSO BRASILEIRO DE CIÊNCIA DO SOLO, 25., 1995, Viçosa, MG. Resumos expandidos. Viçosa: SBCS, 1995. v.3. p.1374-1376.

LOPES, A.S. Solos sob "cerrado": características, propriedades e manejo. Piracicaba : POTAFOS, 1983. 162p.

LOPES, A.S. Manual da fertilidade do solo. São Paulo : ANDA/POTAFOS, 1989. 155p.

LOPES, P.R.C.; GOGO, N.P.; LEVIEN, R. Eficácia relativa de tipo e quantidade de resíduos culturais espalhados uniformemente sobre o solo na redução da erosão hídrica. Revista Brasileira Ciência do Solo, Campinas, v.11, n.1, p.71-75, 1987. 
MACHADO, N.F. Ensaio comparativo entre sistemas de plantio direto, convencional, preparo mínimo e direto plus. In: CURSO INTENSIVO SOBRE PLANTIO DIRETO NA PALHA, Castro, PR. Resumos. Castro : Fundação ABC, [199-]. p.74-78.

MACKAY, A.D.; BARBER, S.A. Soil moisture affects on root growth and phosphorus uptake by corn. Agronomy Journal, Madison, v.77, n.4, p.519-523, 1985.

MAIA, J.C.S.; ELTZ, F.L.F. Avaliação da cultura da soja (G/ycine max L.) submetida a dois sistemas de preparo do solo sob vegetação de cerrados; III. Percentagem de raízes. In: CONGRESSO BRASILEIRO DE ENGENHARIA AGRíCOLA, 20., 1991, Londrina, PR. Anais. Londrina : SBEA, 1992. v.2. p.869-882.

MALAVOLTA, E. Manual de química agrícola. 2.ed. São Paulo : Ceres, 1967. 606p.

MALAVOLTA, E.; VITTI, G.C.; OLIVEIRA, S.A. de. Avaliação do estudo nutricional das plantas: princípios e aplicações. Piracicaba : POTAFOS, 1989. $201 p$.

MALAVOLTA, E.; HAAG, H.P.; MELLO, F.A.F. de. et al. Nutrição mineral e adubação de plantas cultivadas. São Paulo : Pioneira, 1974. 727p. 
MALLARINO, A.P. Manejo de fósforo e potásio y starters para maiz y soya en siembra directa. In: CONGRESSO NACIONAL DE AAPRESID, 5. 1997, Mar del Plata. Conferências. [S.I. : s.n.], 1997. p.11-19.

MANFRON, P.A.; LIBARDI, P.L.; PAULETTO, E.A. et al. Efeito do método de preparo do solo na distribuição radicular do milho (Zea mays L.) em terra roxa estruturada. Ciência Rural, Santa Maria, v.21, n.3, p.353366, 1991.

MARCHNER, H. Mineral nutrition of higher plants. London : Academic Press, 1986. 624p.

MENGEL, D.B.; BARBER, S.A. Development and distribution of the corn root system under field conditions. Agronomy Journal, Madison, v.68, n.3, p.341-344, 1974.

MERTEN, G.H. Rendimento de grãos de feijão em diferentes sistemas de preparo do solo com tração animal. In: REUNIÃO BRASILEIRA DE MANEJO E CONSERVAC̣ÃO DO SOLO E DA ÁGUA, 10., 1994, Florianópolis, SC. Resumos. Florianópolis: SBCS, 1994. p.178-179.

MILLER, D.E. Root systems in relation to stress tolerance. HortScience, Alexandria, v.21, n.4, p.963-970, 1986.

MONDARDO, A. Manejo e conservação do solo. In: FUNDAC̣ÃO CARGILL. Plantio direto no Brasil. Campinas, 1984. p.53-78. 
MORAES, M.H.; BENEZ, S.H.; LIBARDI, P.L. Influência de camadas compactadas de subsuperfície no desenvolvimento do sistema radicular de soja (G/ycine max (L.) Merrill). Cientifica, Jaboticabal, V.19, n.1, p.195-206, 1991.

MORAES, M.H.; BENEZ, S.H.; LIBARDI, P.L. Efeitos da compactação em algumas propriedades físicas do solo e seu reflexo no desenvolvimento das raízes de plantas de soja. Bragantia, Campinas, v.54, n.2, p.393403, 1995.

MORAIS, J.F.V.; RABELO, N.A. Um método simples para a digestão de amostras de plantas. Goiânia : EMBRAPA-CNPAF, 1986. 12p. (EMBRAPA-CNPAF. Documentos, 12).

MOREIRA, J.A.A.; SANTOS, A.B. dos; DINIZ, A.J. Relação massa/volume e retenção de água de um Latossolo Vermelho amarelo de Jussara, GO. In: CONGRESSO BRASILEIRO DE CIÊNCIA DO SOLO, 25., 1995, Viçosa, MG. Resumos expandidos. Viçosa: SBCS, 1995. v.4. p.21542156.

MULLINS, C.A.; TOMPKINS, F.D.; PARKS, W.L. Effects of tillage methods on soil nutrient distribution, plant nutrient absorption, stand and yield of snap beans and lima beans. Journal of the American Society for Horticultural Science, Alexandria, v.113, n.5, p.667-669, 1988. 
MULLINS, G.L. Soil managenent under no-tillage: chemical aspects. In: SIMPOSIO INTERNACIONAL DO SISTEMA DE PLANTIO DIRETO, 1., 1995, Passo Fundo, RS. Resumos. Passo Fundo : EMBRAPA-CNPT, 1995. p.121-125.

MULLINS, C.A.; STRAW, R.A. Production of snap beans as effected by soil tillage method and row spacing. Journal of American Society of Horticultural Science, Alexandria, v.113, n.5, p.667-669, 1988.

MUZILLI, O. Influência do sistema de plantio direto, comparado ao convencional, sobre a fertilidade da camada arável do solo. Revista Brasileira de Ciência do Solo, Campinas, v.7, n.1, p.95-102, 1983.

MUZILLI, O. Manejo da fertilidade do solo. In: IAPAR (Londrina, PR). Plantio direto no Estado do Paraná. Londrina, 1984. p.43-57. (IAPAR. Circular, 23).

MUZILLI, O. Cultura da soja: princípios e perspectivas de expansão. In: IAPAR (Londrina, PR). Plantio direto no Estado do Paraná. Londrina, 1981a. p.11-14. (IAPAR. Circular, 23).

MUZILLI, O. Desenvolvimento e produtividade das culturas. In: IAPAR (Londrina, PR). Plantio direto no Estado do Paraná. Londrina, 1981b. p.199-203. (IAPAR. Circular, 23).

MUZILLI, O.; OLIVEIRA, E.L. da; CALEGARI, A. Adubação do milho. Campinas : Fundação Cargill, 1989. 29p. 
NANAGARA, T.; PHILLIPS, R.E.; LEGGET, J.E. Diffusion and mass flow of nitrate-nitrogen into corn roots grown under field conditions. Agronomy Journal, Madison, v.68, p.67-72, 1976.

NEWELL, R.O.; WILHELM, W.W. Conservation tillage and irrigation effects on corn root development. Agronomy Journal, Madison, v.79, n.1, p.160-165, 1987.

NEWMAN, E.I. A method for estimating the total lenght of roots in a sample. Journal of Applied Ecology, Oxford, v.3, p.139-145, 1966.

OHNO, Y.; MARUR, C.J. Physiological analysis of factors limiting growth and yield of upland rice. In: IAPAR (Londrina, PR). Annual report of the physiological study of rice 1976-77. Londrina, 1977. 17p.

OLIVEIRA, E.F. de; BAIRRÃO, J.F.M.; CARRADO, I.M. Efeito do sistema de preparo do solo nas suas características físicas e químicas e no rendimento de trigo e soja em latossolo roxo: I. resultados obtidos de 1982 a 1988. Cascavel : OCEPAR, 1990. 54p. (OCEPAR. Resultados de Pesquisa, 4).

OLIVEIRA, E.F. de.; BAIRRÃO, J.F.M.; GOELZER, L.F.D. et al. Avaliação do sistema de manejo do solo na sucessão soja/trigo. In: OCEPAR (Cascavel, PR). Resultados de pesquisa na safra verão 1986/87. Cascavel, 1988a. p.129-130. 
OLIVEIRA, E.F. de; BAIRRÃO, J.F.M.; CARRARO, I.M. et al. Efeito dos sistemas de preparo do solo sobre algumas características físicas e rendimentos de grãos de soja e milho. In: OCEPAR (Cascavel, PR). Resultados da pesquisa na safra de verão 1987/88. Cascavel, 1989. p.233-237.

OLIVEIRA, E.F. de; BAIRRÃO, J.F.M.; GOELZER, L.F.D. et al. Efeito do preparo do solo e da rotação de culturas sobre o rendimento de grãos de soja e milho. In: OCEPAR (Cascavel, PR). Resultados da pesquisa na safra de verão 1986/87. Cascavel, 1988b. p.33-135.

OLIVEIRA, F.A. de; SILVA, J.J.S. Evapotranspiração, índice de área foliar e desenvolvimento radicular do feijão irrigado. Pesquisa Agropecuária Brasileira, Brasília, v.25, n.3, p.317-322, 1990.

OLIVEIRA, I.P. de; ARAUJO, R.S.; DUTRA, L.G. Nutrição mineral e fixação biológica de nitrogênio. In: ARAUJO, R.S.; RAVA, C.A.; STONE, L.F.; ZIMMERMANN, M.J. de O. (Coord.). Cultura do feijoeiro comum no Brasil. Piracicaba : POTAFOS, 1996. p.169-221.

OLIVEIRA, S.A. de.; CASSOL, J.J. Níveis de suficiência de nutrientes no solo e nas folhas para a soja no município de Campo Novo do ParecisMT. In: CONGRESSO BRASILEIRO DE CIÊNCIA DO SOLO, 25., 1995, Viçosa, MG. Resumos expandidos. Viçosa : SBCS, 1995. v.2. p.562563. 
PAULETTI, V.; VIEIRA, S.M.; SANTOS, A.F. dos. et al. Avaliação da fertilidade do solo em profundidade e da palhada em áreas sob plantio direto. In: CONGRESSO BRASILEIRO DE CIÊNCIA DO SOLO, 25., 1995, Viçosa, MG. Resumos expandidos. Viçosa : SBCS, 1995. v.2. p.630632.

PAULETTO, E.A.; PEDROTTI, A.; CRESTANA, S. Avaliação da compactação de um planossolo submetido a diferentes sistemas de cultivos através da tomografia computadorizada e do penetrômetro. In: SEMINÁRIO INTERAMERICANO DO SISTEMA DE PLANTIO DIRETO, 2., 1997, Passo Fundo, RS. Anais. Passo Fundo: EMBRAPA-CNPT, 1997. p.143-146.

PECK, T.R. Plant analysis for production agriculture. In: SOIL AND PLANT ANALYSIS WORKSHOP, 7., 1979, Bridgetown. Proceedings. Bridgetown: [s.n.], 1979. p.1-45.

PEDO, F.; MIELNICZUK, J.; MEDEIROS, J.C. Rendimento e distribuição de raízes em dois níveis de compactação do solo. In: CONGRESSO BRASILEIRO DE CONSERVAC̣ÃO DO SOLO, 6., 1986, Campo Grande, MS. Resumos. Campinas : Fundação Cargill, 1986. p.14.

PHILLIPS, R.S.; KICKHAM, D. Soil compaction in the field and corn growth. Agronomy Journal, Madison, v.54, p.29-34, 1962.

PIGGOTT, T.J. Vegetable crops. In: REUTER, D.J.; ROBINSON, J.B. (Ed.). Plant analysis: an interpretation manual. Melbourne : Inkarta Press, 1986. p.148-187. 
PIRES, R.C. de M.; ARRUDA, F.B.; FUJIWARA, M. et al. Profundidade do sistema radicular das culturas de feijão e trigo sob pivô central. Bragantia, Campinas, v.50, n.1, p.153-162, 1991.

PÖTTKER, D. Métodos de aplicação de fósforo em plantio direto. In: SIMPÓSIO INTERNACIONAL DO SISTEMA DE PLANTIO DIRETO, 2., 1997, Passo Fundo, RS. Anais. Passo Fundo : EMBRAPA-CNPT, 1997. p.247-248.

PRIMAVESI, A. Manejo ecológico do solo: a agricultura em regiões tropicais. 9.ed. São Paulo: Nobel, 1990. 549p.

PRIMAVESI, O.; MELLO, F.A.F. de.; MURAOKA, T. Produção de matéria seca, concentração e acúmulo de nutrientes no feijoeiro (Phaseolus vulgaris L.), em dois solos sujeitos à compactação. Anais da Escola Superior de Agricultura Luis de Queiroz, Piracicaba, v.42, n.2, p.327$362,1985$.

PROFFITT, A.P.B.; BERLINER, P.R.; OOSTERHUIS, D.M. A comparative study of root distribuition and water extraction efficiency by wheat grown under high- and low-frequency irrigation. Agronomy Journal, Madison, v.77, n.5, p.655-662, 1985.

RAIJ, B. Van. Fertilidade do solo e adubação. São Paulo : Agronomica Ceres/POTAFOS, 1991. 343p. 
RAIJ, B. Van; FEITOSA, C.T.; CANTARELLA, H. et al. A análise de solo para descriminar respostas à adubação para a cultura do milho. Bragantia, Campinas, v.40, p.57-75, 1981.

RAMOS, M.; DEDECEK, R. Efeito de sistemas de preparo do solo na produção de soja. Pesquisa Agropecuária Brasileira, Brasília, v.14, n.2, p.149-153, 1979.

REEVES, D.W. Soil management under no-tillage soil physical aspects. In: SIMPOSIO INTERNACIONAL DO SISTEMA DE PLANTIO DIRETO, 1., 1995, Passo Fundo, RS. Resumos. Passo Fundo : EMBRAPA-CNPT, 1995. p. $121-125$.

RESCK, D.V.S.; FERREIRA, C. de A.; GOMES, A.C. et al. Efeito do plantio direto e do arado de discos nas propriedades físicas de um Latossolo Vermelho escuro argiloso sob vegetação de cerrados. In: CONGRESSO BRASILEIRO DE CIÊNCIA DO SOLO, 25., 1995. Viçosa, MG. Resumos expandidos. Viçosa : SBCS, 1995. v.4. p.1840-1842.

RESENDE, M.; FRANC̣A, G.E.; ALBUQUERQUE, P.E.P. et al. Estimativa do desenvolvimento radicular do milho irrigado em dois tipos de solo. In: CONGRESSO NACIONAL DE MILHO E SORGO, 18., 1990, Vitória, ES. Resumos. Vitória : EMCAPA, 1990. p.133. (EMCAPA. Documentos, 65). 
ROBERTSON, L.S.; CHRISTENSON, D.R.; SMUCKER, A.J.M. et al. Tillage systems. In: ROBERTSON, L.S.; FRAIZER, R.D. (Ed.). Dry bean production: principles and practices. [S.I.] : Michigan State University, 1978. p.79-93.

ROBERTSON, W.K.; HAMMOND, L.C.; JONSON, J.T. et al. Effects of plant-water stress on root distribution of corn, soybeans, and peanuts in sandy soil. Agronomy Journal, Madison, v.72, n.5, p.548-550, 1980.

RODER, W.; MASON, S.C.; CLEGG, M.D. et al. Crop root distribution as influenced by grain sorghum-soybean rotation and fertilization. Soil Science Society of American Journal, Madison, v.53, p.1464-1470, 1989.

ROS, C.O. da; SECCO, D.; FIORIN, J.E. et al. Manejo do solo a partir de campo nativo: efeito sobre a forma e estabilidade da estrutura ao final de cinco anos. Revista Brasileira Ciência do Solo, Campinas, v.21, n.2, p.241-247, 1997.

ROVIRA, L.A.A. Estudo do sistema radicular do feijoeiro (Phaseolus vulgaris L.). var carioca. Piracicaba : ESALQ, 1975. 87p. Tese (Doutor em Solos e Nutrição de Plantas) - Escola Superior de Agricultura "Luiz de Queiroz", Universidade de São Paulo, 1975.

SÁ, J.C. de M. Manejo da fertilidade do solo no plantio direto. Castro : Fundação ABC, 1993. 96p. 
SÁ, J.C. de M. Efeito do método de calagem em um LEa argiloso sob longo período de plantio direto com elevada acidez. In: CONGRESSO BRASILEIRO DE CIÊNCIA DO SOLO, 25., 1995, Viçosa, MG. Resumos expandidos. Viçosa: SBCS, 1995. v.2. p.1108-1110.

SÁ, J.C. de M. Reciclagem de nutrientes dos resíduos culturais, processos de transformação e estratégia de fertilização para a produção de grãos no sistema de plantio direto. In: CONGRESSO NACIONAL DE AAPRESID, 5., 1997, Mar del Plata. Conferências. [S.I. : s.n.], 1997. p.99-131.

SANCHEZ, P.A.; LOGAN, T.J. Myths and science about the chemistry and fertility of soils in the tropics. In: LAL, R.; SANCHEZ, P.A. (Ed.). Myths and science of soil of the tropics. Madison: SSSA/ASA, 1992. p.35-46. (SSSA. Special Publication, 29).

SANDANIELO, A.; SILVA, S.C. da.; STEINMETZ, S. Recomendações de épocas de plantio para o arroz de sequeiro em Mato Grosso. Cuiabá : EMPAER-MT, 1992. 48p. (EMPAER-MT. Boletim de Pesquisa, 1).

SARAIVA, O.F.; TORRES, E. Estimação da cobertura do solo por resíduos culturais. Londrina : EMBRAPA-CNPSo, 1993. 4p. (EMBRAPA-CNPSO. Pesquisa em Andamento, 14). 
SARAIVA, O.F.; TORRES, E. Incorporação de restos culturais e cobertura do solo condicionados por sistemas de preparo do solo, na cultura de soja. In: REUNIÃO DE PESQUISA DA SOJA NA REGIÃO CENTRAL DO BRASIL, 19., 1997, Jaboticabal, SP. Ata e resumos. Londrina : EMBRAPA-CNPSo, 1997. p.179. (EMBRAPA-CNPSo. Documentos, 107).

SARTORATO, A.; RAVA, C.A.; RIOS, G.P. Doenças fúngicas e bacterianas da parte aérea. In: ARAUJO, R.S.; RAVA, C.A.; STONE, L.F.; ZIMMERMANN, M.J. de O. (Coord.). Cultura do feijoeiro comum no Brasil. Piracicaba : POTAFOS, 1996. p.669-700.

SCHENK, M.K.; BARBER, S.A. Potassium and phosphorus uptake by corn genotypes grown in the field as influenced by root characteristics. Plant and Soil, The Hague, v.54, p.65-75, 1980.

SEGUY, L.; BOUZINAC, S. Arroz de sequeiro na fazenda Progresso: 4550 kg/ha. Piracicaba : POTAFOS, 1992. 3p. (POTAFOS. Informações Agronômicas, 58).

SEGUY, L.; BOUZINAC, S. Os sistemas de culturas para a região do Médio Norte do Mato Grosso: recomendações técnicas. [S.I. : s.n.], 1993. $58 p$.

SEguY, L.; BOUZINAC, S. R. P.; PACHECO, A. et al. Perspectiva de fixação da agricultura na região Centro-Norte do Mato Grosso. [S.I.] : EMPA-MT/EMBRAPA-CNPAF/CIRAD-IRAT, 1989. 52p. 
SEGUY, L.; BOUZINAC, S.; MATSUBARA, M. Gestão dos solos e das culturas nas fronteiras agricolas dos cerrados úmidos do Centro-Oeste. Lucas do Rio Verde : CIRAD, 1992b. 117p. (Convênio RAP/CIRAD-CA Fazenda Progresso).

SEGUY, L.; BOUZINAC, S.R.; MATSUBARA, M. et al. Gestão dos solos e das culturas nas fronteiras agrícolas dos cerrados úmidos do CentroOeste: I. destaques 1992 e síntese atualizada 1986/92. II. gestão ecológica dos solos : relatório. Lucas do Rio Verde : CIRAD, 1992a. 107p. (Convênio RAP/CIRAD-CA Fazenda Progresso).

SEGUY, L.; KLUTHCOUSKI, J.; SILVA, J.G. et al. Técnicas de preparo do solo: efeitos na fertilidade e na conservação do solo, nas ervas daninhas e na conservação de água. Goiânia: EMBRAPA-CNPAF, 1984. 26p. (EMBRAPA-CNPAF. Circular Técnica, 17).

SHAXSON, T. No cerrado, é preciso construir o solo antes de produzir. Plantio Direto, Passo Fundo, p.8, n.especial, mar. 1995.

SIDIRAS, N.; DERPSCH, R.; MONDARDO, A. Influência de diferentes sistemas de preparo do solo na variação da umidade e rendimento da soja, em Latossolo roxo distrófico (oxisol). Revista Brasileira de Ciência do Solo, Campinas, v.7, n.1, p.103-106, 1983.

SILBERBUSH, M.; BARBER, S.A. Phosphorus and potassium uptake of fieldgrown soybean cultivars predicted by a simulation model. Soil Science Society of America Journal, Madison, v.48, p.592-596, 1984. 
SILVA, S.C. da.; ASSAD, E.D.; LOBATO, E.J.V. et al. Zoneamento agroclimático para o arroz de sequeiro no Estado de Goiás. Brasília : EMBRAPA-SPI, 1994. 80p. (EMBRAPA-CNPAF. Documentos, 43).

SILVA, V.A. da; ANDRADE, M.J.B. de; RAMALHO, M.A.P. et al. Efeitos de métodos de preparo do solo e níveis de fertilizante NPK sobre o feijão da "seca" (Phaseolus vulgaris L.) em seqüência à cultura do milho. In: REUNIÃO NACIONAL DE PESQUISA DE FEIJÃO, 5., 1996, Goiânia, GO. Anais. Goiânia : EMBRAPA-CNPAF, 1996. v.1. p.418-420. (EMBRAPACNPAF. Documentos, 69).

SILVEIRA, G.M. da.; FERREIRA FILHO, A.W.P.; FREITAS, J.G. de et al. Efeitos do plantio direito em ocupação com o plantio convencional nas produções de trigo e na soja. In: CONGRESSO BRASILEIRO DE ENGENHARIA AGRICOLA, 11., 1981, Brasília, DF. Anais. Brasília : Editerra, 1983. v.2. p.923-928.

SILVEIRA, P.M. da.; SILVA, J.G. da. Efeito do preparo do solo e da rotação de culturas sobre o rendimento do feijoeiro irrigado. In: REUNIÃO NACIONAL DE PESQUISA DE FEIJÃO, 5., 1996, Goiânia, GO. Anais. Goiânia : EMBRAPA-CNPAF, 1996. v.1. p.462-464. (EMBRAPA-CNPAF. Documentos, 69).

SILVEIRA, P.M. da.; SILVA, S.C. da; SILVA, O.F. da et al. Estudos de sistemas agrícolas irrigados. Pesquisa Agropecuária Brasileira, Brasília, v.29, n.8, p.1243-1252, 1994. 
SIQUEIRA, R.; YAMAOKA, R.S.; CASÃO JUNIOR, R. et al. Sistemas de preparo e coberturas vegetais em um solo de baixa aptidão agrícola. In: ENCONTRO LATINO AMERICANO SOBRE PLANTIO DIRETO NA PEQUENA PROPRIEDADE, 1., 1993, Ponta Grossa, PR. Anais. Ponta Grossa: IAPAR, 1993. p.221-237.

SPONCHIADO, B.N.; WHITE, J.W.; CASTILLO, R. et al. Root growth of four common bean cultivars in relation to drought tolerance in environments with contrasting soil types. Experimental Agriculture, London, v.25, p.249-257, 1989.

STANLEY, C.D.; KASPAR, T.C.; TAYLOR, H.M. Soybean top and root response to temporary water table imposed at three different stages of growth. Agronomy Journal, Madison, v.22, p.341-346, 1980.

STEINHARDT, G.C. Compactação do solo: um problema oculto. Piracicaba : POTAFOS, 1983. 3p. (POTAFOS. Informações Agronômicas, 21).

STONE, L.F.; MOREIRA, J.A.A. Desenvolvimento radicular de cultivares de arroz em diferentes sistemas de preparo do solo, sob irrigação suplementar por aspersão. In: REUNIÃO NACIONAL DE PESQUISA DE ARROZ, 6., 1998, Goiânia, GO. Perspectivas para a cultura do arroz nos ecossistemas de várzeas e terras altas. Goiânia : EMBRAPA-CNPAF, 1998. p.103-106. (EMBRAPA-CNPAF. Documentos, 85). 
STONE, L.F.; MOREIRA, J.A.A. Resposta de dois cultivares de feijão a diferentes lâminas de irrigação, sob diferentes preparos do solo. In: CONGRESSO BRASILEIRO DE CIÊNCIA DO SOLO, 25., 1995, Viçosa, MG. Resumos expandidos. Viçosa: SBCS, 1995. p.1743-1745.

STONE, L.F.; MOREIRA, J.A.A. Resposta do arroz de sequeiro à profundidade de aração, adubação potássica e condições hídricas do solo. Pesquisa Agropecuária Brasileira, Brasília, v.31, n.12, p.885-895, 1996.

STONE, L.F.; PEREIRA, A.L. Sucessão arroz-feijão irrigados por aspersão: efeitos de espaçamento entre linhas, adubação e cultivar no crescimento, desenvolvimento radicular e consumo d'água do arroz. Pesquisa Agropecuária Brasileira, Brasília, v.29, n.10, p.1577-1592, 1994a.

STONE, L.F.; PEREIRA, A.L. Sucessão arroz-feijão irrigados por aspersão: efeitos de espaçamento entre linhas, adubação e cultivar no crescimento, desenvolvimento radicular e consumo d'água do feijoeiro. Pesquisa Agropecuária Brasileira, Brasília, v.29, n.6, p.939-954, 1994 b.

STONE, L.F.; SANTOS, A.B. dos; STEINMETZ, S. Influência de práticas culturais na capacidade de retenção de água do solo e no rendimento do arroz-de-sequeiro. Pesquisa Agropecuária Brasileira, Brasília, v.15, n.1, p.63-68, 1980. 
STONE, L.F.; SILVEIRA, P.M. da. Efeito do preparo do solo na compactação e disponibilidade de água do solo e no desenvolvimento radicular e produtividade do feijoeiro irrigado por aspersão. In: REUNIÃO NACIONAL DE PESQUISA DE FEIJÃO, 5., 1996, Goiânia, GO. Anais. Goiânia : EMBRAPA-CNPAF, 1996. v.1. p.459-461. (EMBRAPA-CNPAF. Documentos, 69).

TANAKA, R.T.; MASCARENHAS, H.A.A.; BORKERT, C.M. Nutrição mineral da soja. In: SIMPÓSIO SOBRE A CULTURA DA SOJA NO CERRADOS, 1992, Uberaba, MG. Cultura da soja nos cerrados. anais. Piracicaba : POTAFOS, 1993. p.105-135.

TAYLOR, H. M. Methods of studying root systems in the field. HortScience, Alexandria, v.21, n.4, p.952-956, 1986.

TEIXEIRA, D.M.C., MAIA, A. de H.N.; CORNAT, B. Profundidade efetiva de raízes em feijoeiro irrigado. Parnaiba : EMBRAPA-CNPAI, 1992. 4p. (EMBRAPA-CNPAI. Pesquisa em Andamento, 17).

THUNG, M.; ORTEGA, J.; RODRIGUEZ, R. Respuesta y aprovechamiento del fósforo aplicado a dos profundidades y su efecto en el rendimento del frijol (Phaseolus vulgaris L.). In: REUNIÃO NACIONAL DE PESQUISA DE FEIJÃO, 1., 1982, Goiânia, GO. Anais. Goiânia : EMBRAPA-CNPAF, 1982. p.205. (EMBRAPA-CNPAF. Documentos, 1). 
TORRES, E.; GALERANI, P.R.; SARAIVA, O.F. Avaliação de sistemas de produção de soja: manejo, rotação e cultivares. In: REUNIÃO DE PESQUISA DE SOJA DA REGIÃO CENTRAL DO BRASIL, 17., 1995b, Goiânia, GO. Ata e resumos. Goiânia : EMGOPA, 1995a. p.117. (EMGOPA. Documentos, 28).

TORRES, E.; GAZZIERO, D.L.P.; GALERANI, P.R. et al., Avaliação de sistemas de preparo do solo e semeadura da soja. In: EMBRAPA. Centro Nacional de Pesquisa de Soja (Londrina, PR). Resultados de pesquisa de soja 1987/88. Londrina, 1988. p.237. (EMBRAPA-CNPSo. Documentos, 36).

TORRES, E.; SARAIVA, O.F. Comportamento da compactação do solo no plantio direto e avaliação do seu efeito sobre o desenvolvimento do sistema radicular e produtividade de cultivares de soja. In: REUNIÃO NACIONAL DE PESQUISA DE SOJA NA REGIÃO CENTRAL DO BRASIL. 19., 1997, Jaboticabal, SP. Ata e resumos. Londrina : EMBRAPACNPSo, 1997. p.181. (EMBRAPA-CNPSo. Documentos, 107).

TORRES, E.; SARAIVA, O.F. Doze anos de manejo do solo em soja: sistema radicular, produtividade e algumas características físicas do solo. In: CONGRESSO BRASIEIRO DE CIÊNCIA DO SOLO, 25., 1995, Viçosa, MG. Resumos expandidos. Viçosa: SBCS, 1995a. v.4. p.1802-1803. 
TORRES, E.; SARAIVA, O.F. Doze anos de manejo do solo em soja: sistema radicular, produtividade e algumas características físicas do solo. In: REUNIÃO DE PESQUISA DA SOJA DA REGIÃO CENTRAL DO BRASIL, 17., 1995, Goiânia, GO. Ata e resumos. Goiânia : EMGOPA, 1995b. p.122-123. (EMGOPA. Documentos, 28).

TORRES, E.; SARAIVA, O.F.; FARIAS, J.R.B. Resposta de diferentes cultivares de soja à compactação do solo. In: REUNIÃO DE PESQUISA DE SOJA DA REGIÃO CENTRAL DO BRASIL, 17, 1995. Goiânia. Ata e resumos... Goiânia. EMGOPA. 1995a. p.126. (EMGOPA, Documentos, 28).

TU, J.C.; TAN, C.S. Effect of soil compaction on growth, yield and root rots of white beans in clay loam and sandy loam soil. Soil Biology and Biochemistry, Oxford, v.23, p.233-238, 1991.

TUITE, J. Plant pathological methods: fungi and bacteria. Minnessota : Burgess Pub., 1969. 239p.

UHDE, L.T.; COGO, N.P.; TREIN, C.R. et al. Comportamento da sucessão trevo/milho, em área com e sem pastejo intensivo, sob diferentes métodos de preparo do solo. Revista Brasileira de Ciência do Solo, Campinas, v.20, n.3, p.493-501, 1996. 
URCHEI, M.A. Efeitos do plantio direto e do preparo convencional sobre alguns atributos físicos de um Latossolo Vermelho escuro argiloso e no crescimento e produtividade do feijoeiro (Phaseolus vulgaris L.) sob irrigação. Botucatu: UNESP, 1996. 131p. Tese (Doutor em Agronomia) - Faculdade de Ciências Agronômicas - Campus de Botucatu, Universidade Estadual Paulista, 1996.

VEIGAS, C.L.; OLIVEIRA, L.B. de. Influência do preparo do solo sobre a distribuição de raízes de soja (Glycine Max (L.) Merrill) em solo podzólico vermelho amarelo. Revista do Centro de Ciências Rurais, Santa Maria, v.6, n.3, p.295-307, 1976.

VIEIRA, M.J. Comportamento físico do solo em plantio direto. In: FANCELLI, A.L. (Coord.). Atualização em plantio direto. Campinas : Fundação Cargill, 1985. p. 161-179.

VIEIRA, M.J. Propriedades físicas do solo. In: IAPAR (Londrina, PR). Plantio direto no Estado do Paraná. Londrina, 1981. p.19-30. (IAPAR. Circular, 23).

VIEIRA, M.J.; MUZILLI, O. Características físicas de um Latossolo Vermelho-Escuro sob diferentes sistemas de manejo. Pesquisa Agropecuária Brasileira, Brasília, v.19, n.7, p.873-882, 1984. 
VITOSH, M.L.; CHRISTENSON, D.R.; KNEZEK, B.D. Plant nutrient requirements. In: ROBERTSON, L.S.; FRAZIER, R.D. (Ed.). Dry bean production: principles and practices. [S.I.] : Michigan State University, 1978. p.94-111.

WAGGER, M.G.; DENTON, H.P. Influence of cover crop and wheel traffic on soil physical properties in continuous no-tillage corn. Soil Science Society of America Journal, Madison, v.53, n.4, p.1206-1210, 1989.

WALKLEY, A.; BLACK, I.A. An examination of the digtyareff method for determining soil organic matter and a proposed modification of the chromic acid titration method. Soil Science, Baltimore, v.37, p.29-38, 1934.

WIERSUM, L.K. The relationship of the size and structural rigidity of pores to their penetration by roots. Plant and Soil, The Hague, v.9, p.75-85, 1957.

WISNIEWSKI, C. HOLTZ, G.P. Decomposição da palhada e liberação de nitrogênio e fósforo numa rotação aveia-soja sob plantio direto. Pesquisa Agropecuária Brasileira, Brasília, v.32, n.11, p.1191-1197, 1997. 


\section{APÊNDICES}


Apêndice 1. Estádios fenológicos da cultura do milho, cv. BR 3123, ciclo de 130 dias, nas condições de Santa Helena, GO'

\begin{tabular}{clc}
\hline Etapa & Evento & Data \\
\hline- & Semeadura & $31 / 10 / 96$ \\
1 & Emergência & $04 / 11 / 96$ \\
2 & $4^{3}$ folha & $27 / 11 / 96$ \\
3 & $8^{\text {a folha }}$ & $17 / 12 / 96$ \\
4 & $12^{3}$ folha & $27 / 12 / 96$ \\
5 & Pendoamento & $31 / 12 / 96$ \\
6 & Florescimento & $04 / 01 / 96$ \\
7 & Grão leitoso & $14 / 01 / 97$ \\
8 & Grão pastoso & $25 / 01 / 97$ \\
9 & Grão farináceo & $30 / 01 / 97$ \\
10 & Grão farináceo-duro & $05 / 02 / 97$ \\
11 & Maturidade fisiológica & $14 / 02 / 97$ \\
- & Colheita & $20 / 02 / 97$ \\
Emergência à colheita & & 108 dias \\
\hline
\end{tabular}

'Baseado na descrição fenológica proposta por Fancelli (1986).

Apêndice 2. Estádios fenológicos da cultura da soja, cv. Estrela, ciclo de 123 dias, nas condições de Santa Helena, GO'

\begin{tabular}{cll}
\hline Estádio & \multicolumn{1}{c}{ Evento } & Data \\
\hline- & Semeadura & $09 / 10 / 96$ \\
$V E$ & Emergência & $14 / 10 / 96$ \\
$V C$ & Abertura das folhas cotiledonares & $16 / 10 / 96$ \\
$V_{1}$ & Aberturas das folhas primárias & $20 / 10 / 96$ \\
$V_{2}$ & Abertura do $1^{\circ}$ trifólio & $23 / 10 / 96$ \\
$V_{3}$ & Abertura do $2^{\circ}$ trifólio & $27 / 10 / 96$ \\
$V_{11}$ & Abertura do $11^{\circ}$ trifólio & $10 / 12 / 96$ \\
$R_{1}$ & Abertura $1^{a}$ flor & $13 / 11 / 96$ \\
$R_{2}$ & Florescimento pleno & $17 / 11 / 96$ \\
$R_{3}$ & Formação $1^{\circ}$ legume & $30 / 11 / 96$ \\
$R_{4}$ & Primeiro legume com 2 cm & $05 / 12 / 96$ \\
$R_{5}$ & Grãos com 3 mm & $16 / 12 / 96$ \\
$R_{6}$ & Máximo volume dos grãos & $06 / 01 / 97$ \\
$R_{7}$ & Maturidade fisiológica & $30 / 01 / 97$ \\
$R_{8}$ & Maturação & $09 / 02 / 97$ \\
- & Colheita & $12 / 02 / 97$ \\
Emergência à colheita & & 124 dias \\
\hline
\end{tabular}

'Baseado na descrição fenológica descrita por Costa e Marchezan (1982). 
Apêndice 3. Estádios fenológicos da cultura do arroz de terras altas, cv. Caiapó, ciclo de 135 dias, nas condições de Santa Helena, GO ${ }^{1}$

\begin{tabular}{clc}
\hline Etapa & Evento & Data \\
\hline- & Semeadura & $08 / 10 / 96$ \\
0 & Emergência & $13 / 10 / 96$ \\
1 & Início do perfilhamento & $27 / 10 / 96$ \\
2 & Perfilhamento máximo & $22 / 11 / 96$ \\
3 & Alongamento do colmo & $05 / 12 / 96$ \\
4 & Primórdio floral & $15 / 12 / 96$ \\
5 & Pré-floração & $01 / 01 / 97$ \\
6 & Floração & $07 / 01 / 97$ \\
7 & Grãos leitosos & $21 / 01 / 97$ \\
8 & Grãos semiduros & $30 / 01 / 97$ \\
9 & Maturação & $08 / 02 / 97$ \\
10 & Colheita & $12 / 02 / 97$ \\
Emergência à colheita & & 122 dias \\
\hline
\end{tabular}

'Baseado na descrição fenológica descrita por Fernandez \& Arregoces (1980).

Apêndice 4. Estádios fenológicos da cultura do feijão, cv. Jalo Precoce, ciclo de 72 dias, nas condições de Santa Helena, GO ${ }^{1}$

\begin{tabular}{clc}
\hline Estádio & Evento & Data \\
\hline- & Semeadura & $17 / 06 / 97$ \\
$\mathrm{~V}_{0}$ & Germinação & $19 / 06 / 97$ \\
$\mathrm{~V}_{1}$ & Emergência & $23 / 06 / 97$ \\
$\mathrm{~V}_{2}$ & Abertura das folhas primárias & $26 / 06 / 97$ \\
$\mathrm{~V}_{3}$ & Abertura 1 ${ }^{\circ}$ trifólio & $05 / 07 / 97$ \\
$\mathrm{~V}_{4}$ & Abertura 30 trifólio & $14 / 07 / 97$ \\
$\mathrm{R}_{5}$ & Pré-floração & $28 / 07 / 97$ \\
$\mathrm{R}_{6}$ & Florescimento pleno & $31 / 07 / 97$ \\
$\mathrm{R}_{7}$ & Formação dos legumes & $05 / 08 / 97$ \\
$\mathrm{R}_{8}$ & Enchimento dos legumes & $12 / 08 / 97$ \\
$\mathrm{R}_{9}$ & Maturidade fisiológica & $26 / 08 / 97$ \\
- & Colheita & $08 / 09 / 97$ \\
Emergência à colheita & & 75 dias \\
\hline
\end{tabular}

\footnotetext{
${ }^{1}$ Baseado na descrição fenológica descrita por Fernandez et al. (1986).
} 
Apêndice 5. Efeito do manejo do solo sobre a produção de matéria seca das plantas daninhas. na gleba 3-A. Fazenda Três Irmãos.

\begin{tabular}{cc}
\hline Manejo & Matéria seca $(k g / h a)^{1}$ \\
\hline PD & $2369 \mathrm{a}^{2}$ \\
GA & $243 \mathrm{bc}$ \\
EP & $640 \mathrm{~b}$ \\
AP & $124 \mathrm{c}$ \\
DMS & 501.05 \\
CV (\%) & 36,74 \\
\hline
\end{tabular}

${ }^{1}$ Coleta 29 dias após o preparo. Média de 6 repetiçōes de $1 \mathrm{~m}^{2} /$ manejo.

'2Médias seguidas da mesma letra. nas colunas, não diferem ao nivel de $\mathrm{P}=0,05$ pelo teste de Tukey.

Apêndice 6. Efeito do manejo do solo sobre a distribuição do $\mathrm{Ca}$, em $\mathrm{cmol}^{\mathfrak{l}} / \mathrm{L}$, no perfil do solo. após a colheita do milho.

\begin{tabular}{lllll}
\hline $\begin{array}{c}\text { Profundidade } \\
(\mathrm{cm})\end{array}$ & \multicolumn{4}{c}{ Manejo do solo } \\
\cline { 2 - 5 } $0-5$ & $5.3 \mathrm{a} \mathrm{A}$ & $4.9 \mathrm{a} \mathrm{A}$ & $5.0 \mathrm{a} \mathrm{A}$ & $4.5 \mathrm{a} \mathrm{A}$ \\
$5-10$ & $4.4 \mathrm{~b} \mathrm{~A}$ & $4.5 \mathrm{ab} \mathrm{A}$ & $4.2 \mathrm{ab} \mathrm{A}$ & $5.0 \mathrm{a} \mathrm{A}$ \\
$10-20$ & $4,2 \mathrm{~b} \mathrm{AB}$ & $3.9 \mathrm{~b} \mathrm{~B}$ & $4,0 \mathrm{~b} \mathrm{~B}$ & $5,0 \mathrm{a} \mathrm{A}$ \\
$20-40$ & $3.3 \mathrm{c} \mathrm{B}$ & $3,1 \mathrm{bc} \mathrm{B}$ & $3.6 \mathrm{~b} \mathrm{~B}$ & $4,6 \mathrm{a} \mathrm{A}$ \\
$40-60$ & $2.7 \mathrm{c} \mathrm{A}$ & $2.5 \mathrm{c} \mathrm{A}$ & $3.1 \mathrm{~b} \mathrm{~A}$ & $3.3 \mathrm{~b} \mathrm{~A}$
\end{tabular}

DMS (profundidade dentro de manejo) $=0.80$ DMS (manejo dentro de profundidade) $=0.93$

\footnotetext{
'Médias seguidas da mesma letra. minúscula na coluna e maiúscula na horizontal, não diferem ao nivel de
} $P=0.05$ pelo teste de Tukey. 
Apêndice 7. Efeito do manejo do solo sobre a distribuição do $\mathrm{Mn}$, em mg/L, no perfil do solo, após a colheita do milho.

\begin{tabular}{lllll}
\hline $\begin{array}{c}\text { Profundidade } \\
(\mathrm{cm})\end{array}$ & \multicolumn{4}{c}{ Manejo do solo } \\
\cline { 2 - 5 } $0-5$ & $90,2 \mathrm{a} \mathrm{A}$ & $54,7 \mathrm{a} \mathrm{B}$ & $62,2 \mathrm{a} \mathrm{B}$ & $50.7 \mathrm{ab} \mathrm{B}$ \\
$5-10$ & $47,5 \mathrm{bc} \mathrm{A}$ & $46,0 \mathrm{ab} \mathrm{A}$ & $43.7 \mathrm{ab} \mathrm{A}$ & $56.0 \mathrm{a} \mathrm{A}$ \\
$10-20$ & $53,7 \mathrm{c} \mathrm{A}$ & $38,7 \mathrm{ab} \mathrm{A}$ & $45,5 \mathrm{ab} \mathrm{A}$ & $51,7 \mathrm{ab} \mathrm{A}$ \\
$20-40$ & $36,2 \mathrm{c} \mathrm{A}$ & $28,0 \mathrm{~b} \mathrm{~A}$ & $37,2 \mathrm{~b} \mathrm{~A}$ & $46,0 \mathrm{ab} \mathrm{A}$ \\
$40-60$ & $26-2 \mathrm{c} \mathrm{A}$ & $25.2 \mathrm{~b} \mathrm{~A}$ & $31.7 \mathrm{~b} \mathrm{~A}$ & $32.2 \mathrm{~b} \mathrm{~A}$ \\
\hline
\end{tabular}

DMS (profundidade dentro de manejo) $=21.89$

DMS (manejo dentro de profundidade) $=26.68$

'Médias seguidas da mesma letra, minúscula nas colunas e maiúsculas na horizontal. não diferem ao nivel de $\mathrm{P}=0.05$ pelo teste de Tukey.

Apêndice 8. Efeito do manejo do solo sobre a distribuição do $\mathrm{Cu}$, em mg/L, no perfil do solo, após a colheita do milho.

\begin{tabular}{lllll}
\hline $\begin{array}{c}\text { Profundidade } \\
(\mathrm{cm})\end{array}$ & \multicolumn{4}{c}{ Manejo do solo } \\
\cline { 2 - 5 } $0-5$ & $3.0 \mathrm{~b} \mathrm{~A}$ & $3.1 \mathrm{~b} \mathrm{~A}$ & $3.4 \mathrm{ab} \mathrm{A}$ & $3.1 \mathrm{ab} \mathrm{A}$ \\
$5-10$ & $2.9 \mathrm{~b} \mathrm{~A}$ & $3.0 \mathrm{~b} \mathrm{~A}$ & $3.3 \mathrm{ab} \mathrm{A}$ & $2.9 \mathrm{~b} \mathrm{~A}$ \\
$10-20$ & $3.1 \mathrm{~b} \mathrm{~A}$ & $3.1 \mathrm{~b} \mathrm{~A}$ & $3.1 \mathrm{~b} \mathrm{~A}$ & $2.6 \mathrm{~b} \mathrm{~A}$ \\
$20-40$ & $3.5 \mathrm{ab} \mathrm{A}$ & $3.6 \mathrm{a} \mathrm{A}$ & $3.5 \mathrm{ab} \mathrm{A}$ & $2.6 \mathrm{~b} \mathrm{~B}$ \\
$40-60$ & $3.9 \mathrm{a} \mathrm{A}$ & $3.7 \mathrm{a} \mathrm{A}$ & $3.9 \mathrm{a} \mathrm{A}$ & $3.5 \mathrm{a} \mathrm{A}$
\end{tabular}

DMS (profundidade dentro de manejo) $=0.53$

DMS (manejo dentro de profundidade) $=0.60$

\footnotetext{
'Médias seguidas da mesma letra. minúscula na coluna e maiúscula na horizontal, não diferem ao nível de $\mathrm{P}=0.05$ pelo teste de Tukey.
} 
Apêndice 9. Efeito do manejo do solo sobre a distribuição de $\mathrm{K}$, em $\mathrm{mg} / \mathrm{L}$, no perfil do solo após a colheita da soja.

\begin{tabular}{lcccc}
\hline $\begin{array}{c}\text { Profundidade } \\
(\mathrm{cm})\end{array}$ & $\mathrm{PD}$ & $\mathrm{GA}$ & $\mathrm{EP}$ & $\mathrm{AP}$ \\
\cline { 2 - 5 } & $138,0 \mathrm{ab} \mathrm{B}$ & $197,2 \mathrm{a} \mathrm{AB}$ & $218,7 \mathrm{a} \mathrm{A}$ & $187,2 \mathrm{a} \mathrm{AB}$ \\
$0-5$ & $137,2 \mathrm{ab} \mathrm{A}$ & $161,2 \mathrm{ab} \mathrm{A}$ & $163,2 \mathrm{~b} \mathrm{~A}$ & $145,7 \mathrm{ab} \mathrm{A}$ \\
$5-10$ & $154,5 \mathrm{a} \mathrm{A}$ & $141,2 \mathrm{~b} \mathrm{~A}$ & $133,0 \mathrm{bc} \mathrm{A}$ & $118,2 \mathrm{~b} \mathrm{~A}$ \\
$10-20$ & $104,0 \mathrm{ab} \mathrm{A}$ & $87,2 \mathrm{c} \mathrm{A}$ & $120,0 \mathrm{bc} \mathrm{A}$ & $108,0 \mathrm{~b} \mathrm{~A}$ \\
$40-40$ & $74.0 \mathrm{~b} \mathrm{~A}$ & $62.5 \mathrm{c} \mathrm{A}$ & $83.2 \mathrm{c} \mathrm{A}$ & $88,0 \mathrm{~b} \mathrm{~A}$
\end{tabular}

DMS (profundidade dentro de manejo) $=50.66$

DMS (manejo dentro de profundidade) $=64,02$

'Médias seguidas da mesma letra, minúscula nas colunas e maiúsculas na horizontal, não diferem ao nível de $\mathrm{P}=0.05$ pelo teste de Tukey.

Apêndice 10. Efeito do manejo do solo sobre a distribuição de $\mathrm{Zn}$, em $\mathrm{mg} / \mathrm{L}$ no perfil do solo, após a colheita da soja.

\begin{tabular}{lcrrl}
\hline $\begin{array}{c}\text { Profundidade } \\
(\mathrm{cm})\end{array}$ & \multicolumn{4}{c}{ Manejo do solo } \\
\cline { 2 - 5 } $0-5$ & $\mathrm{PD}$ & $\mathrm{GA}$ & $\mathrm{EP}$ & $\mathrm{AP}$ \\
$5-10$ & $12.2 \mathrm{a} \mathrm{A}$ & $11.8 \mathrm{a} \mathrm{A}$ & $10.9 \mathrm{a} \mathrm{A}$ & $7.5 \mathrm{a} \mathrm{B}$ \\
$10-20$ & $5.0 \mathrm{~b} \mathrm{~A}$ & $5.9 \mathrm{~b} \mathrm{~A}$ & $7.6 \mathrm{~b} \mathrm{~A}$ & $7.3 \mathrm{ab} \mathrm{A}$ \\
$20-40$ & $3.2 \mathrm{bc} \mathrm{A}$ & $4.2 \mathrm{~b} \mathrm{~A}$ & $4.2 \mathrm{c} \mathrm{A}$ & $4.5 \mathrm{~b} \mathrm{~A}$ \\
$40-60$ & $1.2 \mathrm{c} \mathrm{A}$ & $1.9 \mathrm{c} \mathrm{A}$ & $1.9 \mathrm{c} \mathrm{A}$ & $2.0 \mathrm{bc} \mathrm{A}$ \\
& $1.1 \mathrm{c} \mathrm{A}$ & $1.2 \mathrm{c} \mathrm{A}$ & $1.3 \mathrm{~d} \mathrm{~A}$ & $1.3 \mathrm{c} \mathrm{A}$
\end{tabular}

DMS (profundidade dentro de manejo) $=2.84$

DMS (manejo dentro de profundidade) $=2.96$

${ }^{1}$ Médias seguidas da mesma letra, minúscula na coluna e maiúscula na horizontal, não diferem ao nivel de $\mathrm{P}=0.05$ pelo teste de Tukey. 
Apêndice 11. Efeito do manejo do solo sobre a distribuição do Mn, em mg/L. no perfil do solo. após a colheita da soja.

\begin{tabular}{lllll}
\hline $\begin{array}{c}\text { Profundidade } \\
(\mathrm{cm})\end{array}$ & \multicolumn{4}{c}{ Manejo do solo } \\
\cline { 2 - 5 } $0-5$ & $2,4 \mathrm{a} \mathrm{A}$ & $2,3 \mathrm{a} \mathrm{A}$ & $2,2 \mathrm{a} \mathrm{A}$ & $1,5 \mathrm{ab} \mathrm{B}$ \\
$5-10$ & $1,4 \mathrm{~b} \mathrm{~A}$ & $1,3 \mathrm{~b} \mathrm{~A}$ & $1,4 \mathrm{~b} \mathrm{~A}$ & $1,6 \mathrm{a} \mathrm{A}$ \\
$10-20$ & $1,4 \mathrm{~b} \mathrm{~A}$ & $1,2 \mathrm{~b} \mathrm{~A}$ & $1,2 \mathrm{~b} \mathrm{~A}$ & $1.3 \mathrm{ab} \mathrm{A}$ \\
$20-40$ & $0,8 \mathrm{~b} \mathrm{~B}$ & $1,3 \mathrm{~b} \mathrm{~A}$ & $1,2 \mathrm{~b} \mathrm{AB}$ & $1,2 \mathrm{~b} \mathrm{AB}$ \\
$40-60$ & $0,9 \mathrm{~b} \mathrm{~A}$ & $1,2 \mathrm{~b} \mathrm{~A}$ & $1.1 \mathrm{~b} \mathrm{~A}$ & $1,1 \mathrm{~b} \mathrm{~A}$
\end{tabular}

DMS (profundidade dentro de manejo) $=0.42$

DMS (manejo dentro de profundidade) $=0.42$

'Médias seguidas da mesma letra, minúscula na coluna e maiúscula na horizontal, não diferem ao nível de $\mathrm{P}=0,05$ pelo teste de Tukey.

Apêndice 12. Efeito do manejo do solo sobre a distribuição do $\mathrm{Mg}$, em $\mathrm{cmol}^{\mathrm{c}} / \mathrm{L}$. no perfil do solo. após a colheita do arroz.

\begin{tabular}{lcccc}
\hline $\begin{array}{c}\text { Profundidade } \\
(\mathrm{cm})\end{array}$ & $\mathrm{PD}$ & $\mathrm{GA}$ & $\mathrm{GP}$ & $\mathrm{AP}$ \\
\cline { 2 - 5 } $0-5$ & $2.9 \mathrm{a} \mathrm{A}$ & $2,0 \mathrm{a} \mathrm{B}$ & $2.6 \mathrm{a} \mathrm{AB}$ & $1.2 \mathrm{a} \mathrm{C}$ \\
$5-10$ & $1.5 \mathrm{~b} \mathrm{~A}$ & $1.2 \mathrm{~b} \mathrm{~A}$ & $1,7 \mathrm{~b} \mathrm{~A}$ & $1,2 \mathrm{a} \mathrm{A}$ \\
$10-20$ & $1.6 \mathrm{~b} \mathrm{~A}$ & $1.2 \mathrm{~b} \mathrm{~A}$ & $1,2 \mathrm{~b} \mathrm{~A}$ & $1.1 \mathrm{aA}$ \\
$20-40$ & $1.5 \mathrm{~b} \mathrm{~A}$ & $1.1 \mathrm{~b} \mathrm{~A}$ & $1.3 \mathrm{~b} \mathrm{~A}$ & $1.0 \mathrm{aA}$ \\
$40-60$ & $1.2 \mathrm{~b} \mathrm{~A}$ & $0.9 \mathrm{~b} \mathrm{~A}$ & $1.2 \mathrm{~b} \mathrm{~A}$ & $0.9 \mathrm{a} \mathrm{A}$
\end{tabular}

DMS (profundidade dentro de manejo) $=0.62$

DMS (manejo dentro de profundidade) $=0.64$

\footnotetext{
'Médias seguidas da mesma letra. minúscula na coluna e maiúscula na horizontal, não diferem ao nível de $\mathrm{P}=0.05$ pelo teste de Tukey.
} 
Apêndice 13. Efeito do manejo do solo sobre a distribuição do P, em mg/L no perfil do solo, após a colheita do arroz.

\begin{tabular}{lcccc}
\hline $\begin{array}{c}\text { Profundidade } \\
(\mathrm{cm})\end{array}$ & \multicolumn{4}{c}{ Manejo do solo } \\
\cline { 2 - 5 } $0-5$ & $44,4 \mathrm{a} \mathrm{A}$ & $38,0 \mathrm{a} \mathrm{AB}$ & $32,5 \mathrm{a} \mathrm{AB}$ & $25,3 \mathrm{a} \mathrm{B}$ \\
$5-10$ & $28.5 \mathrm{~b} \mathrm{~A}$ & $31,6 \mathrm{a} \mathrm{A}$ & $31,4 \mathrm{a} \mathrm{A}$ & $26,6 \mathrm{a} \mathrm{A}$ \\
$10-20$ & $19.7 \mathrm{~b} \mathrm{~A}$ & $20.5 \mathrm{~b} \mathrm{~A}$ & $13,6 \mathrm{~b} \mathrm{~A}$ & $21,4 \mathrm{a} \mathrm{A}$ \\
$20-40$ & $7,0 \mathrm{c} \mathrm{A}$ & $4,8 \mathrm{c} \mathrm{A}$ & $8.3 \mathrm{~b} \mathrm{~A}$ & $11,5 \mathrm{~b} \mathrm{~A}$ \\
$40-60$ & $1,6 \mathrm{c} \mathrm{A}$ & $0.9 \mathrm{c} \mathrm{A}$ & $2.3 \mathrm{~b} \mathrm{~A}$ & $1,9 \mathrm{~b} \mathrm{~A}$
\end{tabular}

DMS (profundidade dentro de manejo) $=11.42$

DMS (manejo dentro de profundidade) $=14.56$

'Médias seguidas da mesma letra, minúscula na coluna e maiúscula na horizontal, não diferem ao nível de $\mathrm{P}=0,05$ pelo teste de Tukey.

Apêndice 14. Efeito do manejo do solo sobre a distribuição de K, em mg/L, no perfil do solo, após a colheita do arroz.

\begin{tabular}{lcccc}
\hline $\begin{array}{c}\text { Profundidade } \\
(\mathrm{cm})\end{array}$ & PD & GA & EP & AP \\
\cline { 2 - 5 } $0-5$ & $132,7 \mathrm{~b} \mathrm{~A}$ & $111.5 \mathrm{~b} \mathrm{~A}$ & $128,5 \mathrm{a} \mathrm{A}$ & $83.0 \mathrm{a} \mathrm{A}$ \\
$5-10$ & $184.2 \mathrm{a} \mathrm{A}$ & $158.7 \mathrm{a} \mathrm{A}$ & $137.0 \mathrm{a} \mathrm{A}$ & $83.5 \mathrm{a} \mathrm{B}$ \\
$10-20$ & $154.5 \mathrm{ab} \mathrm{A}$ & $162.7 \mathrm{a} \mathrm{A}$ & $132.7 \mathrm{a} \mathrm{A}$ & $112.5 \mathrm{a} \mathrm{A}$ \\
$20-40$ & $122.7 \mathrm{~b} \mathrm{~A}$ & $122.0 \mathrm{~b} \mathrm{~A}$ & $107.2 \mathrm{ab} \mathrm{A}$ & $103.2 \mathrm{a} \mathrm{A}$ \\
$40-60$ & $78.0 \mathrm{c} \mathrm{A}$ & $89.2 \mathrm{~b} \mathrm{~A}$ & $86.5 \mathrm{~b} \mathrm{~A}$ & $65.5 \mathrm{~b} \mathrm{~A}$
\end{tabular}

DMS (profundidade dentro de manejo) $=39.76$

DMS (manejo dentro de profundidade) $=50.61$

${ }^{1}$ Médias seguidas da mesma letra, minúscula na coluna e maiúscula na horizontal, nào diferem ao nível de $\mathrm{P}=0,05$ pelo teste de Tukey. 
Apêndice 15. Efeito do manejo do solo sobre a distribuição de $\mathrm{Zn}$, em mg/L, no perfil do solo, após a colheita do arroz.

\begin{tabular}{lcccl}
\hline $\begin{array}{c}\text { Profundidade } \\
(\mathrm{cm})\end{array}$ & \multicolumn{4}{c}{ Manejo do solo } \\
\cline { 2 - 5 } $0-5$ & $\mathrm{PD}$ & $\mathrm{GA}$ & $\mathrm{EP}$ & $\mathrm{AP}$ \\
$5-10$ & $11,5 \mathrm{a} \mathrm{A}$ & $9,6 \mathrm{a} \mathrm{A}$ & $9,9 \mathrm{a} \mathrm{A}$ & $4,6 \mathrm{a} \mathrm{B}$ \\
$10-20$ & $6,1 \mathrm{~b} \mathrm{~A}$ & $6,4 \mathrm{~b} \mathrm{~A}$ & $6,1 \mathrm{~b} \mathrm{~A}$ & $5,3 \mathrm{a} \mathrm{A}$ \\
$20-40$ & $4,0 \mathrm{c} \mathrm{AB}$ & $5,6 \mathrm{~b} \mathrm{~A}$ & $2,7 \mathrm{c} \mathrm{B}$ & $3.8 \mathrm{a} \mathrm{AB}$ \\
$40-60$ & $1,7 \mathrm{~d} \mathrm{~A}$ & $1,7 \mathrm{c} \mathrm{A}$ & $1,3 \mathrm{c} \mathrm{A}$ & $1.8 \mathrm{~b} \mathrm{~A}$ \\
& $1,7 \mathrm{~d} \mathrm{~A}$ & $1.5 \mathrm{c} \mathrm{A}$ & $0.9 \mathrm{c} \mathrm{A}$ & $0.6 \mathrm{~b} \mathrm{~A}$
\end{tabular}

DMS (profundidade dentro de manejo) $=2.06$

DMS (manejo dentro de profundidade) $=2,30$

'Médias seguidas da mesma letra, minúscula na coluna e maiúscula na horizontal, não diferem ao nivel de $\mathrm{P}=0,05$ pelo teste de Tukey.

Apêndice 16. Efeito do manejo do solo sobre a distribuição do $\mathrm{Mn}$, em $\mathrm{mg} / \mathrm{L}$ no perfil do solo, após a colheita do arroz.

\begin{tabular}{lllll}
\hline $\begin{array}{c}\text { Profundidade } \\
(\mathrm{cm})\end{array}$ & \multicolumn{4}{c}{ Manejo do solo } \\
\cline { 2 - 5 } $0-5$ & $91,0 \mathrm{a} \mathrm{A}$ & $54,7 \mathrm{a} \mathrm{BC}$ & $66.5 \mathrm{a} \mathrm{B}$ & $45.7 \mathrm{a} \mathrm{C}$ \\
$5-10$ & $56,0 \mathrm{~b} \mathrm{~A}$ & $46,7 \mathrm{a} \mathrm{A}$ & $47,5 \mathrm{~b} \mathrm{~A}$ & $47.2 \mathrm{a} \mathrm{A}$ \\
$10-20$ & $54,2 \mathrm{bc} \mathrm{A}$ & $53,7 \mathrm{a} \mathrm{A}$ & $41,0 \mathrm{bc} \mathrm{A}$ & $41,5 \mathrm{a} \mathrm{A}$ \\
$20-40$ & $53,5 \mathrm{bc} \mathrm{A}$ & $35,7 \mathrm{~b} \mathrm{AB}$ & $31,2 \mathrm{bc} \mathrm{B}$ & $34.7 \mathrm{a} \mathrm{B}$ \\
$40-60$ & $38,0 \mathrm{c} \mathrm{A}$ & $26,2 \mathrm{~b} \mathrm{~A}$ & $25.5 \mathrm{c} \mathrm{A}$ & $26.5 \mathrm{~b} \mathrm{~A}$ \\
\hline
\end{tabular}

DMS (profundidade dentro de manejo) $=16.74$

DMS (manejo dentro de profundidade) $=18.35$

'Médias seguidas da mesma letra. minúscula na coluna e maiúscula na horizontal. não diferem ao nivel de $\mathrm{P}=0,05$ pelo teste de Tukey. 
Apêndice 17. Efeito do manejo do solo sobre a distribuição da matéria orgânica, em $\mathrm{g} / \mathrm{kg}$, no perfil do solo, após a colheita do arroz.

\begin{tabular}{lcccc}
\hline $\begin{array}{c}\text { Profundidade } \\
(\mathrm{cm})\end{array}$ & \multicolumn{4}{c}{ Manejo do solo } \\
\cline { 2 - 5 } $0-5$ & $33,5 \mathrm{a} \mathrm{A}$ & $29,8 \mathrm{a} \mathrm{A}$ & $30,3 \mathrm{a} \mathrm{A}$ & $24,8 \mathrm{a} \mathrm{B}$ \\
$5-10$ & $25,0 \mathrm{~b} \mathrm{~A}$ & $23,0 \mathrm{~b} \mathrm{~A}$ & $23,3 \mathrm{~b} \mathrm{~A}$ & $23,8 \mathrm{a} \mathrm{A}$ \\
$10-20$ & $23,3 \mathrm{~b} \mathrm{~A}$ & $21,3 \mathrm{~b} \mathrm{~A}$ & $20,0 \mathrm{~b} \mathrm{~A}$ & $22,3 \mathrm{a} \mathrm{A}$ \\
$20-40$ & $18,3 \mathrm{c} \mathrm{A}$ & $16,0 \mathrm{c} \mathrm{A}$ & $16,3 \mathrm{c} \mathrm{A}$ & $18,8 \mathrm{~b} \mathrm{~A}$ \\
$40-60$ & $13.3 \mathrm{~d} \mathrm{~A}$ & $11.3 \mathrm{c} \mathrm{A}$ & $13.0 \mathrm{c} \mathrm{A}$ & $14.8 \mathrm{c} \mathrm{A}$
\end{tabular}

DMS (profundidade dentro de manejo) $=3.72$

DMS (manejo dentro de profundidade) $=3.91$

'Médias seguidas da mesma letra, minúscula na coluna e maiúscula na horizontal, não diferem ao nivel de $P=0.05$ pelo teste de Tukey.

Apêndice 18. Efeito do manejo do solo e da adubação sobre o acúmulo de $\mathrm{B}$, em $\mathrm{mg} / \mathrm{L}$, nas folhas de milho.

\begin{tabular}{ccccc}
\hline \multirow{2}{*}{ Adubação } & \multicolumn{4}{c}{ Manejo do solo } \\
\cline { 2 - 5 } T & PD & GA & EP & AP \\
To & $14.7 \mathrm{a} \mathrm{A}$ & $14.0 \mathrm{a} \mathrm{A}$ & $12.7 \mathrm{a} \mathrm{A}$ & $9.2 \mathrm{~b} \mathrm{~B}$ \\
Eg & $13.5 \mathrm{a} \mathrm{AB}$ & $12.0 \mathrm{a} \mathrm{B}$ & $15.0 \mathrm{a} \mathrm{A}$ & $9.5 \mathrm{ab} \mathrm{B}$ \\
DMS (Adubação dentro de manejo) & $=3.02$ & $13.0 \mathrm{a} \mathrm{A}$ & $12.5 \mathrm{a} \mathrm{A}$ \\
\hline DMS (manejo dentro de adubação) & $=2.77$ & & \\
\hline
\end{tabular}

'Médias seguidas da mesma letra. minúscula na coluna e maiúscula na horizontal, não diferem ao nivel de $\mathrm{P}=0.05$ pelo teste de Tukey. 
Apêndice 19. Efeito do manejo do solo e da adubação sobre o acúmulo de $\mathrm{Cu}$, em $\mathrm{mg} / \mathrm{L}$, nas folhas de soja.

\begin{tabular}{crrrl}
\hline $\begin{array}{c}\text { Profundidade } \\
(\mathrm{cm})\end{array}$ & \multicolumn{4}{c}{ Manejo do solo $^{1}$} \\
\cline { 2 - 5 } & \multicolumn{1}{c}{$\mathrm{PD}$} & $\mathrm{GA}$ & \multicolumn{1}{c}{$\mathrm{EP}$} \\
\hline $\mathrm{T}$ & $9,0 \mathrm{AB}$ & $7,2 \mathrm{a} \mathrm{B}$ & $10.5 \mathrm{a} \mathrm{A}$ & $9,2 \mathrm{ab} \mathrm{A}$ \\
To & $10,0 \mathrm{a} \mathrm{A}$ & $7,2 \mathrm{a} \mathrm{B}$ & $8.0 \mathrm{~b} \mathrm{~B}$ & $9,7 \mathrm{a} \mathrm{AB}$ \\
$\mathrm{Eg}$ & $9,0 \mathrm{a} \mathrm{B}$ & $7,5 \mathrm{a} \mathrm{B}$ & $11.2 \mathrm{a} \mathrm{A}$ & $8.0 \mathrm{~b} \mathrm{~B}$ \\
\hline
\end{tabular}

DMS (profundidade dentro de manejo) $=1.51$

DMS (manejo dentro de profundidade) $=1.76$

'Médias seguidas da mesma letra, minúscula na coluna e maiúscula na horizontal, não diferem ao nivel de $\mathrm{P}=0,05$ pelo teste de Tukey.

Apêndice 20. Efeito do manejo do solo e da adubação sobre o acúmulo de B, em mg/L, nas folhas de soja.

\begin{tabular}{ccccl}
\hline $\begin{array}{c}\text { Profundidade } \\
(\mathrm{cm})\end{array}$ & \multicolumn{4}{c}{ Manejo do solo } \\
\cline { 2 - 5 } & $31,5 \mathrm{a} \mathrm{B}$ & $29,0 \mathrm{a} \mathrm{B}$ & $37.5 \mathrm{ab} \mathrm{A}$ & $32,0 \mathrm{a} \mathrm{AB}$ \\
T & $34.0 \mathrm{a} \mathrm{B}$ & $32,5 \mathrm{a} \mathrm{B}$ & $39.0 \mathrm{a} \mathrm{A}$ & $30,5 \mathrm{a} \mathrm{B}$ \\
Eg & $31,0 \mathrm{a} \mathrm{A}$ & $29.5 \mathrm{a} \mathrm{A}$ & $32.0 \mathrm{~b} \mathrm{~A}$ & $34,5 \mathrm{a} \mathrm{A}$ \\
\hline
\end{tabular}

DMS (profundidade dentro de manejo) $=5.19$

DMS (manejo dentro de profundidade) $=5.95$

\footnotetext{
'Médias seguidas da mesma letra, minúscula na coluna e maiúscula na horizontal, não diferem ao nivel de $\mathrm{P}=0.05$ pelo teste de Tukey.
} 
Apêndice 21. Efeito do manejo do solo e da adubação sobre o acúmulo de $\mathrm{N}$, em \%, nas folhas de feijão.

\begin{tabular}{ccccc}
\hline $\begin{array}{c}\text { Profundidade } \\
(\mathrm{cm})\end{array}$ & $\mathrm{PD}$ & $\mathrm{GA}$ & $\mathrm{EP}$ & $\mathrm{AP}$ \\
\cline { 2 - 5 } T & $4,6 \mathrm{a} \mathrm{AB}$ & $4.3 \mathrm{a} \mathrm{B}$ & $4,8 \mathrm{a} \mathrm{A}$ & $4,6 \mathrm{a} \mathrm{AB}$ \\
To & $4,8 \mathrm{a} \mathrm{A}$ & $4,9 \mathrm{a} \mathrm{A}$ & $4,7 \mathrm{a} \mathrm{A}$ & $4,9 \mathrm{a} \mathrm{A}$ \\
Eg & $4.3 \mathrm{a} \mathrm{A}$ & $4,6 \mathrm{a} \mathrm{A}$ & $4,7 \mathrm{a} \mathrm{A}$ & 4,7 a A \\
\hline
\end{tabular}

DMS (profundidade dentro de manejo) $=1,20$

DMS (manejo dentro de profundidade) $=0,40$

'Médias seguidas da mesma letra, minúscula na coluna e maiúscula na horizontal, não diferem ao nivel de $\mathrm{P}=0,05$ pelo teste de Tukey'. 


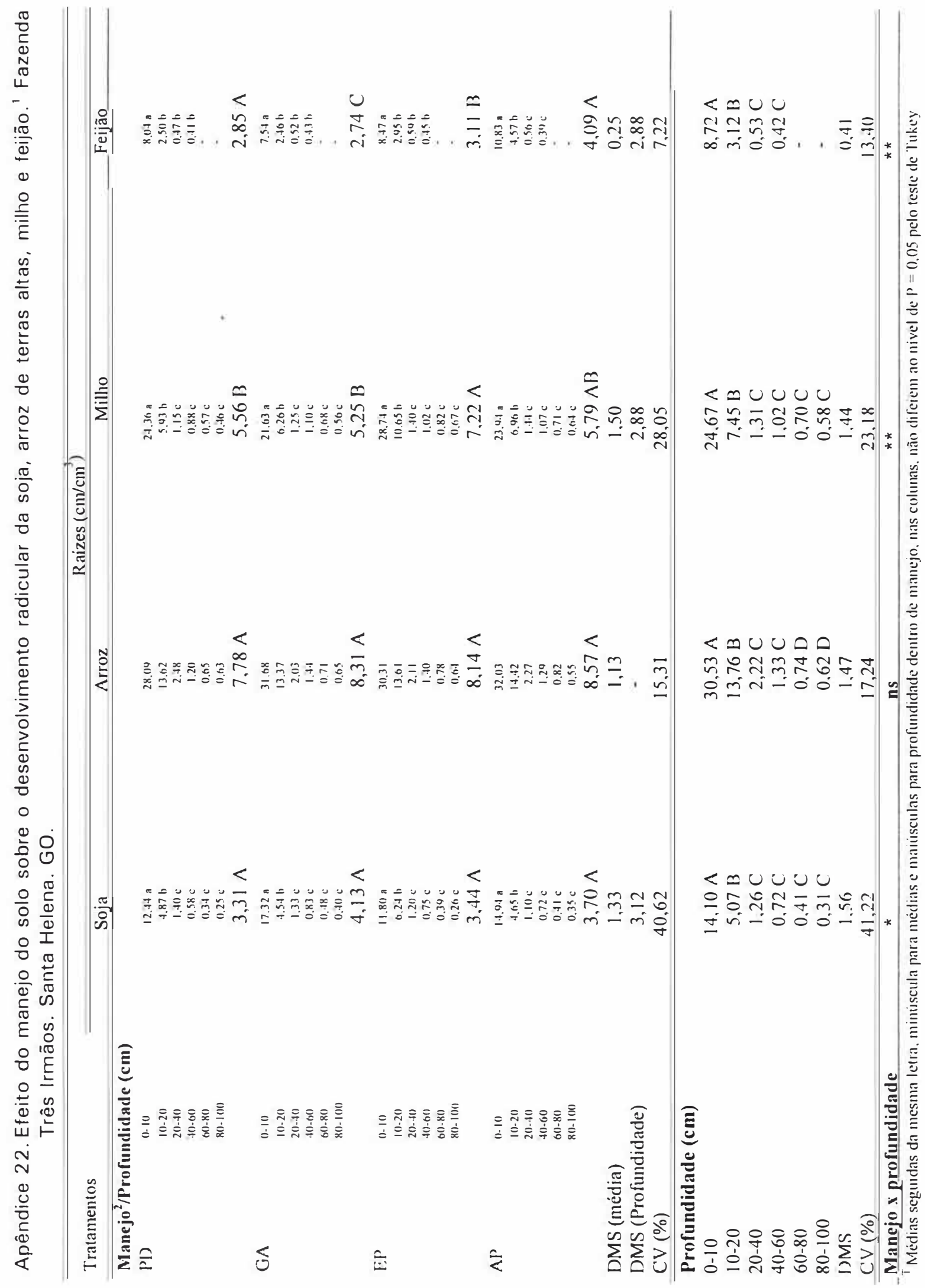




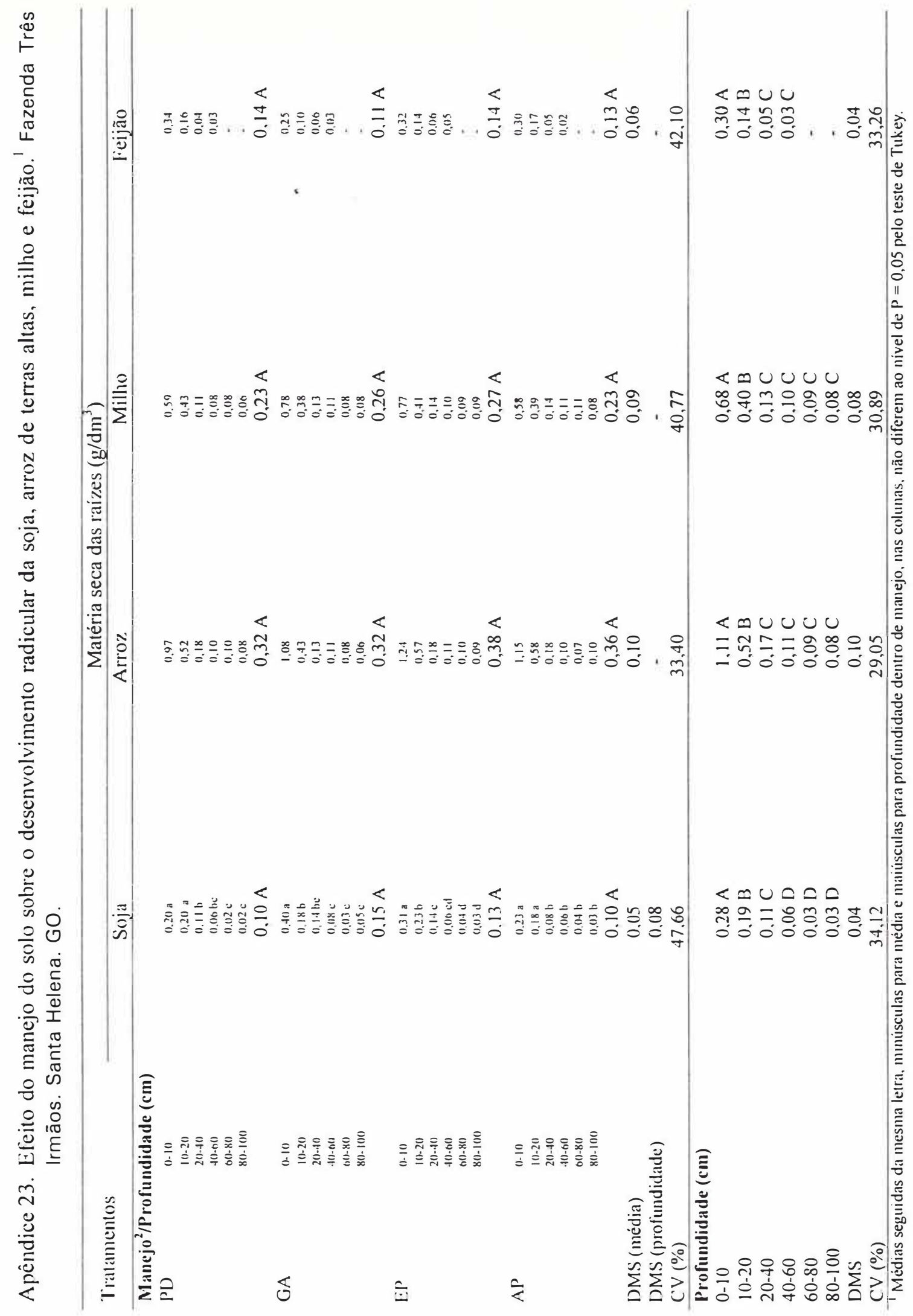


Apêndice 24. Efeito do manejo do solo sobre a distribuição do sistema radicular do milho, em $\mathrm{cm} / \mathrm{cm}^{3}$ no perfil do solo.

\begin{tabular}{|c|c|c|c|c|}
\hline \multirow{2}{*}{$\begin{array}{l}\text { Profundidade } \\
\text { (cm) }\end{array}$} & \multicolumn{4}{|c|}{ Manejo do solo } \\
\hline & $\mathrm{PD}$ & GA & $\mathrm{EP}$ & AP \\
\hline $0-5$ & 24,36 a B & 21,63 a C & 28.74 a $\mathrm{A}$ & 23,94 a BC \\
\hline $5-10$ & $5.93 \mathrm{~b} \mathrm{~B}$ & $6.27 \mathrm{~b} \mathrm{~B}$ & $10,65 \mathrm{~b} \mathrm{~A}$ & 6.96 b B \\
\hline $10-20$ & $1,15 \mathrm{c} \mathrm{A}$ & $1.25 \mathrm{c} \mathrm{A}$ & $1,40 \mathrm{c} \mathrm{A}$ & $1,44 \mathrm{c} \mathrm{A}$ \\
\hline $20-40$ & 0,89 с $A$ & $1,10 \mathrm{c} \mathrm{A}$ & 1,02 c $\mathrm{A}$ & 1,07 c A \\
\hline $40-60$ & 0,57 c A & $0,68 \mathrm{c} \mathrm{A}$ & 0,82 с A & $0,71 \subset \mathrm{A}$ \\
\hline $80-100$ & 0.46 c A & $0.56 \mathrm{c} \mathrm{A}$ & 0.67 с A & $0.64 \mathrm{c} \mathrm{A}$ \\
\hline
\end{tabular}

DMS (profundidade dentro de manejo) $=2.88$

DMS (manejo dentro de profundidade) $=2.67$

'Médias seguidas da mesma letra, minúscula nas colunas e maiúsculas na horizontal, não diferem ao nível de $\mathrm{P}=0,05$ pelo teste de Tukey.

Apêndice 25. Efeito do manejo do solo sobre a distribuição do sistema radicular da soja, em $\mathrm{cm} / \mathrm{cm}^{3}$ no perfil do solo.

\begin{tabular}{lcccc}
\hline $\begin{array}{c}\text { Profundidade } \\
(\mathrm{cm})\end{array}$ & $\mathrm{PD}$ & $\mathrm{GA}$ & $\mathrm{EP}$ & $\mathrm{AP}$ \\
\cline { 2 - 5 } $0-5$ & $12,44 \mathrm{a} \mathrm{BC}$ & $17.23 \mathrm{a} \mathrm{A}$ & $11.80 \mathrm{a} \mathrm{C}$ & $14,95 \mathrm{a} \mathrm{AB}$ \\
$5-10$ & $4.87 \mathrm{~b} \mathrm{~A}$ & $4.54 \mathrm{~b} \mathrm{~A}$ & $6,24 \mathrm{~b} \mathrm{~A}$ & $4,65 \mathrm{~b} \mathrm{~A}$ \\
$10-20$ & $1,40 \mathrm{c} \mathrm{A}$ & $1.33 \mathrm{c} \mathrm{A}$ & $1.20 \mathrm{c} \mathrm{A}$ & $1,10 \mathrm{c} \mathrm{A}$ \\
$20-40$ & $0.58 \mathrm{c} \mathrm{A}$ & $0.83 \mathrm{c} \mathrm{A}$ & $0.75 \mathrm{c} \mathrm{A}$ & $0.72 \mathrm{c} \mathrm{A}$ \\
$40-60$ & $0.34 \mathrm{c} \mathrm{A}$ & $0.48 \mathrm{c} \mathrm{A}$ & $0.39 \mathrm{c} \mathrm{A}$ & $0.41 \mathrm{c} \mathrm{A}$ \\
$80-100$ & $0.25 \mathrm{c} \mathrm{A}$ & $0.41 \mathrm{c} \mathrm{A}$ & $0.26 \mathrm{c} \mathrm{A}$ & $0.35 \mathrm{c} \mathrm{A}$
\end{tabular}

DMS (profundidade dentro de manejo) $=3.12$

DMS (manejo dentro de profundidade) $=2.91$

${ }^{1}$ Médias seguidas da mesma letra, minúscula nas colunas e maiúsculas na horizontal, não diferem ao nivel de $\mathrm{P}=0,05$ pelo teste de Tukey. 
Apêndice 26. Efeito do manejo do solo sobre a distribuição do sistema radicular do feijão, em $\mathrm{cm} / \mathrm{cm}^{3}$, no perfil do solo.

\begin{tabular}{ccccc}
\hline $\begin{array}{c}\text { Profundidade } \\
(\mathrm{cm})\end{array}$ & \multicolumn{4}{c}{ Manejo do solo } \\
\cline { 2 - 5 } & PD & GA & EP & AP \\
\hline $0-5$ & $8,04 \mathrm{a} \mathrm{BC}$ & $7,54 \mathrm{a} \mathrm{C}$ & $8,47 \mathrm{a} \mathrm{B}$ & $10,83 \mathrm{a} \mathrm{A}$ \\
$10-20$ & $2,50 \mathrm{~b} \mathrm{~B}$ & $2,46 \mathrm{~b} \mathrm{~B}$ & $2,95 \mathrm{~b} \mathrm{~B}$ & $4,57 \mathrm{~b} \mathrm{~A}$ \\
$20-40$ & $0,47 \mathrm{c} \mathrm{A}$ & $0,52 \mathrm{c} \mathrm{A}$ & $0.59 \mathrm{c} \mathrm{A}$ & $0,56 \mathrm{c} \mathrm{A}$ \\
$40-60$ & $0,41 \mathrm{c} \mathrm{A}$ & $0,43 \mathrm{c} \mathrm{A}$ & $0.45 \mathrm{c} \mathrm{A}$ & $0.39 \mathrm{c} \mathrm{A}$
\end{tabular}

DMS (profundidade dentro de manejo) $=2,88$

DMS (manejo dentro de profundidade) $=2.67$

'Médias seguidas da mesma letra. minúscula nas colunas e maiúsculas na horizontal. não diferem ao nível de $\mathrm{P}=0.05$ pelo teste de Tukey.

Apêndice 27. Efeito do manejo do solo e da adubação sobre a massa de 100 grãos (g) na cultura do milho.

\begin{tabular}{|c|c|c|c|c|}
\hline \multirow{2}{*}{ Adubação } & \multicolumn{4}{|c|}{ Manejo do solo } \\
\hline & $\mathrm{PD}$ & GA & EP & AP \\
\hline $\mathrm{T}$ & $23.70 \mathrm{~b} \mathrm{AB}$ & 24,51 a $\mathrm{AB}$ & $23.41 \mathrm{c} \mathrm{B}$ & 24,96 b A \\
\hline To & 24.63 a A & 24,51 a A & 24.28 b A & $25,44 \mathrm{ab} A$ \\
\hline $\mathrm{Eg}$ & 24.88 a A & 24,94 a $\mathrm{A}$ & 25.57 a A & 25.99 a $\mathrm{A}$ \\
\hline $\begin{array}{l}\text { DMS (adul } \\
\text { DMS (man }\end{array}$ & $\begin{array}{l}\text { o de manejo) } \\
\text { de adubação) }\end{array}$ & $\begin{array}{l}=0.79 \\
=1.31\end{array}$ & & \\
\hline
\end{tabular}

'Médias seguidas da mesma letra. minúscula na coluna e maiúscula na horizontal. nào diferem ao nível de $\mathrm{P}=0.05$ pelo teste de Tukey. 
Apêndice 28. Efeito do manejo do solo e da adubação sobre a população final de plantas de soja, em número de plantas por hectare.

\begin{tabular}{ccccc}
\hline \multirow{2}{*}{ Adubação } & \multicolumn{4}{c}{ Manejo do solo } \\
\cline { 2 - 5 } & \multicolumn{1}{c}{ PD } & \multicolumn{1}{c}{ GA } & \multicolumn{1}{c}{ EP } & AP \\
\hline T & 384720 a A & 373030 a A & 374072 a A & 371294 a A \\
To & 381942 a A & 365391 a A & 360646 ab A & 353470 a A \\
Eg & 290855 b C & 344790 a AB & 324188 b BC & 365276 a A \\
\hline
\end{tabular}

DMS (profundidade dentro de manejo) $=45699$

DMS (manejo dentro de profundidade) $=39607$

'Médias seguidas da mesma letra. minúscula na coluna e maiúscula na horizontal, não diferem ao nivel de $P=0,05$ pelo teste de Tukey.

Apêndice 29. Efeito do manejo do solo e da adubação sobre a massa de 100 grãos (g) de soja.

\begin{tabular}{ccccc}
\hline \multirow{2}{*}{ Adubação } & \multicolumn{5}{c}{ Manejo do solo } \\
\cline { 2 - 5 } & PD & GA & EP & AP \\
\hline T & $17.34 \mathrm{~b} \mathrm{~B}$ & $18.61 \mathrm{a} \mathrm{A}$ & $18.85 \mathrm{a} \mathrm{A}$ & $17.52 \mathrm{~b} \mathrm{~B}$ \\
To & $18.52 \mathrm{a} \mathrm{A}$ & $18.28 \mathrm{a} \mathrm{A}$ & $18.59 \mathrm{a} \mathrm{A}$ & $18,88 \mathrm{a} \mathrm{A}$ \\
Eg & $18.75 \mathrm{a} \mathrm{B}$ & $18.12 \mathrm{a} \mathrm{B}$ & $18.11 \mathrm{a} \mathrm{B}$ & $19.88 \mathrm{a} \mathrm{A}$ \\
\hline
\end{tabular}

DMS (profundidade dentro de manejo) $=1,10$

DMS (manejo dentro de profundidade) $=1.06$

${ }^{1}$ Médias seguidas da mesma letra. minúscula na coluna e maiúscula na horizontal, não diferem ao nivel de $\mathrm{P}=0,05$ pelo teste de Tukey. 
Apêndice 30. Efeitos do manejo do solo e da profundidade de adubação sobre o rendimento do feijoeiro, cv. Perola. Fazenda Três Irmãos. Santa Helena. GO.'

\begin{tabular}{|c|c|c|}
\hline \multirow{2}{*}{$\begin{array}{l}\text { Profundidade } \\
\text { de adubação }(\mathrm{cm})\end{array}$} & \multicolumn{2}{|c|}{ Rendimento (kg/ha) } \\
\hline & Plantio direto & Aiveca \\
\hline Sem adubo & 2499 a & 2899 a \\
\hline 5 & 2629 a & $2520 \mathrm{~b}$ \\
\hline 10 & $2846 \mathrm{a}$ & $3087 \mathrm{a}$ \\
\hline Média & 2658 & 2835 \\
\hline DMS & \multicolumn{2}{|c|}{376.0} \\
\hline CV (\%) & \multicolumn{2}{|c|}{11,26} \\
\hline Manejo x prof. adubação & \multicolumn{2}{|c|}{ ns } \\
\hline \multicolumn{3}{|c|}{ 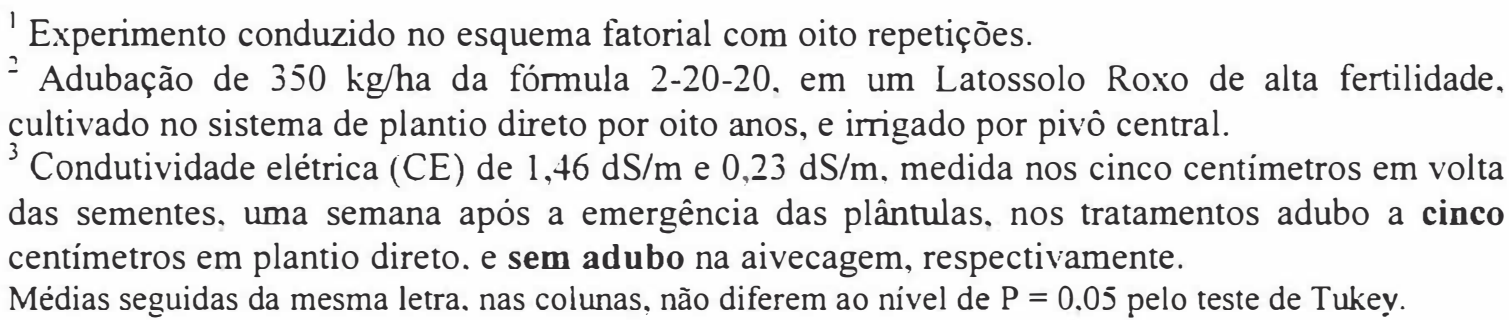 } \\
\hline
\end{tabular}


Apêndice 31. Efeito do espaçamento e da densidade de semeadura sobre o rendimento de dois cultivares de feijão. Fazenda Três Irmãos. Santa Helena. GO.'

\begin{tabular}{|c|c|c|c|}
\hline \multirow{2}{*}{$\begin{array}{l}\text { Espaçamento } \\
(\mathrm{cm})\end{array}$} & \multirow{2}{*}{$\begin{array}{l}\text { Densidade } \\
\text { (plantas/m) }\end{array}$} & \multicolumn{2}{|c|}{ Rendimento $(\mathrm{kg} / \mathrm{ha})^{2}$} \\
\hline & & Jalo Precoce ${ }^{3}$ & Pérola ${ }^{4}$ \\
\hline \multirow[t]{5}{*}{30} & 6 & $3038(6,3)$ & $\cdot$ \\
\hline & 9 & $3170(9,2)$ & - \\
\hline & 12 & $3490(11,9)$ & - \\
\hline & 15 & $3758(14,0)$ & - \\
\hline & & $3364 a b$ & - \\
\hline \multirow[t]{5}{*}{40} & 6 & $3390(6,7)$ & $3851(6,2)$ \\
\hline & 9 & $2980(9,3)$ & $4308(9,1)$ \\
\hline & 12 & $3715(11,9)$ & $5005(11,7)$ \\
\hline & 15 & $3817(14,0)$ & $4784(13,7)$ \\
\hline & & 3475 a & 4487 a \\
\hline \multirow[t]{5}{*}{50} & 6 & $2432(6,4)$ & $3761(5,9)$ \\
\hline & 9 & $3134(9,6)$ & $4270(8,6)$ \\
\hline & 12 & $3100(12,0)$ & $4168(11,5)$ \\
\hline & 15 & $3497(14,1)$ & $4639(13,3)$ \\
\hline & & 3041 bc & 4210 a \\
\hline \multirow[t]{5}{*}{60} & 6 & $2566(6,2)$ & $3617(5,7)$ \\
\hline & 9 & $2763(9,4)$ & $4284(8,8)$ \\
\hline & 12 & $2868(11,8)$ & $4043(10,6)$ \\
\hline & 15 & $3162(13,8)$ & $4810(12,7)$ \\
\hline & & $2840 \mathrm{c}$ & 4189 a \\
\hline \multirow[t]{5}{*}{70} & 6 & - & $3510(5,8)$ \\
\hline & 9 & - & $3623(8,3)$ \\
\hline & 12 & - & $3630(11,2)$ \\
\hline & 15 & - & $3813(12,1)$ \\
\hline & & - & $3644 \mathrm{~b}$ \\
\hline \multirow[t]{4}{*}{ Média } & 6 & $2856 b$ & $3685 b$ \\
\hline & 9 & $3012 b$ & $4121 a b$ \\
\hline & 12 & $3293 a b$ & $4211 a$ \\
\hline & 15 & 3559 a & $4512 a$ \\
\hline \multirow{2}{*}{\multicolumn{2}{|c|}{$\begin{array}{l}\text { DMS } \\
\text { CV }(\%)\end{array}$}} & \multicolumn{2}{|c|}{458,2} \\
\hline & & \multicolumn{2}{|c|}{13,5} \\
\hline \multicolumn{4}{|c|}{$\begin{array}{l}\text { Experimento conduzido no esquema fatorial e delineamento de blocos ao acaso, com quatro } \\
\text { repetições. } \\
2 \text { Adubação de } 350 \mathrm{~kg} / \mathrm{ha} \text { da fórmula } 2-20-20 \text {, em um Latossolo Roxo de alta fertilidade. Semeadura } \\
\text { realizada em } 16 / 06 / 97 \text {, sendo irrigado por aspersão com autopropelido. } \\
{ }^{3} \text { Ciclo à colheita de } 73 \text { dias, tipo } 11 \text {, hábito de crescimento indeterminado. } \\
\text { ' Ciclo à colheita de } 90 \text { dias, tipo III, hábito de crescimento indeterminado. } \\
5 \text { Em parênteses, população final de plantas } / \mathrm{m} \text {. } \\
\text { Médias seguidas da mesma letra, nas colunas, não diferem ao nivel de } P=0,05 \text {, pelo teste de } \\
\text { Tukey. }\end{array}$} \\
\hline
\end{tabular}



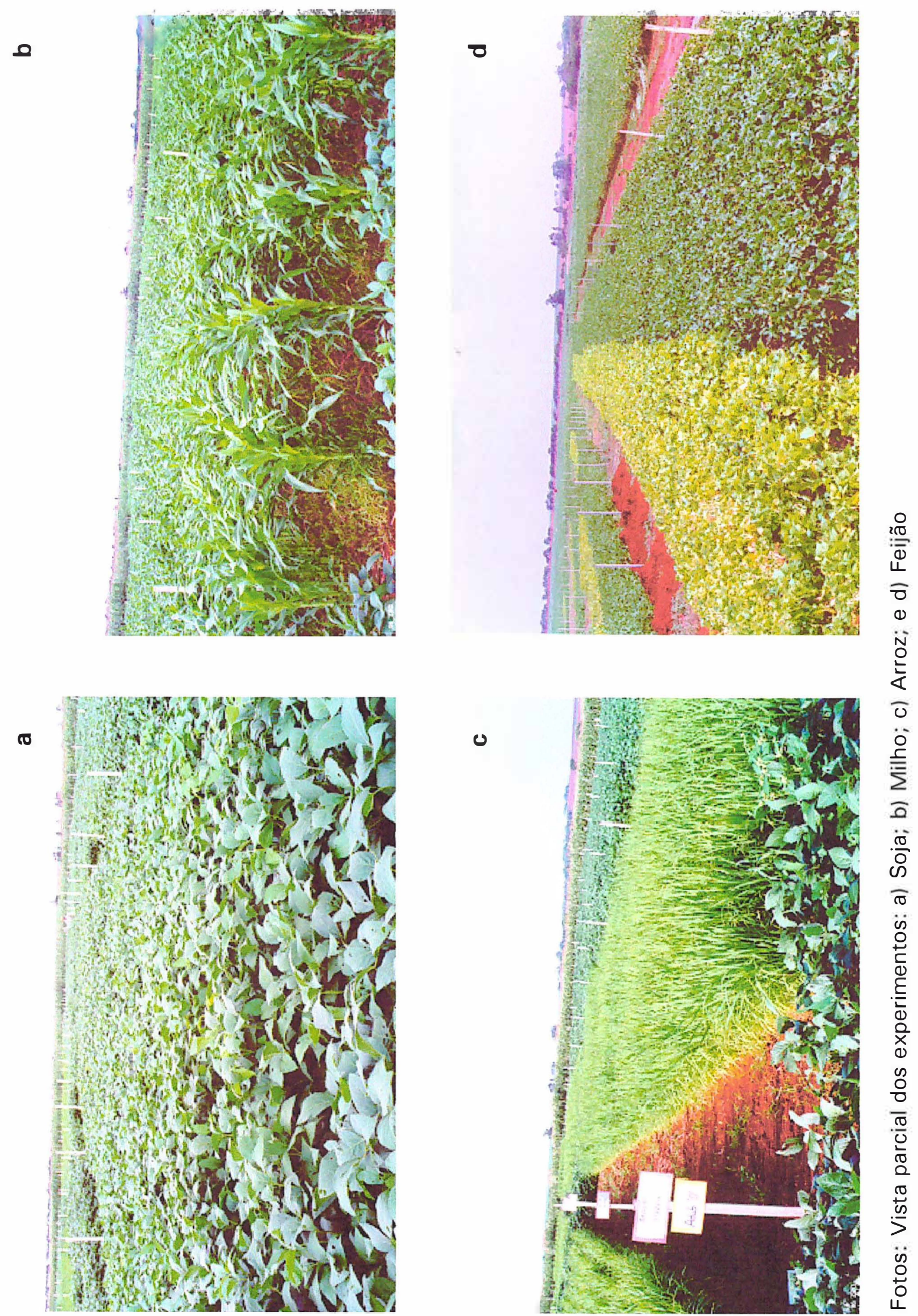